


\section{PUBLISHER}

The Swedish Archaeological Society \& Nordic Academic Press

\section{EDITORS}

Martin Hansson \& Anna Källén

\section{THIS VOLUME IS PUBLISHED WITH GRANTS FROM}

The Swedish Research Council

\section{SUBSCRIPTION}

Current Swedish Archaeology is published in one annual volume. Price per volume excl. postage: SEK 200 for individuals, SEK 400 for institutions (who will receive two copies). Subscription orders should be sent to:

Current Swedish Archaeology

c/o Förlagssystem $\mathrm{AB}$

Box 30104

IO4 25 STOCKHOLM

Tel: o8-737 8666

Email: csa@forlagssystem.se

\section{WEB}

www.arkeologiskasamfundet.se/csa

www.nordicacademicpress.com

(C) 20I0 The Swedish Archaeological Society

Nordic Academic Press

Box I 206

22 I 05 LUND

info@nordicacademicpress.com

English revised by Laura Wrang

Graphic design: Lönegård \& Co

Boat illustration on cover: Inger Kåberg

Printed by Trydells, Laholm

ISSN I IO2-7355 

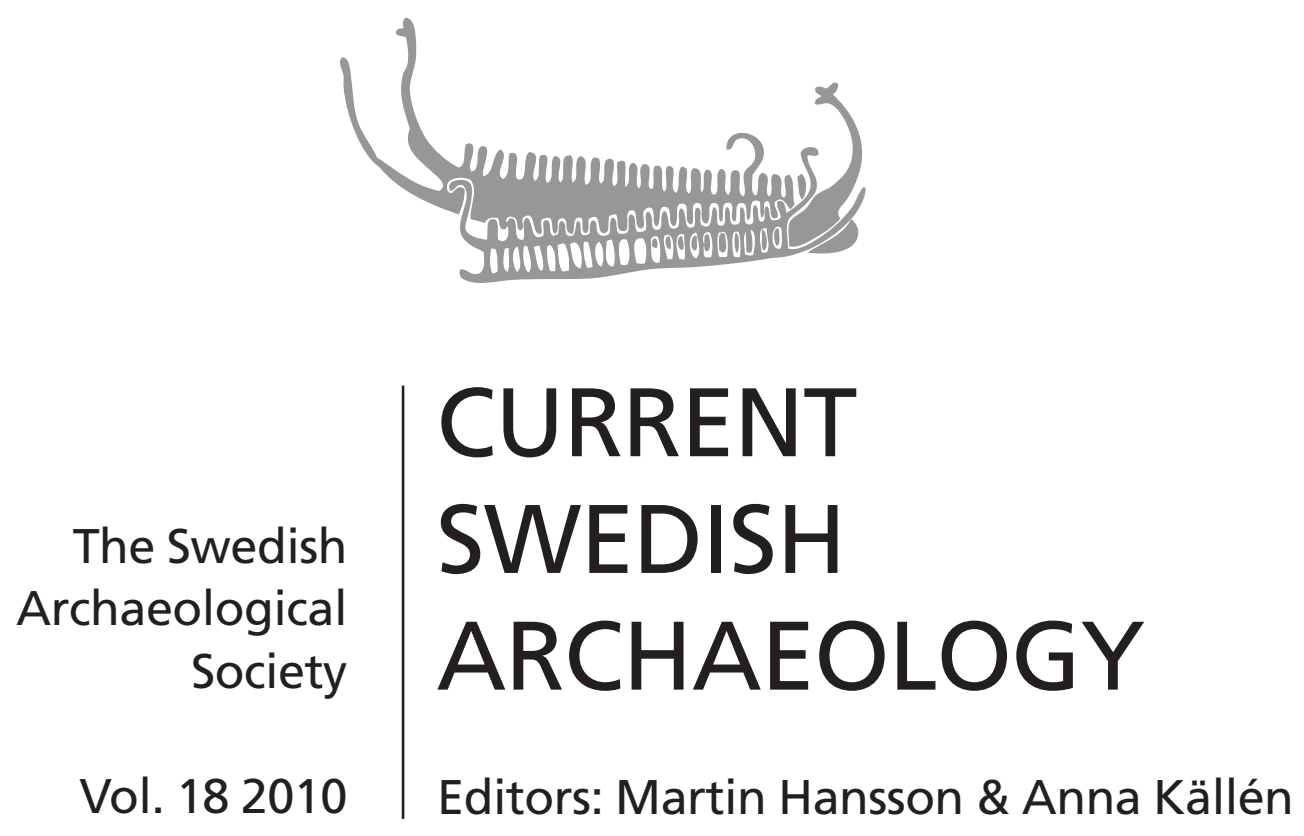


\section{Contents}

Editorial

8

\section{Keynote}

\section{Carolina Andersson, Agneta Lagerlöf \& Eva Skyllberg:}

Assessing and measuring: On quality in development-led archaeology ........ I I

\section{Håkon Glørstad:}

Comments on quality from the ivory tower

\section{Joakim Goldhahn:}

The key chain of archaeology is not stronger than its weakest link

Nathan Schlanger \& Kai Salas Rossenbach:

'Quality' advice from French preventive archaeology

\section{Fredrik Stjernberg:}

Comments on 'Assessing and measuring: On quality in development-led archaeology'

\section{Carolina Andersson, Agneta Lagerlöf \& Eva Skyllberg:}

Reply to comments on the article 'Assessing and measuring: On quality in development-led archaeology’

\section{Articles}

\section{Mattias Ahlbeck \& Alexander Gill:}

The essence of stone. Making axes during the late mesolithic in

Södertörn in east central Sweden

\section{Richard Bradley, Peter Skoglund \& Joakim Wehlin:}

Imaginary vessels in the late bronze age of Gotland and south Scandinavia:

Ship settings, rock carvings and decorated metalwork

\section{Magdalena Forsgren:}

The divine appearance of Härn. Determining the identity of a

Bronze Age metal hoard

\section{Olle Heimer:}

The mythical forge and the holy chapel. From paganism to Christianity at the manorial farm in Lockarp, Scania 


\section{Ola W. Jensen:}

The art of valuating a heritage: From a Swedish management perspective with past and present examples

\section{Ola Kyhlberg:}

The great masterpiece. The Rök stone and its maker

\section{Marta Lindeberg:}

Forging history. Spade-shaped currency bars, history and identity in central Norrland

\section{Ola Magnell \& Elisabeth Iregren:}

Veitstu hvé blóta skal? The Old Norse blót in the light of osteological remains from Frösö church, Jämtland, Sweden

\section{Ylva Sjöstrand:}

Product or production. On the accumulative aspect of rock art at

Nämforsen, northern Sweden

\section{Reviews \& notices}

\section{Björn Nilsson:}

Review: Breaking and making bodies and pots: Material and ritual practices in Sweden in the third millennium BC

Längs med Hjälmarens stränder och förbi - relationen mellan den gropkeramiska kulturen och båtyxekulturen

\section{Anna Lihammer:}

Review: Det gamla Uppsala. Berättelser \& metamorfoser kring en alldeles särskild plats

\section{Susanne Thedéen:}

Review: Sveriges historia I 3000 f $\mathrm{Kr}-600$ e $\mathrm{Kr}$

Sveriges historia $600-\mathrm{I} 350$

\section{Lars Amréus:}

History of Sweden 282

\section{Tore Artelius:}

A comment on recent trends in the prerequisites for Swedish development-led archaeology

\section{Erik Rosengren:}

MARK, the professional association of museum archaeologists, and a little about contract archaeology in company form 



\section{The Swedish Archaeological Society}

In 1947 the statutory meeting for the Swedish Archaeological Society took place at the Museum of National Antiquities. The Society is a common body for professional Swedish archaeologists, regardless of specialty. According to the statutes the purpose of the Society is to further Swedish archaeological research and to support this research by granting scholarships. The Society shall especially take care of the vocational interest of the archaeologists. This task shall be carried out by taking part in the public debate, by influencing the public opinion, and by being a body to which proposed measures are submitted for consideration. The Society arranges discussions and seminars on different archaeological topics, and every second year the Society holds a thematic meeting for Swedish archaeologists.

In 1993 the annual journal Current Swedish Archaeology began to be issued. The journal has since then contained articles mirroring current archaeological research and theoretical trends. The Society's board has eleven members from universities, museums and archaeological institutions in various parts of Sweden. Tore Artelius, from the Department for Archaeological Excavations at the Swedish National Heritage Board, is the present chairman. 


\section{Editorial}

The eighteenth volume of Current Swedish Archaeology has landed! In this volume we retain the tripartite contents introduced in the last volume and begin with a keynote debate on the concept of quality in development-led archaeology. A complement to the more theoretical discussion on cultural evolution in the last volume, this debate concerns the everyday reality of many archaeologists working within development-led archaeology in Sweden today. The question of how to define and measure quality in this type of archaeology has been a hot issue for the National Heritage Board and the county administrative boards in Sweden over the last couple of years, and it was addressed at a special conference in Stockholm in 2009. The keynote article demonstrates that this is an issue of some complexity, and the replies from our four guest commentators show that the discussion has much to gain from the experiences of other national contexts such as Norway and France as well as other academic disciplines such as philosophy. With respect to the larger picture, we think this proves the point we wanted to make by promoting this discussion here: that issues that mainly appear to be relevant for public authorities and heritage administration can also be relevant for the larger field of archaeological research and can benefit from being discussed in academic journals such as CSA.

The nine articles in the second part of the volume reflect the great diversity of themes and approaches in current Swedish archaeology. These articles fit the overall description of CSA and focus on the interpretation of the archaeological record and archaeology as social practice, but at the same time they are very different from each other. Some general themes and trends can, however, be discerned. Two articles (Magnell and Iregren, and Heimer) present new and original materials that offer new interpretational approaches to important themes and 
questions in Scandinavian archaeology. Otherwise it is the presentation of new 'glasses' through which to look at previously known materials that dominates this volume. The six articles that fit this description discuss materials ranging in time from the Stone Age to the Iron Age, and geographically from the north to the south. As a final complement to all these new glasses, Jensen gives us a Swedish historical perspective on the valuation of heritage, in the only paper in this volume to deal specifically with archaeology as social practice.

We are glad to be able to present such a wide variety of current Swedish archaeology, and wish you a pleasant read. Visit our web site (www.arkeologiskasamfundet.se/csa) for news about the ongoing digitalisation of past volumes, and for deadlines and submission guidelines for coming volumes.

This volume will be the last for Martin, who moves on to other important tasks, and we are therefore pleased to welcome Anders Högberg as the new editor who will work together with Anna on the next volume.

Martin Hansson \& Anna Källén, editors 


\section{KEYNOTE}




\section{ASSESSING AND MEASURING}

\section{On quality in development-led archaeology}

Carolina Andersson, Agneta Lagerlöf \& Eva Skyllberg

\begin{abstract}
The concept of quality has become the subject of intensive discussion in almost all aspects of society in recent years and development-led archaeology is no exception. Results showing a lack of quality have been observed both in countries which choose to use systems based on competitive tendering and in those where developmentled archaeology is conducted solely by official institutions. In this article the authors discuss the essential elements for achieving good quality in developmentled archaeology as required by the Swedish Heritage Act. They also discuss how Swedish development-led archaeology can be enhanced and what is needed to achieve and maintain quality.
\end{abstract}

Key words: archaeology, development-led archaeology, quality, the development-led archaeological system, Heritage Conservation Act, KML

The Swedish Heritage Conservation Act (KML) states that development-led archaeology (Sw.uppdragsarkeologi) should be of good quality ('god kvalitet'). But what is meant here by good quality? In recent years the Swedish National Heritage Board has attempted to explain its definition of 'good quality' in development-led archaeology by means of regulations and guidelines. Regardless whether it is a special survey, field evaluation or excavation, assessing the good quality of an archaeological investigation is not easy. Quality is both complex and difficult to determine.

In this article we wish to discuss quality both as a general phenomenon and as a specific aspect of development-led archaeology. We will also present a brief overview of how other European countries organize 
their development-led archaeology and how this influences the qualitative results. With that as a background we will then focus on the development-led archaeological system in Sweden. What does the law say about quality? What are the fundamental elements of the system from a qualitative perspective? We will also discuss the expectations of society at large, that is, the aims of development-led archaeology and its benefit to society. Finally, we will open the door to the future. What can we do to enhance development-led archaeology? What efforts would promote an increase in quality and sustain it?

\section{THE CONCEPT OF 'QUALITY'}

Nowadays we use two different concepts of 'quality'. One (good qual$i t y$ ) is humanistic in its orientation while the other (correct quality) is technological (Sw. god kvalitet, rätt kvalitet, Nationalencyklopedin n.d.). Good quality is often a matter of assessment of, for example, the content of an archaeological report or the result of an archaeological investigation. Correct quality is mainly a matter of procedure and form; for example, that the tender submission document is correctly formulated in accordance with the specifications for development-led archaeology (KRFS 2007:2). Thus, good quality is assessed while correct quality is most often measurable.

The perception of quality, and the body responsible for its assessment, has changed over time. Prior to the Industrial Revolution the (master) craftsman guaranteed the quality of what was produced. Quality was a component of each separate product and the individual served as quality guarantor. In the industrial society quality assurance was instead integral to the production process. It was how it was done that was assessed, by means of, for example, the standards in ISO 9000. Quality meant reproducing the same quality in large numbers.

In our blue collar or information society the idea of quality lies mostly outside the product, in the realm of the user. What is important is who it is that receives a product or service. It is no longer a matter of assessment or measurement. The main focus is now directed to establishing which characteristics are important and who decides the agenda. Thus quality is also related to power, that is, to those deciding what is good. Within development-led archaeology the county administrative boards play a key role, as they are the representatives of society requesting the archaeological knowledge. This role requires not only clarity of communication but also the ability to balance the concerns of the various stakeholders. 


\section{EVERYONE IS TALKING ABOUT QUALITY}

Today, in the early 2 Ist century, quality is more topical than ever. We hear about quality management, quality control and quality assurance. The word 'quality' has become a mantra for progress and success and thereby risks becoming a superficial and hollow term. Its popularity stems perhaps from developments within the service sector, where there is overconfidence in the self-regulating power of the market and a focus on cost to the detriment of individual persons or groups. As previously state-run sectors become privatized and market oriented (for example, electricity, health care, care of the elderly, schools, child care), it becomes apparent that there is considerable risk that the worth of an activity drops if quality is not demanded, controlled and followed up. The significance of quality has thus become more obvious. Today quality is an important criterion both in commissioning and in evaluating a service, and thereby an important tool of competition.

With regard to development-led archaeology, market adaptation has resulted in the commissioner of an archaeological work becoming more precise about what is required, so that it sustains good quality. A further positive effect is that the various actors within development-led archaeology have gained a more professional attitude (precise orders, transparent evaluations, project planning, and quality assurance systems, etc).

The introduction of competition into development-led archaeology has, however, produced a series of negative consequences, especially in those countries in Europe where competition has advanced furthest and where regulations are few or almost nonexistent. One needs to recall the aim behind the whole system, and review the archaeological process, so as to safeguard scientific standards of quality.

Paradoxically, now that an emphasis on quality has entered the competition, the focus on high quality rather than on low price has more or less become a survival strategy for the competing applicants. Within development-led archaeology one must be able to show what good quality at a reasonable price is and what cost-effective development-led archaeology is all about.

\section{A VIEW OF EUROPE}

Intensive community expansion: the I992 Valletta Convention The proposals of the Convention on the protection of the archaeologi- 
cal heritage (European Treaty Series No I43), accepted in Valletta in Malta in I992, have been highly significant for development-led archaeology in Europe. The Valletta Convention came about as a result of the threat to the European cultural heritage from increasing largescale exploitation, decomposition due to environmental factors, and the occurrence of illegal and unscientific excavations.

The Convention stipulated a series of quality-raising measures such as extra legal protection, ensuring that investigations are carried out in a scientific manner, and that sufficient resources are available for financing an investigation. As a result of the Valletta Convention many European countries have legislated that the developer is responsible for the costs of the archaeological investigation caused by the developer's exploitations.

\section{Advances since 1992}

In the early I990s market forces were strong and, braced by the Valletta Convention and developer responsibility for costs, many countries introduced the element of competition into the development-led archaeological arena. Ireland and England were among the first to do so. Free competition was introduced and the developer alone negotiated the archaeological contract. It was considered that the system would in principle be self-regulatory and would not need any statements or binding legalities. No quality assurance systems or follow-up systems were introduced in either country.

Several other countries such as Holland, France and Sweden were influenced by this progress, especially by that in England, but chose to follow suit in varying degrees. In Holland a system similar to the English was introduced but with a detailed quality assurance system which all investigators are forced to follow. In France official institutions carry out all special surveys and field evaluations (a monopoly that is accepted by the EU), while excavations are submitted to competitive tendering. The state also controls the monitoring of the scientific quality. French development-led archaeological activity is strongly linked to academic research, and the state investigation bureau (INRAP) has its own research and development section.

Some countries chose not to introduce competition within development-led archaeology, and have argued that competition does not further good scientific quality. Examples are Hungary, Norway and Denmark. In Denmark and Norway development-led archaeology is exclusively run by the official institutions. It is likened to a research 
project and should therefore be carried out by a museum which undertakes research. Both countries maintain the vital importance of a link between development-led archaeology and research, and museums are therefore commissioned to conduct all development-led archaeological investigations. With the 'Scandinavian model' in mind, Hungary has so far chosen not to introduce competition.

Thus, there are a number of different development-led archaeological systems in Europe. The choice of a system has sometimes been the subject of intensive debate. In France the introduction of competition was preceded by a heated discussion in the media which was followed with great interest by several countries in Europe. France, however, still has a state monopoly alongside competition.

\section{Experience}

It is in countries with systems that are built on competition, to a greater or lesser extent, that the question of quality in development-led archaeology comes to the fore. The problems concerning quality can be summarised as follows:

- Price competition leads to low profitability, which in turn leads to the development-led archaeologists (or their firms) being unable to invest in competence, research or method development.

- Increased distance between development-led archaeology and the universities.

- The activity is viewed primarily as a service for developers, not as a stage in the research process.

- Inadequate financing of reports.

- Inadequate follow-up of the work process and its result.

A serious problem is that investigations tend to be carried out at such low costs that sufficient time is not allowed for report writing, which in turn results in a great amount of unwritten reports, or that reports are of such low quality that the dissemination of knowledge is hampered (see 'grey literature' in Pearce 2008). In the end, the state often has to go in with funds so that the investigation can be completed, or alternatively so that the information gathered can be disseminated (APPAG 2003; Doyle 2008; Pearce 2008; Lüth 2008). In order to guarantee that society will have access to knowledge of the past, several countries such as England and Ireland have thought it necessary for 
the state to take more responsibility for quality aspects and monitor these by means of regulations, guidelines, quality assurance systems, national or regional research programmes, follow-up, and evaluation (e.g. APPAG 2003; University College Dublin and Heritage Council 2006; Expert Advisory Committee, Department of the Environment, Heritage and Local Government Dublin 2008).

Even countries that have not introduced competition have had problems with sustaining scientific quality and with focusing on meaningful generation and dissemination of knowledge. In a recently completed overhaul concerning the generating of knowledge within Danish development-led archaeology, it was established that to divide these investigations among many small museums can be a problem in terms of establishing a dynamic archaeological research atmosphere. In addition there is a need, on a national level, for establishing guidelines and conditions for deeper analysis. Examples of problems in quality encountered in the Danish system include:

- Scientific analysis and publication beyond the basic reports are not included in the commission/tender.

- Considerable distance between development-led archaeology and the universities.

The problem of increased distance to universities and the importance of stimulating cooperation between field archaeologists and the universities has been stressed by among others Adrian Oliver of English Heritage, who partook as an external expert in the overhaul of the Danish archaeological system in 2009 (Oliver 2009). The problem also exists in England and can be linked to the changing role of the universities from both teaching and research institutes to primarily teaching ones. This has also been the case in Sweden where funding to universities is determined mainly by the number of registered students.

\section{The present: the need for quality and quality assurance}

Recently, critical voices have been raised from several countries concerning a present lack of quality or the risk of such, stressing the imperative need for some form of state control over development-led archaeological activity (Willems \& Brandt 2004; Willems \& Van den Dries 2007; Hinton \& Jennings 2007; Demoule 2007).

At the European Association of Archaeologists Conference in 2005 
quality assurance was made one of the themes on account of the ever hardening competitive climate in development-led archaeology (EAA 2005), and in 2008 an extensive session was organized for the exchange of experience and to discuss the effects of the Valletta Convention (EAA 2008). Poland, for example, expressed concern that the outcome there had in fact been quite the opposite to the intentions of the Convention. Representatives of several European countries thought that quality must now be the focus in order to fulfil the aims of development-led archaeology.

In a competitive system the winners of a tender are those who claim to produce the best goods at the best price, which is not necessarily the same as the lowest price. In order for this system to function the buyer must have a primary interest in the goods and be able to assess his quality of the goods. Within development-led archaeology the buyer, in those countries that have free competition, is the developer. In such a market the most important feature that the supplier, i.e. the investigating archaeologists, can compete with, is price. Without well-functioning state regulations, quality assurance systems and qualified monitoring and follow-up, there is a great risk that standards will drop to an unacceptable level. One of the clearest examples of this is the present situation in Ireland (University College Dublin and Heritage Council 2006; Department of the Environment, Heritage and Local Government Dublin 2008). In England the archaeological community stresses the importance of quality assurance of 'process, product and person' (Hinton \& Jennings 2007).

The countries that are uncertain about whether to adopt a competitive system, such as Hungary, wish to begin by building up a good quality assurance system. Uncertainty primarily concerns the fear of jeopardizing the scientific quality (Gábor 2008). There is great consensus among European countries that a development-led archaeological investigation is a scientific process which raises special demands for quality assurance. The major archaeological investigators in England and France (Oxford Archaeology and INRAP) have the support of academic committees of researchers (Oxford) or a research department (INRAP). In Denmark and Norway archaeological councils or researching university museums have been created, which support the central state agency in assessing larger projects, project planning and reports. In Holland there is a state inspector whose job is to follow up and evaluate the quality of development-led archaeology (Van den Dries \& Willems 2007). 
In all development-led archaeological systems, both competitive and non-competitive, there must be a built-in function to ensure quality in terms of both form and content.

\section{A SWEDISH PERSPECTIVE}

\section{Quality and the law}

It is vitally important that binding legal regulations emphasize the importance of standards of good quality in the development-led archaeological process.

The Swedish Heritage Conservation Act (KML) states:'The county administrative board shall ensure that the investigation meets good scientific standards and is executed at a cost that is not higher than is advocated by the circumstances' (KML I988: 950, chapter 2, sections II and I3).

Standards of good quality in scientific contexts are usually defined as the production of new or meaningful knowledge, that is, originality, potential knowledge gain, and scientific renewal. The law also emphasizes the importance of the 'costs not being higher than were advocated', which is a central concept in development-led archaeology and must be balanced against society's resources. In the relevant regulations and general recommendations for implementation of the Act (KRFS 2007:2) this is equated with cost effectiveness.

With regard to development-led archaeology, these regulations define the concept 'quality' as 'all the factors upon which the county administrative board places significance when judging a project design: an investigator's competence and organization, scientific quality, longterm dissemination of knowledge, etc. The term also concerns the level of goal attainment'. The concept 'good scientific quality' is defined as the 'use of scientific methods to acquire meaningful knowledge of relevance to authorities, research, and the general public. This requires that the result be made available and useful to the various interested parties' (KRFS 2007:2).

\section{New focus}

When the revised regulations came into force in 2008 , development-led archaeological work was set in relation to the overall goals of cultural heritage management. In the first paragraph of the revised regulations it is stated that the county administrative boards shall ensure that the goals prescribed by the Swedish parliament (Riksdagen) for the cul- 
tural environment are used as guidelines for archaeological investigative activity. The goal that is most relevant here is 'each and everyone's understanding of, participation in, and responsibility for the own cultural environment'.

This link to the overall goals of cultural heritage management has given the Heritage Board the opportunity to clarify the aim of development-led archaeology and open up a new focus. We wish to emphasize that development-led archaeology should include both scientific documentation and dissemination, along with communication, with a view to creating an understanding of its significance for archaeological knowledge and archaeological investigations. Scientific documentation is no longer the aim but the means. The aim should be to transform and present the results of the investigation for the different target groups in an interesting and relevant manner. By widening the concept of reporting beyond the mere written account, the county administrative boards are given the opportunity to initiate and commission other forms of communication and dissemination of the results.

The significance of archaeological sites for society is clarified by, for example, the increase in information which is generated by their excavation, and the experiences and reflections which the work generates among people. Today, development-led archaeology is one of the major sources of new archaeological knowledge. But the mere collection of data during an excavation, followed by interpretation and presentation in a report, does not mean that society automatically has access to the data. The generation of knowledge is an active process. Data can only become knowledge when interpreted, communicated and used. The most important duty of archaeologists must be to interpret and present their results in such a way that they are relevant, usable, and accessible to all. For this to be accomplished, it is essential that the whole development-led archaeological process is permeated with an awareness of the highest quality of standards and the way to achieve it.

\section{CRITICAL ELEMENTS IN DEVELOPMENT-LED ARCHAEOLOGY}

The concept of best practice is referred to in the guidelines for applying the statements of the Swedish National Heritage Board (KRFS 2007:2). But reality is complex and can involve conflicting interests and unprecedented difficulties. In the following section we will discuss quality in development-led archaeology on the basis of some of the most essential elements in the process. 


\section{Commissions/Tenders}

The law states that the county administrative boards are responsible for ensuring good quality in archaeological investigations. The boards are the commissioners of the investigations and construct the submission document, that is, specification, which is the basis for the investigation project design, in order to make the process legally correct and transparent for all involved, developers as well as archaeologists. Thus responsibility for both a legally correct process and the quality content of an investigation rests with the county administrative boards. The board's staff should be experts at balancing different interests in society, and in particular be able to weigh the need for the requisition of land against cultural historical values. When commissioning development-led archaeology the boards must also ensure that they have the competence to assess both the research value of the investigation proposal and the credibility of the economic calculations supplied. A further complication, built into the development-led archaeological system, involves the need for a certain amount of competitive tendering for larger investigations. The county administrative board should also, in its role as monitor, assess goal achievement and evaluate the results of the archaeological investigation with regard to scientific quality and benefit to society. In a competitive system the board's supervision and evaluation becomes especially important as a guarantee for maintaining quality. The county boards must also assess the investigator's system for knowledge generation and dissemination; in other words, the methods used by the investigator to spread knowledge of the results throughout the scientific community, for example through publications, articles, conferences and debates (KRFS 2007:2, section 7).

Reality does not always follow good intentions. Much of the administrative work at the county boards is carried out against the clock. It is also impossible for an individual administrator to be competent in all areas. This can have various consequences. The board may choose to offer only broad guidelines for the direction of the investigation and its level of ambition or thoroughness, and then leave it to the investigator to formulate the plan of action. It has sometimes happened that the board has specified the aim and direction of the investigation so narrowly as to restrict the investigator's creativity and chances for groundbreaking research. The boards' administrators must have substantial competence to be able to guide an investigator onto the right track and stimulate qualitative research questions. Establishing networks is im- 
portant in this regard, as is collaboration with county administrative boards which provide wider and more creative environments of quality.

\section{Level of ambition}

Sufficient resources are necessary to produce an adequate basis for a decision, or to conduct an investigation of high quality in terms of both fieldwork and scientific interpretation, and to communicate the results. The formulation of a level of ambition for an investigation is a critical factor. This can be very marked in the case of a field evaluation, which is the basis for a decision regarding any further excavation. The field evaluation can be said to be a key factor in the success of the process as a whole.

A well-balanced level of ambition is also vital for the cost-effectiveness of an investigation. When an investigation costs large sums of money, products and knowledge of great value for society must be produced. The county administrative boards have the difficult task of promoting archaeology before other interests in society, and in their commissions they must be forceful enough to demand archaeology of good quality.

\section{Sufficient time}

A factor that is partly connected with the above argument is scarceness of time. This does not concern development-led archaeology alone, but is characteristic of much of the planning in society today. Building projects are steered to a great extent by budgets and political decisions. Furthermore, society's primary focus is never on archaeology but on the activity which gives rise to the investigation.

For development-led archaeology the time factor is a top priority. The process in which permits are granted by the county administrative boards determines the cultural landscapes that we hand down to future generations, and is thus a process that should not be hurried. In archaeological investigations time is not only limited by the amount of resources, but also by a lack of real time, partly on the practical level in order to administrate complicated investigations, and partly so that analyses are ready before the final interpretations are formulated. Large-scale investigations contain major research factors that demand time for consideration, which cannot be forced without adversely affecting their quality.

Then there is the aspect of calendar time or the seasons. Gener- 
ally speaking the building industry has developed into a year-round enterprise. All consultants, and this includes archaeologists, are now expected to be active during the winter months. Archaeological fieldwork, however, is not a matter of digging ditches or laying down pipelines but discerning and interpreting various colour changes in the soil and collecting very small artefacts. The quality of fieldwork is greatly dependent on weather conditions, and work under poor lighting and in the cold should be totally avoided. However, this is not always possible today. Archaeologists are forced to be active during most of the year. Sometimes important investigations have to be conducted in severe winter conditions.

\section{The archaeological craft}

Much of archaeological knowledge is based on experience. Besides being able to relate to previous research and theories, an archaeologist must also recognise artefacts and sites which may be hidden, fragmentary or in poor condition. For a field archaeologist there is the additional need to be able to choose methods that are suitable for each specific type of site and situation. In other words, it is a matter of extracting information from soil of different nuances and consistencies. Archaeologists dealing with development-led archaeology must be able to formulate relevant questions in a very short time, and address material which they did not choose in the first place. The material, i.e. the archaeological site, is in addition only partly known in advance. The quality of the archaeologists' work is to a very high degree determined by the ability to be flexible and adaptable throughout the entire investigation process.

Each investigation offers new primary material which can be used for rewriting history. This is not always apparent to the uninitiated from a report. Documentation and finds may be utilised in an unimaginable amount of studies and analyses, of which only a fraction are carried out during the investigation. In other words the material from an investigation still contains a large part of its direct research potential when it is placed in libraries, archives and stores. The documentation is analysed, interpreted and packed away in reports and articles, to be of later service to research and society.

The quality of the knowledge that comes from an investigation is always dependent on the quality of the archaeological craft. It can never be said too often that archaeological excavations cannot be repeated! The documentation and finds are all that survive, and ideally it should 
be possible to use them for a host of different topics and studies. It comes down to strict scientific accuracy, sufficient time and quality assurance.

The documentation of an investigation is determined by the method of reporting and of finds management. The quality of the documentation (i.e. database) shows how well the investigator carried out the investigation; in a report it is easier to hide any shortcomings. To ensure that the investigation can lead to major opportunities for study and analysis, both within the confines of the investigation and afterwards, a carefully prepared strategy, adherence to accuracy, and sufficient time are required. In a stressful situation governed by financial resources, there is a risk that documentation will become schematised or that standards of quality assurance will be lowered.

\section{Reaching out}

In the present system of development-led archaeology an investigation should in the first hand provide a report on which to base future research. The universities today are mainly centred on teaching and can only carry out research on a small part of the contract-archaeological material. This in turn means that the potential of this material is seldom fully utilised. Application of current legislation has meant that the contextualization, communication and dissemination of the results beyond what is achieved by the written report are not considered to lie within the mandate of the contract. The county museums have been suggested as further disseminators but this seldom happens.

The concept of 'reporting' (rapportering), as defined in the revised statements (KRFS 2007:2), includes all documentation that is produced during an investigation where material is described, interpreted and presented. Reporting should be related to the target groups. This should be viewed in the context of the new focus of development-led archaeology as discussed above, where the developer's burden of cost, where relevant and suitable, not only covers basic documentation (site recording, etc.) but also a critical scientific publication and a popularized account, or some other form of reporting. We cannot measure the quality of development-led archaeology until the results are transposed into knowledge and are discussed among those in both the archaeological world and society in general.

Results are communicated to the research community in written form through reports and articles and verbally in seminars and lectures. Efforts are made to communicate with the public as long as the 
investigation is in progress. When the public visits the excavation site the archaeological investigation provides not only information about the past but also insights into the growth of the cultural landscape, and gives rise to interesting reflections about the necessities of life for countless generations, etc.

The last 30 years of development-led archaeology have produced a considerable amount of primary material, opening up new inroads into prehistory and the Middle Ages. Completely new images of many periods and places have been obtained. However, this new information is not as available to society as it should be, given the amount of work put into its retrieval. The idea behind development-led archaeology must surely be that as many people as possible are able to comprehend the knowledge attained and that they should find this knowledge relevant and interesting. The fact that development-led archaeology does not always reach its target groups has several likely causes.

The reporting that is done at present is not sufficient for reaching the great number of people in society who are interested in history and archaeology. This requires that the results be presented firstly in a way that makes them accessible to different groups, and secondly through the right channels to reach them. This often demands considerable reworking of the findings and a high degree of interpretation.

The results from a single investigation are rarely significant without first being analysed together with the results of other investigations. A further level is required if the results are to be suitable for scientific journalism. At present the large infrastructural undertakings that include archaeological investigations provide the greatest surplus value to society. From these large ventures we are often provided with concluding scientific interpretations, popularized accounts, as well as lectures and guided tours for the public. However, the budget of the present system covers only fieldwork and the investigation report. Possibilities for syntheses and larger presentations are highly limited. Such are considered to lie outside the scope of development-led archaeology, which thereby becomes synonymous with basic research and purely regional character. The project nature of development-led archaeology also means that there is a definite cut-off as soon as the budget is used up and the final report submitted. The development-led archaeologist must immediately seek out the next contract, dropping all contact with the previous investigation, physically and mentally. 


\section{Public planning}

Archaeological investigation should provide a qualitative input into public planning, with relevance to a sustainable use of the landscape and the cultural environment. Collaboration between the developer and the county administrative board is vital at an early stage. If all important matters are laid on the table success is guaranteed in the ongoing process. The outcome of development-led archaeology is to a great extent determined by the degree of cooperation between the different parties involved.

A considerable amount of public planning material is gathered when making an archaeological impact assessment and evaluation. While the primary aim is to gain information about archaeological sites within the area under development, a range of analyses and reports are drawn up with wider relevance to general public planning of the environment and landscape. This information is of interest not only to county administrative boards but also to municipal authorities. But we have already noted that the results of archaeological investigations are not readily integrated in detailed development plans in the same way as other impact assessments are. In the actual exploitation project this information has a natural and immediate role to play, but a large part of the findings have even greater value than this. For example, a major untapped potential lies in the integration of the conclusions in the municipal comprehensive plans. But there is no tradition of collaboration between municipal authorities and archaeologists on such far-reaching issues. Reviews of investigations that have been carried out would be considerably eased by an investigation register.

\section{CHALLENGES OF THE FUTURE}

The discussion above shows that there is a great need for continued efforts to increase the adequacy of the development-led archaeological system and to improve its quality. What aspects do we wish to retain and what should we develop? During a conference on quality in Swedish development-led archaeology held in 2009 this problem was brought up and many new ideas were aired (Riksantikvarieämbetet 20I0).

The county administrative boards are a key factor in the system. Many evaluations and reports have pointed out the problem of shortcomings in their resources (Riksantikvarieämbetet 2004; SOU 2005:80; Wetterberg 2008). The Heritage Board has produced guidelines and 
held seminars and conferences with the aim of supporting the county administrative boards, but this is not sufficient. The networks that have been created between the different boards aid the exchange of competence and the creation of high-quality milieu (cf. Länsstyrelsen Södermanlands län 2009). But this falls short in the case of large-scale developments, with evaluation of project designs almost on a level with applications for full research projects. Sweden has no group of expert advisors that the country administrative boards can turn to. There have been previous attempts (I995-200I) with research coordinators and so-called controllers. Perhaps it is time to take up the question of special competence once again in support of the county administrative boards, or to formalize cooperation between the different boards. This is an area of great potential for furthering cooperation between authorities and universities.

According to recent statistics, about $\mathrm{I} 200$ archaeological investigations are carried out each year in Sweden, of which approximately I 50 are excavations (Riksantikvarieämbetet 2008). The findings from development-led archaeology are very fragmented because they are often published only in reports that relate to each separate investigation. Syntheses and summaries would in our opinion make these results far more accessible to people outside the archaeological community. Development-led archaeology is in great need of summary conclusions and syntheses on a national level, which can be used as a foundation for scientific journalism and for history writing of interest to the greater public. Both geographical and thematic syntheses are needed. This, however, cannot happen within the present system where the budget is restricted to the investigation of a single site. It is also unreasonable that such a cost be placed on the developer. A formalised opportunity to write syntheses would probably produce a marked rise in quality, both scientifically and communicatively.

To further improve the flow of knowledge, the dialogue between the various actors needs to be strengthened within both development-led archaeology and society at large. Today there is no forum or formulated goals for the long-term generation of knowledge within development-led archaeology, either on a regional or national basis. One way to eliminate the current shortcomings in the dialogue would be to provide regional strategies for archaeology. With the county administrative boards in a central position, the idea would be that the different actors and interest groups together formulate what they wish to achieve with 
development-led archaeology in their county or region. It is envisaged that relevant questions would be discussed, and gaps in knowledge that became apparent would advance coordinated opinion about relevant issues. Another possibility is to have museums become more involved and to call them in at an early stage in the investigation process.

There is no national quality assurance for the outcome of development-led archaeology. Today the county administrative boards hold full responsibility for monitoring the scientific quality of an investigation. These boards, however, have a regional perspective and find it difficult to carry out quality control and assess the scientific value of the results. Some European countries, for example France and Denmark, have a multifaceted system for quality assessment as well as a stronger organization such as a national quality evaluation council. Is this something that Sweden could try?

Carolina Andersson, Riksantikvarieämbetet / The Swedish National Heritage Board, Samhällsavdelningen, Box 5405, I I 484 Stockholm, Sweden

Agneta Lagerlöf, Riksantikvarieämbetet / The Swedish National Heritage Board, Samhällsavdelningen, Box 5405, I I 484 Stockholm, Sweden

Eva Skyllberg, Riksantikvarieämbetet / The Swedish National Heritage Board, Samhällsavdelningen, Box 5405, I I 484 Stockholm, Sweden

\section{References}

APPAG 2003. The Current State of Archaeology in the United Kingdom. First Report of the All-Party Parliamentary Archaeology Group. London. (www.sal.org.uk)

Demoule, J.P. 2007. Scientific quality control and the general organization of French archaeology. In: Willems, W. \& Van den Dries, M. (Eds). Pp. I35-I 47. Quality Management in Archaeology. Oxford: Oxbow.

Doyle, I. 2008. "Archaeological Research in Ireland: Recent Developments". Conference paper in EAA session Models of Delivering Research in Developmentled Archaeology. EAA I4th Annual Meeting. Malta I6-2I September 2008. Abstracts book. Pp. I7I. Valletta: University of Malta.

EAA 2005. European Association of Archaeologists, Conference session Quality assurance in archaeology.

EAA 2008. European Association of Archaeologists, Conference session From the Cradle to the Horizon: the Valletta Convention and the Future of European Archaeology.

Expert Advisory Committee, Department of the Environment, Heritage and Local Government Dublin 2008. Review of Archaeological Policy and Practice. Dublin.

European Treaty Series No.I43. European Convention on the Protection of the Archaeological Heritage (Revised) Valletta, I6.I.I992. Council of Europe. 
Gábor, V. 2008. “Archaeology and Development: Who Will Bite the Dust? Looking for a Working Model of Archaeology in Hungary". Conference paper in EAA session Models of Delivering Research in Development-led Archaeology. EAA I4th Annual Meeting. Malta I6-2 I September 2008. Abstracts book. P. I72. Valletta: University of Malta.

Hinton, P. \& Jennings, D. 2007. Quality management of archaeology in Great Britain: present practice and future challenges. In: Willems, W. \& Van den Dries, M. (Eds). Pp. Ioo-I I 2. Quality Management in Archaeology. Oxford: Oxbow.

KML. Lag (I988:950) om kulturminnen m.m. (SFS I988:950). The Heritage Conservation Act (1988:950).

KRFS 2007:2. Riksantikvarieämbetets föreskrifter och allmänna råd avseende verkställigheten av 2 kap. IO-I3 SS lagen (I988:950) om kulturminnen m.m. (www. raa.se)

Lüth, F. 2008. Discussion report. Council of Europe, Committee on Culture, Science and Education, Conference on Rescue Archaeology. Paris.

Länsstyrelsen Södermanlands län 2009. Samverkan ger styrka! Redovisning av uppdrag 39 i 2009 àrs regleringsbrev I juni 2009. Rapport nr 2009: I. Stockholm: Länsstyrelsen Södermanlands län.

Nationalencyklopedin n.d. (www.ne.se).

Oliver, A. 2009. International evaluation of knowledge development in connection with archaeological investigation activities under the new Danish Museum Act 2002. Unpublished Report.

Pearce, M. 2008. “Grey Literature: The Philosopher's Stone?”. Conference paper in EAA session Models of Delivering Research in Development-led Archaeology. EAA I 4th Annual Meeting. Malta I6-2 I September 2008. Abstracts book. Pp. I70-I7I. Valletta: University of Malta.

Riksantikvarieämbetet 2004. Uppdragsarkeologi 2003 och 2004. Uppgifter om den uppdragsarkeologiska verksambeten och länsstyrelsens handläggning av ärenden enligt 2 kap. I I-I 4 SS KML under åren 2003 och 2004. Stockholm: Riksantikvarieämbetet.

Riksantikvarieämbetet 2008. Tillämpning av 2-4 kap. Lagen (I988:950) om kulturminnen m.m. Statistik gällande 2007. Rapport från Riksantikvarieämbetet 2008:6. Stockholm: Riksantikvarieämbetet.

Riksantikvarieämbetet 20I0. Dokumentation frän Riksantikvarieämbetets konferens om kvalitet i uppdragsarkeologin 23-24 november 2009. Stockholm: Riksantikvarieämbetet.

SOU 2005:80. Uppdragsarkeologi itiden. Betänkande av Uppdragsarkeologiutredningen.

University College Dublin and Heritage Council 2006. Archaeology 2020. Repositioning Irish Archaeology in the Knowledge Society. A realistic achievable perspective. Dublin.

Van den Dries, M \& Willems, W. 2007. Quality Assurance in Archaeology, the Dutch Perspective. In: Willems, W. \& Van den Dries, M. (Eds). Quality Management in Archaeology. Pp. 50-65. Oxford: Oxbow.

Wetterberg, O. 2008. Utredning angående uppdragsarkeologin. Unpublished Report. Göteborg.

Willems, W.J.H. \& Brandt, R.W. 2004. Dutch Archaeology Quality Standard. Haag: Rijksinspectie voor de Archeologie.

Willems, W. \& van den Dries, M. 2007. The origins and development of quality assurance in archaeology. In: Willems, W. \& Van den Dries, M. (Eds). Quality Management in Archaeology. Pp. I-I 2. Oxford: Oxbow. 


\title{
COMMENTS ON QUALITY FROM THE IVORY TOWER
}

\author{
Håkon Glørstad
}

Andersson, Lagerlöf and Skyllberg raise several important questions concerning the issue of quality in development-led archaeology. Their analysis of the system is precise and thought provoking. From a Norwegian point of view, however, one has to notice a blind spot in their argumentation. This area of debate was originally of great importance to Swedish archaeology and is still in prime focus in the Norwegian management of cultural heritage. The authors point out that in Scandinavia there now exist two different systems of doing developmentled archaeology, that is, inside a state monopoly and as part of a competitive system. The main trend in public life in Scandinavia has been to break down the state monopolies and replace them by different systems of private or semi-private competition. One might ask why development-led archaeology in countries such as Norway has not been reorganised in a similar manner, as the idea of such a reform has regularly been suggested by several politicians and bureaucrats. I think the main reason for the Norwegian hesitance has been a continuous regeneration of the intellectual fundament of development-led archaeology. Development-led archaeology is primarily done in order to secure source material and documentation of past societies for research, when development plans are threatening the heritage. The importance of $u s$ ing this knowledge in public life is still sub-ordered such an ambition. There are two interrelated consequences of this stand. Firstly, in this system the developer is not expected or obliged to pay for any research or public appropriation of the past. The developer only pays for securing the source material for storage and future research. Secondly, this 
research as well as almost all archaeological rescue excavations in Norway is done by the universities, or to be more precise, by five university museums. ${ }^{\mathrm{I}}$ Here we reach, I think, the aforementioned blind spot. This system namely, just as the Swedish, divides the world between an effectuated and a critical domain (Kant I992). The difference is, however, that the demarcation lines in Norway cut right through the field of cultural heritage management, while in Sweden, as far as I can tell, this activity generally belongs to the effectuated part of society. In Norway, development-led archaeology is integrated into the universities because the primary function of this kind of archaeology is not to please society or consumers, but to secure valuable source material for critical and free research and knowledge production. Parts of Norwegian cultural heritage management represent effectuated social functions. That is, they manage the public goods according to the state's legislation. These institutions are the county administrations' archaeological offices, the Directorate of Cultural Heritage Management and the Ministry of Environment. They do not, however, perform research as part of their portfolio. Thus the system of cultural heritage management is constructed as two different interacting domains in order to secure quality and criticism. ${ }^{2}$

This sheds some light on the question of securing quality in Swedish archaeology. In modern society, the universities are supposed to create knowledge of high quality, through large research environments, processes of critical peer evaluation, and with close connections between research and education/reproduction. This knowledge should be produced for its own sake - not as a response to any needs of consumers or users. This is the ideal of the ivory tower. According to the authors, in Swedish development-led archaeology this kind of knowledge is no longer the end product of research; it is only a means for creating a product for consumption: "Scientific documentation is no longer the aim but the means. The aim should be to transform and present the results of the investigation for the different target groups in an interesting

1 The Norwegian system has undergone several healthy reforms in order to trim and improve the logic of its structure. Management according to the legislation and research/ knowledge production has thus been better divided. A few deviations from a clear-cut division between these functions still exist, but the main trend is clear (Glørstad \& Kallhovd, in press).

2 Needless to say, there is a constant temptation for the universities taking part in development-led archaeology to redefine their role similar to the rest of the field of cultural heritage management. 
and relevant manner." This is the magical formulation of the market and the turn towards the logic of a market. It is of great importance for the question of quality. Today the logic of the market is not about selling a reasonable product at the best price. This was perhaps the ideology of the production societies in the twentieth century, but in the twenty-first century we are part of consuming societies where there is little interest in production. Instead what is at stake is consumption, or to be more precise, maximising consumption in order to create and recreate identities as social life. This logic of our contemporary world is very precisely defined by Zygmunt Baumann (2008), leaving little optimism for any hope of securing traditional concepts of quality inside such a system. The effects of the new consuming ideology are displayed in various aspects of present-day human life. Most obvious is perhaps the transfer of large-scale production from the industrialised countries in the West to the remote East, enabling very low prices for the products. The low prices measured against Western ability for buying enable high consumption rates - and few products are actually made to last. Durability is not in the interest of a consuming society - thus the question of traditional quality boils down to the minimum standards of consumer organisation or governments. A noticeable consequence is the breakdown of the traditional Western concepts of humans and individuality, enabling the consumers to be recreated through a process of total commodification.

The authors rightly identify this process, not only in developmentled archaeology but also in the educational system. Today university education is transformed into creating a market for consumption of points and courses, hence fragmenting the traditional disciplines and making education a question of creating your own individualised competence - becoming unique and attractive on the work market by consuming standardised products. Most fields of social research and humanities have even developed ideologies suitable for this new situation. We also have some remarkable examples in archaeology (first and most clear-cut: Miller 1987). Two consequences can be drawn from this. First, the universities are no longer a guarantor for quality in archaeology. Second, the concept of quality will be equated with the concept of consumption - who will need or appreciate the products offered? In my opinion it is utopian to think that the market system in archaeology itself would secure quality - if so, that would have been a clear and rare exception in history. The market first and foremost secures 
high activity, and consumption rates and products should thus be adjusted to an average audience.

As initially remarked, the choice of financing research is crucial. The Swedish system allows for financing research through the money the developer is obliged to pay. This creates a great potential for increased employment and activities. In general, the market system is a much better creator of jobs and positions in archaeology than state monopolies. (This is, of course, paradoxical for those who believe that a market would reduce prices.) Embracing the market, the fundamental challenge is to recreate the critical functions the way Immanuel Kant defined them (Kant I992; see also Bourdieu I996, and Glørstad 2008 for archaeological discussion on the subject) in such a system. How can we create critical functions that are not part of the effectuated system that funds excavations and research? In Norway this is done by dividing strictly between securing sources and doing research. However, in the Swedish system this would likely be too large a sacrifice; it would probably mean giving up funding and reducing the level of archaeological activity. This touches upon a delicate aspect of the question of quality - it is intimately connected to the question of social dignity. The Norwegian system has created a large stock of archaeologists who do not have permanent positions or full-time jobs. Their choice of making a living out of short-term contracts in development-led archaeology actually disqualifies them from permanent positions because they are spending their time getting competence that is not highly rated in management and research. Thus, the outcome of their career runs the risk of turning into a social tragedy - they will not be able to have a normal family life, and as soon as they age or become injured in such a way that fieldwork no longer is possible they will not be considered a resource of interest for the archaeological employers. A regulated market would to a larger degree offer them social security and more stable jobs. Making quality a question of interest and consumption also creates a diverse work market. Such an asset is hard to resist.

Now, these comments might seem critical and a bit depressing, and certainly they must be balanced by a less principled and more pragmatic evaluation of the quality of Swedish development-led archaeology. In my opinion there is a lot of solid, high-quality archaeology done in Sweden today. The reasons for this good performance also deserve some comments. Most Swedish archaeologists are still primarily writ- 
ing for an audience that consists of other researchers - thus the rather general standards of writing scientific texts are still prevalent. Closely related to this practice is also a definition of the function of the text not to write for different target groups in an interesting manner, but to present scientific documentation of high quality and thus of relevance for the work of one's peers. As long as the system of education is still granting such virtues, the standards will likely be kept. Unfortunately, as the authors say, this can no longer be taken for granted. Despite this regrettable development, the connections to education and university research should in any case be strengthened in development-led archaeology. Many historical examples point out such organisations and activities as the most stable element for securing high quality in research and knowledge production, and not least some critical evaluation of the work done. Securing quality in Swedish cultural heritage management can probably not be solved in a long-term perspective inside this framework exclusively. High quality implies solid reproduction and a certain amount of institutionalised disinterest. The way I see it, such assets can not be offered inside the present system of Swedish cultural heritage management alone. By this I do not mean that such qualities are absent from development-led archaeology, but they are not functions of the system - thus there exist no mechanisms for their reproduction.

\section{References}

Bauman, Z. 2008. Konsumtionsliv. Gothenburg: Daidalos.

Bourdieu, P. I996. Homo academicus. Stockholm: Brutus Östlings Bokförlag Symposion.

Glørstad, H. 2008. En nisses tale for akademiet. Primitive tider I0. p. 95-I07.

Glørstad, H. \& Kallhovd, K. in press. Rescue archaeology initiated by research a contradiction in terms? - The role of the universities in Norwegian Cultural Heritage Management. In: G. Blancquaert, F. Malrain, H. Stäuble and J. Vanmoerkerke (eds.): Understanding the past: a matter of surface-area. Acts of the XIIIth session of the EAA Congress, Zadar 2007. BAR International Series, Oxford: Archaeopress.

Kant, I. I992. The conflict of the faculties. (Original: Der Streit der Fakultäten, I798) Lincoln: University of Nebraska Press.

Miller, D. I987. Material culture and mass consumption. Oxford: Basil Blackwell. 



\section{THE KEY CHAIN OF ARCHAE- OLOGY IS NOT STRONGER THAN ITS WEAKEST LINK}

Joakim Goldhahn

We live in a changing world in which terms such as "cost efficiency" and "quality assurance" have become doxa. This is apparent to the archaeological field in general and to development-led archaeology (DA) in particular. Since the new regulations for the DA in Sweden were announced, I have noticed a rising discontent among my archaeological colleagues. This goes for researchers at the academic strongholds as well as those who work on a daily basis with DA at the National Heritage Board, museums, foundations and firms, but also those situated at the county administrations in different parts of Sweden. All seem to agree that the current system is not functioning and that something must be done.

To begin with, I find Swedish DA among the most progressive in the world. Many of the archaeological accomplishments of the last decades are not only fascinating but mind-blowing, and all in all the results of DA have significantly broadened our archaeological knowledge. This is not least manifested in the long list of academic theses that are based on the results of DA, a fact that has few parallels in the rest of the world. Simply by looking at the bookshelves in front of me, I can spot 3 I theses from the past 20 years based on DA, and the list could easily be made longer. More theses are also underway. The impact of DA is also manifested at international conferences, where archaeologists and others who work with Swedish DA are often well represented and appreciated. DA from Sweden holds a high international standard 
and status, a fact that we all should be proud of. Now, however, it appears that this good reputation is about to change, to the worse, and it seems to be happening faster than we can grasp.

Colleagues who have been harvesting in the DA field longer than I have worked as an archaeologist are now thinking of resigning, though not because of age or worn-out bodies - no, "It's just not fun anymore". The reason for their discontent is that the present practice of DA has slimmed down the framework of doing "proper archaeology" to the bare bones, and sometimes not even that. The time for preparation, fieldwork, reporting, scientific evaluation and writing is constantly decreasing. Not to mention the decreasing time for public archaeology. Meanwhile, an increasing amount of time and energy is being spent on writing well founded, scientific based applications, most of them of no use. The cheapest bid wins. The exceptions are few and must be considered to be just that: exceptions. Appeals against the decisions of the county administrations have been an unspoken rule, leading to unwanted delays and, even worse, mistrust among colleagues. This has not only affected the already hard-pressed economies of the parties concerned, but also created an unwanted burden on the already understaffed county administrative boards. Still worse, the developers who pay the bill have been suffering through these delays, with overpriced construction projects as a result. The goodwill and good name of archaeology cracks. All lose.

In a time like this, when a united archaeological corps is required, fragmentation has been the result. I have recently experienced veritable shafts between the various archaeological fields and contractors, and from what I can tell, these shafts seems to increase. I have experienced how former friends and colleagues from the past start to give each other bad names, now in the form of disguised competitors. Recently, I heard a colleague curse the fact that she could not visit a particularly interesting DA excavation simply because it was a competitive firm that performed the dig. Again: All lose.

The dissatisfaction with the new DA rules is documented and widespread. Frustration increases. It was therefore only a matter of time before the current, most relevant article from Andersson, Lagerlöf and Skyllberg would see the light.

Andersson et al. initially wonder what "good quality" stands for within DA. It's a good question. While "cost efficiency" is easy to demonstrate, since most of the time it spells less ambition and costs, "qual- 
ity assurance" is much harder to grasp. If I should speak from my own heart, and now and again that might be good, one can really wonder if the county administrations have considered this notion at all, and if so what this consideration ended in. And to be fair - and one should always be fair - one can also wonder what kind of means the county administrations have, in terms of increasing funds, when it comes to living up to the new regulations. It is not easy to make something out of nothing.

According to the new regulations, "quality" within DA is related to scientific progress. This stands in sharp contrast to the increasing lack of archaeological knowledge among the county administrations, as the authors imply. It is easy to see how this came about, not least since the archaeological knowledge is changing shape at a pace that is hard to handle. This is also evident among academics. Now and then I am asked to act as an expert on the behalf of international peer review journals, scientific assessments of manuscripts and theses, and project applications related to my own research fields. More than once I have found myself saying "no", simply because of the fact that I do not possess the specific knowledge required. Nowadays, all archaeologists do not know everything. In contrast, the more often than not understaffed county administrations are not in any position to say "no". They have to handle every issue, from the early Stone Age to the early modern period. On top of that they are expected to have an overview of the scientific progress in each and every field of archaeology. As administrators at the county administration they are expected to be omniscient. Moreover, often the project they empower has a budget that is five to ten times higher than the scientific applications submitted by distinguished researchers to the Swedish Research Council and the Bank of Sweden Tercentenary Foundation, different EU foundations, etc. The county boards' decision-making and power over the archaeological knowledge production is thus ten times larger and more comprehensive than that of representatives of the academic fields of archaeology. The only difference is that the academic evaluators have to be able to document some kind of formal academic or scientific expertise, a demand that is not required for the staff at a county administration. Is this wise, logical, reasonable?

To assess the quality of an offer is one thing, but to assess how an archaeological investigation is carried out and implemented is another matter. To be able to perform quality assurance like this requires that the 
person actively follow the steps and decisions made in the field. Today there are, to my knowledge, few or very weak routines for this. Without a doubt, the largest projects get the most attention. As for those who are supposed to perform this quality assessment in the field, often they have no time to visit the digs they should assess, no matter how much they might like to or even try. All too often the digs come to an end without any visits made at all.

In this context it is also worth noting that more and more excavations are performed during the winter months. And as anyone who has tried to excavate a grave at five degrees below zero and in 25 centimetres of snow knows, it is anything but good. Yet it happens, and nowadays all too often. What steps have been taken by the county administrative boards to ensure and assess the quality of the investigations carried out under these circumstances? Considering the new guidelines for DA, which enhance the goal of scientific progress, we might wonder why these digs are allowed at all?

Another problem with the current situation, as I see it, is that the quality assessment that is performed never seems to end in any consequences or complaints about how the hands-on archaeology was carried out. Despite numerous hair-raising examples, I can not recall any archaeological excavations or firms that received any reprimands from the county administrations. A case that I found especially upsetting was a trial excavation in the close vicinity of one of Sweden's most famous and venerable monuments. Several previous and contemporary colleagues had noted stray finds of artefacts and settlement-indicative features in the I 5,000 square meter field that was affected by plans to build residences. Within this field the DA firm that performed the trial excavation opened up two separate trial trenches, which had a combined length of 2 I meters. Not very surprisingly, they did "not find anything" and the whole area was allowed to be built on - no further antiquarian investigation was deemed necessary. This judgment was reached after opening $2 \mathrm{I}$ out of $\mathrm{I} 5,000$ square meters. The cost of this trial excavation stopped at I6,7 I 5 Swedish crowns. One third of the money at disposal was returned to the grateful developer. The whole performance took four hours. Not even one per cent of the total area was investigated. Today the same area is for sale for around I 2 million Swedish crowns. What is telling with this story is that the people in charge at the county administration did not have any objections to this ridiculous routine. The only ones who have complained are the 
people living in the vicinity who feel they have been robbed of a vital part of their history. Surely we can do better.

In line with Andersson et al., I believe that the spread of scientific results is something that ought to be discussed further. As a frequent visitor to conferences and a reader of scientific publications, I find it very easy to note that only certain parties involved in DA are conveying the scientific achievements in this way. Some of the firms seem to have made an explicit decision to skip this dialogue and use the funds to create a satisfactory surplus for their foundations or shareholders. Without naming any parties, most of them never seem to visit scientific conferences, which must be considered odd especially since they are all expected to contribute to the scientific progress through their involvement in DA. Having said this, those who are supposed to assess this scientific progress are also missing.

In the contact I have had with county administrative boards in different parts of Sweden, I have often been amazed by the embarrassing level of archaeological knowledge communicated. Of course there are exceptions to every rule, but if we consider this matter a bit further, it is a fact that the sector that has the most power over the archaeological mission has also the least knowledge of current archaeological standards, methods, theories, and, in short, the archaeological knowledge production. A fact that ought to be reflected upon.

Andersson et al. suggest several related ways to improve the outlined situation concerning DA. One way is to demand that those who mandate DA should meet the same requirements for scientific standards as those who perform the development-led archaeology. I think that all archaeologists would find this reasonable. The authors also suggest a more extended cooperation between the county administrative boards in Sweden in order to enhance their skills and broaden their all too often - regional archaeological horizon. Another way would be to introduce a "multifaceted system for quality assessment as well as a stronger organization such as a national quality evaluation council".

The last suggestion might be worth considering, but whatever path we choose to follow in the near future, I agree with the authors that something has to be done. For things to change to the better, I also think it is necessary that specific financial resources be provided for this task. To be fair: that ought to have been a requirement from the beginning when the new regulations were handed over to the county administrative boards. As things developed, they did not have a reasonable chance 
to respond to the higher standard and demands on their work that followed. If the specific financial support is not provided, I can not really see how the county administrative boards can live up to and protect the good intentions of the Heritage Conservation Act.

With this being said, I feel it is essential that all archaeologists realize that this is not just an issue for our colleagues at the county administrative boards to resolve; on the contrary, it concerns us all. If we want to see positive changes in the prevailing conditions, this is not the time to involve ourselves in any unproductive disputes on behalf of the form and content of assessed DA and whether this can be measured or not. In my opinion, this concerns all of us; we stand and fall together. The key chain of archaeology is not stronger than its weakest link. It is high time to act. 


\section{'QUALITY' ADVICE FROM FRENCH PREVENTIVE ARCHAEOLOGY}

Nathan Schlanger \& Kai Salas Rossenbach

In their lucid and thought-provoking paper, Carolina Andersson, Agneta Lagerlöf and Eva Skyllberg clearly identify the looming quandary of contemporary archaeology: how can we promote our professional concerns with scientific and patrimonial 'quality' in a context increasingly dominated by (often short-term) economic and political considerations? Almost twenty years have passed since the Valletta Convention called for the reconciliation of archaeology and spatial planning $\left(\mathrm{CoE}\right.$ treaty $\mathrm{n}^{\circ} \mathrm{I} 43$, I992), but some European countries still remain ambivalent or uncertain regarding the systems they have chosen to implement. In terms of their overall policies on archaeological heritage management, Sweden and France are both clearly on the 'public service' end of the spectrum, where the state is expected to take responsibility over threatened archaeological remains and then control the quality of their protection and study (cf. Demoule 2002; Demoule 2010; Willems \& Van den Dries 2007:I0; Kristiansen 2009:643 ff). Given these affinities, some recent experiences in French archaeology can well serve as examples - or indeed as cautionary tales - for the unfolding situation in Sweden.

A brief terminological excursus will clear the way, insofar as both Swedish and French can offer some linguistic depths vis-à-vis the lingua franca. In the critical spirit of this paper, the casual expression 'development-led archaeology' appears difficult to uphold. It builds on an ambiguity in the English language between a wide-ranging and noble notion of development ('sustainable', 'social', 'cultural') and the more 
down-to-earth realities of infrastructure and building works (bulldozers, surveyors, gravels and tarmacs). Clearly, the archaeology called for by the Valletta Convention can hardly be said to be 'led' by some positive developments, as much as funded, following the polluter pays principle, by the building contractors, i.e. developers, concerned. Our respective mother tongues prove here more subtle: the Swedish $u p p$ drag (as in uppdragsarkeologi) translates as 'commission' or 'assignment', while the French archéologie préventive can well be rendered as preventive archaeology, in the mode of preventive medicine or preventive detention (to prevent archaeological remains from being destroyed without study). In this sense, the archaeology that is 'commissioned' or 'preventive' can have as its counterpart the archaeology that is 'programmed' or 'initiated' on unthreatened sites (rather than the expression 'research-led', which implies that the 'developer-led' is bereft of research considerations). Overall, these notions can serve us to place the 'lead' on quality where it squarely belongs: not with the building contractors, but rather with the archaeological operators, prescribers and regulators.

As we know, measures to ensure that 'commissioned' archaeological work remains of high quality in scientific and patrimonial terms vary considerably from country to country, in the light of different traditions of governance, spatial planning, legislation, academic norms, professional standards, and so on (see recent overviews in D'Andrea \& Guermandi 2008; Bozoki-Ernyey 2007; Demoule 2007; World Archaeology 4I/4, 2009; Schlanger \& Aitchison 2010). So far as France is concerned, the long awaited heritage law of $200 \mathrm{I}$ emphasizes that (in paraphrase) preventive archaeology is a mission of public service governed by the principles of scientific research, which seeks to identify, safeguard, study, interpret and widely disseminate results pertaining to threatened archaeological remains (for recent developments in French archaeology see Demoule \& Landes 2009; Giraud 20 I0; Schlanger \& Salas Rossenbach 20I0) This 200 I law also brought about the creation of INRAP, transforming and expanding a pre-existing association into a national research institute, with now over I 800 archaeologists. In operational and administrative terms, a clear distinction was formalised between an evaluation or diagnostic phase, where previously unrecorded archaeological remains are identified on land slated for development (mainly through systematic trial trenching), and an excavation phase, which focuses on the remains deemed worthy of scientific 
recording and study. Both phases are undertaken upon prescription by the Ministry of Culture (SRA) and with the control of research designs, results and publications through regional and national archaeological bodies (CIRA, CNRA), composed of experts from universities, CNRS, INRAP, local authorities and the Ministry of Culture.

Then came 2003 and the law changed again, following a certain ideological reorientation exacerbated by pressures from developers and local representatives, frustrated by barriers to archaeological recruitments and other delays. The ensuing modifications have their direct impact on questions of quality:

- First, while the diagnostic phase is still considered a public service to be undertaken by INRAP and other authorised public bodies (with funding through a dedicated tax per square meter), the excavation phase has been formally opened to commercial tendering.

- Next, responsibility for commissioning archaeological excavations (as prescribed by the Ministry) now rests completely with the developers. Public developers can themselves set the relative weight they accord in their calls-for-tender to such factors as cost, time, or scientific quality, while private developers have no obligation at all to tender and can choose any operator at will. While a series of scientific requirements are laid out by the prescriber, it is only as a fait accompli, once the contract between developer and operator has been signed, that the state can gain a modicum of vision into the pertinence and the feasibility of the proposed research design.

- Last but not least, a licensing system for operators of preventive archaeology has been introduced. The procedure for its granting includes information on the functional offer of the candidate unit, the quantity and quality of their human resources, their budgets, infrastructures, equipment and so forth. As awarded by the Ministry of Culture, the licence can include territorial and chronological restrictions, and activities of diagnostics remain limited to public bodies. By mid 20I0, there were in France 80 licensed operators: 60 local authorities and public bodies, and 20 private companies.

Altogether, these licensed operators now undertake something like $40 \%$ of the preventive excavations in France, and this 'market' appears set to grow. On the one hand, there is increasing pressure from developers to hasten procedures and clear the grounds, including a call 
to change the rules and grant licences (including for diagnostics) to private operators specifically created by quarrying and building companies. On the other hand, some state administrations seem to exhibit a belated excess of neoliberal zeal, enticing prescribers and controllers to relax standards and unduly encourage competition. Whether this competition is really time- and cost-reducing remains to be seen, but there is no doubt that its effects on quality are detrimental. When the current tendency - exacerbated by the global economic crisis - is for archaeological operations to become predominantly commercial transactions, rendered to the satisfaction of the developer-customer with minimal analyses or publications, there is a real risk that also scientific information or research methodologies will become commercial assets or 'patents' in their own right, to be withheld from erstwhile colleagues and now rival archaeologists for the sake of some lucrative contracts, rather than shared and developed together towards an increased understanding of the past. The situation in France is not irreversible, far from it, but if there is one piece of 'quality' advice we may offer here it is to ensure that the state, its prescribers, experts and regulators are enabled and encouraged - and goaded if need be - to fulfil their roles as guardians of a quality-led archaeology, in the spirit and the letter of the Valletta Convention. 


\section{References}

Bozoki-Ernyey K. (Ed.) 2007. European preventive archaeology: papers of the EPAC Meeting, Vilnius 2004. Budapest: National Office of Cultural Heritage, Hungary - Council of Europe.

D'Andrea A. \& Guermandi M.P.(Eds) 2008. Strumentiper l'archeologie preventiva, Esperienze, Normative, Tecnologie. Budapest: $\mathrm{EPOCH} /$ Archaeolingua.

Demoule J.-P. 2002. Rescue archaeology: the French way. Public Archaeology, vol 2, pp $170-7$.

Demoule J-P. (Ed.) 2007. L'archéologie préventive dans le monde, Apports de l'archéologie préventive à la connaissance du passé. Paris: La Découverte.

Demoule J-P. 20IO. The crisis - economic, ideological and archaeological. In Schlanger N. \& Aitchison K. (Eds). Archaeology and the global economic crisis. Multiple impacts, possible solutions. Brussels: ACE/CultureLab.

Demoule J-P. \& Landes C. (Eds) 2009. La fabrique de l'archéologie en France. Paris: La Découverte.

Giraud J-P. 20IO. Organisation et structure de l'archéologie française. Archäologisches Nachrichtenblatt, vol I 5/2, pp I 50-I6I.

Kristiansen, K. 2009. Contract archaeology in Europe: an experiment in diversity. World Archaeology, vol 4I/4, pp 64I-648.

Schlanger N. \& Salas Rossenbach K. 20I0. One crisis too many? French archaeology between reforms and re-launch. In Schlanger N. \& Aitchison K. (Eds). Archaeology and the global economic crisis. Multiple impacts, possible solutions. Brussels: ACE/CultureLab.

Schlanger N. \& Aitchison K. (Eds) 2010. Archaeology and the global economic crisis. Multiple impacts, possible solutions. Brussels: ACE/CultureLab.

Willems W. \& Van den Dries M. 2007. The origins and development of quality control in archaeology. In: Willems W. \& Van den Dries (Eds), Quality Management in Archaeology. Pp. I-I 2. Oxford: Oxbow Books.

World Archaeology, vol 4I, issue 4, 2009. London: Routledge. 


\section{COMMENTS ON 'ASSESSING AND MEASURING: ON QUALITY IN DEVELOPMENT- LED ARCHAEOLOGY'}

\section{Fredrik Stjernberg}

As the authors rightly say, "It can never be said too often that archaeological excavations cannot be repeated" (Andersson et al. this volume, $\mathrm{p}$ 22). Each archaeological excavation is unique. This is one of the few things the archaeologist knows beforehand. Over the years, many sites have been irreparably destroyed by clumsy or careless excavation. The possibilities of revisiting such sites in order to gather new information about the various strata are slim. If further information cannot be obtained, each excavation becomes a study of a unique occurrence. This puts archaeology on a par with many of the humanistic disciplines, where the events to be dealt with also present themselves as unique occurrences. So maintaining quality in archaeology cannot be done in the same way as maintaining quality in the natural sciences. In the natural sciences, quality is to a great extent about guaranteeing reproducibility of results and methods. Another researcher should be able to do exactly what I did, and (at least ideally) get the same result. This is not the case in archaeology. But archaeology is also different from much of what is being done in the humanities, for two reasons. The first is that many of the methods used are taken from the natural sciences, and the second is that this kind of changing of the object of study, often to the point of destroying it, is not often found in the humanities or social sciences. But it can happen there as well at times, as 
when researchers question eyewitnesses about an event. Once the eyewitnesses have testified, their statements will have a tendency to reduce the value of further attempts to question them - there is a strong tendency for eyewitnesses to stick with their original statements. Therefore archaeology faces special problems. These problems may well turn out to be even more pressing for development-led archaeology, due to the special constraints presented by tight schedules and budgets.

So what should be done? These special circumstances make archaeology a special kind of scientific activity, but they do not mean that we have to say that attempts to make archaeology a scientific endeavour are doomed. There is still room for a fertile discussion of ways in which archaeology can be done in a better or a worse manner. But some of the answers available in other disciplines will not be very helpful in archaeology - appeals to repeatability and reproducibility will not be of much help. The usual recommendations in the humanities will also be of little help. In comparative literature, a scholar's interpretation of a poem may not be possible to reproduce - that scholar's starting point is probably not shared by many other scholars, so there will be disagreement from the very beginning. But in this case the scholar's interpretation can at least still aspire to be a contribution of good scientific quality, as long as the steps taken in arriving at the interpretation are accounted for in a systematic and clear fashion so that other scholars can assess them. This is what distinguishes a qualitatively good interpretation from mere subjective venting.

Something like this can be applied to the archaeologist's craft, but the difference lies in the kinds of steps the archaeologist takes as compared with those taken by the comparative literature scholar. The archaeologist makes use of more varied cues; evidence ranges from texts to specific aspects of those very surroundings. Artefacts, results from metallurgy and agriculture are just a few examples of things that can come in handy for the archaeologist who is trying to make sense of an excavation site. This can be done in various ways, and more to the point, it can be done in better or worse ways. A general appeal to the quality of the archaeologist's work is tempting, and perhaps necessary, here, but what does it mean more precisely?

The authors write that the regulations concerning development-led archaeology provide a two-step definition of "quality". First, there is a more general definition of what quality is supposed to mean: 
[A]ll the factors upon which the county administrative board places significance when judging a project design: an investigator's competence and organisation, scientific quality, long-term dissemination of knowledge, etc.

Second, the narrower concept of "good scientific quality" is characterized as

the use of scientific methods to acquire meaningful knowledge of relevance to authorities, research, and the general public. This requires that the result be made available and useful to the various interested parties. (KRFS 2007:2)

The first, general definition of quality leaves a somewhat unfortunate gap: quality is judged by what the county administrative boards find significant, whereas there is no guarantee that the county administration will have the interest or the competence to fully judge quality. Thus, by making the characterization of quality depend on what the administrative authorities judge to be quality, the authorities cannot (by definition) be wrong about quality - quality just is what they deem to be of significance when judging project design. So, incompetent authorities could contribute to damaging a site simply by not having understood "quality" in a useful way. But it would seem that this possibility is avoided by the next quotation, where good scientific quality is understood to include the use of scientific methods. This may well be a very small difference, but it at least indicates that the authorities should be prepared to let the assessment of whether something is of good scientific standing be a matter for scientists, not county administrators.

But what does "scientific methods" mean here? This has of course been hotly debated in the philosophy of science for many years, with a bewildering variety of suggestions as a result. Among the answers, we find Popperian falsifiability - scientific claims are falsifiable, at least in principle (Popper 1959). But it has been known for a long time that falsifiability, while perhaps good general advice for a practising scientist, cannot exhaust the nature of scientific method; there are too many examples of scientific disciplines in good standing that are not falsifiable. Other theorists have gone to extremes: Feyerabend famously held that there is no such thing as the scientific method, and hence that there is nothing external we can appeal to when trying to assess whether 
something is science, let alone whether something is of good scientific quality (Feyerabend 1975). But surely these are not the only options. An activity can be carried out in better or worse ways, even if there is no absolute demarcation between that activity and something else.

One writer who has attempted to give an account of what objectivity in science amounts to is Helen Longino. In an article (Longino I998) she sets out some requirements for attaining objectivity in scientific work. Objectivity would be important, because it stands as a necessary requirement for communication between people engaged in the discipline. Without it, we would be back to the subjective venting I spoke of above. The guidelines she provides could work as a starting point for discussion among archaeologists, setting out a kind of disciplinespecific canon, as it were, for what "good scientific quality" amounts to in archaeology. Longino claims that the following things must hold:

First, there must be accepted ways to criticize evidence, methods, assumptions and arguments. Second, there should be shared standards to which the people raising the objections can appeal. Third, the scientific community must be receptive to such criticism. And fourth, qualified practitioners in the discipline must share intellectual authority among themselves (Longino I998:I8I).

All these points merit further discussion in some other setting, but let me finish by at least sketching why these points can be of central importance to good scientific quality. The first claim, about accepted ways to criticize others, is not just a matter of etiquette. You don't have to be particularly nice. The point is rather that, when objecting, there should be some common ground between the parties in the discussion. Without that, we don't even have a subject. This is the rationale for the second point as well. As to the third point, if the scientific community is not receptive to criticism, it has left the scientific endeavour and hardened into a dogmatic sect. The final point is intended to guarantee that there will be no gurus or dictators who set out what everyone is to think.

No doubt there are many examples of scientific activities where these points are not followed. The points spell out an ideal, but the ideal is not impossible to achieve, and it should permeate the scientist's work at all times. Quality in science is to a large extent a question of doing things in the right way. 


\section{References}

Curd, M. \& J. A. Cover (Eds) I998. Philosophy of Science: The Central Issues. New York: W.W. Norton.

Feyerabend, P. I975. Against Method. Outline of an anarchistic theory of knowledge. London: NLB.

KRFS 2007:2. Riksantikvarieämbetets föreskrifter och allmänna råd avseende verkställigheten av 2 kap. I0-I3 $\mathbb{S S}$ (1988:950) lagen om kulturminnen m.m. Stockholm.

Longino, H. I998. "Values and Objectivity". In: Curd, M. \& Cover, J. A. (Eds). Philosophy of Science: The Central Issues. New York: W.W. Norton.

Popper, K. 1959. The Logic of Scientific Discovery. London: Hutchinson. 



\section{REPLY TO COMMENTS ON}

THE ARTICLE 'ASSESSING

AND MEASURING: ON

QUALITY IN DEVELOPMENT-

LED ARCHAEOLOGY'

Carolina Andersson, Agneta Lagerlöf \& Eva Skyllberg

It has been very rewarding to read the four comments on our article. The editors of CSA are to be applauded for engaging persons who, from both a Swedish and an international perspective, discussed so interestingly not only the concept 'quality' but also the specific concept 'scientific quality', as well as the particular characteristics of 'quality within development-led archaeology'. Many interesting views and angles have been presented, and though it would be very instructive to comment on all, for reasons of space we must confine ourselves to a few.

As we emphasised in our article, the revised regulations for the Swedish Heritage Conservation Act (KML) have broadened the aim of development-led archaeology to include scientific documentation and dissemination of the results; and the overall goal is to interpret and present the investigation results for different target groups in an accessible and relevant way. This slightly new focus was introduced to highlight the fact that development-led archaeology can and should also strive to achieve the expressed overall goals of cultural heritage management: 'each and everyone's understanding of, participation in, and responsibility for the own cultural environment'. In his comments, Håkon Glørstad takes issue with that view and instead points out that 
the production of knowledge within development-led archaeology is a self-attaining goal in itself and should not be linked to the various needs of different user groups seeking knowledge. Glørstad argues that the augmented goal of Swedish development-led archaeology is an expression of a market-oriented view that focuses on consumption rather than production. He claims that if the developers' responsibilities include financing the interpretation and dissemination of the results of development-led archaeology, then critical and independent research becomes impossible. He advocates instead for the adoption of the Norwegian system for development-led archaeology. There, according to Glørstad, the primary goal is to secure threatened source material for future research. Therefore the developer pays only for the actual retrieval of the source material, while the interpretative process is the responsibility of the universities.

In our opinion, a source material can never be retrieved in a purely objective manner. The objectives and questions posed by the archaeologist direct the choice of methods and the way in which the excavation is carried out, and are thus decisive for the creation of the archaeological material that is the outcome of the excavation. How an archaeological material is recovered affects future queries and conclusions, both during the excavation and in regard to future research. In other words, no archaeological material is independent of the values prevailing at the time of its retrieval. Since development-led archaeology is carried out for the good of society, it is our duty to ensure that the results will be of the greatest possible use for researchers as well as for planners, state authorities and society in general.

In his comments Joakim Goldhahn discusses a series of problems within Swedish development-led archaeology. His rather discouraging picture corresponds with the views that were put forward at the National Heritage Board conference on 'quality in development-led archaeology' in November 2009. Goldhahn concludes by emphasising that the county administrative boards need additional financial resources in order to ensure that the intentions of the Heritage Act are followed. Even Nathan Schlanger and Kai Salas Rossenbach note the importance of a perceptible State presence to make sure that the high quality of development-led archaeology is sustained. All measures to improve the system, for example to strengthen quality assurance control at various levels, are vital and must be further discussed. The demands that are placed on development-led archaeology today, with 
tender procedures and target group amendments, make it especially imperative that the issue of quality be constantly debated.

Finally, a few words on terms and definitions: In his comments Fredrik Stjernberg discusses the hallmarks of good scientific quality. We agree on how scientific quality should be achieved, generally, and that it is important that the archaeological work be characterized by transparency and openness. However, a clarification is called for. The definitions of the terms 'quality' and 'good scientific quality' which are given in the Regulations must be seen not as universal definitions of these concepts but as clarification of how these terms are to be understood and applied with reference to specific points in the Regulations. Formulation of the more precise connotations of the term 'quality' is a matter for the scientific debate and the various stakeholders. That is the point of our article.

Nathan Schlanger and Kai Salas Rossenbach discuss the best English word with which to translate the Swedish term 'uppdragsarkeologi'. There is a Swedish saying, 'Kärt barn har mainga namn' ('A beloved child has many names') which certainly applies to development-led archaeology. In its early years, at the end of the I960s and beginning of the 70s, the term 'exploateringsarkeologi' (lit. development archaeology) was coined for the archaeological work regulated by the Ancient Monument Act of the time, whereby a developer must finance all the necessary archaeological surveys or excavations he engenders. The expression 'räddningsgräuningar' (lit. rescue excavations) was also used but the term 'development' allowed a desired emphasis on the fact that the archaeological work belonged to the planning process and did not merely involve rescuing a site from bulldozers in a construction project that was already underway. During the course of the I 98 os the terms 'undersökningsverksambet' (lit. investigation services) and 'uppdragsverksambet' (lit. commissioned services) began to appear, perhaps in response to the fact that archaeological surveys and excavations had now become so complex that they represented a special type of enterprise. When translated into English, these concepts were usually grouped under the term rescue archaeology, which was the current term in English-speaking countries during the I970s, 8 os and 9os, and which was also the term used in the Valletta Convention of r992. The term ' $u p p$ dragsarkeologi', which had begun to be used on a more regular basis in Sweden in the 9os, has tended to be translated as 'contract archaeology', the term found in the EAA's Principles of Conduct (I998). In re- 
cent years two new terms have emerged in English-speaking countries - 'developer-funded archaeology' and 'development-led archaeology'. We chose the latter term in our article because we consider that it is a more precise description of archaeological work prompted by land and town development. Nathan Schlanger and Kai Salas Rossenbach consider that 'commissioned archaeology' might be a better term since it makes it clear that an authority has made the decision and given the order that the archaeological work be carried out. The above exposition illustrates the many different terms used over the years, and how the need to update our terminology is associated with changed attitudes to the archaeological work itself and to its purpose. Operating from a small country on the periphery of Europe, we would welcome if initiatives were taken to find a universal term in English for what we in Sweden call 'uppdragsarkeologi'. 

ARTICLES 


\section{THE ESSENCE OF STONE}

\section{Making axes during the Late Mesolithic in Södertörn in east central Sweden}

Mattias Ahlbeck \& Alexander Gill

\begin{abstract}
Greenstone axes produced during the Late Mesolithic in east central Sweden are notoriously dissimilar. Each axe appears to have been given its own special characteristics. These axes were not made into a certain shape by following a technological template. In this article, the authors present the interpretation that people believed the form of an axe was already present in the stone selected for work. Making axes was about releasing essential forms from stones. The essence of stone effectively determined the appearance the axe was destined to have. This is the reason that axes in the region have such variable appearances.
\end{abstract}

Key words: Late Mesolithic, east central Sweden, technology studies, tool production, greenstone axes, pecked axes, polished axes

Explaining how people made things in the past is an area of archaeological research concerned with the development of prehistoric technologies. As a line of investigation the archaeology of technology has successfully managed to establish how techniques were developed and tools used when axes were fashioned, pots produced and iron manufactured.

However, it has become increasingly clear that the investigation of how things were made has predominantly construed technology as a field of knowledge detached from the human world of signification. Even though it has become widely accepted that things were inscribed with meaning in the past, making things is often characterised as a process curiously devoid of any kind of significance. 
Lately, the scope of some studies involved in the explanation of prehistoric technology has widened the field considerably. A growing interest aimed at understanding technology's social dimensions has pointed out that the way things were made was not governed by an abstract rationality readily separable from human affairs. Instead, knowledge of how to make an object was embedded within systems of cultural beliefs and understandings of the world. If we want to gain an insight into why an object was made a certain way, or was given a specific appearance, we need to try to understand the ideas that guided the production process - what it meant to make an object (Lemonnier I986, I992; Pfaffenberger I988, I992; Tilley 1999; Dobres 2000; Barndon 2005a; Ingold 2007).

So far, research into the meaning of making things in Scandinavian prehistory has mainly addressed Iron Age societies and ideas involved in the creation of metal objects (Burström I990; Bergstøl 2002; Rønne 2002; Gansum 2004; Haaland 2004; Barndon 2005b; Goldhahn \& Østigård 2007). Our objective is to follow a similar approach in an attempt to create an understanding of the significance of stone tool production during the Late Mesolithic in east central Sweden.

The analysis of how stone tools were made during the Stone Age in eastern Sweden is in itself a well-established field of research (Callahan I987; Knutsson I988; Callahan et al. I992; Sundström \& Apel I998; Apel 200I). But is it possible to acquire a deeper understanding of the kinds of ideas that guided the creating and shaping of stone tools?

During the excavation of several Late Mesolithic sites on the Södertörn peninsula south of Stockholm in 2005, a large amount of greenstone axes were found (fig. I). Vast quantities of greenstone flakes as well as tools used for axe production were also uncovered (Ahlbeck et al. 2005; Ahlbeck \& Isaksson 2007a). Axes of this kind are quite common in the region. Historically, scholars have shown a great interest in them, and several attempts have been made to sort the axes into chronologically viable typologies (Brøgger I906; Åberg I9I 2; Ekholm I9I 5 ; Lidén 1938 ). Every attempt to do so has been quite unsuccessful, however. Even though the axes were made for thousands of years, dating from the Mesolithic well into the Neolithic, and were given a range of different appearances, older and younger axes cannot readily be distinguished from each other (Welinder 1977; Hermansson \& Welinder 1997).

In this paper we will not be presenting a new axe chronology as we do not believe that it is possible to create one. The problems surround- 
Figure I. Sites in Södertörn mentioned in the text. I) Lisseläng 2, 2) Millingsmossen I, 3) Lässmyran 2, 4) Lässmyran I, 5 ) Lövlund, 6) Jordbromalm \& Lillsjön, 7) Jordbro industriområde, 8) Rudan, 9) Sjövreten, Io) Eklundshov. Light grey: Södertörns present shoreline. Dark grey: Södertörns shore during the Mesolithic, 50 m.a.s.l.

Illustration: Medea $\mathrm{Ny}$ ström Huuva.

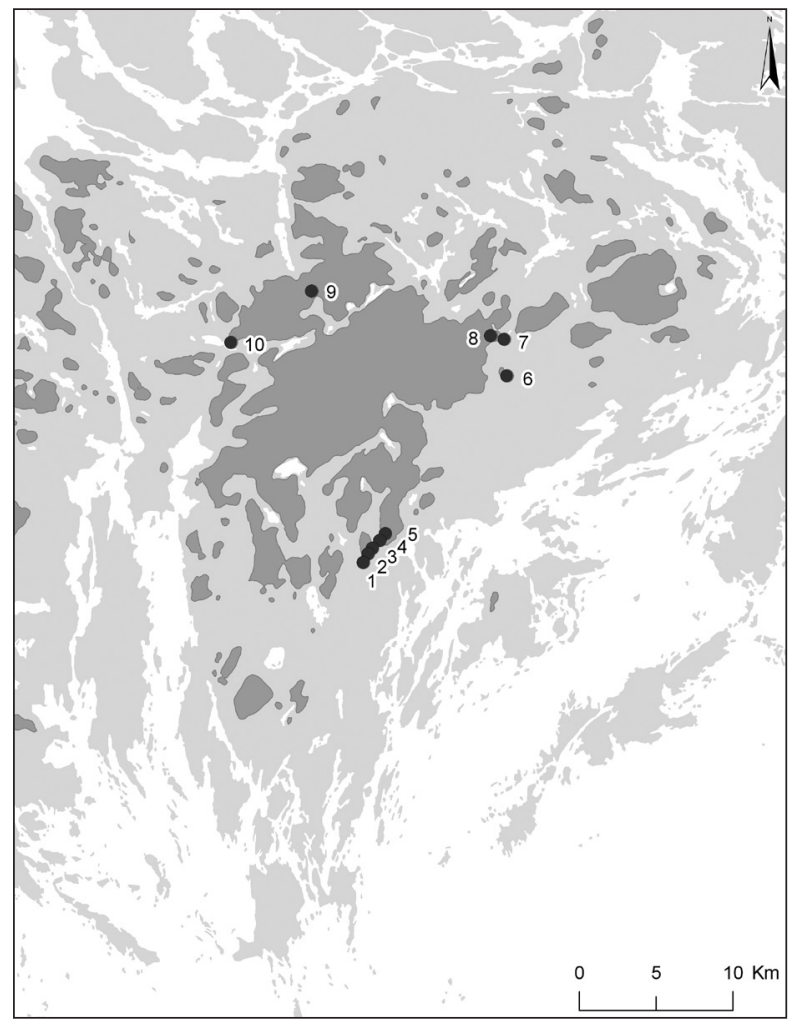

ing the axes do not represent a situation to be solved so much as they inspire an attempt to approach these enigmatic objects from a different perspective. We believe that the fact that they have withstood scientific ordering tells us something about the ideas at play during their production.

In contradiction to a modernistic approach to technology which assumes that technological practice is readily separable from cultural beliefs, we argue that greenstone was believed to contain an inner essence. The art of making an axe was about recognizing a shape already existent in a certain stone and knowing how to release it. The appearance an axe was given was not controlled by its maker's technological proficiency so much as it was guided by the significance ascribed to stone and the beliefs in powers of another kind. If we want to understand why a certain axe was given a specific appearance during the Late Mesolithic we need to appreciate the various beliefs that guided axe makers in their work. 


\section{BACKGROUND}

Most of the area comprising east central Sweden today was submerged during the Mesolithic. The parts above sea level constituted a huge archipelago of thousands of islands in various sizes. Numerous archipelagobased sites have been excavated in recent years and locally made greenstone axes are common in assemblages. These axes were supposedly used for woodwork, roughing out canoes, felling trees, and possibly for clubbing seals (Florin I944; Hermansson \& Welinder I997; Jaksland 2002).

Tools and waste connected to the production of axes have been found at several sites (Lindgren \& Nordqvist I997; Ahlbeck \& Isaksson 2007a). Production materials consist of axe preforms, stone flakes, knapping stones and grinding stones, and have on the whole enabled detailed reconstructions of the axe production process (Guinard \& Vogel 2006:207-2I2; and Sundström \& Apel 1998 for a Neolithic material). The majority of excavated sites have been dated to the Late Mesolithic and it is a confirmed pattern that greenstone axes are inherently dissimilar. They were given various shapes with different cross sections, and were finished by using a combination of different techniques, often pecking and polishing. It is also becoming increasingly clear that different stages of their production were often carried out in separate areas or locations.

Arguably, the tradition of fashioning axes dissimilar in appearance and the spatial separation of different stages of their production are related phenomenon. Late Mesolithic smiths appear to have shaped and finished axes according to their own personal tastes. At the same time a growing body of evidence suggests that making axes, or at least axe preforms, was delimited to certain sites in a wider landscape setting or specific areas within a settlement, signalling an activity regulated by specific norms or traditions.

The various shapes given to greenstone axes indicate that the intention of individual stone-smiths might not have been the creation of axes modelled in a formalised manner by using a technological template, as seems to be the case with certain Neolithic axes. We want to propose instead that the creation of these objects was guided by a different approach. Methodological considerations were not primary but secondary when making a Late Mesolithic axe.

\section{MAKING AXES}

The greenstone axes of east central Sweden were made by combining 
several production methods. A simple model illustrating the general stages is presented in figure 2 .

Three main techniques were used: knapping, pecking and polishing. These methods do not only create a range of different characteristics in the axes themselves, but also produce waste materials as well as a variety of necessary tools. This enables the production process to be mapped spatially through an analysis of where the production tools and stone waste were deposited.

The first stage of making an axe was the procurement of raw material. Appropriate stone was probably quarried from suitable outcrops.

At present, only three sites where greenstone might have been extracted are known in east central Sweden. The first, Ullevi Klint in the province of Närke, is of uncertain age (Johnsen \& Welinder I980; Welinder 1985). A second, north of the Mesolithic site of Sjövreten in Södertörn, has been identified, but it is unclear whether greenstone was actually quarried or not (Kars et al. 2009:I6). A third location has been identified at Rudan in Södertörn. The quarry itself has not been excavated but an adjacent site is most certainly from the Late Mesolithic (Ahlbeck \& Isaksson 2007b).

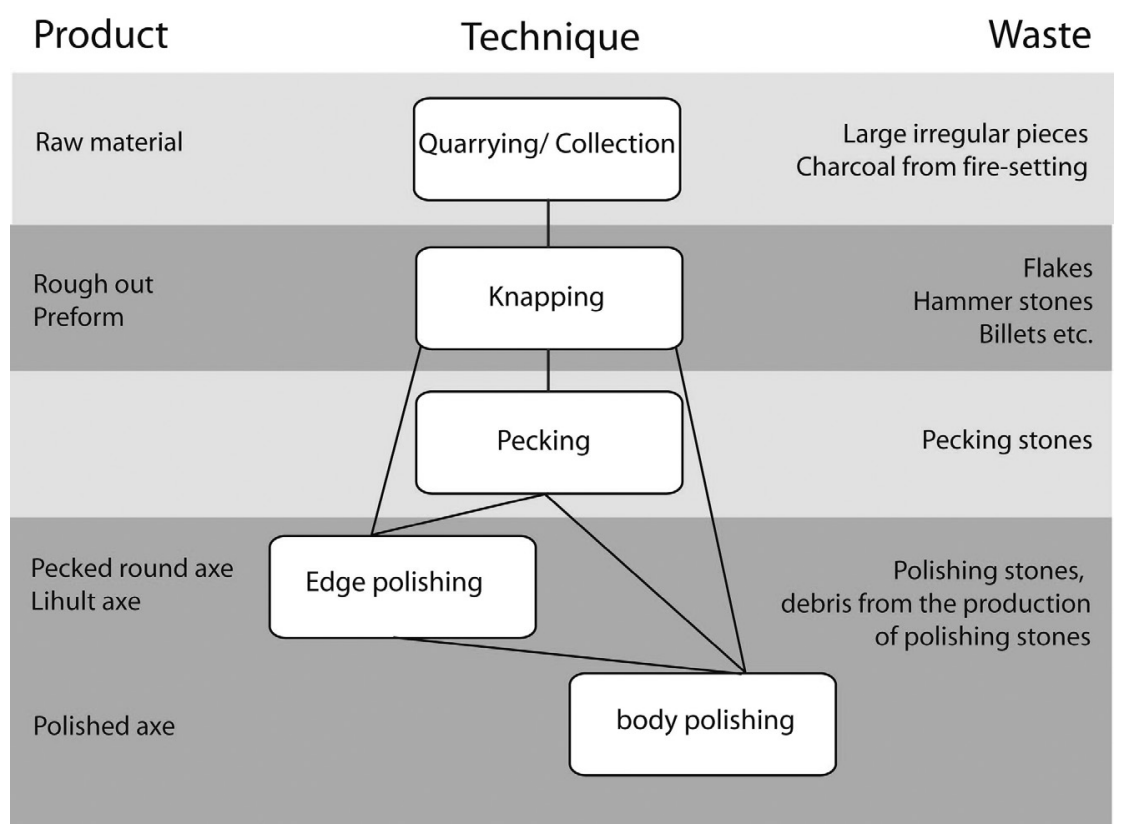

Figure 2. A basic model of the production process. 
Waste produced when quarrying stone from such an outcrop can consist of large irregular pieces. Slabs of burnt stone might be present if fire-setting was used to split rock, a method identified at the Bømlo and Stakaneset quarries in Norway as well as at Sélédin in France (Alsaker I987:40 ff.)

Alternatively, boulders deposited by glacial movement on the leeside of protruding bedrock could have been collected or quarried. Certain beaches where boulders were collected from deposits washed out by the sea are another possible source.

Knapping a rough-out is the second stage of production. As a technique for finishing axes, it is known in different kinds of rock early in the Mesolithic of southern Finland (Núñez I998:I09) as well as in south Scandinavian flake and core axes of flint. In east central Sweden, however, greenstone objects made solely by knapping are probably preforms, not finished axes.

Knapping greenstone involved numerous stages, from rough-outing to pre-forming. This technique can be identified by flakes of greenstone, rough-outs, and hammer stones. The tool kit and consequently the technological options were probably much greater than is presently visible in the archaeological record. The renowned stone-smith Erret Callahan is reported to have used a heavy billet for coarse knapping. When working with greenstone, which is a relatively soft material, an antler or wooden billet was preferred. At later points in the knapping process Callahan switched to a punch (Sundström \& Apel I 998:I63ff). Billets and punches of organic materials were thus probably used during knapping, and in excellent preservation conditions it ought to be possible to find tools of this kind.

After knapping, stone-smiths often chose to continue the production process by pecking the preform. The technique can be identified in source materials by the tools that were used, in this case pecking stones used to fashion a shape out of the preform. Unlike hammer stones two kinds of pecking stones were probably used. Callahan used a hard spherical or oval stone during his experiments, but ethno-archaeological surveys show that stones with prolific edges or ridges also work well. The functional surfaces in this case are the protruding parts of the stone (Pétrequin \& Pétrequin I993). Numerous discarded pecking stones of this kind were found during the excavations on southern Södertörn. As the working edges were worn down the stones sometimes ended up rounded (Ahlbeck \& Isaksson 2007a:I6f). 
It was not until the preforms were polished during the fourth stage of production that proper greenstone axes were fashioned. In some cases polishing took place directly after knapping, but more often the preforms had previously been pecked. Sometimes polishing was confined to the edge of the axe, in other cases an axe was polished all over. Polishing removed visible scars and traces of pecking in various degrees. Thus, techniques used in earlier stages of production are not always possible to identify later on.

Besides polished axes, archaeological source materials from the fourth stage of work consist of polishing stones and flakes of sandstone that are remnants from the production of polishing stones. Debris from the production of polishing stones has been found at the site of Millingsmossen I as well as at Lässmyran 2 in Södertörn (Ahlbeck \& Isaksson 2007a).

Preforms were also abandoned during different stages of the production process. It was not until a preform was furnished with an edge that it became a fully functional axe. Therefore, two main types of preforms can be identified according to this interpretation of the production process: knapped performs, and knapped and pecked preforms.

Our description of the production process is intentionally simple. Within it lie many opportunities for variation. A preform made by knapping, for example, can be given a triangular cross section, as exemplified by the Lihult axe, a pointed oval shape as in the Limhamn axe, or a rectangular cross section as in thin-butted axes. When pecking is added we also see axes with round and oval cross sections, as is the case with the classic pecked axes. There is coordination among the technique, method and shapes of finished axes with their various characteristics. Axes were not made by following a predetermined reduction process and a strict set of rules. They were made by combining a small number of methods in a rather playful and undetermined manner.

\section{WHEN WERE THEY MADE?}

In Denmark, Scania and along the west coast of Sweden the chronology of greenstone axes appears to be well understood. Pecked round axes (Sw. trindyxor) occur from the Early or Middle Mesolithic up until the Middle Neolithic (Lindgren \& Nordqvist I997:58ff; Sørensen 2007:I 84). In western Sweden the Lihult axe was introduced around $5800 \mathrm{BC}$ and was in use at the same time as the pecked round axe. The Lihult style of axes did not spread to eastern or southern Sweden 
(Lindgren \& Nordqvist 1997:58ff). In south-east Norway its sibling, the Nøstvet axe, was introduced around 6000 BC. This type was, as in Sweden, preceded by the pecked round axe but during the period 6000$5700 \mathrm{BC}$ it was also accompanied by a partly pecked axe (Glørstad 2004:2Iff). In Denmark and Scania pecked round axes were eventually replaced by the Limhamn axe that appeared around $4500 \mathrm{BC}$ (Sørensen 2007:I 84). In Finland only knapped axes were used during the early stages of the Mesolithic. In southern Finland axes with completely polished bodies emerged around 6500 BC (Matiskainen I989:389).

In east central Sweden the situation is not as clear. As was the case in south Scandinavia and along the western coast of Sweden, pecked round axes emerged early on and were made and used for a very long time. At Eklundshov pecked axes from the Middle Mesolithic have been found (Gustafsson et al. 2009), while the youngest pecked axes in the region are from the Middle Neolithic. Around 6000 BC an abundance of polished axes with different characteristics began to emerge (Lindgren \& Nordqvist I997). Amongst the earliest examples is an axe dated to 6500 BC from Vittersjö in the province of Gästrikland (Björck et al. 2000).

As mentioned earlier, several scholars attempted to construct a typology of greenstone axes during the first half of the twentieth century. In areas where flint does not occur regularly, as is the case in east central Sweden, the establishment of an axe typology promised the possibility of reconstructing colonization processes and the expansion of settlement patterns during the Stone Age. Early research into the Stone Age of the region was not aware of the early time point of its colonization and as a consequence axes that looked like they were from the Late Stone Age, with features such as narrow sides or completely polished bodies, were classified as local variations of Neolithic axes - axes that we know today are from the Mesolithic.

One of the assumptions of early scholars was that changes in the ways axes were made supposedly represented some kind of cultural development (Ekholm I9I 5). Polishing was in this case believed to be a younger trait and an example of technological progress. However, as we have already discussed, every technique used in making a greenstone axe - knapping, pecking and polishing - was already in use when the oldest, pecked, round axes were made in the region, albeit that polishing was confined to the axes edges.

The advent of greenstone axes with more or less completely polished bodies should not be considered a transitional type that eventu- 
ally ended up becoming a polished Neolithic type, as we now know that these axes were of a considerable age. Differences in appearance do not reflect different levels of technological know-how, but rather divergent aesthetic or functional considerations.

What happened during the later stages of the Mesolithic in east central Sweden is that axe-smiths began using established techniques to make a range of axes with varying appearances in a manner that clearly separates this region from the surrounding areas.

\section{A MIXTURE OF SHAPES}

A general characteristic of Late Mesolithic greenstone axes from east central Sweden is thus their diversified appearance. The same cannot be said of axes from surrounding regions, like the Limhamn or the $\mathrm{Li}$ hult axe, which are valid chronological types.

If we consider a selection of greenstone axes from southern Södertörn, like those in figure 3 , it becomes clear that their heterogeneous appearance is not a question of chronology. Instead axes of the same age are inherently different.

In figure 3, the upper three objects are axe preforms. The uppermost is an example of how a preform for a "classic" pecked axe with a rounded oval cross section looks. Below the preforms are two completely polished axes. To the right is an axe that has been knapped and partly pecked. Polishing has been carried out along its edge as well as in uneven intervals over its body.

Different parts of a single axe are usually worked in different ways. The broad sides can be polished on one side and pecked on the other. In other instances the same broad side can be polished in one area and pecked in another. The axes butts were given different shapes, some only knapped, others rounded or pointed. The cross section of the axes often diverges at different points of the body. The same axe can be facetted on one narrow side and round or flat on the other. Axes with a totally asymmetrical cross section are common.

Certainly, some of the different traits can be explained as functional, but at the same time it is clear that the notion "form follows function" is not valid as there appears to be so many forms and not enough known functions. Another possibility is that the mixture of shapes could be an effect of how the axes were used and progressively worn down throughout their lifespan, a notion, however, that is somewhat contradicted by the circumstance that even the largest axes have very 


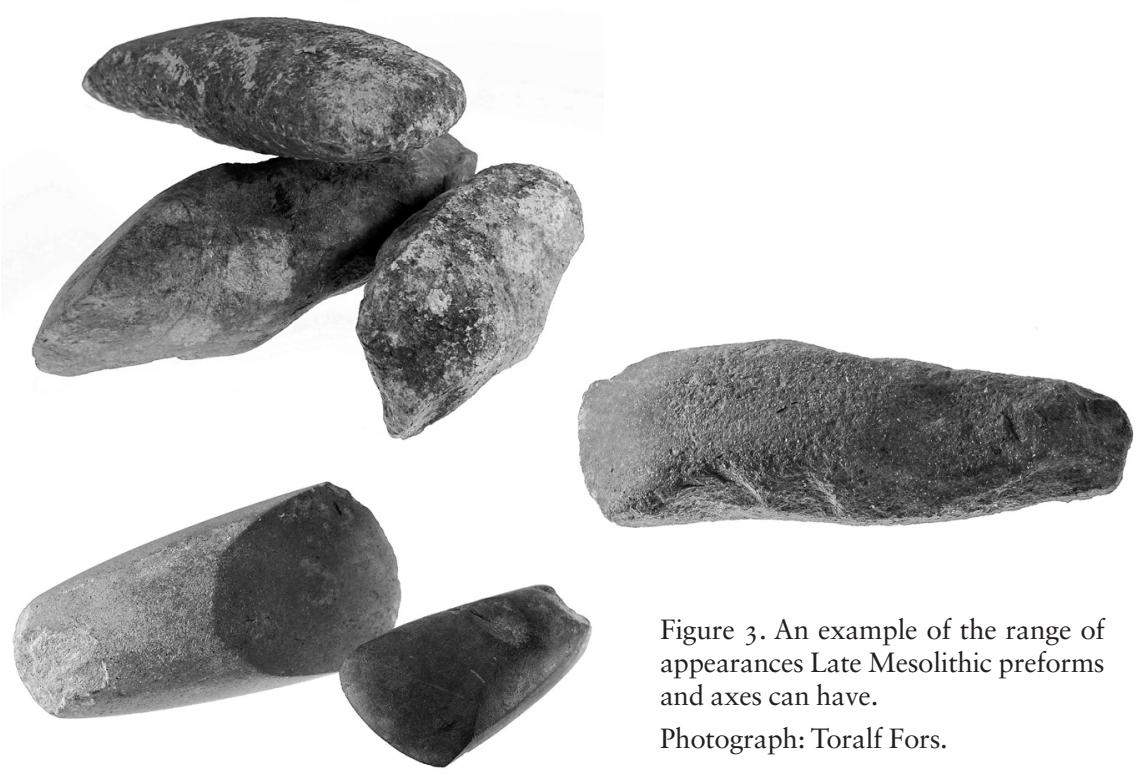

different shapes. Another way of explaining the axes' heterogeneity needs to be proposed.

Greenstone was the most common material used for making axes in Södertörn. It was, however, not the only material. Axes made out of other sorts of stone have been found as is the case with assemblages from the site of Jordbro industriområde, kept at the Museum of National Antiquities in Stockholm. An impression of individual difference is in this case strengthened by the choice of a variety of raw materials.

The playful shaping of axes made and used in the Late Mesolithic archipelago corresponds to the situation at Motala on the Mesolithic mainland. No two axes appeared the same, but were rather inherently unique. Tom Carlsson (2007:I85) explains the variation by stating that stone-smiths seem to have been concerned with emphasizing the colours, patterns, and other essential qualities previously concealed within the stone.

It appears to be the case that axe makers during the Late Mesolithic were not primarily following a predetermined reduction process of a kind that is recognizable in many Neolithic materials. The creation of Late Mesolithic greenstone axes was governed by a different approach, which is why they were given such diverse appearances.

\section{THE SPATIAL DIMENSIONS OF AXE MAKING}

As we have already pointed out, the production of greenstone axes fol- 
lowed three general steps: I) the procurement of raw material; 2) the production of preforms by knapping and pecking; 3) finishing axes by polishing.

During the winter of 2008 we spent a couple of weeks examining assemblages from several Mesolithic sites on northern Södertörn that were stored in the Museum of National Antiquities in Stockholm. It soon became clear that axes had not been produced at every excavated site (also Lindgren \& Nordqvist 1997:70). At some sites production was restricted to a certain area (Gustafsson et al. 2009). At others production was restricted to certain stages, as is the case at Jordbro industriområde and Jordbromalm where only polishing, and possibly pecking, but no knapping took place. The same pattern was also identified at the nearby site of Lillsjön, which we excavated ourselves in the summer of 2008 (Ahlbeck \& Gill 2010).

The analysis of source materials from southern Södertörn tends to confirm this general pattern; that is, when axes were made at a site only certain stages of production usually took place. At Millingsmossen I knapping was the only stage identified, while source materials from Lövlund indicate that pecking and polishing were carried out on preforms that clearly had been knapped somewhere else. At Lässmyran 2, knapping, pecking, and polishing took place but hardly any finished or broken axes were found. Complete axes had apparently been removed from the site and put to use elsewhere. In this case the whole site appears to have been a special workshop. Other possible workshops in Södertörn as well as in surrounding regions have previously been identified and described as special "axe sites" (Carlsson I998:29ff).

Lisseläng 2 is another site where the whole production process was identified, with the exception of quarrying raw material. In this case traces of the production process were spread over the site in an erratic manner, indicating that different stages were not carried out simultaneously but instead at different occasions. Radiocarbon dates from the site indicate that it was used sporadically for hundreds of years (Ahlbeck \& Isaksson 2007a:I65f).

The tendency towards a spatial separation of production stages has also been identified in the northern parts of the Mesolithic archipelago, as exemplified by the Stormossen sites in the province of Uppland. Here, preforms were knapped at Stormossen I while polishing was carried out at Stormossen 4 (Guinard \& Vogel 2006:2I2). 
As can be gathered, numerous sites located in an archipelago environment during the Mesolithic have been excavated in the last couple of decades. It has become increasingly clear that sites in the archipelago were similar to each other as well as different. The spatial separation of production stages indicates that these traits have to be understood as part of a mutual process of some kind.

\section{TWO DIFFERENT APPROACHES TO TECHNOLOGY}

Sven-Eric Liedman (I997) has described two fundamentally different ways of understanding technology. During Antiquity and the Middle Ages the materials themselves were emphasized. A basic idea was that a certain material contained an inner quality or essence that a skillful craftsman had the ability to call forth. Stone, wood and metal were, just like acorns or seeds, believed to hold their own perfect form within them. Craftsmen and artists were not different professions as is the case today. A good craftsman or artist had the aptitude to realize the ideal form contained in a material.

This understanding of technology differs greatly from a modern approach rooted in Enlightenment ideas. Nowadays technology is more about how tools are used on materials, and how techniques are applied to materials, than about the materials themselves. The notion that a material contains its own inner essence has been abandoned by artists as well as craftsmen (Liedman I997). Material has become an object with characteristics that science can quantify and calculate. Today, technology emphasizes the abstract principles that govern how objects are made rather than the things or materials themselves. Transferring technological knowledge from one generation to another is about learning a body of more or less theoretical scientific know-how, whereas in the past the passing of knowledge from master to apprentice entailed conveying a sense of the kinds of forms that were present in a raw material as well as ways of bringing them forth.

Both of these approaches can be identified in Scandinavian Stone Age archaeological research. An example of a modernistic approach is Jan Apel's thesis Daggers, knowledge \& power (200I) in which the manufacture of south Scandinavian flint daggers during the Late Neolithic is probed.

Apel treats technology as a level of knowledge applied to a raw material and explains that knowledge of how to make a dagger was probably restricted to certain groups in society. Making a dagger required 
skills that could not be acquired without special training and they might have been taught within systems of apprenticeship.

The production process, from the procurement of raw material at a natural source to the final finishing of a dagger, is claimed to include simple as well as more complicated stages. By means of a spatial analysis Apel argues that production stages of varying difficulty were carried out at different kinds of locations. Simpler stages were carried out at a distance from the settlements whereas more difficult ones were performed in or near the settlements themselves.

In Apel's opinion, the spatial distribution of different stages of production reflects how simpler stages, which were easy to copy, were carried out in locations where it would have been difficult for outsiders to gain insight into the process. On the other hand, stages that were more complicated and almost impossible to copy were performed in more public locations. In this way important technological knowledge could be kept secret. At the same time, the system maximized the prestige of the flint-smiths (Apel 200I).

Jimmy Strassburg's study of south Scandinavian thin-butted flint axes from the Early Neolithic (Strassburg I998) exemplifies the other approach to technology. Here, technology is understood to be something inseparable from cultural beliefs. The human life cycle from birth to death is used as a metaphor to understand how an axe proceeds from production to disposal. Flint is portrayed as full of life, with inherent qualities. The life of a thin-butted flint axe is followed from its birth in a quarry, through the formative years as a child in the caring hands of a flint-smith, in work as a mature grown-up, until death when it breaks or is discarded. In Strasburg's vision the creation of an axe is more about knowing how to emancipate life from a stone than how to knap flint into a functional tool.

Worth noting is that Strassburg also identifies a spatial distribution of different stages of the axe-making process. This separation is not claimed to reflect an attempt to keep knowledge secret, however. Instead, he presents the idea that people sought to separate a material from other spheres of life because it had inherent qualities regarded as potentially dangerous.

In this case the spatial patterning of different stages of production is interpreted as a reflection of the culture-specific meanings inscribed in stone during the Early Neolithic - understandings that structured how stone itself was handled. 
Strassburg's work has connections to a steadily growing field of landscape archaeology where landscape is understood to consist of a palimpsest of places inscribed with special significance. Mountains, rivers, islands and forests - the elements of landscape - are approached as places believed to have been created by the actions of gods or ancestors in a mythological past (Tilley I994).

Quarries were, in this case, not just sites where important raw materials could be collected, but places where people may have believed something divine had happened in the past. Perhaps it was a mythical event that created the greenstone itself, imbuing it with its essence.

The beach ridge Järavallen in the province of Scania is an example of a natural feature that appears to have been construed in such a way. The beliefs that rendered the ridge comprehensible in the past appear to have affected the way in which flint nodules procured from it were handled (Högberg 2002).

Collecting or quarrying stone from a location enshrouded in mythological beliefs might not have been a straightforward affair at all. If suitable stone for making axes was believed to contain a force of some kind, collecting it as well as working it might have been considered a risky business indeed.

Apel's and Strassburg's studies are examples of two possible ways of approaching the production of greenstone axes during the Late Mesolithic of east central Sweden, and two different ways of interpreting a spatial separation of different production stages. In Apel's case, the basis for his interpretation is presented as the rational decision to use knowledge to gain power. The same kind of division in Strassburg's example is explained by culture-specific beliefs in powers of another kind.

As discussed above, the production of greenstone axes does not appear to have been guided by a formalized template. The apparent absence of a specific set of orderly rules means that the spatial separation of different stages of axe making might not reflect a desire to secretly and jealously guard know-how.

In this case the separation is possibly a reflection of specific beliefs held during the Mesolithic about the properties of stone and how the act of creating axes ought to be handled.

\section{THE ESSENCE OF STONE}

Summing up, we want to define a difference between an object's shape and its form. For example, if the shape of a nail was given to it by the 
machinery that produced it, its form was already present as a possibility in the iron ore it was made of. Whilst the shape of an oak can hardly be identified in an acorn, its potential form is on the other hand easily recognized. Form is about becoming whereas shape is something created.

So, when archaeological research debates thin-butted Neolithic axes, it is debating the shape that a specific material was given via a chaine d'operatoire geared at producing such a shape. In short, our argument is that the Late Mesolithic axes of east central Sweden did not have a shape - they had a form.

Greenstone was a coveted material during the Mesolithic, with special qualities that allowed it to be formed into a very useful tool. As an axe, greenstone had become a mighty thing. It was powerful enough to rework trees into canoes as well as to take a life. The axe was a catalyst in the transformation of things from one state of being into another.

With its transformative characteristics it acted within two diametrically opposed and possibly dangerous liminal zones. Bringing forth the canoe from its potentiality in the tree, it brought fulfillment. Bringing down a human being, it brought deadly destruction. This is the kind of potential found slumbering in greenstone. It was not only a raw material one could shape into a tool, but also a bringer of life or death waiting to be brought into existence.

A prerequisite when making an axe is to know how to work the stone. If greenstone was believed to have an essence of divine qualities then the ability to transform it into an axe might have involved knowledge of powers of ancestral or mythical provenance. Working forth the form of such powers might have been considered a dangerous endeavor. If this was the case, then the spatial separation of facets of axe production from the settled, or otherwise sensitive, places was probably a sensible thing to do.

Late Mesolithic axes from east central Sweden have different forms. It is very clear that they were not made as copies in accordance with a certain type. If Mesolithic axe makers believed that the material they were working contained a powerful inner essence and a form they were called upon to materialize, then the wide range of different forms becomes clear; it was not up to the smiths themselves to decide what form an axe would have. The form was already present in the stone at hand. It was the notion of a presence already in the stone that guided the axe-smith's hands and choice of techniques, rather than a set of given technological rules. 
Indeed, a couple of instances indicating that axes might have been considered objects with special powers rather than mere functional tools have been recorded. At Sjövreten on northern Södertörn, two axes were found deposited in a position next to each other (Welinder I977). At Lövlund a pair of axes standing side by side was found with the axe blades thrust into the ground (Ahlbeck \& Isaksson 2007a:I 59). At Rudan a single axe was found in a similar circumstance. It also had its blade thrust into the ground (Ahlbeck \& Isaksson 2007b). Many axes found on Mesolithic sites throughout the region also appear to have been intentionally broken (Carlsson I998:32). In Neolithic contexts equivalent actions have been interpreted as attempts to neutralize an axe's power (Karsten I 994:I7Iff).

This kind of reasoning, that the form of an axe was already a given, seems at first glance to differ from the way in which many Neolithic axes were produced in the region. A Neolithic idiom is, for example, identifiable in the measurements of thin-butted axes, where axe-smiths seem to have been making copies of an already existing shape. However, this kind of reasoning might not have been a Neolithic trait in central Sweden. In a paper explaining how Early Neolithic greenstone axes were made in the region, Lars Sundström and Jan Apel show that they were produced by using a different method than that of the south Scandinavian thin-butted axes of flint (Sundström \& Apel I998).

In the case of south Scandinavian axes, preforms were produced

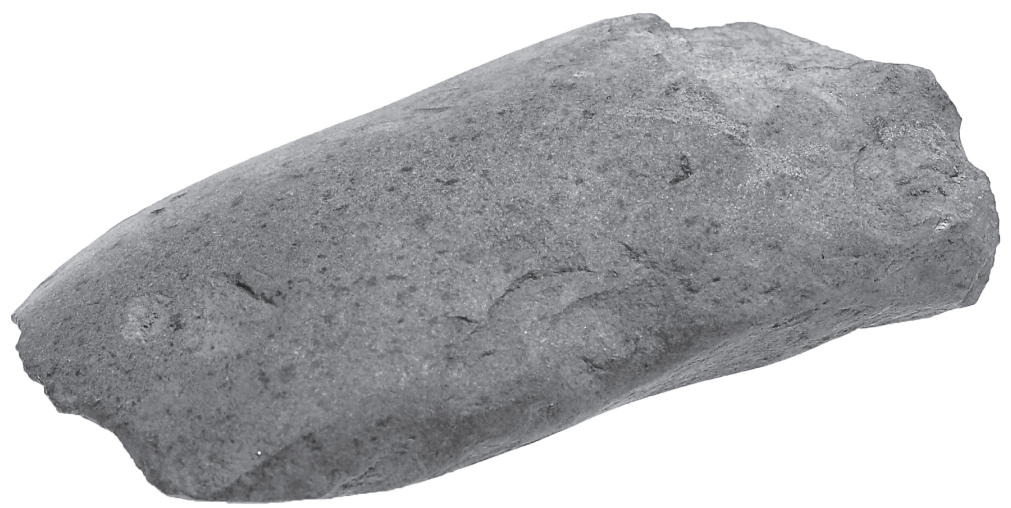

Figure 4. An early Neolithic axe from Lisseläng 2 made by the double ridge method. The axe was found in a posthole dated to $3800-3460 \mathrm{BC}$.

Photograph: Toralf Fors. 
using a square axe method, whereas in east central Sweden preforms were made using a double ridge method (fig. 4). What thus appears to be the case is that a certain way of producing axes was not imported to east central Sweden at the onset of the Neolithic, but rather a new notion of the possible forms an axe could have. Pecked round axes were made well into the Middle Neolithic in the region, indicating that ideas concerning the essential qualities of stone were not only restricted to the Mesolithic.

In this paper we have presented our understanding of the ideas that guided the creation of greenstone axes. Our conclusion is that people held the belief that greenstone had essential qualities, the material itself being loaded with meaning. Using this approach we can begin to grasp why these axes were given various shapes and why their production sequence tends to be spatially isolated.

\author{
Mattias Ahlbeck, Arkeologikonsult, \\ Box 20, I94 2I Upplands Väsby, Sweden \\ Alexander Gill, Arkeologikonsult, \\ Box 20, I94 2I Upplands Väsby, Sweden
}

\title{
References
}

Ahlbeck, M. \& Gill, A. 2010. Lillsjön: en senmesolitisk lokal med inslag frän neolitikum och äldre järnålder på fastigheten Jordbromalm 4:2. Särskild arkeologisk undersökning av Raä 233, Österhaninge socken, Haninge kommun, Stockholms län. Rapporter från Arkeologikonsult 2010: 2197. Upplands Väsby: Arkeologikonsult.

Ahlbeck, M. \& Isaksson, M. 2007a. Riksväg 73. Slutundersökningar Rä̈ 661, 663, 664, 665 och 666, Ösmo sn, Södermanland. Särskilda arkeologiska undersökningar längs Riksväg 73, Överfors-Västnora. Rapporter från Arkeologikonsult 2007:2037. Upplands Väsby: Arkeologikonsult.

Ahlbeck, M. \& Isaksson, M. 2007 b. Rudan I:2. Arkeologiska förundersökningar av stenåldersboplatserna Rä̈ 263, 264, 590:I och 590:2, Österhaninge sn, Södermanland. Rapporter från Arkeologikonsult 2007:260. Upplands Väsby: Arkeologikonsult.

Ahlbeck, M., Isaksson, M., Fors, T. \& Risberg, J. 2005. Riksväg 73. Förundersökningar Överfors - Västnora. Rapporter från Arkeologikonsult 2005:I09I. Upplands Väsby: Arkeologikonsult.

Alsaker, S. I987. Bømlo - Steinalderens råstoffsentrum på Sørvestlandet. Bergen: Historiskt museum.

Apel, J. 200I. Daggers, Knowledge \& Power. The Social Aspects of Flint-Dagger Technology in Scandinavia $2350-1500$ cal BC. Uppsala: Department of Archaeology and Ancient History. 
Barndon, R. 2005 a. Sparks of Life. The Concept of Fire in Iron Working. Current Swedish Archaeology. Vol I 3. Pp. 39-57.

Barndon, R. 2005b. Metall og myter - magi og transformasjon. Refleksjoner omkring den norrøne smedens kunnskap og identitet i et komparativt perspektiv. Primitive tider. Vol. 8. Pp. 6I-75.

Bergstøl, J. 2002. Iron Technology and Magic in Iron Age Norway. In: Ottway, B. S \& Wager, E. C. (Eds). Metals and Society. Papers from a session held at the European Association of Archaeologists Sixth Annual Meeting in Lisbon 2000. Pp. 77-82. BAR International Series I061. Oxford: Archaeopress.

Björck, M., Björck, N. \& Martinelle, K. 2000. Vittersjö. En mesolitisk boplats. Arkeologisk undersökning Rä̈ 65, Ockenbo socken, Gästrikland I 994 och I 995 . Rapport Länsmuseet Gävleborg I999:09. Gävle: Länsmuseet Gävleborg.

Brøgger, A.W. I906. Studier over Norges stenalder. Christiania: Videnskapsselskapets skrifter.

Burström, M. I990. Järnframställning och gravritual. En strukturalistisk tolkning av järnslagg i vikingatida gravar i Gästrikland. Fornvännen. Vol. 85 . Pp. 26I-27I.

Callahan. E. I987. An evaluation of the lithic technology in Middle Sweden during the Mesolithic and Neolithic. Uppsala: Department of Archaeology and Ancient History.

Callahan, E. Forsberg, L., Knutsson, K., \& Lindgren, C. I992. Fakturbilder. Kulturhistoriska kommentarer till det säregna sönderfallet vid bearbetning av kvarts. Tor. Vol 24. Pp. 27-63.

Carlsson, A. I998. Tolkande arkeologi och svensk forntidshistoria. Stenåldern. Stockholm: Department of Archaeology, Stockholm University.

Carlsson. T. 2007. Mesolitiska möten. Strandvägen, en senmesolitisk boplats vid Motala ström. Lund: Lund University.

Dobres, M-A. 2000. Technology and social agency: outlining a practice framework for archaeology. Oxford: Blackwell.

Ekholm, G. I9I 5. Studier i Upplands bebyggelsehistoria. I. Stenåldern. Uppsala: Filosofiska fakulteten i Uppsala.

Florin, S. I944. Stenåldersbebyggelsen i östra Södermanland. Sörmlandsbygden. Vol. I3. Pp. 33-48.

Gansum, T. 2004. Role the Bone - from Iron to Steel. Norwegian Archaeological Review. Vol. 37. Pp. 4I-57.

Glørstad, H. 2004. Kronologiske resultater fra Svinesundsprosjektet. In: Glørstad, H. (Ed.). Oppsumering av Svinesundprosjektet. Bind 4. Pp. 2I-46. Oslo: Universitetets kulturhistoriske museer.

Goldhahn, J. \& Østigård, T. 2007. Rituelle spesialister i bronse- og jernaldern. 2. Transformatøren: Ildens mester $i$ jernalderen. Göteborg: Institutionen för arkeologi.

Guinard, M. \& Vogel, P. (Eds.) 2006. Stormossen. Ett senmesolitiskt boplatskomplex $i$ den yttre uppländska skärgården. SAU Skrifter 20. Uppsala: Societas archaeologica Uppsaliensis.

Gustafsson, P., Lindgren, C., Risberg, J. \& Karlsson, S. 2009. The Eklundshov Site. In: Åkerlund, A., Olson, E., Gustafsson, P. \& Miller, U. (Eds.) Södertörn Interdisciplinary Investigations of Stone Age Sites in Eastern Middle Sweden. Pp. I-I I I. Stockholm: Riksantikvarieämbetet.

Haaland, R. 2004. Technology, Transformation and Symbolism: Ethnographic Perspectives on European Iron Working. Norwegian Archaeological Review. Vol. 37. Pp. I-I9. 
Hermansson, R. \& Welinder, S. I997. Norra Europas trindyxor. Östersund: Mitthögskolan.

Högberg, A. 2002. Production Sites on the Beach Ridge of Järavallen. Aspects on Tool Preforms, Action, Technology, Ritual and the Continuity of Place. Current Swedish Archaeology. Vol Io. Pp. I37-I62.

Ingold, T. 2007. Materials against materiality. Archaeological Dialogues. Vol I4. Pp. I-I6.

Jaksland, L. 2002. Berget I - en senmesolitisk boplass med hyttetuft. In: Glørstad, H. (Ed.). Svinesundprosjektet. Bind I. Utgravninger avsluttet i 200 I. Pp. 35-72. Oslo: Universitetets kulturhistoriske museer.

Johnsen, B. \& Welinder, S. I980. Ett neolitiskt stenbrott i Kilsbergen. Från Bergslag till bondebygd. Vol 34. Pp. I 58-I6I.

Kars, E., Olsson, E. \& Kars, H. 2009. Greenstone Axes - Local Manufacture or Import? In: Åkerlund, A., Olson, E., Gustafsson, P. \& Miller, U. (Eds.) Södertörn Interdisciplinary Investigations of Stone Age Sites in Eastern Middle Sweden. Pp. I-53. Stockholm: Riksantikvarieämbetet.

Karsten, P. 1994. Att kasta yxan i sjön: en studie över rituell tradition och förändring utifrån skånska neolitiska offerfynd. Stockholm: Almqvist \& Wiksell International.

Knutsson, K. I988. Making and using stone tools: the analysis of the lithic assemblages from Middle Neolithic sites with flint in Västerbotten, northern Sweden. Uppsala: Societas archaeologica uppsaliensis: Department of archaeology.

Lemonnier, P. I986. The Study of Material Culture Today: Toward an Anthropological theory of Technical Systems. Journal of Anthropological Archaeology. Vol. 5. Pp. I47-I 86.

Lemonnier, P. 1992. Introduction. In: Lemonnier (Ed.). Technological choices: Transformation in material cultures since the Neolithic. Pp. I-35. London: Routledge.

Lidén, O. 1938. Sydsvensk stenålder belyst av fynden på boplatserna i Jonstorp. I. Skivyxekulturen. Lund.

Liedman, S-E. I997. I skuggan av framtiden. Modernitetens idéhistoria. Stockholm: Bonnier.

Lindgren, C. \& Nordqvist, B. I997. Lihultyxor och trindyxor - om yxor av basiska bergarter i östra och västra Sverige under mesolitikum. In: Larsson, M. \& Olsson, E. (Eds.). Regionalt och interregionalt. Stenåldersundersökningar iSyd-och Mellansverige. Pp. 57-72. Stockholm: Riksantikvarieämbetet.

Matiskainen, H. I989. The Chronology of the Finnish Mesolithic. In: Bonsall, C. (Ed.). The Mesolithic in Europe, III International Mesolithic Symposium. Pp. 379-390. Edinburgh: John Donald Publishers Limited.

Núñez, M. I998: Slates, the "plastics" of Stone Age Finland. In: Holm, L. \& Knutsson, K. (Eds.). Proceedings from the Third Flint Alternatives Conference at Uppsala. Pp. I05-I24. Uppsala: Department of Archaeology and Ancient History.

Pétrequin, P. \& Pétrequin, A.M. 1993. Écologie d'un outil: la hache de pierre en Irian Jaya (Indonésie). Paris: Centre de Recherches Archéologiques.

Pfaffenberger, B. I988. Fetishised objects and humanised nature: towards an anthropology of technology. Man. Vol. 23. Pp. 236-252.

Pfaffenberger, B. I992. Social Anthropology of Technology. Annual Review of Anthropology. Vol. 21. Pp. 49 I-516.

Rønne, O. 2002. Smeden i jernalder-ildens hersker. Primitive tider. Vol. 5. Pp. 55-63. 
Sørensen, S. 2007. Limhamn axes in Denmark. In: Hård, B., Jennbert, K. \& Olausson, D. (Eds.). On the Road: Studies in Honour of Lars Larsson. Pp. I84-I 87. Stockholm: Almqvist \& Wiksell International.

Strassburg, J. I998. Let the "Axe" Go! Mapping the Meaningful Spectrum of the "Thin-Butted Flint Axe". In: Andersson, A.C., Gillberg, A., Jensen, O.W., Karlsson, H., Rolöf, M.V. (Eds.) The Kaleidoscopic Past. Pp. I84-187. Göteborg: Department of Archaeology.

Sundström, L. \& Apel, J. I998. An Early Neolithic axe production and distribution system within a semi-sedentary farming society in Eastern Central Sweden, c. 3500 BC. In: Holm, L. \& Knutsson, K. (Eds.). Proceedings from the Third Flint Alternatives Conference at Uppsala. Pp. I 55-I92. Uppsala: Department of Archaeology and Ancient History.

Tilley, C. I994. A Phenomenology of Landscape: places, paths and monuments. Oxford: Berg.

Tilley, C. I999. Metaphor and Material Culture. Oxford: Blackwell.

Welinder, S. I977. The Mesolithic Stone Age of Eastern Middle Sweden. Stockholm: Antikvariskt arkiv. Kungl. vitterhets och antikvitets akademien.

Welinder, S. I985. Tunnackiga stenyxor och sambälle i Mellansverige 5000 B.P. Oslo: Universitetets Oldsaksamling.

Åberg, N. I9 I2. Studier öfver den yngre stenåldern i Norden och Västeuropa. Uppsala: Akademiska bokhandeln. 


\section{IMAGINARY VESSELS IN THE LATE BRONZE AGE OF GOTLAND AND SOUTH SCANDINAVIA:}

\section{Ship settings, rock carvings and decorated metalwork}

Richard Bradley, Peter Skoglund \& Joakim Wehlin

\begin{abstract}
The paper compares the Bronze Age ship settings of Gotland with the vessels portrayed in rock carvings on the Scandinavian mainland. It also makes comparisons with the drawings of vessels on decorated metalwork of the same period. It considers their interpretation in relation to two approaches taken to the depictions of ships in other media. One concerns the use of boats to transport the sun, while the other emphasises the close relationship between seagoing vessels and the dead. A third possibility concerns the distinctive organisation of prehistoric communities on Gotland. It seems possible that the largest of the ship settings were equivalent to the Bronze Age cult houses found on the mainland and that they may even have represented the island itself.
\end{abstract}

Key words: Bronze Age, ships, Gotland, rock carvings, metalwork, sun, death, house urns

\section{MOVING BETWEEN MEDIA}

The ship is one of the dominant features in the visual culture of the Bronze Age, but is represented in different media in different parts of Scandinavia. Towards the south, boats are depicted on bronze razors, whose distribution focuses mainly on Denmark (Kaul I998). Further 
to the north, they are an important component of prehistoric rock carvings and are particularly common in the south and west of Sweden and Norway (Malmer I98 I; Coles 2005; Goldhahn 2006). A third element is represented by stone ship settings. Although they occur on the mainland of Scandinavia, there is a marked concentration on Gotland (Fig. I) (Strömberg I96I; Müller-Wille I970; Capelle I986, I995; Artelius I996; Skoglund 2005, 2008; Widholm 2007).

The decorated metalwork is often found in burials (Dotzler I984; Kaul I 998), but the rock carvings depicting ships are usually associated

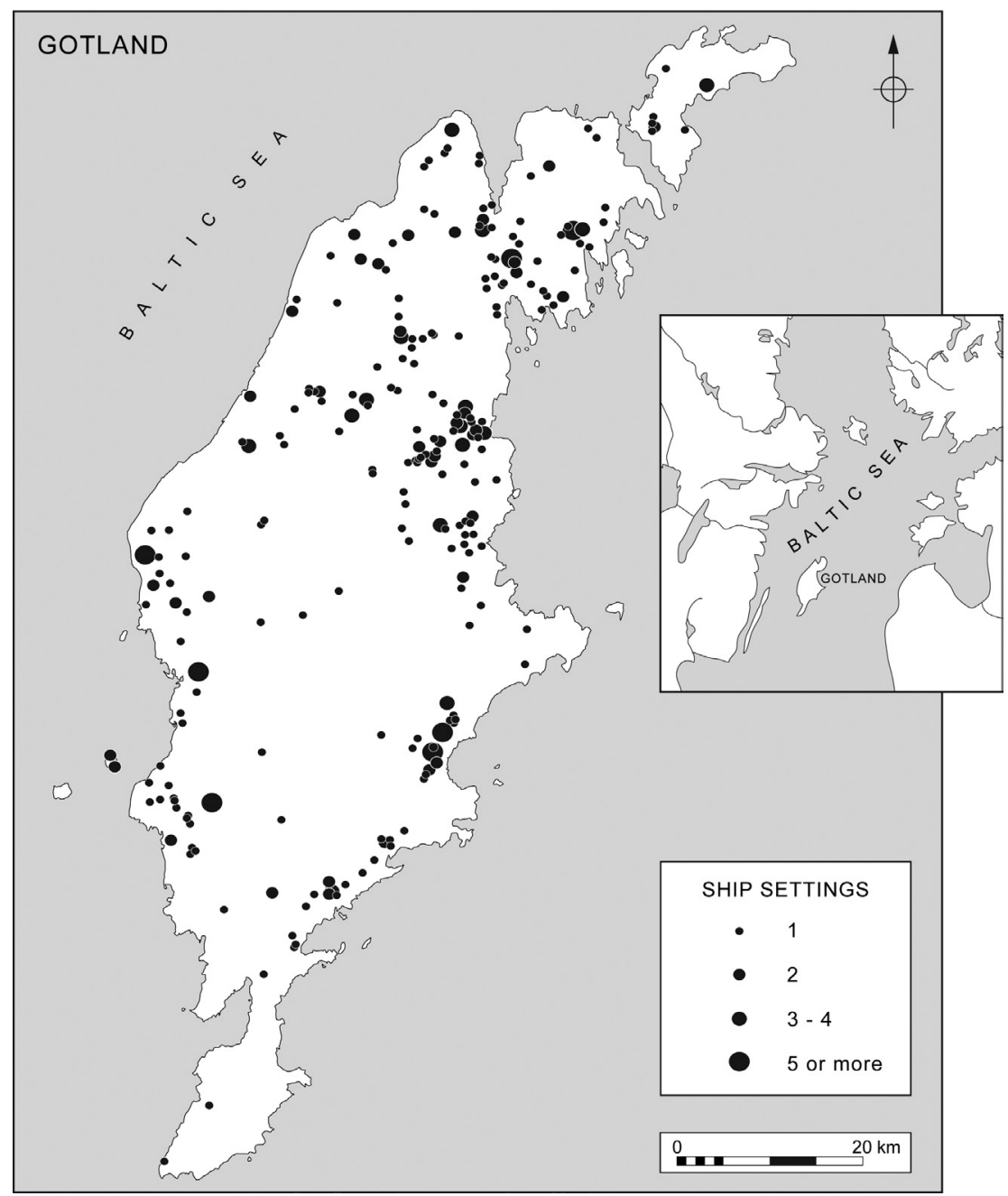

Figure I. The distribution of stone ship settings on Gotland.

Drawing: Aaron Watson after Joakim Wehlin. 
with water (Bradley 2006; Ling 2008). Many are near the sea, while other images are more frequent in landlocked areas. Ship settings are also located close to the coast (Hansson I927). It is particularly striking that they should occur in such large numbers on Gotland, for the island is in the Baltic Sea but accessible by boat from the Swedish mainland and from regions further to the south and east. The images on the decorated metalwork are commonly compared with those in Bronze Age rock art (Kaul I998; Ballard et al. 2003; Kristiansen \& Larsson 2005; Bradley 2006, 2008, 2009:chapters 6-8; Skoglund 2009), but ship settings of the same date are less often discussed, perhaps because they have such a restricted distribution. As a result, researchers have overlooked some striking connections between these distinctive media.

Many of the images were contemporary with one another. Although a few Early Bronze Age artefacts feature drawings of boats, most decorated metalwork dates from the Late Bronze Age (Kaul I998). Rock art was equally long-lived, but some of the most complex panels are attributed to the Late Bronze Age or even the Early Iron Age (Ling 2008). This is also the date of the ship settings on Gotland, a number of which have been excavated (Gustafson, I 878, I 89 I; Ulfsparre I 878; Hansson I927; Arwidsson I952; Silvén I954; Manneke I967; Gerdin I974, I975, I979a, I979b; Grimlund-Manneke I979; Englund I979; Pettersson I982; Zerpe I998; Hallin 2002, 2003, 2004; Carlsson \& Widerström 2005).

It is worth comparing these features with one another, but that is only possible by considering the evidence from South Scandinavia as a whole. Otherwise there is too much regional variation. For example, in Gotland boats are represented on just two of the decorated rocks (Burenhult I973, I980; Broström I999). By contrast, the island contains three hundred stone ships and there may have been many more (Stenberger 1945; Pettersson 1982; Hallin 2002). Similar distinctions can be recognised in other areas. There are occasional ship settings on the eastern shore of the Baltic, but they are well beyond the distribution of rock art (Grewingk I 878; Balodis I940; Nerman 1954; Graudonis I967; Capelle 1986, I995; Artelius I996; Pydyn I999). On the Swedish mainland, carvings of boats are normally found in different places from these monuments, and both are recorded in areas with few finds of decorated metalwork (Bradley \& Widholm 2007a). There is a similar contrast between the distributions of rock art and stone ships on the Danish island of Bornholm (Kaul et al. 2005:fig. I30). 

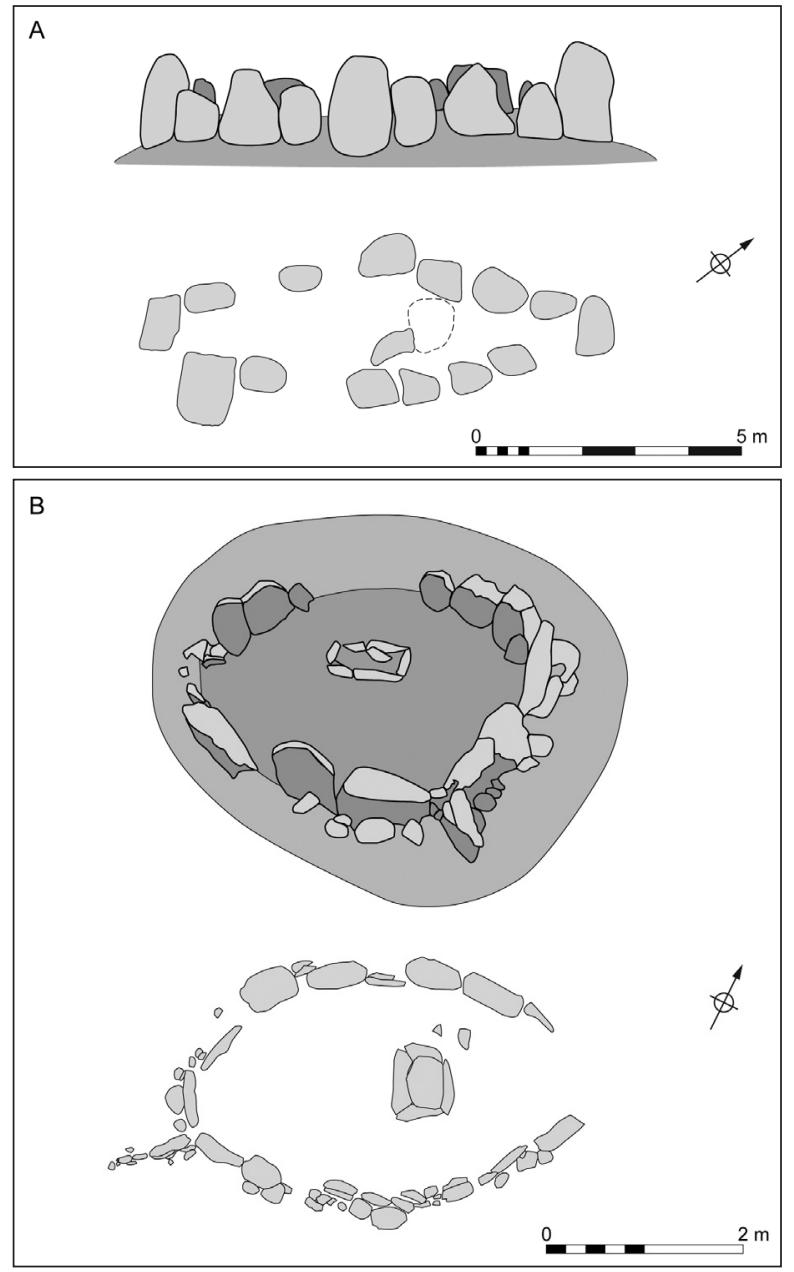

Figure 2. Plans and threedimensional drawings of smaller ship settings on Gotland.

Drawing: Aaron Watson after Joakim Wehlin (above from Hansson I927:84 and below from Pettersson I982:62).

The first part of this paper is concerned with formal comparisons between ship settings, rock carvings and artefacts with drawings of boats. The second part discusses their meanings for the people who made them.

\section{THEMES WITH VARIATIONS}

The Late Bronze Age ship settings of Gotland have a number of features which distinguish them from their counterparts elsewhere in Scandinavia (Figs. 2, 3).

Several characteristics are of fundamental importance. The ship settings on Gotland may be defined by a perimeter of standing stones, or 

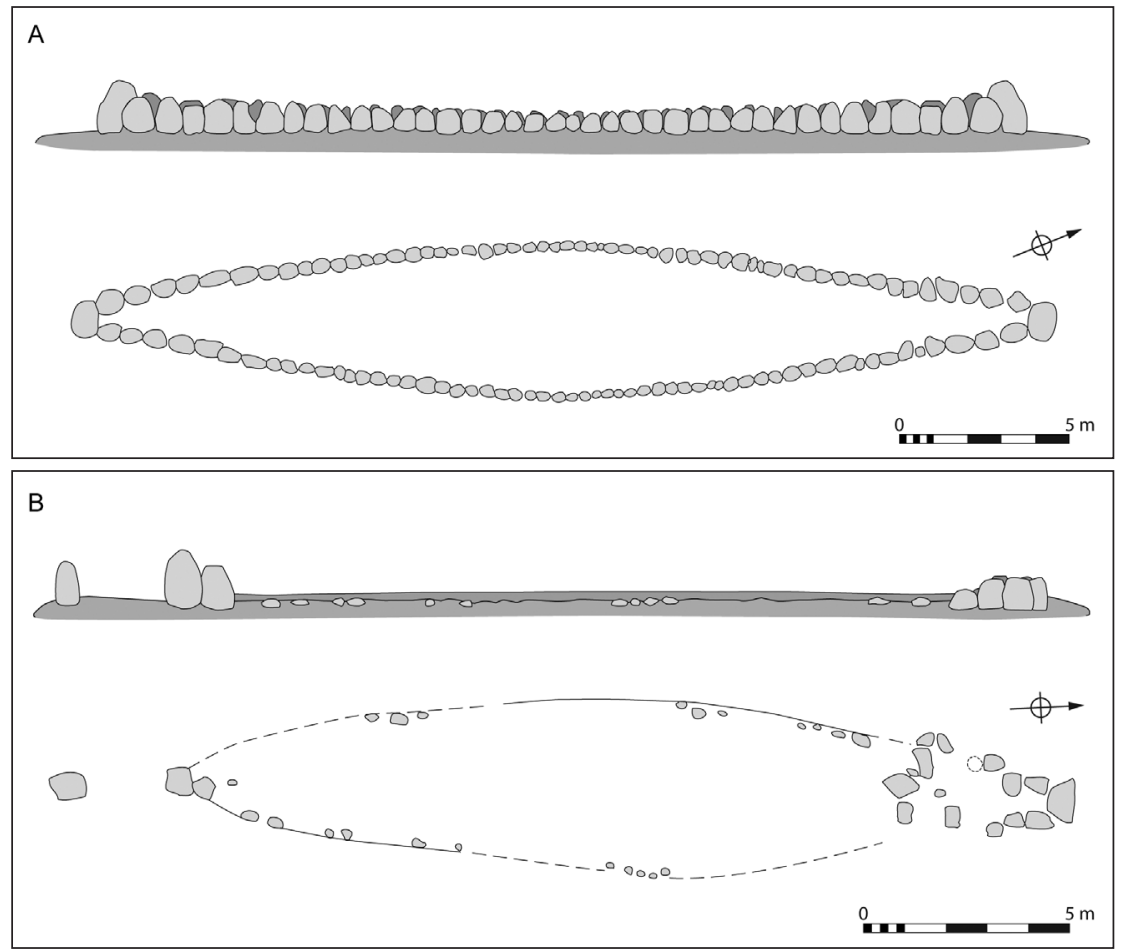

Figure 3. Plans and three-dimensional drawings of larger ship settings on Gotland.

Drawing: Aaron Watson after Joakim Wehlin and Peter Skoglund (above Nylén och Manneke I96I and below Lau RAÄ 4I:I).

they can be defined by a boulder kerb. The kerbs often mark the limits of low cairns, but other monuments take the form of a largely empty enclosure. At some of the sites with kerbs only the ends of the vessel were marked by upright stones. Their sizes vary, too. The smallest monuments are less than ten metres long, but the lengths of the most prominent examples approach forty metres. Many of the vessels were laid out in two sections, separated by taller stones placed half way along either side. The ship settings on the mainland occur in a similar range of sizes to those found on the island. Again they include inconspicuous cairns defined by kerbs. In both areas these structures are associated with Late Bronze Age cremations, accompanied by bronze artefacts such as razors, tweezers and pins (Artelius I996). The sites on Gotland can also include house urns. Nine of the thirteen examples from the island were discovered in ship settings. They are not found with similar monuments in other regions (Arwidsson 1952; Grimlund-Manneke I979; Pettersson I982; Sabatini 2007). 
Where ship settings on Gotland are defined by standing stones, the uprights occur at intervals of approximately a metre and are usually paired across the long axis of the vessel. Some attempt was made to select stones of similar appearance. The tallest examples define the middle of the ship setting and the positions of the prow and stern. At most sites the monoliths are rounded boulders which had been shaped by glacial action or perhaps collected from the seashore. There is little to suggest that they had been modified before they were used. Colour may also have been important because red stones seem to have been employed in the central part of the vessels and towards either end. The remainder of the monument is usually white or grey.

Other details may be equally significant. The end stones can be pointed, as if to suggest a boat with a raised prow and stern. That is particularly obvious where the rest of the monument is bounded by an inconspicuous kerb. Occasionally one end of the structure features a distinctive rectangular compartment. This is extremely small, and on a real ship it could have accommodated only one person, presumably the helmsman. The square end of the vessel was evidently the stern, whilst the pointed end would have marked the position of the bow. Both ends could also be indicated by detached monoliths continuing the axis of the boat, although this is very uncommon.

The ship settings on Gotland can appear singly or, more often, in small groups. Most follow the axis of the nearest coast, but in many cases the structures are symmetrical and it does not seem to have been important to distinguish between the prow and the stern. Ship settings are often found with other structures, normally round cairns or smaller stone monuments. They were constructed in a distinctive manner and were often defined by long, roughly rectangular kerbstones which are quite different from the taller monoliths associated with the most conspicuous ship settings. The chronology of the circular monuments is by no means clear, and in Gotland the ship settings can follow a path leading in between other monuments.

A number of these features recall the characteristics of rock carvings and decorated metalwork where images of ships play a prominent part.

\section{Ship settings and rock carvings (Fig. 4)}

The first comparison is with the rock art of the South Scandinavian Bronze Age. Several features are especially important: the forms taken by the boats; the presence or absence of a crew; the numbers of people 

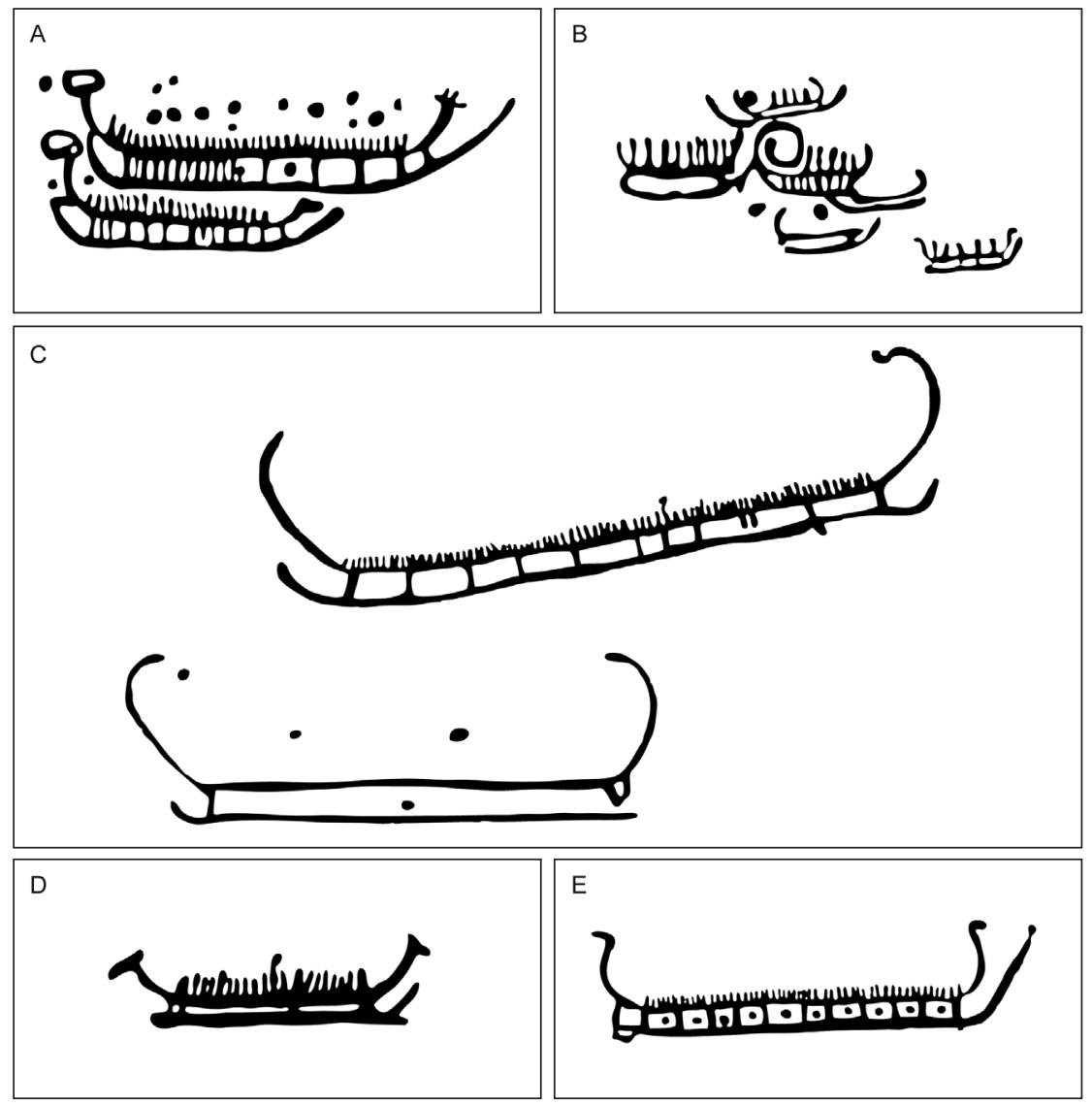

Figure 4. Details of rock carvings on the mainland of south-east Sweden. A: Boats with larger crews; B: Boats with smaller crews; C: Pairing of an empty boat and a vessel with its crew; D: Ship with a raised central figure; E: Ship with a large crew and subdivisions of the hull.

Drawing: Aaron Watson after Burenhult (I973).

on board; the direction of travel; and the distinctive siting of both ship settings and rock carvings.

All the ships in Scandinavian rock art are depicted in side view, so that the drawings show the elevation of the vessel and indicate the position of its crew (Glob 1969; Burenhult 1973; Malmer 1981). Although the forms of the ships changed over time, a consistent feature is the raised prow and stern. In the petroglyphs the prow may be embellished with a horse's head. This helps to establish the direction in which the boat is travelling (Strömberg I983). Another indication is a line extending from the stern, continuing the axis of the keel. In most cases the crew is depicted by a series of vertical strokes, and it is com- 
monly supposed that each represents a pair of individuals. There is no evidence of a sail, and paddles are rarely shown. The latest vessels are a little different, for they have a symmetrical profile. In this case it is impossible to tell the prow from the stern unless a rudder or steering oar is represented. This kind of vessel has been compared with the Hjortspring boat from Denmark and is dated to the Early Iron Age (Crumlin-Pedersen \& Trakadas 2003).

The ship settings on Gotland share some of the same features. In almost every case the prow and stern are indicated by the tallest stones, whilst the others may increase in height towards the ends of the vessel. There are occasional contrasts between the shapes of the monoliths in these positions, but it is not always clear whether this results from modern reconstruction. Occasionally keel extensions may be indicated by a line of upright stones continuing the long axis of the vessel. Where the edge of the structure was marked by monoliths rather than a boulder kerb, the stones were usually arranged in pairs across the body of the vessel. Seen from the side, they resemble the 'crew strokes' in Bronze Age rock art. The links between these pairs are sometimes emphasised by the shapes or sizes of the uprights. At the same time each monolith has a distinctive appearance and can be separated from its neighbour by a small gap in the perimeter of the monument; it seems likely that they were meant to represent not only the ship itself but also specific individuals. If the stones represented a crew, this would explain their individual character as well as the pairing of uprights on either side of the vessel.

The idea that standing stones could represent people is common in ethnography. For example, standing stones at sacred places in the Marquesas and Tikopia islands are believed to represent people (or gods) (Handy 1927:I7I; Firth I970:I20f). The idea is also known from Gotlandic folklore, where several larger stones, or groups of stones, are believed to be people and animals who were transformed on their way to or from the church.

Finally, the presence of two taller monoliths at the midpoint of the vessel may even have its counterpart in the rock art of south-east Sweden where a taller and/or wider crew stroke is occasionally depicted in the equivalent position. On the other hand, the ship settings are more symmetrical than the majority of the vessels illustrated by rock carvings.

These observations apply to those ship settings with a continuous perimeter of standing stones. Others lack this feature and are defined 
by less conspicuous kerbstones, in which case only the ends of the vessel are indicated by monoliths. At these monuments there is no indication of a crew, and the boat could even be empty. There are sites on Gotland where ship settings of both kinds are juxtaposed. The best known example is at Gnisvärd. A similar contrast is present in Bronze Age rock art, although it is seldom discussed. Johan Ling suggests that $23 \%$ of the Late Bronze Age vessels in his study area in Bohuslän are shown without a crew (Ling 2008:194). The same applies to the smaller sample dating from the Iron Age when the proportion of empty vessels rises to $32 \%$. In Småland and Blekinge - the parts of the Swedish mainland nearest to the island - empty vessels account for approximately $28 \%$ of the drawings of ships, but in this case it is more difficult to establish the dates of some of the individual vessels (Bradley 2008). Sometimes empty boats are paired with others carrying a crew. That pattern is found on many sites, but is particularly apparent on the principal outcrop at Himmelstalund, virtually opposite the northern tip of Gotland (Hauptman Wahlgren 2002). It is difficult to provide comparable figures for the ship settings on the island as some monuments have been restored and others remain unexcavated. It is enough to say that ships with crews and 'empty' vessels are widely distributed and that they are sometimes juxtaposed.

More can be said about the sizes of the crews represented in these media. Again Johan Ling provides some useful statistics on the number of people represented in the rock art of Bohuslän. He has recorded the number of 'crew strokes' in a large sample of Late Bronze Age drawings of ships. The range is usually between six and twelve, and the most common number is seven. Since the ships are viewed from the side, each crew stroke should represent a pair of individuals seated opposite one another, indicating that the sizes of the boat crews were usually between twelve and twenty four and that the norm was approximately fourteen (Ling 2008:fig. IO.II).

A smaller sample of rock carvings on the south-east coast of Sweden provides similar results. Here most of the ships are associated with between six and twelve crew strokes. In this case the commonest number was nine, suggesting that the boats were manned by eighteen people (Bradley 2008). It is difficult to provide exact figures for the number of monoliths associated with the ship settings on Gotland, but they are usually between twelve and twenty; fourteen and sixteen appear to be the commonest numbers, and this suggests the sizes of the crews. 
It would apply to most structures of this kind, which are up to ten metres in length. On the other hand, there are a few ship settings in Gotland that can be four times as long. They are considered in a separate section of this paper.

In South Scandinavian rock art it seems to have been important to show the direction in which the vessels were travelling (Bradley 2006 , 2009:chapter 7). That is less apparent with the ship settings of Gotland. Where they were built with upright stones the direction of sailing is rarely indicated. They may have been thought of as travelling in two directions - the closest comparison is with the latest boats depicted in rock art. On the other hand, it is possible to distinguish between the bow and the stern in some of the stone vessels with a low kerb.

The two media have one more feature in common, as ship settings and carvings of ships are frequently located near to water and often close to the shoreline. It has long been suggested that drawings of boats are most common near the sea and that other kinds of images were favoured in landlocked areas. That is not quite true, as carvings of ships on the Scandinavian mainland are also associated with rivers and inland lakes. In any case the relationship breaks down towards the northern limit of this style of rock art (Sognnes 200I). Further to the south, however, the close relationship between depictions of ships and the coast has become still more apparent with Johan Ling's work in the west of Sweden. It not only suggests that petroglyphs were nearer to the sea than had been supposed before, it even raises the possibility that they were most frequent in places which were accessible by boat (Ling 2008:222ff). The same argument might apply to the ship settings, but less is known about the shoreline of Gotland, which certainly changed during the course of the Bronze Age and Early Iron Age.

\section{Ship settings and decorated metalwork (Fig. 5)}

Can similar comparisons be made with the images on Bronze Age metalwork? In this case there are fewer topics to consider: the forms of the vessels are important, and so are the sizes of their crews.

Like the rock carvings, the drawings of ships on bronze artefacts show vessels with a raised prow and stern (Kaul I998). They normally depict keel extensions, and a series of upright lines is thought to represent the crew. Again the boats are seen from the side. Many of them are accompanied by other images, including animals, fish, and what are probably representations of the sun. Some of these designs are nat- 

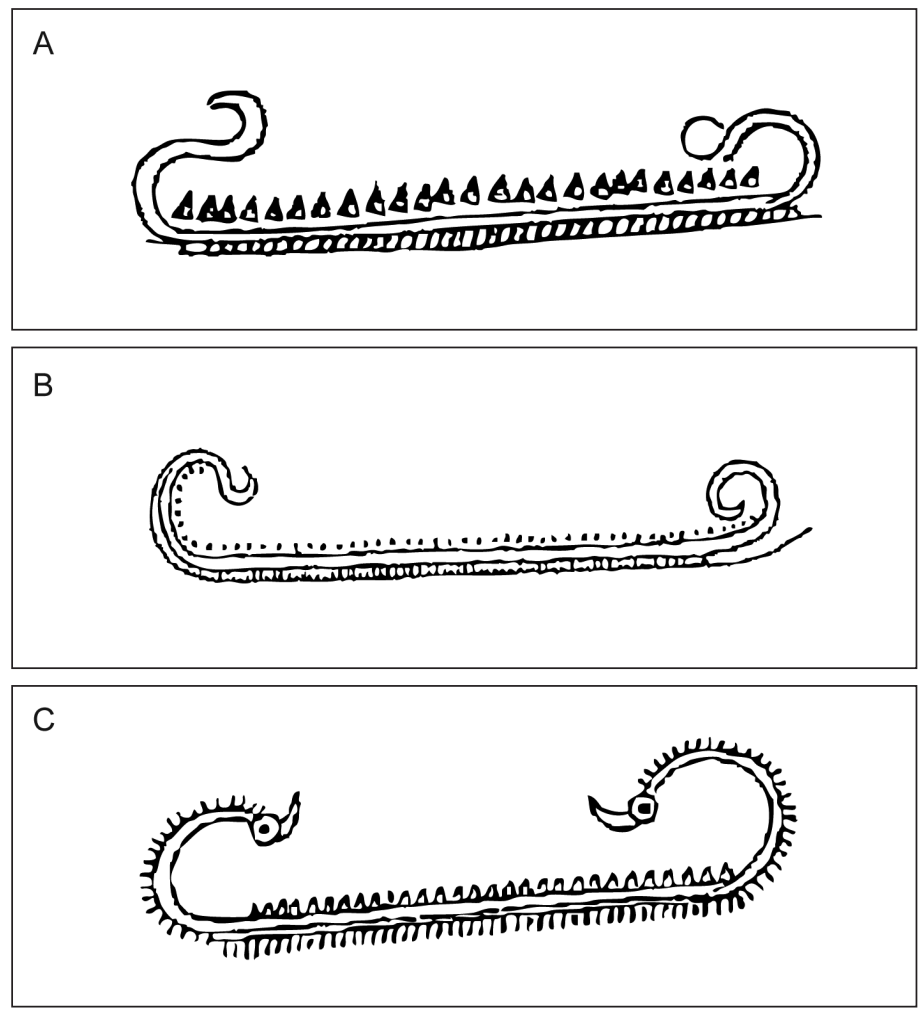

Figure 5. Three drawings of ships and their crews depicted on bronze razors. Drawing: Aaron Watson after Kaul (I998).

uralistic but many are extremely stylised. Flemming Kaul has shown that the direction of travel is an important feature of the metalwork (I998:chapter II). The vessels sailing from left to right are often associated with a horse, and those moving in the opposite direction can be accompanied by a fish or a snake. He relates these designs to the passage of the sun across the sky during the day, and its movement beneath the sea at night (Kaul I998, 2004). The vessels themselves are similar to those depicted in South Scandinavian rock art, but in other respects the images created in these different media diverge from one another. The drawings on the metalwork illustrate the relationship between the sea and the sky, whilst rock art also refers to activities on land (Bradley 2009:chapters 7 and 8).

By their very nature ship settings can only be associated with the sea. If the smaller examples show the same kinds of vessels as most of the rock carvings, how are those in Gotland related to the designs on metal 
artefacts? Again the basic shapes are very similar. The vessels are shown in elevation with a raised prow and stern. Even the keel extensions may be represented by short rows of stones continuing the axis of the vessel.

In other respects the images created in these two media differ from one another. The only association is between these monuments and circular cairns or platforms. It remains to be seen whether it happens very often, and at present there is little to suggest that the boats were entering or leaving these constructions in the way that happens on the mainland (Artelius I 996; Nordenborg Myhre 2004:chapter 6; Bradley \& Widholm 2007a and b). Indeed, it is not known whether these structures were contemporary with one another; monuments with radial divisions like a wheel cross may belong to a later period than the ship settings. Kaul's interpretation of the metalwork emphasises the drawings of the sun, but it also considers the directions in which the vessels are travelling. Again the ship settings have a quite different emphasis, and in many cases no attempt was made to illustrate this feature.

More information is provided by the drawings of crews on the decorated metalwork. Unfortunately, the only comprehensive catalogue is limited to Danish finds (Kaul I998), but the high quality of its illustrations makes it possible to estimate the number of people on board. There are usually between sixteen and thirty 'crew strokes', but in exceptional cases the figure can rise to sixty or more. Again each vertical line should represent two individuals, suggesting that in most cases these boats were carrying between thirty and sixty people (Bradley 2008). A few rock carvings on the mainland show boats of similar sizes, but these are altogether exceptional. In Ling's study area at Tanum only I $2 \%$ of the drawings show ships with more than fifteen crew strokes. In a smaller sample from the south-east shoreline of the Baltic the equivalent figure is $24 \%$ (Ling 2008:fig. IO.I I; Bradley 2008).

The remains of wooden boats of later date suggest that there is a consistent relationship between the length of the vessel and the number of people it can carry. This assumes that it was paddled by a crew arranged in pairs. Each person would occupy approximately a metre of the hull, but the members of the crew would also be spaced a metre apart in order to have room for manoeuvre (Randsborg I995:chapter I; Clark 2004:chapter ıo; Crumlin-Pedersen \& Trakadas, 2003). On that basis it should be possible to work out the sizes of the vessels represented on the metalwork. It suggests that their prototypes were between fifteen and thirty metres in length, with exceptional examples 
which were even longer. The larger ship settings on Gotland fall within that range. They include 'empty' vessels as well as open enclosures defined by monoliths, the largest of which is forty-five metres long. Such monuments are very different from the smaller structures discussed earlier. If the majority of the stone ships can be compared with the vessels illustrated in Bronze Age rock art, these exceptional constructions refer to the kinds of ship which are drawn on artefacts of the same period.

\section{SUMMARY}

The ship settings of Gotland have certain features with a wider distribution in Scandinavia. The first is the distinction between stone ships which are shown with crews represented by upright stones, and boats that were apparently empty. Both types can be found on the same sites on Gotland, just as those with crews are paired with empty vessels in the rock art of the mainland.

A second distinction concerns the sizes of the boats and the representations of a crew. Most of the ship settings on Gotland depict small vessels with crews of under twenty. Sometimes they show considerably fewer people. The same applies to most of the rock carvings in South Scandinavia which feature ships with a similar number of individuals on board.

By contrast, the great majority of the decorated bronzes illustrate much larger craft, manned by significantly more individuals. The boats represented on the metalwork are rarely found with fewer than fifteen crew strokes, and in most cases the figure is much higher. If these vessels had any equivalents among the stone ship settings, they must be the comparatively rare examples which were up to forty metres long.

The significance of these patterns is considered in the final section of this paper.

\section{DISCUSSION}

One way of assessing the significance of the Gotlandic ship settings is to compare their interpretation with those of Bronze Age images on the mainland. Three topics are considered here: ships and the passage of the sun; ships and mortuary rites; and travel and island identities.

\section{Ships and the sun}

Kaul has argued that the images on Late Bronze Age metalwork illustrate a narrative in which ships carry the sun through the sky during the day and under the water at night (Kaul I998, 2004). There are in- 
dications of similar elements in South Scandinavian rock art (e.g. Ohlmarks I 963; Hauptman Wahlgren 2002; Kristiansen \& Larsson 2005), although other themes are also illustrated in this medium (Bradley 2009:I 50-I 68). To what extent can Kaul's interpretation be extended to the ship settings of Gotland?

He emphasises the link between seagoing vessels and sun symbols. There are certainly sites on Gotland where stone ships and circular settings are found together, but this does not seem to happen in every case, and at present there is little to show whether these structures were contemporary with one another. That may not negate Kaul's hypothesis in relation to the ship settings, but, unlike the pairs of carved footprints recorded on the mainland (Bradley 2009:I95ff), the ship settings do not conform to any obvious solar alignment. In fact they are moving both north and south, and different vessels on the same sites can travel in opposite directions.

In Kaul's model the sun crosses the sky from left to right between dawn and dusk. It returns beneath the sea, moving from right to left during the hours of darkness. Perhaps the inhabitants of Gotland took a different view. Because it is an island, out of sight of the mainland, the sun appears to rise from the water to the east. It travels across the sky until it reaches its highest point beyond the southern end of the island. Eventually it sets into the sea to the west. Thus the sun moves around much of the coast during the course of the day. Is it possible that the ship settings that follow the shoreline reflect its daily journey? The idea is tempting, for, like the boats on the decorated metalwork, many of the stone ships travel in two directions. This is an interpretation which requires more research.

\section{Ships and the dead}

Another possibility can be considered. There is evidence that on the mainland images of ships were directly associated with the dead (e.g. Randsborg 1993; Goldhahn I999). Metalwork with drawings of boats was commonly deposited in graves (Dotzler I984; Kaul 1998), and rock carvings depicting ships are often associated with cairns (Ling 2008). In fact these images are even found inside cists (Jellestad Syvertsen 2002). There are rock carvings which suggest that vessels are travelling between such monuments and the water's edge (Wrigglesworth 2002), and there may even be a connection between depictions of empty vessels and the commemoration of the dead (Bradley 2006). Thus the 
decorated cist at Kivik contrasts one vessel sailing into the chamber with its crew and an empty boat towards the back of the same structure (Randsborg I 993:27-34). The 'day ships' depicted on the kerb of the barrow at Sagaholm are depicted with people on board, whilst the 'night ships' which travel around the monument in the opposite direction are apparently empty (Goldhahn 1999). The decorated outcrop at Hjortekrog may have a similar significance. Here all but one of the ship carvings buried beneath a Late Bronze Age cairn are shown without their crews (Widholm I999).

At same time the boundary between land and water possessed a special importance. It is where carved rocks are commonly found, and large cairns attributed to the Early Bronze Age follow the shorelines of the Baltic and the North Atlantic where they frequently overlook the sea. Equally impressive funerary monuments were built on small islands off the coast. This is particularly revealing since it is unlikely that those places were inhabited at the time. In that case the dead must have been taken there by boat (Bradley \& Widholm 2007a).

Another distinctive feature of the eastern mainland of Sweden is the pairing of stone ship settings with small rectangular monuments whose proportions (but not their sizes) are similar to those of Late Bronze Age domestic buildings. It seems possible that they were intended to represent the sea and the land respectively. Their appearance together would have emphasised the special importance of the shoreline. Both are found with round cairns at cemeteries like Hjortekrog and Snäckedal, where it seems as if some of the boats were travelling in and out of those monuments (Bradley \& Widholm 2007a and b; Bradley 2009: I66ff).

That is very different from the situation on Gotland. Here large Early Bronze Age cairns were built close to the sea, but in this case there is less evidence for the use of small offshore islands. Late Bronze Age stone ships have a comparable distribution and effectively ring the coast (Hansson 1927; Stenberger I945; Hallin 2002). Like carvings of boats on the mainland, they are usually near the water's edge. Some of the excavated ship settings are associated with human cremations and even with bronze razors in the form of a boat (Hansson I927; Gerdin I974, I975, I979a, I979b; Grimlund-Manneke I979; Pettersson I982). The burials are also inside house urns. Although ceramics of this kind are widely distributed in Northern Europe, these are the only examples to be discovered in ship settings (Arwidsson 1952; Grimlund-Manneke 
I979; Pettersson I982; Sabatini 2007). The point is particularly striking since stone settings in the form of a house are entirely absent on the island. The contrast with the eastern coast of Sweden could hardly be more evident, yet in both areas the seashore may have been associated with the boundary between the living and the dead.

It is commonly assumed that ships were treated as a symbol of the voyage of the dead to the otherworld (Artelius I996), and this interpretation seems entirely reasonable. On the other hand, it does not explain the contrast between vessels with crews and empty boats which happens with both ship settings and rock carvings. Perhaps the petroglyphs can shed light on this distinction, for at a number of sites ships seem to cross the decorated panel as if they are travelling away from the viewer. As this happens, the crew disappears from view. Boats with a full complement on board are replaced by empty vessels as they recede into the distance. That observation could be interpreted in many ways, but one possibility is that this device represents the transformation of the dead (Bradley 2006, 2009:chapter 7 and I 85 f). How is the idea relevant to Gotland? Perhaps the ship settings represented two distinct conceptions of the dead, or two stages in the rites of passage: the first when specific people were commemorated, and the second when they had been transformed into an undifferentiated body of ancestors (Skoglund 20I0).

If this notion is correct, different kinds of ship settings would have separate ritual and social meanings. They will be explored in the final part of the paper.

\section{Travel and island identities}

A basic assumption made in this article is that the vessels defined by upright stones indicate ships with crews. These stones are often paired; they are regularly spaced and are separated by small gaps from one another. It makes them stand out as individuals. This arrangement is not found in the monuments on the mainland and emphasises the special connection between ships and people on Gotland; a phenomenon with parallels in island communities in other parts of the world (Ballard et al. 2003).

From this perspective the ship settings may provide some evidence of social organisation, for it seems as if they were commonly divided into two equal segments, suggesting some kind of social division onboard the boat itself. It may be no accident that in some cases that 
basic module was repeated several times in the same group of monuments. Occasionally, the pattern is still more complex. Thus at Rannarve (Klinte parish) four vessels with this characteristic were built end to end (Grimlund-Manneke I979), and at Domarlunden (Lärbro parish) another five stone ships were constructed side by side (Hansson 1927; Gerdin I974, I975, I979b). It may be no coincidence that, taken together, their lengths -34 metres and 35 metres respectively - are very similar to one another and also to those of the largest ship settings on the island.

There is a little evidence for a similar arrangement in the rock art of the south-east Baltic, but it has not been discussed. As mentioned earlier, in a few instances the carvings of ship are divided in half by an unusually high or broad vertical line. This has the effect of separating the people on board into two groups, but there are cases where the practice seems to have gone even further. The crew strokes are separated into several groups, each of approximately the same size. Occasionally, the distinctions between them are reflected by subdivisions of the hull. This pattern is by no means common and is never found on decorated metalwork. It suggests that some of the larger vessels were associated with several communities.

The stone boats of the Scandinavian Bronze Age have been discussed by Rausing (I984) and Capelle (I995), both of whom distinguish between smaller craft used for travel over short distances and larger 'warships' which were suited to longer voyages. Their analyses are based on two criteria: the proportions of the stone ships found on the mainland of South Scandinavia, and the overall lengths of these monuments. In their interpretations the smaller vessels have length: width ratios of between 2.5:I and 4: I and may be up to sixteen metres in length. The 'warships' are significantly longer and narrower. In this case the same ratio is between 6:I and 8:I. The difference between these vessels is clearly reflected in the rock art of the Swedish mainland (Bradley 2008). Applying the method described earlier, a vessel sixteen metres long would be depicted with eight crew strokes; among the carved images the commonest figure is seven. The smaller vessels would be well suited to calm water. Ships with much larger crews - perhaps thirty or more - should belong in the other category (see also Ellmers I995).

These distinctions may be helpful since Gotland is an island. The smaller boats were probably used for short journeys along the coast, and only the larger vessels are likely to have travelled to the mainland. 
Almost $50 \%$ of the ship settings are between 8 and I 3 metres long. This can be compared to the size of traditional Gotlandic wooden fishing boats (Liljeros 200I:7ff). Only Io \% of the monuments are over 20 metres in length. Another comparison may be helpful here. Christopher Tilley discusses the significance of different types of canoes in the Vanuatu archipelago. Here the simplest forms could be seen in their hundreds, but only a few vessels of the most complex type were made, and these were intended for use at extraordinary events. For example, there were two types of canoe on the island of Malekula. The smaller canoes were for travel along the coast; they are still used today. Another larger type was used in the past for exchange and ceremonial expeditions (Tilley I999: I06, I I 8f).

Johan Ling's research in Bohuslän has points in common with this interpretation. The rock carvings were made in places that were readily accessible by sea. Smaller craft are commonly found in places that would have been half a day's journey apart, but those at Tanum stand out because they include a greater proportion of 'warships' (Ling 2008:chapter IO). Similar studies have yet to be undertaken along the east coast of Sweden, but it seems as if a similar distinction might be made, with drawings of the larger vessels at sites along the shoreline or major rivers at places like Boglösa (Coles 2000:78-97) and Himmelstalund (Hauptman Wahlgren 2002). They would have provided important landfalls for voyagers travelling long distances.

There are indications of the same geographical pattern in two other media (Fig. 6). Some of the biggest ship settings on the mainland, like those at Hellerö (Hedengran \& Janzon I999; Sigvallius 2005), Snäckedal (Widholm I998, 2007) and Lofta (Hansson I936), were readily accessible from Gotland (Bradley \& Widholm 2007a). There are indications that further sites along the coast were equally important. There are a number of places where unusually large cairns are found together with the distinctive structures known as 'cult houses' (Victor 2002). The best known examples of this relationship are at Kivik and Hågahögen. Again these monuments were accessible from the sea.

The largest ship settings on Gotland occupy similar positions, but cult houses are entirely absent. This may be significant, for some of the largest stone ships also formed open enclosures. It may be useful to compare these different monuments with one another. On the mainland, stone enclosures with the proportions of a domestic dwelling seem to have been constructed close to the water's edge. There is little evidence 


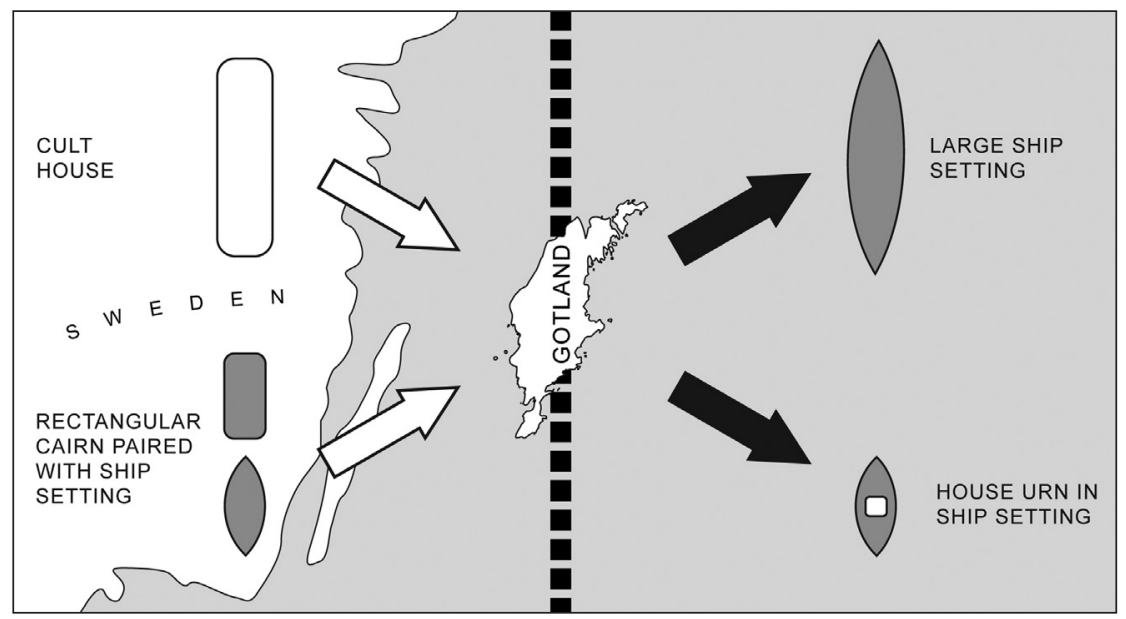

Figure 6. Contrasts between the representations of ships and houses on Gotland and the mainland of south-east Sweden.

Drawing: Aaron Watson.

that they were roofed, and it seems as if they played a specialised role in ceremonial (Victor 2002). The largest ship settings on Gotland may have had a similar significance, and again they might have been connected with the commemoration of the dead, for smaller monuments of the same type are associated with cremation burials. The contrast between cult houses and stone ships could be particularly revealing. On the mainland the buildings employed in rituals assumed the form of a house. On Gotland, however, they adopted the ship as their prototype, and yet both kinds of monument were constructed in similar locations. They could have been employed in a variety of public events, but the form of the ship setting evokes the importance of travel, whilst that of the cult house suggests the security of the domestic dwelling. Both emphasised the shoreline as the borderland between the living and the dead.

The smaller ship settings may have had a rather different significance, for they can be associated with cremation burials. They are also found with house urns (Hansson 1927; Arwidsson 1952; GrimlundManneke 1979; Pettersson 1982; Sabatini 2007). That association is revealing, for the use of those ceramics could have emphasised the importance of a group of people who belonged to the same community. They may even have been members of a single household, for the burials include men, women and children and do not seem to be those of specialised boat crews. Like the house urn itself, the small stone ves- 
sels provided a metaphor for a social group who could have lived and worked together. Such ship settings are widely distributed and share that feature in common with the largest monuments.

It may be possible to take the argument one stage further, although it is necessarily speculative. One of the most striking characteristics of the Late Bronze Age archaeology of Gotland is the practice of depositing house urns in a monument in the form of a boat (Sabatini 2007). It gives the impression of a domestic building superimposed on a ship (Fig. 6). That is completely different from the situation on the west coast of the Baltic where stone vessels and 'house cairns' were separate and were built side by side (Bradley \& Widholm 2007a and b). Were models of domestic buildings deposited on board the stone ships of Gotland because the boat represented an entire community, and were the largest ships meant to stand for the inhabitants of the whole island? There may be a good reason for taking this view. People who were accustomed to sailing around the island, taking their bearings from the land and from the sun, would have had a clear conception of its distinctive outline, even in the absence of a chart. Gotland is long and narrow and comes to a point at its northern and southern extremes. That is very similar to the outline of the large stone vessels. Is it possible that the greatest ship settings of all were meant to represent the island as a whole? Was Gotland itself imagined as an enormous vessel in the middle of the ocean?

\section{Conclusion}

There are many similarities between Gotlandic stone ship settings and the vessels represented in other media on the mainland. The position of the ships close to water, the number of people on board, the layout of the boats and the organisation of the crews are all reflected in other kinds of ships depicted on decorated rocks or metalwork elsewhere in Northern Europe. On a general level it is also possible to make associations between the Gotlandic stone ship settings and a cosmology concerned with the movement of the sun.

What makes the Gotlandic stone ships settings stand out in a comparative perspective is the connection between ships and people. Individuals were not only buried inside ships, they were also represented by the upright stones that made up the outline of the vessels. There seems to be an association between social units and these boats. The smaller ships were divided in two; different vessels were linked together; and, 
finally, there were extraordinarily large ships which could represent the integration of local groups into larger communities.

This association between people and seagoing vessels might explain why the Bronze Age stone ships of Gotland play such an exceptional role in Scandinavian archaeology.

Richard Bradley, Department of Archaeology, School of Human and Environmental Sciences, University, Whiteknights, Reading RG6 6AB, United Kingdom

Peter Skoglund, Sydsvensk Arkeologi AB, Box 406, 20I 24 Malmö, Sweden

Joakim Wehlin, Department of Historical Studies, University of Gothenburg, and Department of Archaeology, School of Culture, Energy and Environment,

Gotland University, Cramérgatan 3, 62I 67 Visby, Sweden

\section{Acknowledgement}

This paper is the outcome of a joint trip to Gotland undertaken by the authors in April 2009. The trip was partly financed by $D B W$, Visby and the University of Reading. The illustrations are by Aaron Watson. 


\section{References}

Artelius, T. 1996. Långfärd och Återkomst - skeppet i bronsålderns gravar. Kungsbacka: Riksantikvarieämbetet.

Arwidsson, G. 1952. Husurnan från Ansarve i Tofta, Gotländskt Arkiv. Pp. I6-37.

Ballard, C., Bradley, R., Nordenborg Myhre, L. \& Wilson, M. 2003. The ship as symbol in the prehistory of Scandinavia and South-east Asia. World Archaeology. Vol. 35. Pp. 385-403.

Balodis, F. 1940. Det äldsta Lettland. Uppsala.

Bradley, R. 2006. Danish razors and Swedish rocks. Cosmology and the Bronze Age landscape. Antiquity. Vol. 80. Pp. 372-378.

Bradley, R. 2008. Ship-settings and boat crews in the Bronze Age of Scandinavia. In: Goldhahn, J. (Ed.). Gropar och monument. En vänbok till Dag Widholm. Pp. I 7I-I 84 Kalmar: Kalmar University.

Bradley, R. 2009. Image and Audience. Rethinking Prehistoric Art. Oxford: Oxford University Press.

Bradley, R. \& Widholm, D. 2007a. Bronze Age cosmology in the south-west Baltic: a framework for research. In: Widholm, D. (Ed.). Stone Ships. The Sea and the Heavenly Journey. Pp. I3-48 Kalmar: Kalmar University.

Bradley, R. \& Widholm, D 2007b. The mountain of ships: the organisation of the Bronze Age cemetery at Snäckadal, Misterhult, Småland. In: Hårdh, B. Jennbert, K. \& Olausson, D. (Eds.). On the Road. Studies in Honour of Lars Larsson. Pp. 246-52. Stockholm: Almqvist \& Wiksell International.

Broström, S-G. I999. Hällristning på Fårö. Rapport över dokumentation av hällristning RAÄ nr 379 i Fårö s:n på Gotland. BOTARK.

Burenhult, G. 1973. The Rock Carvings of Götaland, Part 2. Lund.

Burenhult, G. I980. The Rock Carvings of Götaland, Part I. Stockholm.

Capelle, T. I986. Schiffsetzungen. Praehistorische Zeitschrift. Vol. 61. Pp. I-63.

Capelle, T. 1995. Bronze Age stone ships. In: Crumlin-Pedersen, O. \& Thye, B.M. (Eds.). The Ship as Symbol in Prehistoric and Medieval Scandinavia. Pp. 7 I-75. Copenhagen: National Museum.

Carlsson, D. \& Widerström, P. 2005. Arkeologisk slutundersökning Stora Vikers I:94, Lärbro socken, Gotlands län och kommun. ArkeoDok (www.arkeodok.com)

Clark, P. (Ed.). 2004. The Dover Bronze Age Boat. London: English Heritage.

Coles, J. 2000. Patterns in a Rocky Land. Rock Carvings in South-West Uppland, Sweden. Uppsala: Uppsala University.

Coles, J. M. 2005. Shadows of a northern past: Rock carvings of Bohuslän and Østfold. Oxford: Oxbow Books.

Crumlin-Pedersen, O. \& Trakadas, A. (Eds.). 2003. Hjortspring: a Pre-Roman IronAge warship in context. Roskilde: The Viking Ship Museum in Roskilde.

Dotzler, G. I984. Ornament als Zeichen: methodologische Probleme der archäologischen Interpretation. Frankfurt am Main: P. Lang.

Ellmers, D. 1995. Crew structure on board Scandinavian vessels. In: Olsen, O., Madsen, J. \& Rieck, F. (Eds.). Shipshape. Essays for Ole Crumlin-Pedersen: Pp. 23 I-40. Roskilde: The Viking Ship Museum in Roskilde.

Englund, S. 1979. Uppgarde i Vallstena, In: Falck, W. (Ed.). Arkeologi på Gotland. Pp. 53. Visby: Press.

Firth, R. 1970. Rank and Religion in Tikopia. London: George Allen and Unwin. 
Gerdin, A.-L. I974. Domarlunden i Lärbro. Gotländskt Arkiv. Pp. I I6.

Gerdin, A.-L. I975. "Domarlunden” i Lärbro. Gotländskt Arkiv. Pp. I I 2-I I 3.

Gerdin, A.-L. I979a. Sorby i Stenkyrka, In: Falck, W. (Ed.). Arkeologi på Gotland. Pp. 43-46. Visby: Press.

Gerdin, A.-L. 1979b. Domarlunden i Lärbro, In: Falck, W. (Eds.). Arkeologi på Gotland. Pp. 50-52. Visby: Press.

Glob, P.V. I969. Helleristninger i Danmark. Copenhagen.

Goldhahn, J. 1999. Sagaholm. Hällristningar och gravritual. Umeå: Umeå University.

Goldhahn, J. 2006. Hällbildsstudier i norra Europa: trender och tradition under det nya millenniet. Gothenburg: University of Gothenburg.

Graudonis, J. J. 1967. Latvija v epochu pozdnej bronzy i rannego železa: Načalo razloženija pervobytnoobščinnogo stroja. Riga.

Grewingk, C, I878. Die Steinschiffe von Musching und die Wella-Laiwa oder Teufelsböte Kurlands überhaupt. Dorpat.

Grimlund-Manneke, G. I979. Rannarve i Klinte In: Falck, W. (Ed.). Arkeologi på Gotland. Pp. 46-49. Visby: Press.

Gustafson, G. I 878. Berättelse om grafundersökningar, gjorda i Lärbro socken, Gotland sommaren 1877 . Kongl. Vitterhets Historie och Antiquitets Akademiens Månadsblad. Pp. 633-658.

Gustafson, G. I891. Grafundersökningar på Gotland. I-VI, Antiqvarisk tidsskrift för Sverige VII. Nr. 4. Pp. I-87.

Hallin, G. 2002. Kummel, skepp och koksten - en studie om bosättningsområden och social struktur under bronsåldern på Gotland. Dissertation, Department of Archaeology and Classical Studies. Stockholm: Stockholm University.

Hallin, G. 2003 . Undersökning av en skeppssättning i Liffride I:8, Alskog socken september 2003 -Delrapport I, Arkeologisk undersökning av fast fornlämning $\mathrm{nr} 62$ på fastigheten Liffride $\mathrm{I}: 8$, Alskog socken på Gotland.

Hallin, G. 2004. Undersökning av en skeppssättning i Liffride I:8, Alskog socken september 2004-Delrapport II, Arkeologisk undersökning av fast fornlämning $\mathrm{nr} 62$ på fastigheten Liffride $\mathrm{I}: 8$, Alskog socken på Gotland.

Handy, E. S. C. I927. Polynesian religion. Bernice P. Bishop Museum Bulletin 34. Honolulu.

Hansson, H. 1927. Gotlands Bronsålder. Stockholm: Kungliga Vitterhets-, historieoch antikvitetsakademien.

Hansson, H. 1936. Några nya bronsåldersgravar. Fornvännen. Vol.3 1. Pp. 327-343.

Hauptman Wahlgren, K. 2002. Bilder av betydelse. Hällristningar och bronsålderslanskap i nordöstra Östergötland. Lindome: Bricoleur Press.

Hedengran, I. \& Janzon, G. O. I999. De stenbundna skeppen: om skeppsristningar och skeppsformade stensättningar i Tjust, nordöstra Småland. In: Gustafsson, A. \& Karlsson, H. (Eds.). Glyfer och arkeologiska rum. Pp. 375-400. Gothenburg: University of Gothenburg.

Jellestad Syvertsen, K. 2002. Ristninger i graver - graver med ristninger. In: Goldhahn, J. (Ed.). Bilder av Bronsålder: Pp. I 5 I-83. Stockholm: Almqvist \& Wiksell International.

Kaul, F. 1998. Ships on Bronzes. A Study in Bronze Age Religion and Iconography. Copenhagen: National Museum.

Kaul, F. 2004. Bronzealderens religion: studier af den nordiske bronsealders ikonografi. Copenhagen: Det Kongelige Nordiske Oldskriftselskab. 
Kaul, F., Stoltze, M., Nielsen, F. O. \& Milstreu, G. 2005. Helleristninger. Billeder fra Bornholms bronzealder. Rønne: Bornholms museum.

Kristiansen, K. \& Larsson, T. B. 2005. The rise of Bronze Age society: travels, transmissions and transformations. Cambridge: Cambridge University Press.

Liljeros, B. 200г. Gotländska båtar. Uddevalla: Föreningen Allmogebåtar.

Ling, J. 2008. Elevated Rock Art. Towards a Maritime Understanding of Rock Art in Northern Bohuslän, Sweden. Gothenburg: University of Gothenburg.

Malmer, M. I98 I. A Chorological Study of North European Rock Art. Stockholm: Kungliga Vitterhets-, historie- och antikvitetsakademien.

Manneke, P. I967. Restaureringen av skeppssättningen vid Gannarve i Fröjel. Gotländskt Arkiv. Pp. 43-52.

Müller-Wille, M. I970. Bestattung im Boot: Studien zu einer nordeuropäischen Grabsitte. Neumünster: Wachholtz.

Nerman, B. I954. Yngre bronsåldern - En första svensk vikingatid. Fornvännen. Vol. 49. Pp. 257-285.

Nordenborg Myhre, L. 2004. Trialectic Archaeology. Monuments and Space in Southwest Norway. Stavanger: Arkeologisk museum.

Nylén, E. \& Manneke, P. I96I. Gotland, Fröjel sn. Gannarve. Rapport rörande restaurering av skeppssättning, Unpublished report ATA 4724/6I.

Ohlmarks, A. I963. Hällristningarnas gudar: en sammanställning och ett förklaringsförsök. Stockholm: Tiden.

Pettersson, A-M. I982. Skeppssättningar $i$ Rute, En undersökning av sex gravar från den yngre bronsåldern, RAGU:s skriftserie I 982:2. Visby: Riksantikvarieämbetets Gotlandsundersökningar.

Pydyn, A. I999. Exchange and cultural interactions: a study of long-distance trade and cross-cultural contacts in the Late Bronze Age and Early Iron Age in central and eastern Europe. Oxford: Archaeopress.

Randsborg, K. I993. Kivik. Archaeology and ideology. Acta Archaeologica. Vol. 64(I). Pp I-I 47.

Randsborg, K. I995. Hjortspring. Warfare and Sacrifice in Early Europe Århus: Aarhus University Press.

Rausing, G. I984. Prehistoric boats and ships of northwestern Europe: some reflections. Malmö: LiberFörlag/Gleerup.

Sabatini, S. 2007. House urns: study of a late Bronze Age trans-cultural phenomenon. Dissertation, Department of Archaeology. Gothenburg: University of Gothenburg.

Sigvallius, B. 2005. Sailing towards the Afterlife. Analysis of a ship-formed burial monument at Hellerö by the Baltic Sea, In: Artelius, T. \& Svanberg, F. (Eds.). Dealing with the dead: archaeological perspectives on prehistoric Scandinavian burial ritual. Pp. I 59-I7I. Stockholm: Riksantikvarieämbetet.

Silvén, U. I954. Bronsåldersboplats och skeppssättningar vid St. Bjers Stenkyrka sn. Gotländskt Arkiv. Pp. I3-3 I.

Skoglund, P. 2005. Ideal och praktik - skeppssättningar i yngre bronsåldern. In: Goldhahn, J. (Ed.). Mellan sten och järn 2. Pp. 343-352. Gothenburg: University of Gothenburg.

Skoglund, P. 2008. Stone ships: continuity and change in Scandinavian prehistory. World Archaeology. Vol. 40(3). Pp 390-406.

Skoglund, P. 2009. Beyond chiefs and networks. Corporate strategies in Bronze Age Scandinavia. Journal of Social Archaeology. Vol. 9(2). Pp. 200-2 I9. 
Skoglund, P. 20I0. Cosmology and Performance. Narrative Perspectives on Scandinavian Rock-art. In: Goldhan, J., Fuglestvedt, I. \& Jones, A. (Eds.). Changing pictures: Rock Art Traditions and Visions in the Northernmost Europe. Oxford: Oxbow.

Sognnes, K. 200 I. Prehistoric Imagery and Landscape: Rock Art in Stjordal, Trondelag, Norway. Oxford: British Archaeological Reports.

Stenberger, M. 1945. Det forntida Gotland.

Strömberg, H. I983. Båttyper på hällristningar i Kville: ett inlägg i diskussionen om hällristningsbåtarnas konstruktion. Uddevalla: Bohusläns museum.

Strömberg, M. I96r. Die Bronzezeitlichen Schiffssetzungen im Norden. Meddelanden frä Lunds universitets historiska museum. Pp. 82-106.

Tilley, C. 1999. Metaphor and material culture. Oxford: Blackwell Publishers.

Ulfsparre, S. I 878. Iakttagelser under resor åren I870-I876 jemte några anteckningar om en samling af fornsaker. Stockholm.

Victor, H. 2002. Med graven som granne. Om bronsålderns kulthus Uppsala: Uppsala University.

Widholm, D. I998. Rösen, ristningar och riter. Lund: Almqvist \& Wiksell International.

Widholm, D. I999. Rock art as part of Bronze Age funerary rites. In: Goldhahn, J. (Ed.). Rock Art as Social Representation. Pp. 65-75 Oxford: Archaeopress.

Widholm, D. (Ed.). 2007. Stone ships: the sea and the heavenly journey. Kalmar: Kalmar University.

Zerpe, L. I998. Undersökning av en skeppssättning i Gräne - ett samarbete mellan Väte hembygdsförening och Gotlands fornsal. Gotländskt Arkiv. Pp. 7-ı6.

Wrigglesworth, M. 2002. Ristninger og graver i landskapet. In: Goldhahn, J. (Ed.). Bilder av Bronsålder: I 85-I99. Stockholm: Almqvist \& Wiksell International. 



\section{THE DIVINE APPEARANCE OF HÄRN}

\section{Determining the identity of a Bronze Age metal hoard}

Magdalena Forsgren
This article aims to investigate the mysterious divinity Härn on the basis of a Bronze Age metal hoard from Härnevi in Uppland. The premise is that this hoard represents a cultural category that reflects a divine concept that must be investigated in order to understand the meaning behind the deposition. Through mythological parallels, Härn's characteristics will be explored as well as the relation between the sun and fertility across time and space. It is suggested that Härn originally was a sun goddess emanating from the Bronze Age and related to the Norse goddesses Njärd and Freyja.

Key words: Härnevi, metal hoard, Bronze Age, comparative mythology, folklore, sun, fertility

\section{INTRODUCTION}

How is it possible to obtain knowledge about the characteristics of an unknown divinity such as Härn who only occurs in a few Swedish place names? The name Härnevi had attracted interest for a long time (Grau I 754; Ekblom I 872), but it was not until Hans Hildebrand (I 899:6) drew attention to the sacral meaning of the second part of the place name that discussions started as to which divinity "Härn referred to; compound place names with -vi are usually theophoric. Magnus Olsen suggested in 1908 that Härn was related to one of Freyja's second names, Hørn, mentioned in Snorre's Edda. Nevertheless, it was Hans Sperber's (I9I2) suggestion that Härn is derived from an old word for 
flax which drew the greatest support. He claimed that Härn was an old demon of vegetation that subsequently merged with Freyja. Although this proposal was criticized at an early stage (Lindroth I9I 5 ), the relation between Härn and Freyja has been advocated by archaeologists, historians of religion and some onomasticians (e.g. Olsen I 9 I 5; de Vries I93 5:I 25; Hellberg I986; Näsström I 995:85; Lindeberg I997; Kraft I999; Bäck et al. 2008:8). Lars Elmevik (I995) has, however, criticized this and instead suggested that the first element of Härnevi is derived from "cerin with the meaning ársguð 'god of year's crop' which refers to Freyr. This suggestion has in turn been rejected by Per Vikstrand (200I:208) who instead claims that when tracing the origin of Härnevi it is better to assume a name with an initial $h$. His conclusion is that, although Härn probably can be understood as the name of a deity, the gender cannot be determined by linguistic means.

This article aims to determine who Härn is by using a Bronze Age metal hoard from Härnevi parish in Uppland as a point of departure, and thereby also grasp the identity of this hoard. The Härnevi hoard, containing various broken artefacts from different periods and deposited sometime before $500 \mathrm{BC}$, was discovered during ditch-digging for drainage in an arable field in I902. Originally, the idea was that Härn is one means by which to understand the deposition, but it just as likely may be the opposite. In accordance with my earlier research, the premise of this article is that the Härnevi hoard represents a cultural category that reflects a divine concept that must be investigated in order to fully understand the reasons for this deposition (Forsgren 2007,2008 ). If one understands this hoard, one may also understand the divinity Härn: what was Härn's gender, what symbols were related to this divinity, and what were its characteristics? In the following I will briefly present my current understanding of the Härnevi hoard, and then compare this understanding with mythological parallels. This work will serve as a contribution on understanding hoards as different concepts and identities as well as Bronze Age mythology.

\section{SANCTUARY OF PEACE AND PROSPERITY}

The Härnevi hoard has previously received attention in place-name discussions but most often been rejected on the assumption that metal hoards with broken artefacts should be understood in terms of scrapmetal hoards and therefore of little interest to mythological discussions (Forsgren 2008 with references; see Lundberg I9I2; Sperber I9I2; 
Vikstrand 200I:308f). An essential part of Vikstrand's discussion is therewith to point out the difficulties in determining the age of the name Härnevi due to the strong archaeological traditions back to the Bronze Age. In addition to the hoard, Härnevi parish is well known for the remains of bronze casting at a nearby settlement, and there are also several mounds of fire-cracked stones in this area (Forsgren 2007, 2008).

There are two main reasons why it is of interest to discuss the hoard and the place name together. Firstly, if one considers the place of deposition, the artefacts were discovered right in front of a triangular, inward bend in a flat, moraine plateau. The place resembles a natural, smallscale amphitheatre where it is easy to picture actors performing ritual plays (Forsgren 2008:I0). With one exception (Sahlgren I952:86), scholars have agreed that the last element of Härnevi means 'holy place' or 'sanctuary', a place which possessed a religious right of asylum and associated with peace and prosperity (Vikstrand 200I:298f, $324 \mathrm{f}$ with references). Although there are discussions on how the cult places referred to in place names were physically formed and organized in the landscape, there is a general assumption that cult places were of varying nature and often originated in the Iron Age (e.g. Vikstrand 200I; Sundqvist 2007:I43ff). It has to be stressed that no sanctuary deriving from the Iron Age has been discovered in Härnevi while at the same time it is possible to comprehend the amphitheatre as the ritual centre of a consecrated area, framed by a number of cairns at the outer edges of Härnevi (Forsgren 2008).

The second reason for discussing the hoard together with the place name is that the hoard contains many artefacts which can be considered to have had ritual functions associated with the sun, such as the hanging bowl, the domed belt ornament, and the pins with disc-shaped heads. The decorative ornaments, including double buttons, spiralinclined bracelets, a hair-spiral and one spectacle-shaped brooch, to a large extent set the standard of this hoard. Many of those artefacts can be associated with women, but the spearhead and probably also the socketed axe are normally associated with men, which makes this hoard a complex combination of artefacts and difficult to interpret. Why do weapons occur in a collection of female jewellery? Apart from ornaments and weapons, the hoard also includes serrated sickles, small pieces of leather with a button, fragments of daggers and a cauldron, and casting residue. Why are there so many different types of artefacts collected in a single hoard? (Forsgren 2007 with references). 


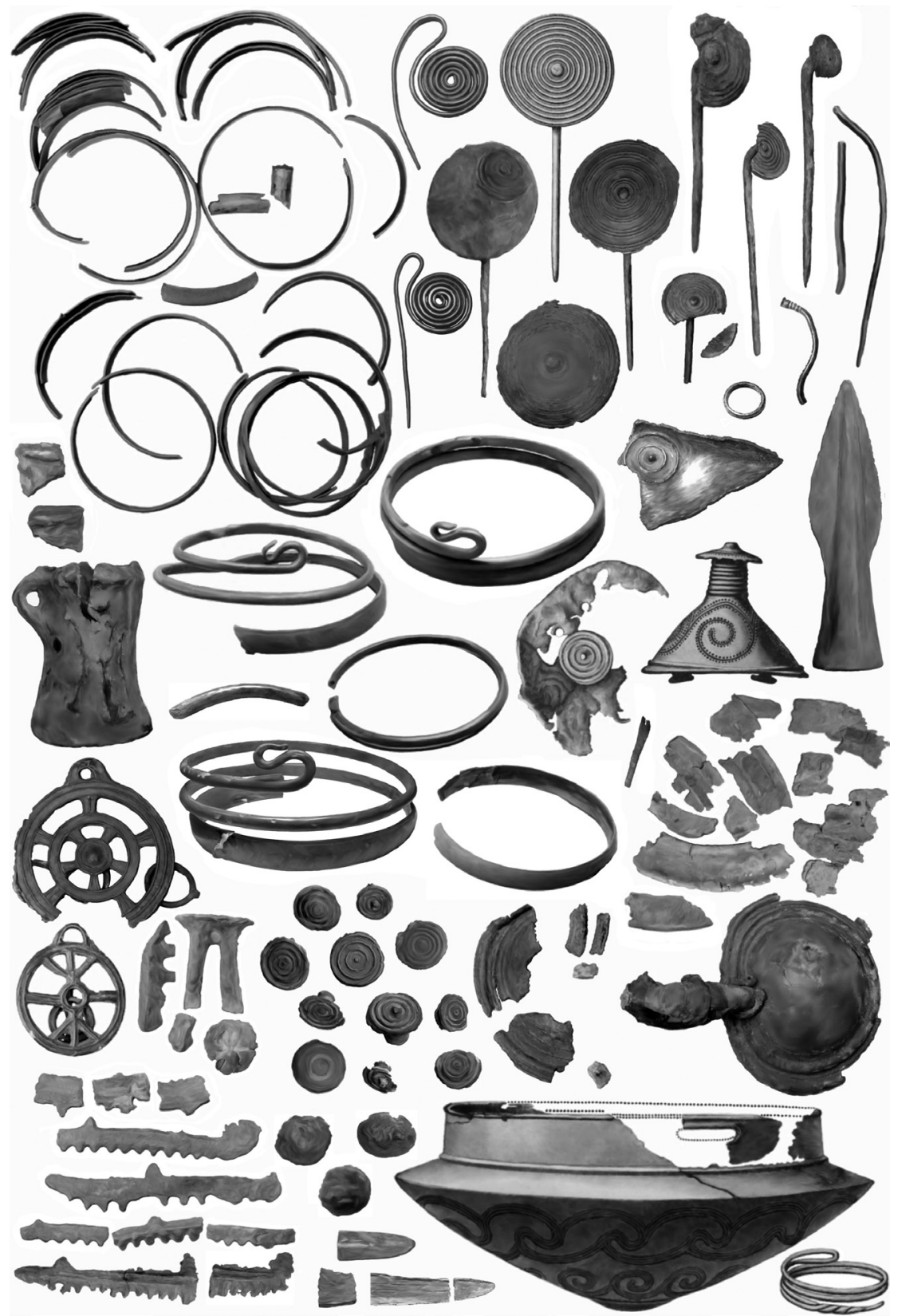

Fig. I. Collage of the Härnevi hoard. Among the female ornaments are also some tools and weapons.

Drawings by the author after Ekholm I92I and photos from the Museum of National Antiquities. 


\section{IN FAVOUR OF THE SUN}

The two wheel-like artefacts with clattering pendants are unique and have only one known parallel. The Eskelhem hoard contains, besides bridle fittings for horses and a hanging bowl, one large jingle-plate or sun-wheel which has resulted in an interpretation of this hoard as the remains of a ritual ride (Montelius I 887). Montelius recalled what Tacitus tells about the Germanic fertility goddess Nerthus: on an island in the ocean is a sacred grove where a wagon stands, used for transporting the image of the goddess through the surroundings at pax et quies 'times when all fights rested and general peace reigned'. With this as inspiration, Lundberg suggested that the artefacts in the Härnevi hoard were used when celebrating the wedding of the goddess of fertility (Lundberg I9I 2:36f; Tacitus I999 ch. 40). However, one important question arises concerning the relation between the sun and fertility.

For a long period of time researchers have agreed that Bronze Age society used the sun as a key element (e.g. Helander 1906; la Cour I924; Brøndsted 1938). However, so far not many researchers have been interested in the relation between the goddess of fertility and the sun. Yet if fertility was also of great importance during the Bronze Age, this relation ought to be further investigated. The sun seems an important element in Bronze Age religious perception, as exemplified by the famous Trundholm chariot from Denmark - a bronze wheeled model of a horse pulling a large disc with one side covered by a thin layer of gold. The chariot is also a good example of the close symbolic connection between the sun and horses during this time. Based on an analysis of mainly Late Bronze Age razors, Flemming Kaul (I998) has suggested that people in Scandinavia apprehended cosmological myths where the sun is drawn across the sky in a ship (sometimes a chariot) with the help of different animals such as horses and snakes. Snake symbolism is recurrent also in the Härnevi hoard in the form of spiral-inclined bracelets with s-shaped terminals. The terminals are similar to many handles of razors which always take the shape of animal heads. Likewise, the decoration of the bracelets from Härnevi is remindful of the pattern on a viper (Forsgren 2007:I 5 f; $c f$. Sperber's I9I 2 suggestion that bracelets can be understood as "snakes in the hands of the giantess" and used as symbolic reins).

Kaul (I998:55f) writes that "since the sun seems to have been the staple element in Bronze Age religious perception, the possibility should not be excluded entirely that the sun in one way or another can have 
developed into a personified divinity proper". If one understands how the sun was perceived in prehistoric times, one may also understand who Härn was, the combination of artefacts in the hoard, and the relation between the sun and fertility.

\section{CIRCLING THE EARTH}

What we seek is a deity associated with the sun which has horse and snake attributes and which travels across the sky in a ship or chariot. In order to continue, comparative studies must be conducted in an attempt to identify shared themes and characteristics and thereby supplement what is already known. I want to stress the importance of assuring an analytical connection in time and space when making analogies; one could therefore either compare with later Norse mythology or with Bronze Age mythologies from other areas. The first strategy gives a possible insight into pre-Christian world perception in Scandinavia, which I consider valuable to begin with because it is possible to imagine fluid traditions back to the Bronze Age. Thereby I imply that historical sources convey meanings which in certain cases may be relevant also in Bronze Age studies (Andrén 2004a).

In Norse mythology there is one solar deity to be found, namely the goddess Sól, meaning 'sun'. She and her brother Máni 'moon' were placed in the sky where Sól had to take the reins of two horses, Árvakr 'early awake' and Álsviðr 'very quick' (Grimnismál verse 37), which pull Sól's chariot Álfröðull 'elf-disc' across the sky; in Alvíssmál I 7 it is told that the elves called Sól 'the lovely wheel'. The term Álfröðull is ambiguous and not only refers to the sun-chariot but also to the sun herself. In Vafprúðnismál 23 it is told that Álfröðull will give birth to a beautiful daughter before she is eaten by the wolf Fenrir at Ragnarökr, and that this daughter will continue to ride along her mother's path (The Poetic Edda I 999). Not much else is known about Sól, perhaps because the Norse pantheon includes so many other important deities that Sól seems uninteresting in comparison. She seems, however, to have a later counterpart in Baltic mythology.

The current knowledge of Baltic, i.e. Latvian and Lithuanian, mythology is limited to a diverse and sometimes contradictory folklore material from the last centuries. Notes have nevertheless been made in earlier times in chronicles about the Balts' deification of the celestial powers, which indicate the deep traditions of the folklore material (Puhvel 1974; Biezais 1975, I987; Kokare 1996). It is worth noting 
that a sun cult seems to have existed in the Baltic countries during the Bronze Age. This is shown by the material culture which in part reflects the Scandinavian material, such as cup-marked stones, pins with discshaped heads of Härnevi-type and double buttons, which indicate cultural exchanges during this time period (e.g. Tvauri I999; Lang 2007; Luik \& Ots 2007).

\section{A NEW DAY WILL ALWAYS ARISE}

Among the gods in Baltic mythology, Saule (Lith. Saule Latv.) is a central figure. She is called màte which not only means 'mother' but also 'goddess'; Saule is thus 'the mother goddess of the sun'. Saule travels over the sky mountain from the east at dawn to the west at dusk in a chariot drawn by two white horses with golden manes. On her journey, Saule brings with her the deceased and in the evening the passengers change to a boat and travel beneath the earth. In the realm of the dead, Saule leaves the deceased so she once again can reach the east at dawn and start her journey all over again. Here a connection can be observed between chariot and boat on the one hand, and sky and water on the other. The universe can moreover be divided into two levels, heaven and earth, a division which is expressed in the word pasaule 'under the sun', meaning 'earth' (Biezais I975:33 If, I987; $c f$. Mandt I986). Of course, this is remindful of the cosmological myths illustrated by Scandinavian Bronze Age artefacts where the sun is drawn across the sky with the help of horses and snakes.

Snakes were also important in Baltic mythology, but the Balts' relation to them seems somewhat ambivalent. Occasionally snakes were enemies of Saule because they stole energy from her, and therefore they urgently had to be killed so that Saule would not start crying from fatigue. At the same time, snakes were regarded as important symbols of cyclic renewal and bearers of cosmic energy; by functioning as metaphors of the dying and reawakening nature, they shared life-giving properties of Mother Earth. Snakes also had strong sexual value and were perceived as important symbols of fertility. It was believed that snakes were able to resurrect after death and also to revive others. Thus, snakes were important in the worship of ancestors and accordingly it was regarded a sin to kill them. In some instances, Saule seems to have been friendly with snakes since they had so much in common. Possibly, although it is difficult to determine, the enmity between Saule and snakes evolved through Christian influence (Luven 200I). 


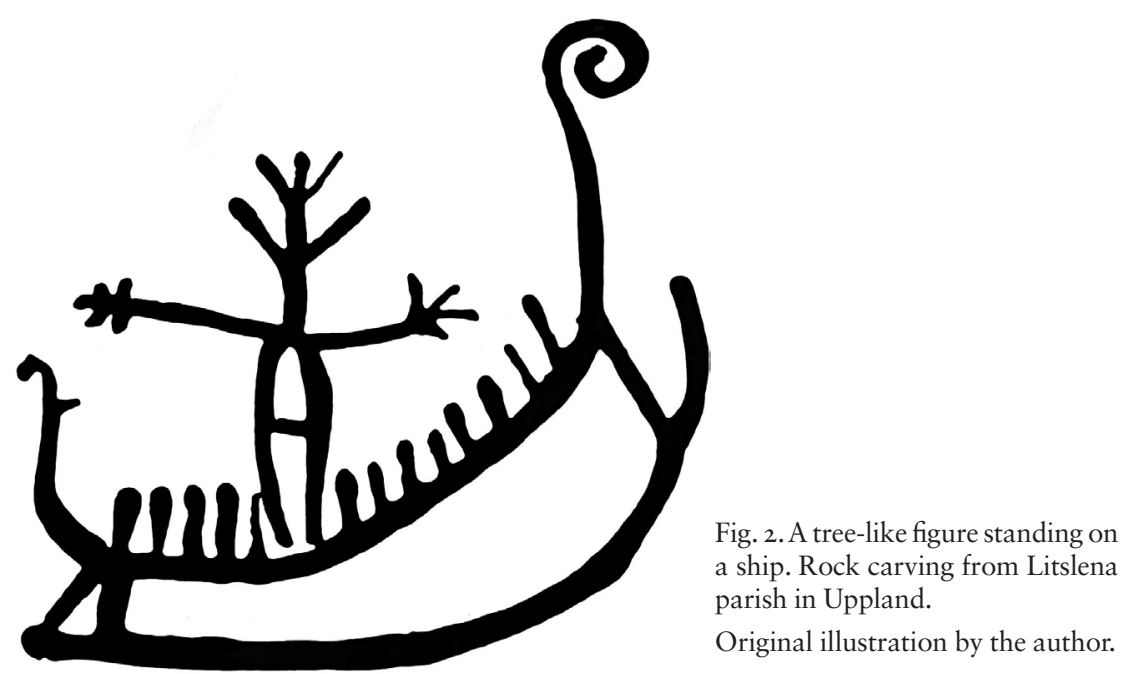

From a Scandinavian perspective, further information about Saule is of interest. Where the sun sets there grows a tree called saules koks 'the tree of the sun'. This tree was considered to be the centre of the world and the tree of life, which may go back to an old tradition where Saule was the source of life. The World Tree played an important role in Norse tradition as well, and it has been suggested that the idea of Yggdrasil as the centre of the world goes back to the Bronze Age (Andrén 2004 b). Not far from Härnevi there is a rock carving that includes a ship with a tree-like figure, which underlines this symbolism in this area during the Bronze Age. The concept of the World Tree also includes ideas about fertility. Despite Saule being a sun goddess, one of her most important roles was as goddess of growth and fertility, and the outcome of her walk across the field was a bountiful harvest (Biezais I975, I987; cf. Mandt 1986).

In order to create a structural mythological background to Saule and in extension also to Bronze Age mythology and Härnevi, some other gods in Baltic mythology should be mentioned. As in Norse mythology, the sun has a daughter which was the morning star Aušrinè (Lith; Saule Meita 'the daughter of the sun' Latv.). Even though the unreliable moon and warfare god Menulis (Lith; Mēness Latv.) was sometimes depicted as the divorced husband of Saule after the affair with Aušrine, Menulis was just as often depicted as Aušrine’'s husband. The father of Aušrinė was most probably the thunder god Perkūnas (Lith; Pērkons Latv.) which suggests that Saule and Perkūnas were once mar- 
ried. Saule sometimes also seems to have had a relationship with the god of heaven Dievas (Lith; Dievs Latv.) which is no wonder since the images of him and Perkūnas sometimes merged. The closest parallel was the Greek thunder god Zeus 'daylight' Keraunos (a paraphrase of Peraunos meaning 'thunder'; Biezais I975, I976, I987; Robbins Dexter 1984:138, 1990:40).

\section{THE ETERNAL FLAME}

One problem with the Baltic mythology is the gap in time to the Scandinavian Bronze Age. One must strive to find similar structures in Bronze Age mythologies to supplement what is known from Baltic mythology, and thereby assure the possibilities of such perceptions in regard to Bronze Age Härnevi. Such a search might provide clues as to how the occurrence of weapons in the Härnevi hoard should be understood, as well as the relation between the sun and fertility, since this is not possible by using the more recent Baltic parallel alone.

In a transcontinental perspective, there are few sun goddesses that are comparable to the Härnevi hoard and Saule. The Sun Goddess of Arinna, the highest patroness of the Hittite empire and ruler of justice, is one. To study an Anatolian goddess not only means that we move across a large geographical distance, but also that we are faced with a jumble of coalescing ancient cultures with heterogeneous and diverse pantheons. The Hittite realm corresponds in time to the earlier Bronze Age in Scandinavia (c. I800-1 I00 BC), and besides the Hittites it consisted mainly of the Luwians and Palawians. In addition, the early Hittites borrowed to a large extent their culture from the past Hattians (Haas I994a:Iff; cf. Bryce 2002:I34ff) which unlike the other peoples did not have a Proto-Indo-European background (Anthony 2007).

The importance of the Sun Goddess of Arinna can be traced back to the early time of the Hittite empire, but her origin seems much older since her predecessors probably were the Hattian sun goddesses Estan and Urunzimu 'mother earth'. For this role, chthonic properties were included as the sun travelled in the underworld during the night. Those properties were also manifested in one of the autumn festivals where the central theme was the harvesting and offering of fruits, wine and honey by the queen to the sun goddess. She was also understood as a goddess of fertility and moreover was invoked in connection with battle and with metal crafts (Haas I 994a:I90, 278, 42 Iff, 585 , cf. I $27 f f$, I 3 Iff; Bryce 2002:I 42). Here it is possible to see similarities to Härnevi; 
the hoard connects to fertility through the sickles, and at the nearby settlement traces of metal crafts have been found.

The Sun Goddess from Arinna was in her astral aspect primarily presented as a winged, golden sun-disc which also was a symbol of the Hittite kingdom, while her daughter Mezzulla was portrayed as a silver disc (Bryce 2002:I45; Haas I994a:204, 424, 426ff, 5 Iof). Possibly there was also a diffuse relationship to horses through the goddess Pirinkir, since she was also depicted as a sun-disc (Kristiansen $\&$ Larsson 2005:288; $c f$. Haas I 994a:4 I 5 f, I 994b). This of course is reminiscent of Sól's chariot Álfröðull, but it also brings to mind the two jingleplates in the Härnevi hoard.

Finally, it should be mentioned that the Hattian sun goddess Estan underwent a sex change when she was interconnected with the Hittite god Sius-summis 'our god' and became the sun god Ištanu. Sius then became a general word for 'god' in Hettite but was in origin an Indo-European word meaning 'to shine', etymologically related to the Latin deus 'god' and the Greek god of heavenly light Zeus Keraunos, the equivalent of Dievas Perkunas. The Hittite weather god Tarhun, a mythical relative to Zeus Keraunos, was portrayed as the spouse of the Sun Goddess of Arinna (Gurney I977:8ff, Iof; Haas I994a:I4I, I89, I92f, 377ff, 429; Bryce 2002:I 43f; $c f$. West 2007).

\section{THE PAN-EUROPEAN STRUCTURE}

Clearly, there are many commonalities between the Härnevi hoard and the Baltic mythology on the one hand, and the Hittite mythology on the other. At the same time, the Hittite mythology is inextricable and therefore caution is preferable before exporting the Hittite package and applying it to the Scandinavian Bronze Age. Yet it is assumed that "the sun/weather-god of heaven" Tarhun and the Sun Goddess of Arinna had counterparts in Scandinavian Bronze Age mythology that constituted separate aspects of the sun, as indicated by the day- and the night-side discs on the Trundholm chariot. This symbolism, it is argued, is consistent with several graves from the Early Bronze Age in Scandinavia in which a select group of women were buried with sundiscs of bronze (i.e. belt-plates attached to their bellies), remindful of the night-side of the chariot. Meanwhile, "a very small group of male chiefs" (Kristiansen \& Larsson 2005:294ff, 298), i.e. one, were buried with a gold disc: the day-side. Without going into details, I argue that this is not enough evidence to suggest that Scandinavian Bronze 
Age mythology included both a sun and weather god of heaven, and a night sun goddess.

In an overview of Indo-European religions and languages, it is noted that the sun was broadly viewed as masculine. This does not apply to northern Europe where a zone with different sun goddesses appears, perhaps influenced by substrate populations (West 2007:I95f). The sun was regarded as female in Sámi mythology as well, and perceived as a life-giving mother. A sun girl and a thunder god can also be noted (Mebius 2003:75ff), which is comparable to Baltic mythology. Axel Olrik (1905) assuredly believed that several elements of the Sámi mythology suggested influences from the Scandinavian Bronze Age. He assumed, however, that the sun was masculine in the latter, and consequently the Sámi sun must have later undergone a sex change and become female. For reasons of Swedish sovereignty this interpretation is perhaps not surprising, but it must be contradicted. The sun was most likely female in origin (Mebius 2007:56f) and had similarities with Saule and a Bronze Age female counterpart.

When trying to understand Scandinavian Bronze Age mythology, perhaps it is better to look to neighbouring mythologies before drawing advanced conclusions on the basis of parallels with remote societies (e.g. Kristiansen \& Larsson 2005). Comparisons between Bronze Age Scandinavia and various Mediterranean cultures seem to cause difficulties. Previously there have been heated discussions on whether or not there were transfers of diverse cultural expressions from the eastern Mediterranean to Scandinavia. For example, a discussion about similarities between the Scandinavian symbolism and that of the Minoan culture gives indications of long-range contacts and exchange of ideas between remote societies at an elite level, thus serving as an explanation for the cultural life in Bronze Age Scandinavia. The main reason for the recent outward-looking approach is that the Bronze Age research of the last decades has been conducted from an autonomous perspective where essential parts of the past have been overlooked since research often has been limited by present-day national borders and language differences (e.g. Sherrat I994; Kristiansen I998; Larsson I999; Malmer I999; Randsborg 1999; Winter 2001; Fari 2006; Kaul 2009).

Critics for their part have claimed that such neo-diffusionist projects are flirting with Europeanism, which is not academically relevant since one cannot acquire nuanced knowledge by drawing parallels with today's global situation and asserting there was something re- 
sembling a European community during the Bronze Age (e.g. Gröhn 2004; Sjögren 2006; Nordquist 2008). However, the main purpose of recent discussions is to open up new possibilities to understand dimensions of the Bronze Age society which otherwise would be considered unreachable and therefore academically less relevant to study. This is desirable although the methods used can be discussed (Winter 2008). In the Mediterranean alone, a series of problems occur when trying to find "similarities from quite different geographical, cultural and temporal contexts" in such cases where transfers are suggested (Sjögren 2006; cf. Nordquist \& Whittaker 2007). Indeed, it can be regarded as a problem when various Mediterranean cultures are brought together in one ideological package and carried to Scandinavia where carefully selected artefacts illustrate a pan-European structure without the different cultural contexts being taken into account.

\section{OH MOTHER EARTH, THOU GRACIOUS}

Notwithstanding this, there were connections between various complex deities in the Mediterranean (cf. Marinatos 2000). At the end of the Hittite empire, a synchronization process was implemented and similar deities were grouped together and treated as equal. The Sun Goddess of Arinna was thus identified with the mother goddess Hepat, the mother of all living, although Hepat never had any solar aspects. Hepat is often depicted standing on a lion, as is also the Babylonian and Assyrian goddess Ištar, the goddess of physical love, procreation, and war. The Hittite king Hattušili III made Ištar his favourite goddess, which may seem somewhat strange since he, who was "beloved of the Sun Goddess of Arinna", married the Hurrian priestess Puduhepa 'servant of Hepat', the daughter of a priest of Ištar. In one of her prayers Puduhepa says: "In the Land of Hatti you bear the name of the Sun Goddess of Arinna; but in the land which you made the cedar land you bear the name Hepat" (Bryce 2002:287; Haas I994a:638). A later counterpart was most probably the Phrygian goddess Cybele, the fertile earth, who came to be worshiped throughout large parts of Europe for over a millennium (Burkert I979:IO2ff).

Apart from not being sun deities, none of these fertility goddesses had any links to snakes or horses. Recent attempts have been made, however, to connect the Sun Goddess of Arinna to Athena, the goddess of wisdom and justice whose main concerns were war and the protection of people. She appears in classical Greek mythology as an armed 
warrior often attended by an owl and a snake. She was the guardian of metal craft and had a strong association to weaving and the cultivation of olive trees, but to some extent she was also connected with water, ships, horses and wagons (Teffeteller 200I; cf. Luyster I965; Burkert I979:220ff; Marinatos 2000). Many of these phenomena are also known from Härnevi and the Scandinavian Bronze Age mythology. Besides the bracelets and the jingle-plates, the Härnevi hoard also includes a spearhead and an axe. As mentioned earlier, apart from the hoard Härnevi is also well known for bronze casting and therefore it is possible that the divine concept illustrated by the hoard was a guardian of metal craft. As a fruitful olive tree, Athena's tree also bears some resemblance to Saulè's life-giving tree and to Yggdrasil. However, if the Sun Goddess of Arinna can be considered as a precursor to Athena, then Athena being a daughter and not a wife to Zeus Keraunos must be seen as a later addition (Neils 200I; Tefeteller 200I).

One can wonder how far parallels may be drawn without arguments losing in strength. For the time being, I agree with Kaul (I998:26I) that "the best approach is to accept our iconography on its own terms, using foreign parallels as illustrations but not as arguments"; this is easier said than done, however. Given that fertility goddesses seem to have been of great importance in many cultures around the eastern Mediterranean, it may again be appropriate to draw attention to Tacitus' Nerthus, the Germanic Iron Age mother goddess. It has previously been suggested that Nerthus could be a counterpart of Cybele ( $c f$. Näsström I995:23 ff). As it is possible to observe a greater female presence during the Bronze Age with an increased frequency of jewellery and female bronze figurines, Nerthus has several times come to be mentioned as a goddess of fertility introduced during the Late Bronze Age. Such an assumption also seems to have been necessary since previously it has been taken for granted that the sun was masculine and not feminine (e.g. Montelius I900; Helander 1906; Arne 1909; Bjørn I 924:7ff; Almgren I927; Davidson I969; Görman I989; Kaul 2009).

\section{THE ALL-POWERFUL GODDESS}

When studying Norse mythology, it is possible to see connections between different gods assembled in holy units. This may be consistent in the spatial distribution pattern of deities in place names. "Njärd, which is the Scandinavian variant of Nerthus, constitutes most often the female part of those holy couples, but in the north-east Mälaren 
region she is replaced by Härn (Olsen I9I 5; Wessén I923). Njärd has in turn been associated with Freyja since the father of Freyja and Freyr was Njorðr, one of the Vanir who were a distinguished group of divinities in Norse mythology foremost associated with fertility. Closely connected to the Vanir was the expression til árs ok friðar 'for a good year's crop and peace', which is equivalent to Tacitus' expression pax et quies. Both Freyr and Freyja seem to have been the main divinities of fertility. It has been suggested that their names from the beginning functioned as titles meaning 'lord' and 'lady' and that Njorðr and Njärd were the real names of this divine couple. Consequently they were named Njorðr freyr and Njärd freyja (Kock I 896). In Sweden Njorðr is often exchanged with Ullr in the place-name material, and possibly Freyr and Ullr were one and the same god, Ullr freyr (Grimnismál $5 \mathrm{I}$ ). In The Poetic Edda, Ullr is depicted as the stepson of the thunder god Thor and thus has a somewhat similar position as the Baltic moon god Menulis who is the son-in-law of Dievas Perkūnas. Interestingly enough, the nearest theophoric place name to Härnevi is Torslunda in Torstuna parish to the north, and this spatial relation between Thor and Härn is of utmost interest with regard to what is known from other mythologies. I want to stress the possibility that the Bronze Age mythology included other celestial deities than only the sun, even though the sun probably was at the centre of much religious worship.

Interesting but definitely not unproblematic relationships between various deities do not seem to stop here. A tenable connection between the goddesses Freyja and Frigg can be noted. Through Snorre, we know that Frigg is the first among Ásynjur, but that Freyja is tígnuz með 'the most prominent together with' Frigg. Sometimes Freyja is even ágæetust of ásynjum 'the most excellent of the goddesses' (Näsström I995:I04f). An attempt to problematize this connection has been made (Grundy I996), but if other materials are considered as well, and if descriptions of Frigg and Freyja are compared, there emerges an indication of a common origin (Näsström I995:I06ff). Simply the fact that both are married to Óðinn and Oðr, respectively, results in this possibility. This cannot be easily ignored because there is not much doubt that the husbands, too, were originally the same god (Näsström I995:8 If, II3).

Tales about Óðinn chasing a female being with flowing hair and sagging breasts through forests and across the sky can be found in folklore material. In Swedish folklore she is named Skogsrået 'lady ruler of the 
forest' and Huldra 'the hidden one' in Norwegian (Granberg 1935). The name Huldra resembles Hulðr Seiðkonu in Heimskringla and Frau Hulda in German folklore, of which the latter has been connected with Freyja. Freyja, for her part, is the goddess of seið and she taught this practice to Frigg and Óðinn (Näsström I995:8 2f, 2 Ioff). Possibly, Skogsrået can in some tales be considered a successor to Freyja.

The traditions of Skogsrået were examined by Gunnar Granberg in his doctoral dissertation from I 935 . However, one tradition of interest in the context of this paper has not been recorded. This tale comes from the southern part of Torstuna parish nearby Härnevi and partly reflects some of the concepts discussed above. "Då en ä ute å går i skogen, ska en noga aktas för te jöra illa skogsrån för on uppenbarer se på många olika vis. Iblann visar hon se som en orm, iblann som en ormila, iblann som en groda. För jägare visar hon se iblann som en vacker flicka, men ryggin är urholka som en svinho. Dömmerså får en lov te vara försiktin me ormar å ormilor" "When someone is out in the forest, they should be careful not to upset Skogsraiet, because she appears in many different ways. Sometimes she appears as a snake, sometimes as a slow-worm, and sometimes as a frog. To hunters, she sometimes appears as a beautiful girl, but her back is hollow as a pig's trough. Judge thereafter: one must be careful with snakes and slow-worms" (Bladh et al. 1979:353, my translation). In addition to the link between Skogsrået and snakes, it was typical of frogs in old traditions to be regarded as symbols of fertility and childbirth (Lövenkrona I989).

\section{TRAVELLING BACK AND FORTH}

For me it is not impossible to picture the Härnevi hoard as the material remains of a ceremony representing the sun's journey across the sky. If one considers the association to fertility, this hoard could also be interpreted as a metaphor for the cycle of life which was part of an ideology in which the seasonal coming, disappearing and recurring were expressed through conceptions regarding agriculture (Forsgren 2008:22; cf. Thedéen 2003). When taking the artefacts and their symbolic associations into consideration, an image of a sun goddess with roots in the Bronze Age emerges. Since this divine concept appears in a place called Härnevi, I argue that Härn was the name of this goddess in Uppland. It is indeed possible that the artefacts in the Härnevi hoard were used by someone who assumed the identity of a goddess, and in that case it is also possible to discern ritual activities in Härnevi, which 
is suitable since the last element of the place name refers to a sanctuary of peace and prosperity (Forsgren 2007, 2008).

Several of the artefacts in the hoard have their symbolic counterparts elsewhere and suggest that Härn as well as her parallels was complex in character. Spears, daggers and axes are evocative of war, while sickles are rather reminiscent of crops. Thus, this hoard was a tangible manifestation of the expression til árs ok friðar (Forsgren 2008:22f). Härn would thus have been a goddess who was associated with both war and peace in a similar manner as the Sun Goddess of Arinna, Athena and Nerthus. That these goddesses along with Saule had links to the World Tree further underlines their role as fertility goddesses ( $c f$. Freyja's fruit tree, Näsström I995:2 I3). Through comparative parallels it is also possible to see strong links to a god of thunder, which is interesting since the nearest parish to Härnevi is Torstuna.

One of the key problems in my paper is to try to understand the relation between the sun and fertility. In particular, two types of objects indicate that Härn can probably be considered a sun goddess in a cosmic myth, namely the spiral-inclined bracelets with s-shaped terminals and snake pattern, and the jingle-plates which refer to both horses and the sun. This symbolism is also found in the Bronze Age cosmological myths that people during this period most likely apprehended (Kaul I998). In the Mediterranean, however, it is easily noted that fertility aspects dominated regarding the great goddess while at the same time the sun was perceived as masculine. Yet this does not apply to north-west Europe where the sun instead was perceived as feminine (West 2007).

A tentative hypothesis can be put forth which possibly also can explain the relation between Härn and Njärd Freyja. An assumption can be made that the various fertility goddesses around the Mediterranean were variants of each other and that at least one of them inspired the concepts of the Germanic goddess Nerthus and a former Celtic counterpart (cf. Görman I989). A further assumption is that during the end of the Stone Age or Early Bronze Age a new mythology was slowly introduced into southern Scandinavia and the Baltic, influenced by Indo-European cultures, but a sun goddess common to all people of northern Europe was continuously being worshiped (cf. Mandt I986). During the course of the Bronze Age more and more influences from the Celtic world can be noticed, but the belief in the sun goddess continued. In the transition to the Celtic Iron Age, the focus switched for some reason to the worship of a more specialized fertility goddess who 
came to be referred to as Njärd Freyja. This hypothesis requires future research, but nevertheless it should be noted that Freyja, too, had links to the sun which is underlined by the following verse:

"Seij nu Torkar svar igen, han skal aldrig hammarn få, för ähn jag fåhr Jungfru Froijenborg, den vähna solen tå”

"Trolltram sänder dig svahr igen, du kan eij hammaren få, för ähn han fåhr Jungfru Froijenborg, den vähna solen tå”

"Answer Thor once again, that he never will receive the hammer until I have the maid Freyja, the fair sun then."

"Trymer is sending you an answer again, you cannot receive the hammer until he gets the maid Freyja, the fair sun then."

(from the Swedish song Hammar-Hemtningen. Arwidsson I 834, my translation)

\section{Acknowledgment}

I wish to thank Christina Karlsson, University of Southampton, for encouragement, and Martin Hansson and Laura Wrang for the great help to achieve the final result. Many thanks as well to Ingmar Jansson for having been a wonderful supervisor during the writing of my seminar papers. Anna Källén is recognized for having read a later version during Thesis II. 


\section{References}

Andrén, A. 2004a. Mission Impossible? The Archaeology of Norse Religion. In: Insoll, T. (Ed). Belief in the Past. BAR International Series I 2 I 2. Pp. 7-I6. Oxford: Archaeopress.

- 2004b. I skuggan av Yggdrasil. Trädet mellan idé och realitet i nordisk tradition. In: Andrén, A., Jennbert, K. \& Raudvere, C. (Eds.). Ordning mot kaos. Studier av nordisk förkristen kosmologi. Vägar till Midgård 4. Pp. 389-430. Lund: Nordic Academic Press.

Anthony, D. W. 2007. The Horse, the Wheel, and Language. How the Bronze-Age Riders from the Eurasian Steppes Shaped the Modern World. Princeton: Princ. Univ. Press.

Almgren, O. I927. Hällristningar och kultbruk. Bidrag till belysning av de nordiska bronsåldersristningarnas innebörd. KVHAA handlingar 35. Stockholm: Wahlström \& Widstrand.

Arne, T. J. I909. Några i Sverige funna bronsstatyetter af barbarisk tillverkning. Fornvännen. Vol. 4. Pp. I75-I 87.

Arwidsson, A. I. I834. Svenska fornsånger. En samling af kämpavisor, folk-visor, lekar och dansar samt barn- och vall-sanger. Stockholm: Norstedt.

Biezais, H. I975. Baltische religion. In: Ström, Å. \& Biezais, H. (Eds). Germanische und Baltische Religion. Die Religionen der Menschheit I9: I. Stuttgart: Kohlhammer.

- I976. Lichtgott der alten Letten. Scripta Instituti Donneriani Aboensis 8. Stockholm: Almqvist \& Wiksell International.

- I987. Baltic religion. The Encyclopedia of Religion. Vol. 2. Eliade, M. (Ed). Pp. 49-55. New York: Macmillan.

Bjørn, A. 1924. Gudinden med halsringen. Ett fragment. In: Haug og Museum. Til A.W. Brøgger, 40 Aars-Dagen. Pp. 7-I3. Kristiania [Oslo]: Universitetets Oldsamling.

Bladh, A. et al. I979. Tre sockenkrönikor. Härnevi, Torstuna, Österunda. Enköping: Härnevi hembygdsförening.

Bryce, T. 2002. Life and Society in the Hittite World. Oxford: Oxf. Univ. Press.

Brøndsted, J. 1938. Bronzealderens soldyrkelse. Copenhagen: repr.

Burkert, W. I979. Structure and History in Greek Mythology and Ritual. Berkeley: Univ. of Calif. Press.

Bäck, M., Hållans Stenholm, A-M., Ljung, J-Å. 2008. Lilla Ullevi- historien om det fridlysta rummet. UV Mitt. Hägersten: Riksantikvarieämbetet.

la Cour, V. 1924. Solens personifikation i vor Broncealder. Danske Studier I924. Pp. I2I-I34.

Davidson, H. R. E. 1969. The Chariot of the Sun. Folklore. Vol. 80. Pp. I74-I80.

Ekblom, J. E. I 872. Beskrifning öfver Hernevi socken. Enköping: C.E. Eriksson.

Ekholm, G. I92 I. Studier i Upplands bebyggelsehistoria. Bronsålder. Uppsala: Akad. bokh.

Elmevik, L. 1995. Härnevi och Friggeåker. Namn och bygd. Vol. 83. Pp. 67-77.

Fari, C. H. 2006. Hieros-gamos. En sammenligning mellom symbolets uttrykk i den nordiske bronsealderens helleristningstradisjon og myteverdenenn i det østlige middelhavsområdet. In: Prescott, C. (Ed). Myter og religion ibronsealderen. Oslo archaeological series 5. Oslo: Institutt for ark., kunsthist. og konserv. 
Forsgren, M. 2007. Depåfyndet från Härnevi, del I. Föremålsförståelse och genusperspektiv med utgångspunkt frän ett s.k. skrotfynd frän yngre bronsailder $i$ Uppland. BA thesis in archaeology. Stockholm University.

- 2008. Depåfyndet från Härnevi, del II. Sammanhang och förståelse av en fragmenterad bronsdepå i torrmark frain yngre bronsailder i Uppland. MA thesis in archaeology. Stockholm University.

Granberg, G. 1935. Skogsrået i yngre nordisk folktradition. Skrifter utg. av Kungl. Gustav Adolfs akademien för folklivsforskning 3 . Uppsala: Lundequistska bokh.

Grau, O. I754. Beskrifning öfwer Wästmanland med sina städer, härader och socknar. Västerås.

Grundy, S. 1996. Freyja and Frigg. In: Billington, S. \& Green, M. The Concept of the Goddess. Pp. 56-67. London \& New York: Routledge.

Gröhn, A. 2004. Positioning the Bronze Age in Social Theory and Research Context. Acta Archaeologica Lundensia. Series in $8^{\circ}$ 47. Stockholm: Almqvist \& Wiksell.

Gurney, O. R. 1977. Some Aspects of Hittite Religion. Oxford: Publ. for The British Academy by Oxf. Univ. Press.

Görman, M. 1989. Nordiskt och keltiskt. Sydskandinavisk religion under yngre bronsålder och keltisk järnålder. Lund: cop.

Haas, V. I994a. Geschichte der hethitischen Religion. Leiden: E. J. Brill.

- I994b. Das Pferd in der hethitischen religiösen Überlieferung. In: Hänsel, B. \& Zimmer, S. (Eds). Die Indogermanen und das Pferd. Pp. 77-90. Budapest: Archaeolingua Alapítvány.

Helander, J. I906. Den svenske solguden och den svenske Tyr. Ord och bild. Pp. I76-I94.

Hellberg, L. I986. Hedendomens spår i Uppländska ortnamn. Ortnamnssällskapets i Uppsala årsskrift I986. Pp. 40-7I.

Hildebrand, H. I899. Sveriges medeltid 3. Stockholm: Gidlund.

Kaul, F. 1998. Ships on Bronzes. A Study in Bronze Age Religion and Iconography. Copenhagen: National Museum.

- 2009. En solguds mange skikkelser. En mystisk kosmologisk rejse. In: Nationalmuseets Arbejdsmark 2009. Copenhagen: National Museum.

Kock, A. I896. Die Göttin Nerthus und der Gott Njorðr. Zeitschrift für Deutsche Philologie. Vol. 28. Pp. 289-294.

Kokare, E. 1996. A Survey of the Basic Structures in Latvian Mythology. Journal of the Baltic Institute of Folklore. Vol. I. http://www.folklore.ee/rl/pubte/ee/ bif/bifı/sisu.html.

Kraft, J. I999. Hednagudar och hövdingadömen i det gamla Skandinavien. Upplands-Bro: cop.

Kristiansen, K. 1998. Europe Before History. Cambridge: Camb. Univ. Press.

Kristiansen, K. \& Larsson, T. B. 2005 . The Rise of Bronze Age Society. Travels, Transmissions and Transformations. Cambridge: Camb. Univ. Press.

Larsson, T. B. I999. The Transmission of an Elite Ideology. Europe and the Near East in the Second Millennium BC. In: Goldhahn, J. (Ed). Rock Art as Social Representation. BAR International Series 794. Pp. 49-64. Oxford: Archaeopress.

Lang, V. 2007. The Bronze Age and Early Iron Age in Estonia. Tartu: Tartu Univ. Press.

Lindeberg, M. 1997. Gold, Gods and Women. Current Swedish Archaeology. Vol. 5. Pp. 99-i Iо. 
Lindroth, H. I9I 5 . Härnevi. Ett bidrag till frågan om beröringen mellan svensk och finsk mytologi. Namn och bygd. Vol. 3. Pp. 57-9I.

Luik, H. \& Ots, M. 2007. Bronze Age Double Buttons in Estonia. Estonian Journal of Archaeology. Vol. I I. Pp. I22-I 40.

Lundberg, O. I9I2. Härnevi och därmed sammanhängande ortnamn. Om nordisk fruktbarhetskult. In: Lundberg, O. \& Sperber, H. (Eds). Härnevi. Pp. 3-40. Uppsala: Uppsala univ. årsskrift.

Luven, Y. 200I. Der Kult der Hausschlange. Eine Studie zur Religionsgeschichte der Letten und Litauen. Quellen und Studien zur baltischen Geschichte I7. Köln: Böhlau.

Luyster, R. I965. Symbolic Elements in the Cult of Athena. History of Religions. Vol. 5. Pp.I33-I63.

Lövenkrona, I. 1989. The Pregnant Frog and the Farmer's Wife. Childbirth in the Middle Ages as Shown Through a Legend. ARV. Scandinavian yearbook offolklore I989. Pp. 73-I24. Stockholm: Gustav Adolfs akademien.

Malmer, M. I999. How and Why did Greece Communicate with Scandinavia in the Bronze Age? In: Orrling, C. (Ed). Communication in Bronze Age Europe. Pp. 33-42. Stockholm: Historiska museet.

Mandt, G. 1986. Searching for Female Deities in the Religious Manifestations of the Scandinavian Bronze Age. In: Steinsland, G. (Ed). Words and Objects. Towards a Dialogue between Archaeology and History of Religion. Pp. I I I-I 26. Oslo: Norw. Univ. Press.

Marinatos, N. 2000. The Goddess and the Warrior. The Naked Goddess and Mistress of Animals in Early Greek Religion. London: Routledge.

Mebius, H. 2003. Bissie. Studier i samisk religionshistoria. Östersund: Jengel.

Montelius, O. I 887. Ett fynd från Eskelhems Prestgård på Gotland. KVHAA Månadsblad. Vol. I6. Pp. I45-I79.

- I900. Solgudens yxa och Tors hammare. Svenska fornminnesföreningens tidskrift. Vol. ro. Pp. 277-296.

Neils, J. 200 I. Athena, Alter Ego of Zeus. In: Deacy, S. \& Villing, A. (Eds). Athena in the Classical World. Pp. 219-232. Leiden: Brill.

Nordquist, G. 2008. Perspectives on the "Bronze Age". In: Whittaker, H. (Ed). The Aegean Bronze Age in Relation to the Wider European Context. BAR International Series I745. Pp. 95-I03. Oxford: Archaeopress.

Nordqust, G. \& Whittaker,H. 2007. Comments on Kristian Kristiansen and Thomas B. Larsson (2005): The Rise of Bronze Age Society. Travels, Transmissions and Transformations, Cambridge. Norwegian Archaeological Review. Vol. 40. Pp. $75^{-84}$.

Näsström, B-M. I995. Freyja. The Great Goddess of the North. Lund studies in history of religion 5. Stockholm. Almqvist \& Wiksell.

Olsen, M. 1908. Hoernavi. En gammel svensk og norsk gudinde. Christiania videnskabs-selskabs forhandlingar for I908, 6. Christiania [Oslo]: Kulturorgan Skadinaujo.

- I9I 5. Hedenske kultminder i norske stedsnavne. Christiania [Oslo]: J. Dybwad i kommission.

Olrik, A. 1905. Nordisk og lappisk gudsdyrkelse. Bemerkninger i anledning af solvognen fra Trundholm. Danske studier I905. Pp. 39-57.

Puhvel, J. 1974. Indo-European Structure of the Baltic Pantheon. In: Larson, G. J. (Ed). Myth in Indo-European Antiquity. Pp. 75-8 5 . Berkeley: Univ. of Cal. Press. 
Randsborg, K. I999. Kivik Power of Communication. In: Orrling, C. (Ed). Communication in Bronze Age Europe. Pp. 22-32. Stockholm: Historiska museet.

Robbins Dexter, M. 1984. Proto-Indo-European Sun Maidens and Gods of the Moon. Mankind Quarterly. Vol. 25. Pp. I37-I 44.

- I990. Whence the Goddesses. A Source Book. New York: Pergamon Press.

Sahlgren, J. I952. Härads- och sockennamnen. Sveriges bebyggelse. Statistik-topografisk beskrivning över Sveriges städer och landsbygd. Landsbygden. Uddevalla: Hermes.

Sherrat, A. 1994. What Would a Bronze Age World System Look Like? Journal of European Archaeology. Vol. I. Pp. I-58.

Sjögren, J. 2006. Minoan Wannabees. The Resurrection of Minoan Influences in Scandinavian Archaeology. Momigliano, N. \& Hamilakis, Y. (Eds). Archaeology and European modernity. Producing and consuming the 'Minoans'. Creta antica 7. Pp. I27-I42. Padova: Bottega d'Erasmo.

Sperber, H. I9I 2. Härnevi. Vermutungen über die Etymologie von aschw. Hærn, aisl. Hørn. N: Lundberg O. \& Sperber, H. Härnevi. Pp. 4 I-49. Uppsala: Upps. Univ. årsskrift.

Sturluson, S. I9I6. The Prose Edda. Gilchrist Brodeur, A. (transl.). New York: The American-Scandinavian Foundation.

Sundqvist, O. 2007. Kultledare ifornskandinavisk religion. OPIA 4I. Uppsala: Upps. Univ.

Tacitus, C. 1999 [ca 98 AD]. Germania. De Origine et situ Germanorum (orig.). Rives, J. B. (transl.). I999. Oxford: Clarendon.

Taffeteller, A. 200 I. Greek Athena and the Hittite Sungoddess of Arinna. In: Deacy, S. \& Villing, A. (Eds). Athena in the Classical World. Pp. 349-365. Leiden: Brill.

Thedéen, S. 2003. Life Course Practices in Bronze Age Landscapes of East Central Sweden. Beyond Devine Chiefs and Neodiffusionism. Current Swedish Archaeology. Vol. I I. Pp. 97-I I 8.

The Poetic Edda. 1999. Larrington, C. (transl.). Oxford: Oxf. Univ. Press.

Tvauri, A. 1999. Cup-marked Stones in Estonia. Electronic Journal of Folklore. Vol. I I. http://www.folklore.ee/Folklore/ksisu.htm

Vikstrand, P. 200I. Gudarnas platser. Förkristna sakrala ortnamn i mälarlandskapen. Acta Academiae Regiae Gustavi Adolph 77. Studier till en svensk ortnamnsatlas I7. Uppsala: Kungl. Gustav Adolfs akademien för svensk folkkultur.

de Vries, J. I935. Altgermanische Religionsgeschichte, Bd I. Einleitung, Die vorgeschichtliche Zeit, Religion der Südgermanen. Grundriss der germanischen Philologie I2:I. Berlin: Gruyter.

West, M. L. 2007. Indo-European Poetry and Myth. Oxford: Oxf. Univ. Press.

Wessén, E. I 923. Minnen av forntida gudsdyrkan i Mellan-Sveriges ortnamn. Studier inordisk filologi. Vol. I4. Pp. I-26.

Winter, L. 200I. Cultural Encounters. Symbols from the Mediterranean World in the South Scandinavian Rock Carving Tradition During the Bronze Age. In: Werbart, B. (Ed). Cultural Interactions in Europe and the eastern Mediterranean during the Bronze Age (3000-500 BC). BAR International Series 985. Pp. 9-28. Oxford: Archaeopress.

- 2008. From Diffusion to Interaction. Connections Between the Nordic Area and Valcamonica During the First Millennium BC. In: Whittaker, H. (Ed). The Aegean Bronze Age in Relation to the Wider European Context. BAR International Series I745. Pp. 35-55. Oxford: Archaeopress. 



\section{THE MYTHICAL FORGE AND THE HOLY CHAPEL}

\section{From paganism to Christianity at the manorial farm in Lockarp, Scania}

Olle Heimer

\begin{abstract}
Several archaeological investigations have taken place in the village of Lockarp, just south of Malmö, Scania. These investigations have revealed the remains of a large Viking Age and early medieval farm, or manor. The aim of this article is to discuss the transition from paganism to Christianity on the basis of two buildings in the Lockarp manor that are interpreted as a forge and a chapel. The buildings were situated inside a courtyard, in what was interpreted as the private, innermost area of the manor. The author describes the manor's social status and the location of these two buildings, and discusses whether the buildings are visible signs of the religious transition.
\end{abstract}

Key words: aristocracy, chapel, forge, hall, manor, medieval time, Viking Age

\section{INTRODUCTION}

In recent years, the interest in aristocratic locations and central places from the Late Iron Age has increased among scholars within Iron Age research. A number of these locations have been examined archaeologically and thus the knowledge of these places has grown and the results have been published. Now the remains of yet another aristocratic location, a manor that was established in the tenth century, have been excavated. The site of the excavation is Lockarp, just south of Malmö in Scania, Sweden (Heimer et al. 2006; Heimer \& Persson 2007; Björhem 
et al. 2008; Heimer 2009). The remains of the manor revealed different social environments, such as a workshop area, a possible garrison, and a residence suitable for an aristocrat. In the middle of the residence were traces of a forge and a chapel. The aim of this paper is to discuss the manor at Lockarp and the transition from paganism to Christianity in the light of these two centrally placed buildings.

\section{TOPOGRAPHY AND STRATEGIC LOCATION}

The manor was located on the western side of a ridge approximately 39 metres above sea level (fig. I). During the Early Middle Ages the ridge was probably more dominant than today, but having been used for hundreds of years as a sand-pit it has diminished substantially. Despite this, the area, with its height, stands out rather well in the landscape even today. The manor was situated along the road running between Oxie, the royal estate where the thing council was held, and the

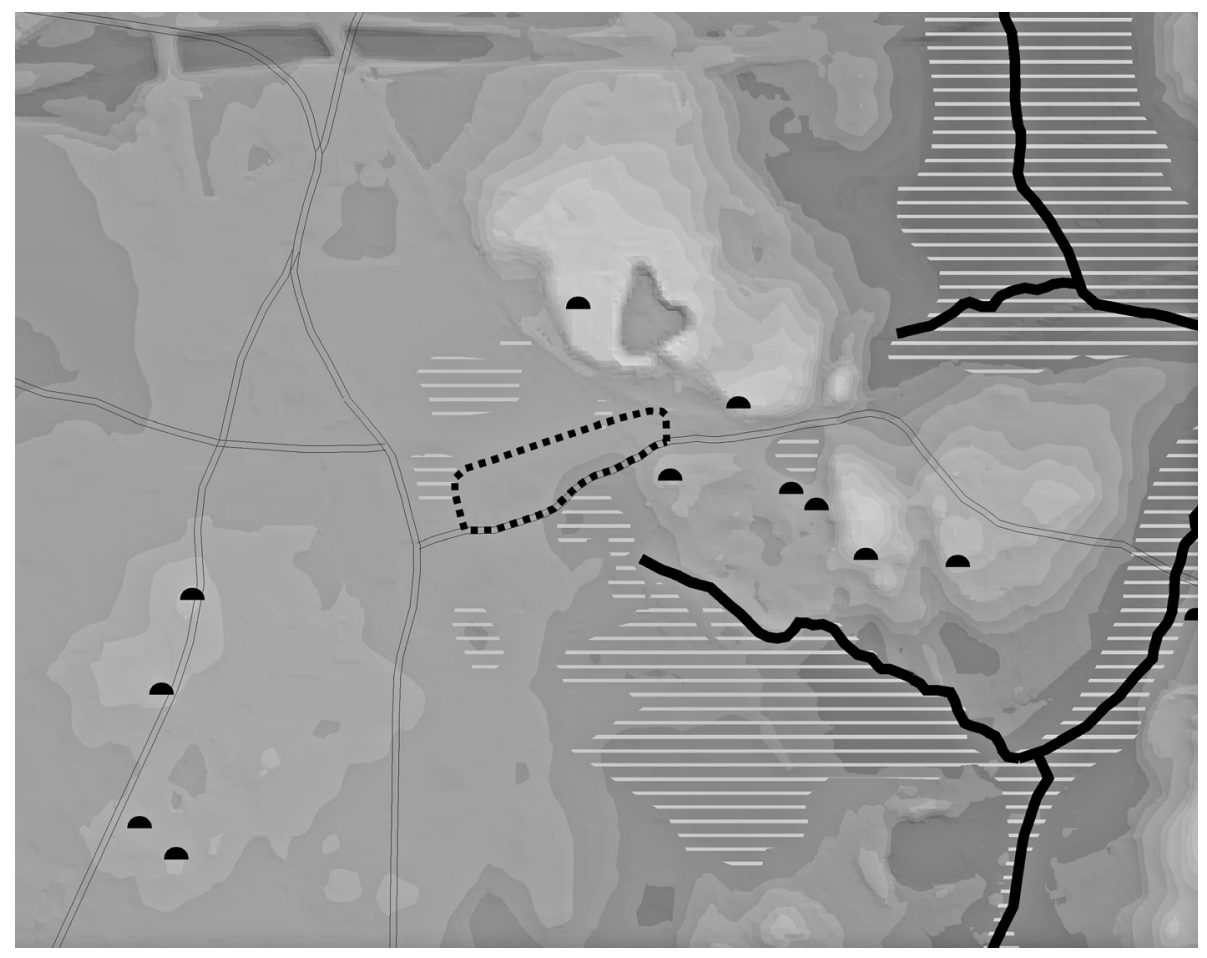

Figure I. The map shows the topographical location of the manor in Lockarp. Semicircles mark burial mounds. Roads, the stream Risebergabäcken, meadows and wetlands (hatched) are digitalized from historical maps. Modern disturbances are visible in the form of highways and railways. Directly north-east of the manor the ridge has been used as a sand pit. Scale I:20 o00. 
market place at Hököpinge. One of the intentions with the location of the manor could have been to supervise this road.

The topographical location is central to the discussion of the manor, and it is worth looking closer at the social importance of the manor and its more or less command-post-like location. From this position, the manor dominated the visual landscape west of the ridge. Such arrangements were typical for many central places. The strategic location was primarily a means to gain control, as access and movement within the settlements could be monitored from this position. The central places were often separated from the other settlements and lay in connection to important communication routes (Thomasson 2005:85f). To emphasize that one entered a central place, certain elements were placed along its boundaries, its entrances and exits. The link between the manor and intersections was most likely an important strategy (Lundqvist 2000:20f). It is noteworthy that the Lockarp manor was located by the road leading to the ford or bridge over Risebergabäcken.

\section{TO BE CLOSE TO THE MYTHICAL ANCESTORS}

The location of the farm can also have been influenced by the earlier use of the area. Remarkable is that part of the manor was established on a Bronze Age burial ground. Whether the graves were in some way marked above ground and visible when the manor was found can of course be discussed, but it is not likely. Three burial mounds, however, were clearly visible on the ridge north and east and south of the manor, two of them still visible today. Just south of the manor lay yet another mound that is now destroyed due to modern agriculture. Thus, when one passed the manor in the Early Middle Ages, there were burial mounds on both sides of the road (figs. I, 2.). The establishment of a manor on an ancient burial ground can be interpreted as an important link between the aristocrat and his or her ancestors. In examined materials of large farms with halls, there is a tendency for them to be established at places linked to older sacrificial practices and to graves. By building a hall at a place connected to an older cult, a link was established to the actions of the cult that were associated with extraordinary qualities. In that way the aristocracy was connected to a traditional ritual praxis (Söderberg 2005:I9If).

\section{FROM A FARM TO A MANOR}

During the Viking Age, around AD 900, the area that would later be- 


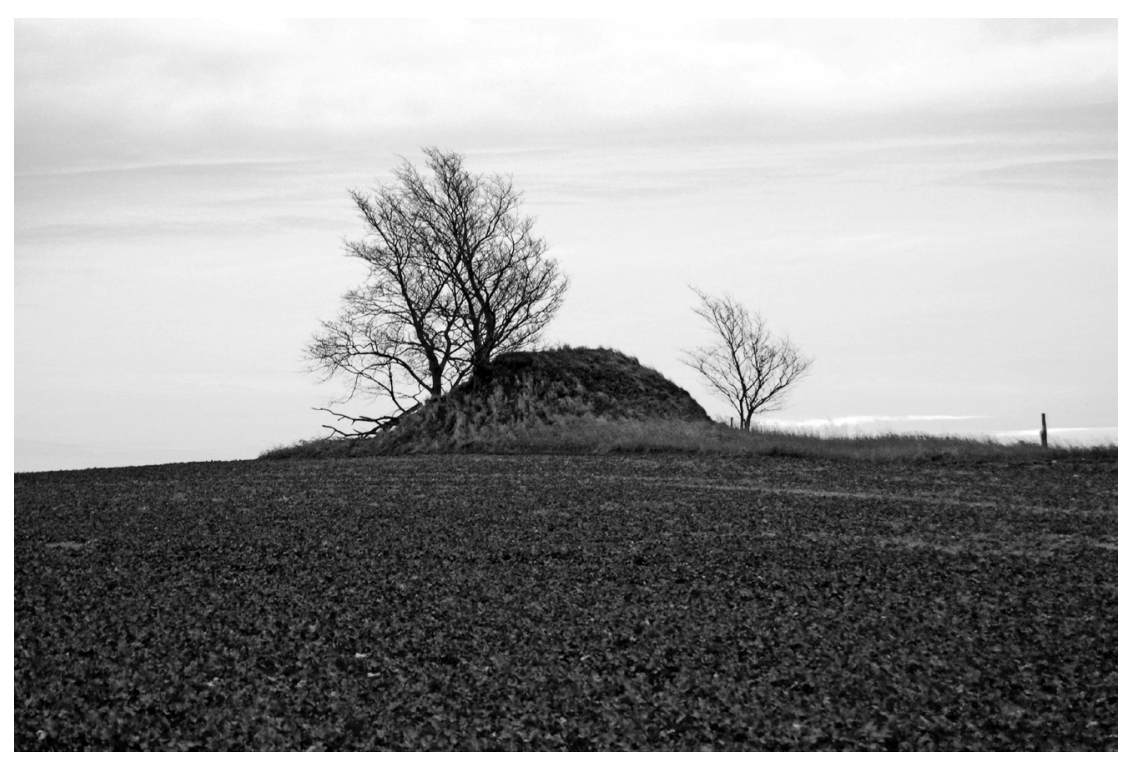

Figure 2. The burial mound Skrivarehög located just east of the manor.

Photo: Olle Heimer.

come the manor site was occupied by a single, large farm (fig. 3 A.). The farm differed from those in other surveys in Denmark, for example Vorbasse and Sædding on Jutland where the farm structure consisted of a relatively loosely grouped settlement (Roesdahl I980:67f; Ethelberg 2003:353f). The farm in Lockarp seems to have formed a U-shaped structure, where the buildings lay grouped around an open place, an architectural unit. This was a relatively large Viking Age farm with a workshop area placed to the west of the main buildings. In the workshop area there was a forge as well as sunken dwellings for handicraft (Heimer \& Persson 2007; Björhem et al. 2008). Around AD 950-1000, extensive changes took place in Lockarp (fig. 3 B). From having been a relatively large farm, suitable for a Viking Age chieftain, the settlement now become an aristocratic manor with more prestigious buildings such as a hall, residential buildings, a forge, stables, barns, and other farm buildings. The main house of the farm moved approximately 200 metres to the east and was established on an ancient burial ground. During the Early Middle Ages, around AD Ioo०-I Ioo, the manor was consolidated and strengthened (fig. $3 \mathrm{C}$ ). The old hall was torn down and replaced with a new and larger building. South of the hall, four buildings were built to create an almost rectangular block with a forge placed in the courtyard. During the later part of the phase the work- 
shop was replaced with a chapel (mentioned below in the sections "The mythical forge" and "The holy chapel"). Around AD I I00-I 200 the farm underwent further changes (fig. $3 \mathrm{D}$ ). The previous manor was divided into what later would become the historically known farms in Lockarp, but the previous hall area was still distinguished by its position and prestigious architecture.
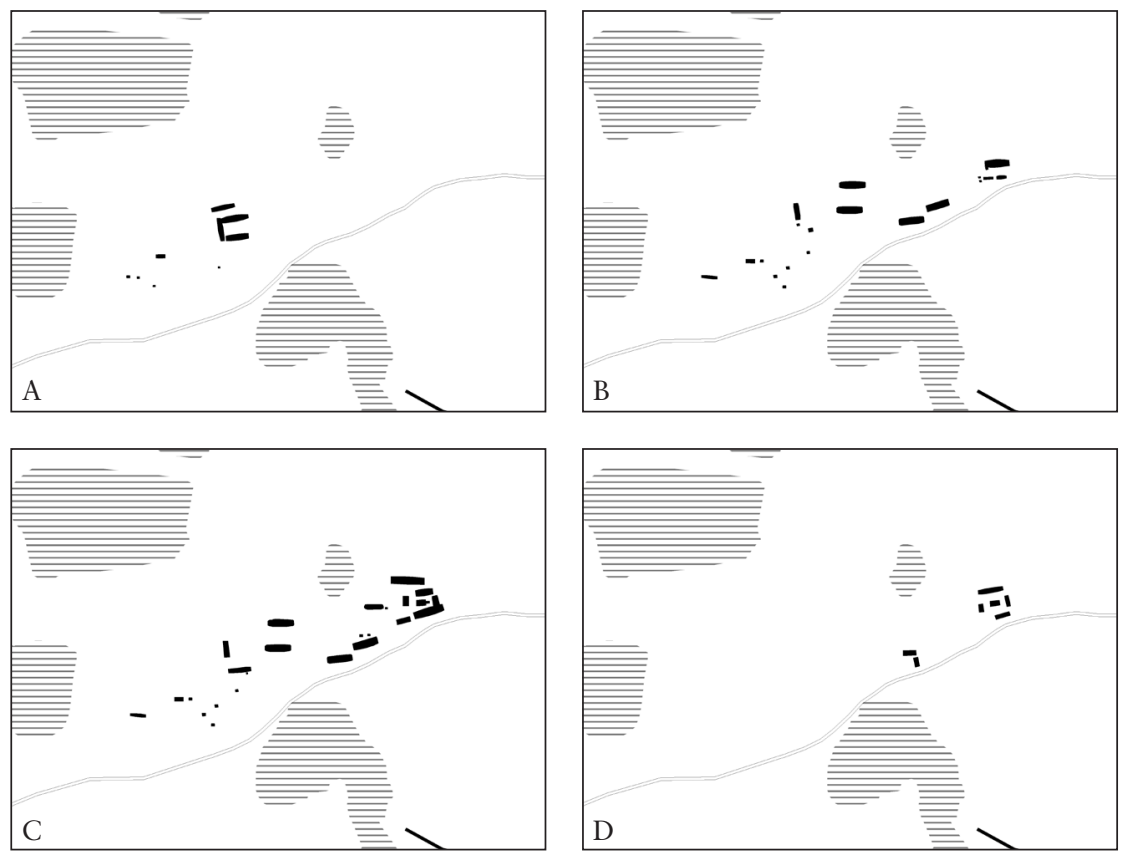

Figure 3. The figure shows the development of the farm in Lockarp from around AD 900 to I200. A. around $\mathrm{AD} 900, \mathrm{~B}$. around $\mathrm{AD} 950-1000, \mathrm{C}$. around $\mathrm{AD}$ I000-II00, and D. around $\mathrm{AD}$ I IOO-I 200. No scale.

\section{THE RULER'S RESIDENCE AND THE}

\section{EXCLUSIVE ARCHITECTURE}

The residence consisted of three elements: the main building with the hall, a fence with a stockade in the eastern part, and the residential buildings that formed a closed unit, almost a square, with a smaller house in the middle. The small house was initially a workshop or a forge but later was rebuilt to serve as a chapel (fig. 4).

The architecture in Lockarp had several aristocratic key signatures. Houses with outer rows of supporting posts, so-called Trelleborg-type 


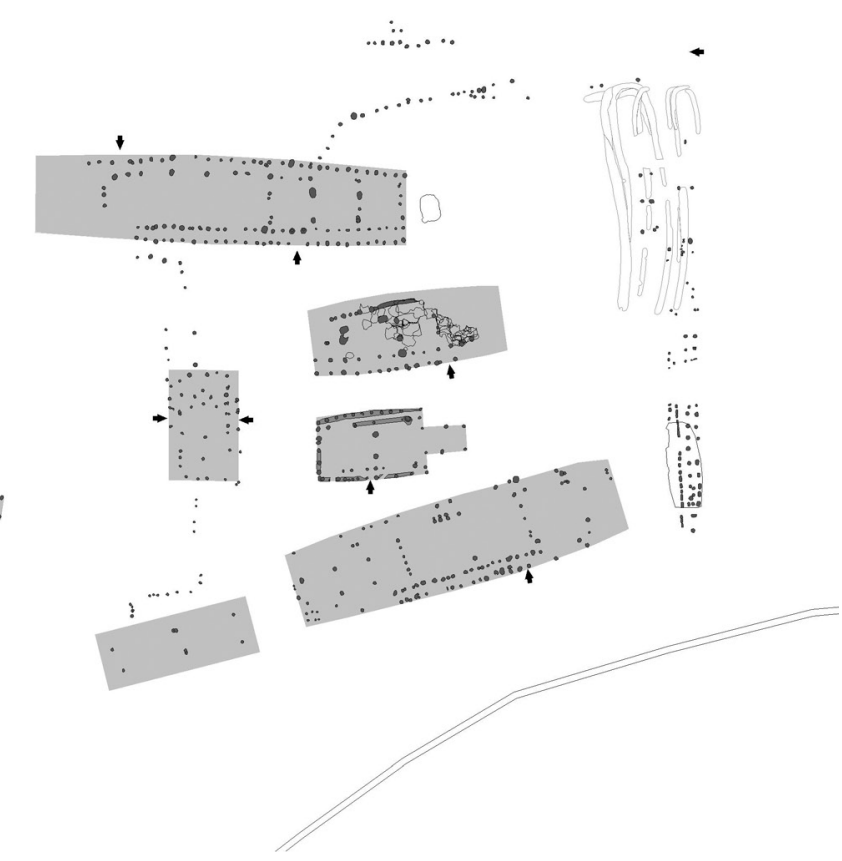

Figure 4. The residence in Lockarp during the Early Middle Ages, c. AD I000-I05०. Scale I:I000.

houses, can be interpreted as an expression of the proprietor's status and strong connection to the Danish royal power. Houses with outer rows of supporting posts were built in south Scandinavia more or less directly after the rise of the circular fortresses in the late soth century. Thus, it was probably natural and desirable for the local chieftains to elucidate their own position by using the design of the royal power and building their houses according to the new ideals (Wranning I999:48). It is possible that the foundation of the manor in Lockarp was inspired by these circular fortresses. In the fortress of Trelleborg on Zealand and that of Fyrkat on Jutland the buildings were constructed with the same ground plan, arranged in a square with a smaller house in the middle (Nørlund I948:90f; Roesdahl I977:I76ff; Wulff Andersen I998:I9). The manor in Lockarp can also be compared with other excavated Viking Age farms in south Scandinavia, such as Ösarp in Halland. The remains of the farm in Ösarp were interpreted as a large estate from the late I Ith century (Viking \& Fors I995:73ff; Carlie I999: I36). As in Lockarp, the farm at Ösarp consisted of several farm buildings, all built in the same way as in Lockarp, with outer rows of supporting posts. In addition to these buildings a structure interpreted as a forge 
was excavated. The forge shows similarities to the forge in Lockarp (mentioned below in the chapter "The mythical forge"). The buildings were complex constructions that demanded great craftsmanship and large amounts of building material. These buildings were probably built with oak in the supporting construction. The walls were not of wattle and daub but of oak planks, and the roof was made of wooden chips and not of straw, which probably was the more common material. The choice to use oak timber as building material was something that marked the economic strength of the property developer. Building in this material demanded great access to timber. The enclosed manor in Lockarp was the embodiment of social power. The building with outer rows of supporting posts was a signal of the owner's identity as a member of the aristocracy and the close contact with the royal power.

According to the Norwegian professor in architectural history and theory Thomas Thiis-Evensen, there are six elements that run through the buildings of power in history. These are seclusion, massiveness, size, distance, symmetry and verticality (Thiis-Evensen I998:6ff). Not all of these six elements have to be present to give a place or a building the impression of being powerful. It can be enough that a small building is placed higher than the surrounding buildings to create an impression of power. A massive castle does not have to be symmetrical to express power (Thiis-Evensen I998:I3; Hed Jakobson 2003:43f).

The enclosed part of the manor in Lockarp, however, shows all six elements presented by Thiis-Evensen:

- It was secluded in the way that it was enclosed. Only invited persons had access to the closed part of the manor.

- The buildings with outer rows of supporting posts (so-called Trelleborg-type houses) and the enclosure were associated with something firm, massive, impregnable and permanent.

- The size makes power visible in Lockarp. It was the hall building and the enclosed compound with the chapel that showed aristocrats the possibilities to build in grand style. The building complex must have been imposing to those who passed the manor, and the chapel was probably visible over the edge of the stockade to show the power of the new religion.

- To build the enclosed part of the manor in the eastern parts, the mounds nearby created a distance to other parts of the manor and to its visitors.

- The symmetry in which the buildings were planned showed some- 
thing that was not common in the landscape-something that probably was borrowed from the ring forts of the Danish king.

- In the manor the enclosed part with the hall building and the chapel was built to show power. The gables of these buildings together with the enclosure were probably high to demonstrate the importance of building vertically.

\section{THE DIFFICULTY OF ACCESSING GLORY AND DEMARCATION AGAINST OTHERS}

The enclosed area with the hall was placed in a prominent position in the eastern part of the manor. It was visible from all directions except for the east, where it was well embedded in the undulating landscape. If one approached the hall area from the west or the east, it was the enclosure with the large buildings with their gables raised to the sky that could be seen. They were the dominant features in the landscape.

The enclosure could be followed both in the west and the north of the manor. The boundaries to the south were constituted by the buildings placed beside the road. The enclosure was made of large posts, sparsely placed and linked by smaller posts that did not leave any traces. It is not possible to calculate the height of the stockade, but it was likely high enough that no one could see what was going on inside the enclosure. If the desire was to strengthen the impression of the enclosed part, it was no doubt important to create a sufficient barrier that prevented a view of the inside. The enclosure was probably intended not only as a defensive structure but also as an administrative border and possibly above all as a symbolic boundary.

\section{THE ADJACENT ANCESTORS}

In the eastern part of the enclosed area, approximately 20 metres east of the main hall, the remains of a stockade with a rampart were found. The remains consisted of parallel ditches and postholes and above these a layer of soil with fire-affected stones. This is probably the remains of a construction that enclosed the eastern part of the manor. The remains show similarities with a stockade at Guldborg, located in Langeland, Denmark. Guldborg was built in the early I 2 th century as a refuge against raiders. During the excavation of Guldborg a ditch with postholes, remindful of the one in Lockarp, was documented. The interpretation is that the posts served as a support for the stockade and the rampart on which the defenders were placed (Skaarup 2005:I I 2, 345). 
Enclosed farms from the Viking Age and Early Middle Ages are well known, and among the most famous are the royal estate of Lejre and the large farms at Tissø, Vorbasse and Lisbjerg (Hvass I98 I; Christensen I 99I; Jørgensen 2002; Jeppesen 2004; Christensen \& Andersen 2008).

To indicate that one entered a farm, or an area, controlled by the elite, certain elements were placed at its boundaries, its entrances and exits (Lundqvist 2000:2 I). This could be what the enclosure in Lockarp was, that is, a physical boundary that excluded those who were not invited to the hall. Frands Herschend has shown that the older halls were localized to the farm's outer borders, which is seen as an expression of the hall's function as a point of contact between the hall's owner and his visitors (Herschend I 998:20ff). It is possible that the stockade should be seen as a procession path for the aristocratic owner and the invited guests. They entered through a gate in the stockade and then were directly escorted into the hall. It is possible that the hall in Lockarp, despite being a few hundred years younger than the examples provided by Herschend, should be seen as a counterpoint between the hall area and the rest of the farm. The stockade could also have been a border against the old - the mounds and the old burial ground. The stockade can therefore also be seen as a symbolic boundary.

\section{FROM A MYTHICAL FORGE TO A HOLY CHAPEL}

In a dissertation Anna Hed Jakobsson discusses the connections that probably prevailed between specialized craftsmanship, central places and political authority during the Late Iron Age (Hed Jakobsson 2003). She gives an example that is of interest for the discussion of the manor in Lockarp. It concerns the spatial relation between forges and chapels on Iceland, and the changes that took place in connection with the Christianization of Iceland. On several farms private chapels were built around the year 1000. Archaeological excavations have shown that at least five out of nine investigated chapels were built on the same place as an older forge (Hed Jakobsson 2003:3 If; Söderberg 2005:222). One interpretation is that the change from a forge to a chapel was purely practical. The buildings had no symbolic value, and the change was merely a practical solution; it was easy to replace an existing building that possibly was used periodically. Another interpretation is that the building of the chapel was an expression of cult continuity, a symbolic action that expressed a contradiction between the smith, who represented the old pagan beliefs, and the Christian church that stood 
for the new beliefs. The old pagan knowledge possessed by the smith should be relinquished to the new Christian rulers and the priests of the church (Hed Jakobsson 2003:272).

\section{THE MYTHICAL FORGE}

In the forecourt of the manor, in a central position, there was a building measuring I I by 7 metres, which was interpreted as a workshop or forge (fig. 5). The building had slightly convex sidewalls. The gables differed from each other. The western gable was closed and consisted of six postholes, while the eastern gable was open. There were no traces of inner walls, but a clay floor in the western part makes it plausible that the building had two rooms. In the western room traces of a hearth were found, which could be the remains of the forge. In the same area the floor consisted of a large amount of charcoal, burnt silt and white sand that showed traces of fire. During the excavations the white sand was interpreted as sand used to put out the fire. The white sand was probably quartz sand that was used during forging. It was used partly to protect the iron from oxidising, and partly during the smithery when the blacksmith put together several layers of iron or steel, so-called welding; the sand improved the conglutination between the different layers (Grandin pers. comm.). In the floor layer in the western room, several tools were found that indicate handicraft in leather and wood. No tools associated with metalwork were found inside the building. However, burned and melted clay from the walls of the hearth, as well as parts of a smith's tong, billets and slag, were found in the vicinity of the forge indicating metalwork in the forecourt.

The location of the forge in the middle of the manor is interesting, since forges, because of the fire risk, were usually placed far away from the main buildings. That the forge was placed in the vicinity of the dwellings and the hall can be an indication that the location was important in the sense that the aristocrat wanted to control the forge in troubled times. A forge situated in the outskirts was an easy target. It can also be explained as that the smith became part of the organisation around the manor and thereby was further controlled by the aristocrat.

The social status of the craftsmen and the smiths has probably changed during history. Many times the archaeological material indicates that the smith was unfettered, at the same time as there are theories advocating that he was tied to the social elite that consisted of an aristocracy and their farms. Skilful smiths that could produce the status 
objects of the time, and the magnificent and powerful weapons, were obviously connected to central places and manors. Traces of specialized handicraft such as forging and casting are often visible in the environments of the elite (Ljungkvist 2006:90). Sources from the Continent mention that the most skilful craftsmen moved among the different Germanic courts and were even exchanged as gifts. There are different opinions whether these craftsmen were slaves or free men. Rich graves containing tools of smiths have been taken as a pretext that they were free men. At the same time the laws of the time mention that all craftsmen were not free men (Grandin \& Hjärtner-Holdar 2003:3 I3).

The concept of the smith is a strong generalization. A goldsmith in the service of an aristocrat cannot be compared to a blacksmith, but some common denominators appear to have existed. Some form of dependency, possibly with different levels of freedom, seems to have been common. At the same time blacksmiths have been regarded as persons with extraordinary powers (Hed Jakobsson 2003:I6I). The mere fact that the smithery was concentrated to the aristocracy, cult centres and trading places is a sign that the smith was an important person. The blacksmith was considered to be in communication with supernatural powers; forging was considered a skill linked to the supernatural (Burström I990). In the myths it was the dwarfs that controlled the metals gold, silver, copper and iron. The two dwarfs Sindre and Brock were considered to have forged the greatest possessions of the gods, such as the hair of Siv, Gollinburste (Gyllenborst) the boar and Skidbladner the ship, both of which belonged to Frey, as well as Oden's ring Draupner and his spear Gunger, and Thor's hammer Mjölner (Holtsmark I992:56).

The location of the forge in the enclosed part of the manor can be discussed on the basis of the concept deepest space. Deepest space describes a kind of spatial environment considered characteristic for sanctuaries and other buildings intended for religious practices (Hillier \& Hanson I984:I80f; Söderberg 2005:209). In this context the forge centrally placed in the forecourt was probably the least accessible building in the manor. It was probably only the owner and his household, his manager, and the persons he invited that had access to this area and the building. On the basis of that, the building in Lockarp should be seen as a forge (or workshop) with a cult function and not just as a regular forge.

Later research has shown that, in the Late Iron Age manors, there 
were small buildings in the vicinity of the hall buildings. Known as "side buildings", they are often found to the southwest of the hall and are relatively small rectangular buildings, sometimes surrounded by a fence or a stockade. Small side buildings have been excavated on sites such as Tissø and Lejre on Zealand, Järrestad in Scania, Borg in Östergötland, and possibly Sanda in Uppland (Christensen I99I; Lindeblad I996; Åqvist I 996; Andrén 2002; Jørgensen 2002; Söderberg 2005). The function of these buildings and the area surrounding them seems to have been ritual (Andrén 2002:3 I 5). It has been suggested that the buildings represent the concept of the Harg (cult centre) in the Nordic saga literature. In the side building in Järrestad there were several iron artefacts that indirectly link the building to metalwork, including an anvil and a smith's hammer. In addition an axe and a large iron ring were found. The location, close to the hall, strikes a discordant note in a possible interpretation of the building as a forge. Instead the finds and other observations indicate that the building should be associated with forging on a more symbolic level (Söderberg 2006:I 5 8ff). Also at Borg the building was used in some kind of cult. Just outside the building, two pits were excavated. These pits are probably the remains of two furnaces used in the cult, connected with forging (Hed Jakobsson 2003: I I 2). Just outside the forge in Lockarp were the remains of two furnaces, just like at Borg. In these furnaces, parts of blast nozzles were found which indicates some kind of metalwork. The resemblance to Borg is obvious. Is it possible that the two furnaces in Lockarp were used in the cult? In the discussion concerning the building in Borg, a quotation from the Poetic Edda is used (Lindeblad I 996:68). Maybe the same quotation can be used about the forge and the two furnaces in Lockarp.

"The Aesir met at Idavall,

They timbered tall cult centres and houses for sacrifice,

Forges were set up, and jewellery was hammered,

Forge tongs were forged and tools were crafted."
“Asarna möttes på Idavall, Timrade höga harg och blothus,

gjorde smideshärdar, hamrade smycken, smidde tänger, slöjdade redskap.” 


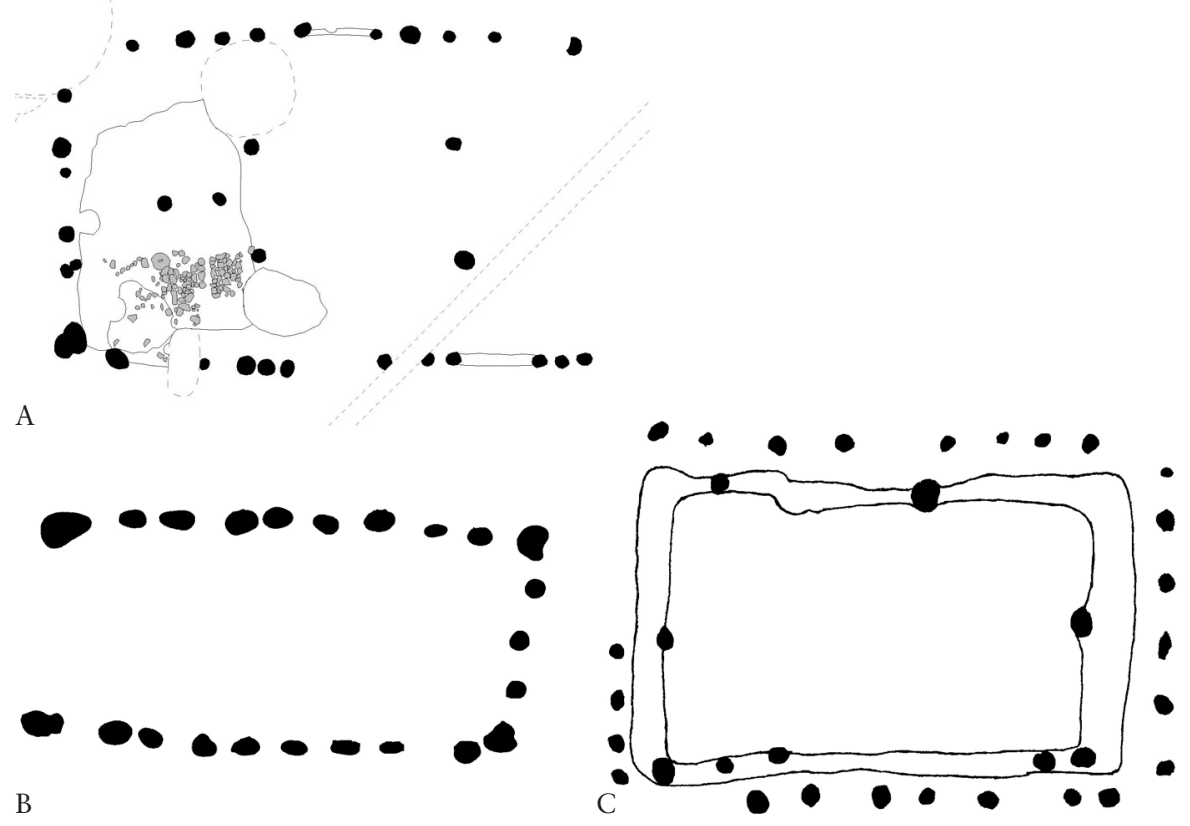

Figure 5. The forge at Lockarp compared with other interpreted forges. A. Lockarp, Scania. B. Ösarp, Halland. C. Fyrkat, Jutland. Note that the plans are rotated to show the similarities. Scale $\mathrm{I}: 200$.

Parallels to the forge in Lockarp have been found at, among other places, the large farm in Ösarp in Halland, Sweden, in the ring forts at Fyrkat on Jutland and Trelleborg on Zealand, and at the manorial farm at Vorbasse on Jutland, Denmark (Heimer 2009). Ösarp is interpreted as a large farm, possibly a manor, from the Late Iron Age (Viking \& Fors I 995). Ösarp was, like Lockarp, located just a few kilometres from a market place, Köpinge (Bjuggner \& Rosengren I999:94). At Ösarp a small building was excavated and interpreted as a forge (Carlie I999:I36). The forge was placed approximately I 5 metres from a dwelling house of "Trelleborg-type", just like in Lockarp. At Fyrkat there was a small building, Io by 5 metres, situated in the forecourt of house group 2. Inside the building were parts of crucibles indicating gold, silver and bronze casting. A possible hearth was also excavated. The finds can be seen as indirect evidence that the building had been used as a workshop (Roesdahl I977:I 53 ff.). In addition, two smaller buildings with similar location were excavated in Fyrkat, but their function is unclear (Roesdahl I977:I 59, fig 223). The interpretation of the building in Trelleborg is uncertain, but it has been suggested that 
it was used as a house for a chieftain. However, there were no finds in the building to support this assumption (Wulff Andersen I 998:I9). The similarities to the houses at Fyrkat, and the fact that the ring forts were such uniform creations, makes it more likely, in my view, that the building in Trelleborg as well as at Fyrkat was used as a workshop of some kind. In the building at Vorbasse, which lay approximately 33 metres south-east of the main farm building - a "Trelleborg-type" house - two phases could be observed. In the early phase the building was used as a shed for domestic animals, and in the later phase the building was changed into a forge (Hvass I981: 58 ff).

\section{THE HOLY CHAPEL}

Sometime during the second half of the I I th century the forge or workshop at Lockarp was replaced with a new building measuring I 5 by 7 metres. This building was constructed in the same way as the large hall building, with outer rows of supporting posts resembling a "Trelleborgtype" house (fig. 6A). The building consisted of at least two rooms, possibly three. The western room was approximately Io by 4.5 metres, and part of it was three-aisled with roof-supporting posts at the far west, while the roof in the eastern part was supported by the walls. In the south long wall there was an opening in the wall trench that indicated a door. In the eastern part of the building, postholes were found that formed a small expansion in the gable, their breadth and placement corresponding well to the placement of the roof truss in the western room. The eastern room was approximately 4 by 2.5 metres. The eastwest orientation of the building together with the east expansion, which is remindful of a chancel, suggests that the building served as a chapel.

Early churches have foremost been identified by the presence of graves and their locations under existing stone churches (Anglert I 995:67f; Roesdahl 2004:20Iff). But there is one example of an early church in Scania that lacked graves and that was not replaced with a younger church. It was found and excavated in a profane farm environment just 40 kilometres north of Lockarp, in Särslöv (fig. 6B). It was centrally placed in the farm and consisted of a robust three-aisled construction. Like the building in Lockarp, the eastern part of the Särslöv building had roof-supporting posts, forming a three-aisled room. In the middle of the building, the roof was supported by the walls. In both long walls there were entrances, of which the southern one had salient door posts. In the eastern part of the building, postholes were found 
that formed a small space in the gable, whose breadth and placement, just like the building in Lockarp, corresponded well to the placement of the roof truss in the western room. On the basis of the central location of the building, its unique and robust construction and the ground plan, with a presumed nave in the western part and a chancel in the east, the building is interpreted as a chapel (Kriig \& Thomasson 2000:20; Thomasson 2005:II3; Anglert 2006:83f, 99).

In an attempt to locate chapels in the Viking Age settlement at Omgård, Jutland, the archaeologist Leif Christian Nielsen set up the following criteria (Nielsen I991:258):

- The building ground plan should correspond to the Romanesque stone churches with a nave and a chancel.

- The building should have a relation to an older, presumed, pagan cult complex.

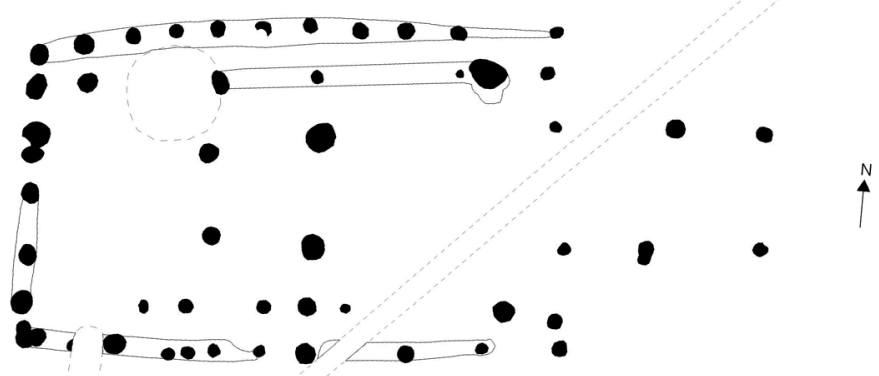

A

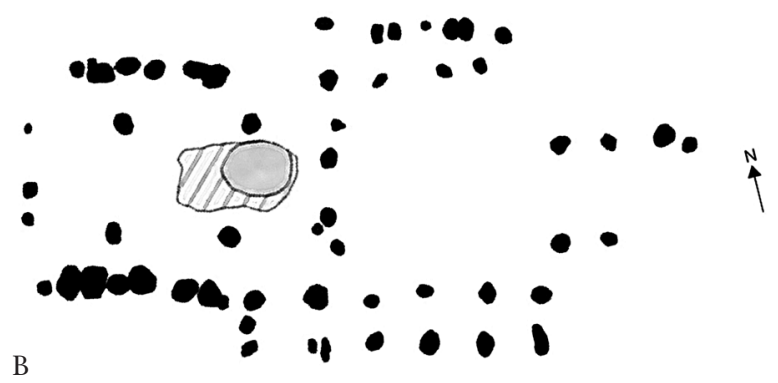

Figure 6. Example of an early Christian chapel from Scania compared with the chapel in Lockarp. A. Lockarp, Scania, middle of I Ith century. B. Särslöv, Scania, end of I Ith century (after Kriig $\&$ Thomasson 2000:20, fig. I7; Heimer et al. 2006:80, fig. 64). Note that the plans are rotated to show the similarities. Scale I:200. 
- The building should be placed centrally on a farm.

- The building should be on the property of a lord or magnate.

- A direct connection through a gate to the main building of the farm.

A majority of these criteria can be applied to the building in Lockarp:

- The ground plan consisted of a presumed nave with a chancel in the east.

- The spatial connection with an older forge that could have served in the pagan cult.

- The building was centrally placed in the forecourt, which should be regarded as both the architectural and spatial centre of the manor.

- The building is placed on a manorial farm and was the property of a lord or magnate.

The direct spatial link between the forge and the chapel, and the fact that both these buildings constituted the architectural and spatial centre of the manor, shows that they had a central function within the manor. The chapel was a direct link to the social elite. An important part of the Christianization of Scandinavia was the aristocracy that built private churches on their farms (Sanmark 2004:83 ff). Something that speaks against the interpretation that the building served as a chapel is the lack of graves. Leif Christian Nielsen meant, however, that it was not necessary to have a burial place in connection with the churches placed on manorial farms. The Christian cemetery could have been located someplace else before it was moved to the church, or perhaps the church was moved to the cemetery (Nielsen I991:260).

No Viking Age graves have been found in Lockarp. In pre-Christian time the nobility in Lockarp probably buried their dead in the burial ground at Ljungbacka, just one kilometre north of Lockarp (fig. 7). During excavation of the burial ground, several graves dated to the Late Iron Age were examined; two of them have been identified as warrior graves, with equipment such as a battle axe and spurs (Samuelsson 2003:9If). Maybe these graves are the reminiscence of the aristocracy in Lockarp. Christian Adamsen has presented a hypothesis when it comes to connecting a burial ground to a settlement. In his view, one could search for Viking Age burial grounds on the other side of a stream, opposite the settlement (Adamsen 2004:20ff). He gives several examples from southern Scandinavia and mentions that it was 


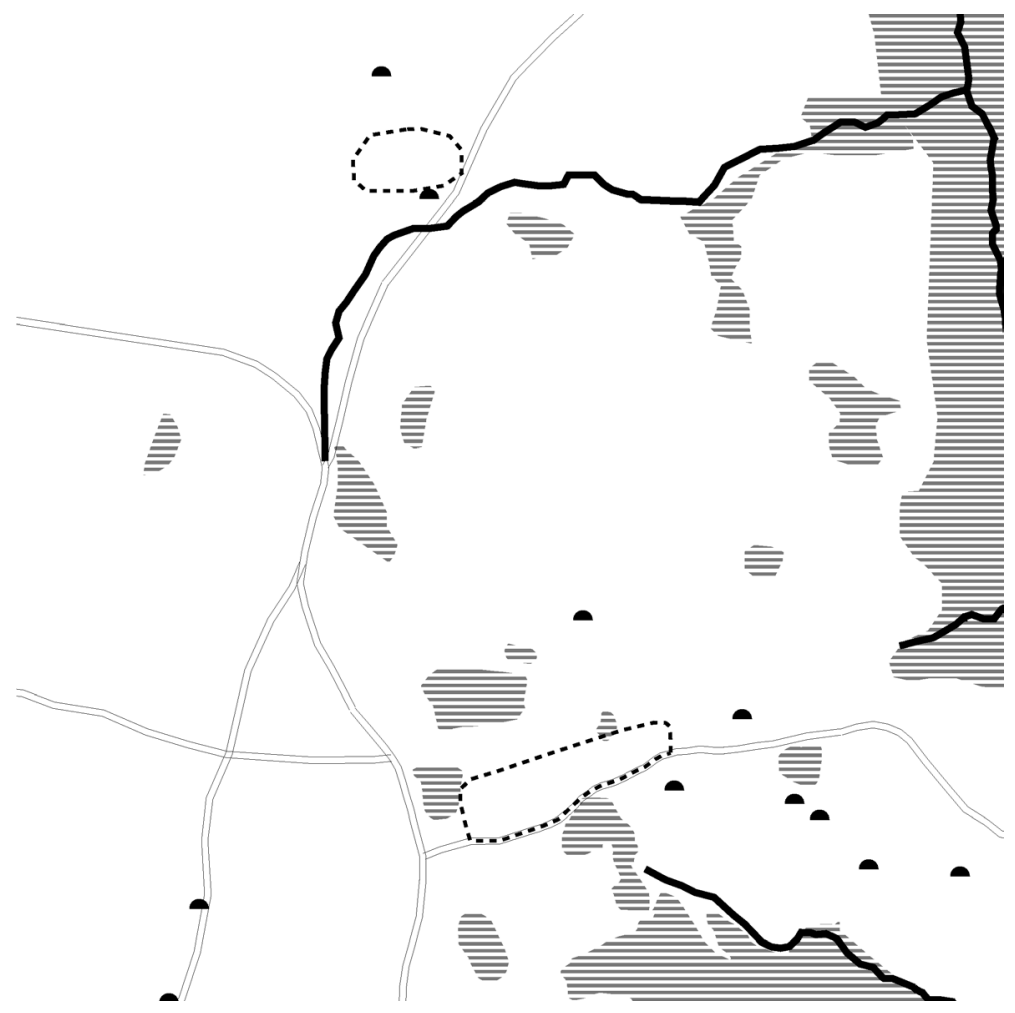

Figure 7. The map shows the boundaries (dashed) of the manor in the south and the Ljungbacka burial ground in the north. The boundaries of the burial grounds are approximate. Semicircles mark burial mounds. The roads (hollow lines), the stream and Risebergabäcken (solid lines), meadows and wetlands (hatched) are digitalized from historical maps. Scale I:20 000.

important to cross water, perhaps via a bridge or a forge, Gjallarbro, to the underworld when burying the dead. On a Scanian survey map from I 8 I 2-I 820 (Sw. Skänska rekognoceringskartan) a watercourse is visible just south of the Ljungbacka burial ground, about one kilometre north of the manor in Lockarp (fig. 7). Is this the stream that can be interpreted as the river of the dead, the stream one had to cross via Gjallarbro, on the way to the burial ground?

If the aristocracy in Lockarp did not bury their dead at Ljungbacka, one must seek their burial ground in another place. In that case one should, perhaps, look for their graves on the other side of Risebergabäcken and the ford called Galljevad, in a burial ground that has not yet been discovered. The ford Galljevad is marked on an I 8th-century map as the name of the nearby field that is called Galljevadsåkra. The 
name is generally interpreted as the ford on the way to the Gallows (Sw. Galje), in Oxie (Persson 2008:9). Boldly put, maybe this should be reinterpreted as the Gjallarbro, the bridge to the underworld.

When the nobility in Lockarp became Christian, they probably buried their dead in a new cemetery. There are no known graves from that time in Lockarp and therefore one has to search elsewhere. The present church was built in $1885-86$, on the same site as a medieval church. The medieval history of the church is for the most part still unknown. The church is, however, known in the mid-I 7 th century as a rather small parish church without a tower or apse (Kling pers. comm.). Since the nobility in Lockarp at that time was probably closely connected to the king, it is likely that we would find their graves in a cemetery at the new Christian centre of Lund. In his study on the number of dead buried in the oldest cemetery in Lund, Peter Carelli found that the number of burials was about 7-9 times higher than in the slightly younger cemeteries in Lund, and up to 20 times higher than in, for example, the rural cemetery of Tirup on eastern Jutland. He suggests that the cemetery in Lund formed an early Christian necropolis for Scania (Carelli 2004:254ff). This might explain the lack of graves in Lockarp.

\section{A SECOND CHAPEL}

In connection with the excavations, traces of several, large, stone impressions were documented, in younger layers, above the chapel (fig. 8). The building measured I 2 by 6.5 metres and is probably a rebuilding of the older chapel. It had the typical shape of a chapel with a nave and was almost of the same proportions as the older chapel. There were no traces of a chancel, but from a source-critical perspective it can be noted that several layers of clay were documented in the area where the chancel could have been located. These layers were interpreted as belonging to other buildings, dated to about AD I I 5O-I 250 . It is therefore possible that one could search for the chancel in these layers. The building had the same east-west orientation as the old chapel, with a slight shift. The size of stone impressions implies that the construction was large.

To assume that the building is a second chapel is perhaps bold, but the size of the building and its location promote the interpretation of a chapel. If that was the case, that there was a second chapel, built with stone joists, then this farm was an aristocratic environment well in to the High Middle Ages. The connection between medieval chapels or 
churches and manorial farms is well known in medieval Scandinavia. Sometimes these chapels and churches were developed into parish churches (Wienberg 1993:177) and in other cases they disappeared. These manorial chapels probably lacked burial rights, and therefore the absence of graves or traces of a cemetery is not remarkable (Hansson I999:50f).

Within the same area as the chapels, several objects of religious character were found. Just north of the chapel there was a find of a small, folded, lead foil (fig. 9A). On both sides there are runes or rune-like signs. They do not provide a cohesive text, which is more the rule than an exception when it comes to inscribed objects such as this. The foil is not older than the I 2 th century and could well be younger since lead foil of this kind occurs during the entire Middle Ages (Snædal 2007). Similar foils, folded or convoluted, have been found earlier and are generally interpreted as amulets with a religious meaning (Gustavson \& Snædal Brink I980:229ff). West of the chapel a crucifix was found (fig. $9 \mathrm{~B}$ ). The design is typical for medieval crosses and crucifixes and can probably be dated to the I 2 th or I 3 th century. The crucifix shows Christ in "Majestas Domini" surrounded by a mandorla (a gloriole around his silhouette). Majestas Domini portrays Christ raising his hand, the image of the Lord in Majesty. When he stands with his right hand raised and a book in his left hand, it is to show the way to Saint Peter (Söderlind 200I:6f). The extension of the lower part suggests that the crucifix had been fastened to another object (Heimer et al. 2006:137). The upper part of the crucifix is flattened, which indicates some damage to the crucifix. It is possible that the crucifix originated from the later chapel.

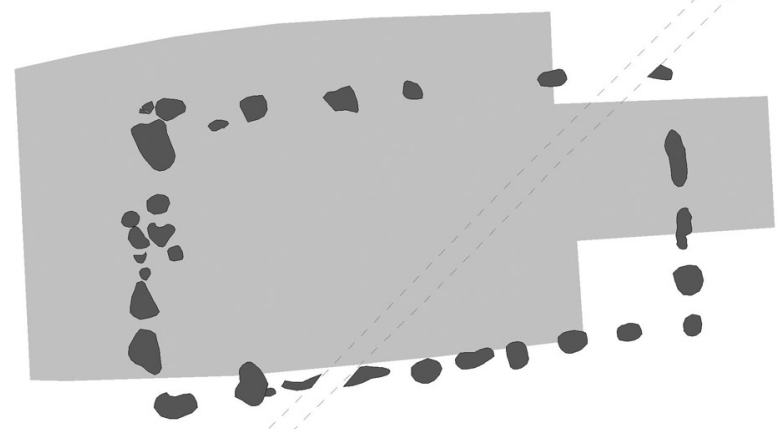

Figure 8. Dark grey shows the stone impressions from a younger chapel. Light grey shows the position of the older chapel. Scale I:200. 
A

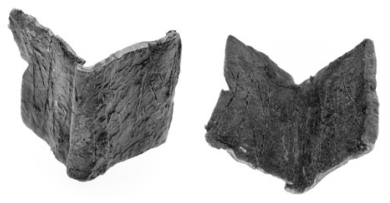

B

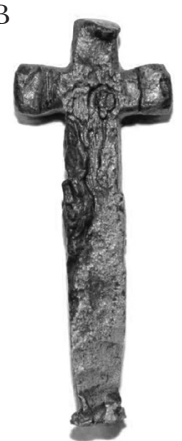

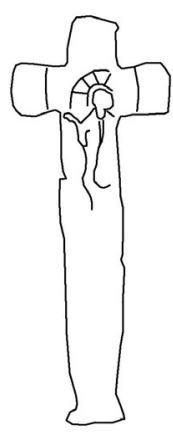

C

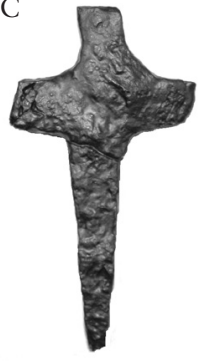

Figure 9.

A. Lead foil. Scale I: I Photo: Bengt A. Lundberg. Riksantikvarieämbetet, Stockholm.

B. Crucifix with interpreted embossments. Scale I: r. Photo and drawing: Olle Heimer.

C. Iron cross from the preliminary investigation. Scale r:2. Photo: Olle Heimer.

During the preliminary investigations in Lockarp, another cross was found (fig. 9 C). It is an iron cross measuring approximately 7 by 3.5 centimetres. The cross was found in a posthole in the outskirts of the manor and could not be linked to any building or any other structure (Heimer 2002:96). The interpretation of the cross is uncertain, but it could be a preparatory work made in a forge in Lockarp.

\section{CONCLUSION}

This journey from paganism to Christianity in Lockarp is an attempt to understand the buildings that stood in the courtyard at the manorial farm in Lockarp, and what they represented. To sum up, one can say that the location is of great importance and can be discussed on the basis of the concept deepest space. Deepest space describes a kind of spatial environment considered characteristic for sanctuaries and other buildings for religious practices. Primary in this context is the forge, an important building in pagan beliefs. It was the building that could represent the cult centre (Harg) in the Nordic saga literature. The location of this building, in the middle of the manor, can be an indication that it was important for the aristocrat to control the cult. It can also show that it was important for the aristocrat to control the forge in troubled times. Another explanation is that the blacksmith became part of the organisation around the manor and in that way was further controlled by the aristocrat. Later on this building was replaced with a new, more impressive building. The new building was built in the same 
way as the large hall, with outer rows of supporting posts resembling a "Trelleborg-type" house. The east-west orientation of the building and the east expansion, which is remindful of a chancel, imply that the building should be interpreted as a chapel. The new religion, Christianity, had arrived. Later on this chapel was replaced with a new chapel that was almost the same size but built on stone joists.

Olle Heimer, Københavns Museum, Vesterbrogade 59, I620 København V, Denmark

\section{References}

Adamsen, C. 2004. På den anden side. SKALK nr. 5. Pp. 20-28.

Andrén, A. 2002. Platsernas betydelse. Norrön ritual och kultplatskontinuitet. In: Jennbert, K., Andrén A. \& Raudvere, C. (Eds). Plats och praxis. Studier av nordisk förkristen ritual. Vägar till Midgård 2. Pp. 299-342. Lund: Nordic Academic Press.

Anglert, M. I995. Kyrkor och herravälde. Från kristnande till sockenbildning i Skåne. Lund Studies in Medieval Archaeology I6. Stockholm: Almqvist \& Wiksell International.

Anglert, M. 2006. Vidinge, torpnamn och kristen gårdskult. In: Larsson S. (Eds). Centraliteter. Människor, strategier och landskap. Pp. 77-Ioo. Lund: Riksantikvarieämbetets förlag.

Bjuggner, L \& Rosengren, E. I 999. Likt eller olikt - bebyggelse på den sydhalländska landsbygden under tidig medeltid. In: Artelius, T., Englund, E. \& Ersgård, L. (Eds). Kring västsvenska hus - boendets organisation och symbolik i förhistorisk och historisk tid. Gotarc Serie C. Arkeologiska skrifter No 22. Pp. 87-97. Göteborg: Institutionen för arkeologi, Göteborgs universitet.

Björhem, B., Jönsson, L \& Lövgren, K. 2008. Arkeologisk slutundersökning 2007. Lockarps bytomt-exploatering på fastigheten Lockarp 3 I:I med anledning av lednings-, brunns- och arbetsvägar inom Citytunnelprojektet. Lockarps socken i Malmö stad, Skåne län. Enheten för Arkeologi. Rapport 2008:054. Malmö: Malmö Kulturmiljö.

Burström, M. I990. Järnframställning och gravritual. En strukturalistisk tolkning av järnslagg i vikingatida gravar i Gästrikland. Fornvännen I990/4. Pp. 26 I-27 I

Carelli, P. 2004. Lunds äldsta kyrkogård och förekomsten av ett senvikingatida danskt parochialsystem. In: Lund, N. (Eds). Kristendommen i Danmark før I050. Et symposium i Roskilde den 5-7 februar 2003. Pp. 253-258. Roskilde: Roskilde museums forlag.

Carlie, L. I999. Bebyggelsens mångfald. En studie av södra Hallands järnåldersgårdar baserad på arkeologiska och historiska källor. Acta Archaeologica Lundensia. Series in $8^{\circ}$. No. 29. Lund: Lunds universitet.

Christensen, P. M. \& Andersen W. S. 2008. Kongeligt? SKALK nr I. Pp. 3-Io. 
Christensen, T. I99 I. Lejre beyond Legend - The Archaeological Evidence. Journal of Danish Archaeology. Vol. Io. Pp. I63-I 85.

Ethelberg, P. 2003. Gården og landsbyen i jernalder og vikingetid ( 500 f.Kr. - rooo e.Kr.). In: Ethelberg, P., Hardt, N., Poulsen, B. \& Sørensen, A. B. (Eds). Det Sønderjyske Landbrugs Historie. Jernalder, vikingetid og middelalder. Skrifter udgivet af Historisk Samfund for Sønderjylland Nr. 82. Pp. I 23-373. Haderslev: Historisk Samfund for Sønderjylland.

Grandin, L \& Hjärtner-Holdar, E. 2003. Metallhantverk vid storgården. Ett arkeometallurgiskt perspektiv. In: Söderberg, B. (Ed). Järrestad. Huvudgård $i$ centralbygd. Arkeologiska Undersökningar Skrifter No 5 I. Pp. 309-340. Malmö: Riksantikvarieämbetet.

Gustavson, H \& Snædal Brink, T. I980. Runfynd 1979. Fornvännen I980/4. Pp. 229-239.

Hansson, M. I999. Agundaborg och Källarholmen - två medeltida "borgar" i Småland: rapport över arkeologiska undersökningar av Agundaborg, RÄ̈39, Agunnaryd socken och Källarbolmen, RÄ̈ 3 I, Ryssby socken, Ljungby kommun, Kronobergs län. Report Series No. 68. Department of Archaeology. Lund: Lunds universitet.

Hed Jakobsson, A. 2003. Smältdeglars härskare och Jerusalems tillskyndare. Berättelser om vikingatid och tidig medeltid. Stockholm Studies in Archaeology 25. Stockholm: Stockholms universitet

Heimer, O. 2002. Lockarps bytomt (delområde 8). Rapport över arkeologiska förundersökningar. In: Lindhé, E., Sarnäs, P. \& Steineke, M. (Eds). Citytunnelprojektet. Rapport nr 38. Pp. 9I-99. Malmö: Malmö Kulturmiljö.

Heimer, O. 2009. Att bygga aristokrati - spår efter en aristokratisk livsstil på det medeltida godset i Lockarp. In: Hadevik, C. \& Steineke, M. (Eds). Tematisk rapportering av Citytunnelprojektet. Rapport nr 48. Pp. 33 I-386. Malmö: Malmö Museer, Arkeologienheten.

Heimer, O., Ifverson, P. \& Persson, J. 2006. Citytunnelprojektet Lockarps bytomt - delområde 8. Rapport över arkeologisk slutundersökning. Rapport nr 45 . Malmö: Malmö Kulturmiljö.

Heimer, O \& Persson, J. 2007. Arkeologisk förundersökning. Lockarps bytomt. Lockarp 3 I: I. Lockarps socken i Malmö stad, Skäne län. Enheten för Arkeologi Rapport 2007:008. Malmö: Malmö Kulturmiljö.

Herschend, F. 1998. The Idea of the Good in Late Iron Age Society. Occasional Papers in Archaeology I 5. Department of Archaeology and Ancient History. Uppsala: Uppsala universitet.

Hillier, B \& Hanson, J. I984. The Social Logic of Space. Cambridge: Cambridge University Press.

Holtsmark, A. I992. Fornnordisk mytologi. Tro och myter under vikingatiden. Lund: Studentlitteratur.

Hvass, S. I98 I. Vejle: Vorbasse. The Viking-age Settlement at Vorbasse, Central Jutland. Acta Archaeologica Vol. 50, I979. Pp. I37-I72.

Jeppesen, J. 2004. Stormansgården ved Lisbjerg kirke. Nye undersøgelser. KUML 2004. Årbog for Jysk Arkæologiskt Selskab. Pp. I6I-I 80.

Jørgensen, L. 2002. Kongsgård - kultsted - marked. Overvejelser omkring Tissøkomplexets struktur og funktion. In: Jennbert, K., Andrén A. \& Raudvere, C. (Eds). Plats och praxis - studier av nordisk förkristen ritual. Vägar till Midgård 2. Pp. 2I 5-245. Lund: Nordic Academic Press.

Kriig, S \& Thomasson, J. 2000. En gard frän sen vikingatid-tidig medeltid. Från stenålder till medeltid i Särslöv. Skåne Dagstorps sn Särslöv 2:I, VKB SU 22. UV Syd Rapport I999:I06. Lund: Riksantikvarieämbetet. 
Lindeblad, K. I996. Borgs socken - förändringar i tid och rum 200-I 200 e kr. In: Lundqvist, L., Lindeblad, K., Nielsen, A-L \& Ersgård, L. (Eds). Slöinge och Borg. Stormansgårdar i öst och väst. Pp. 53-77. Arkeologiska Undersökningar. Skrifter nr I 8. Linköping: Riksantikvarieämbetet.

Ljungkvist, J. 2006. En hiar atti rikR. Om elit, struktur och ekonomi kring Uppsala och Mälaren under yngre järnålder. Aun 34. Institutionen för arkeologi och antik historia, Uppsala: Uppsala universitet.

Lundqvist, L. 2000. Järnålderns centra-exempel från Halland och Västergötland. GOTARC Serie C. Arkeologiska Skrifter No. 35. Göteborg: Göteborgs universitet.

Nielsen, L C. I99 I. Hedenskab og kristendom. Religionsskiftet afspejlet i vikingetidens grave. In: Mortensen, P \& Rasmussen, B. M. (Eds). Fra Stamme til Stat $i$ Danmark 2. Høvdingesamfund og Kongemakt. Jysk Arkæologisk Selskabs Skrifter XXII:2. Pp. 245-267. Aarhus: Aarhus Universitetsforlag.

Nørlund, P. I948. Trelleborg. Nordiske fortidsminder. 4:I. København: Gyldendal.

Persson, L. 2008. Kulturgeografisk utredning vid Lockarps bytomt. En studie av äldre lantmäterikartor för ett område inom och kring ett arkeologiskt undersökningsområde. Fastigheten Lockarp 3I:I/ Lockarps socken i Malmö stad, Skàne län. Enheten för Kulturmiljövård. Rapport 2007:026. Malmö: Malmö Kulturmiljö.

Roesdahl, E. I977. Fyrkat. En jysk vikingeborg. II. Oldsagerne og gravpladsen. Nordiske fortidsminder 3 . København.

Roesdahl, E. I980. Danmarks vikingetid. København: Gyldendal.

Roesdahl, E. 2004. Hvornår blev kirkerne bygget? In: Lund, N. (Eds). Kristendommen i Danmark for I050. Et symposium i Roskilde den 5-7 februar 2003. Pp. 20I-206. Roskilde: Roskilde museums forlag.

Samuelsson, B-Å. 2003. Ljungbacka - a Late Iron Age Cemetery in South-West Scania. Lund Archaeological Review (LAR). 200I. Pp. 89-I08. Department of Archaeology. Lund: Lunds universitet.

Sanmark, A. 2004. Power and Conversion - a Comperative Study of Christianization in Scandinavia. Occasional Papers in Archaeology 34. Department of Archaeology and Ancient History. Uppsala: Uppsala Universitet.

Skaarup, J. 2005. Øhavets middelalderlige borge og voldsteder. Meddelelser fra Langelands Museum. Rudkøbing: Langelands Museum.

Snædal, T. 2007. "Blybleck från Lockarp”. Unpublished report. Diarienummer 322I309-2007. Runverket. Stockholm: Riksantikvarieämbetet.

Söderberg, B. 2005 . Aristokratiskt rum och gränsöverskridande. Arkeologiska Undersökningar Skrifter No 62. Stockholm: Riksantikvarieämbetet.

Söderberg, B. 2006. Några perspektiv på kulten i en härskarmiljö - Järrestad under yngre järnålder. In: Anglert, M., Artursson, M \& Svanberg, F. (Eds). Kulthus och dödshus. Det ritualiserade rummets teori och praktik. Pp. I 53-I66. Stockholm: Riksantikvarieämbetets förlag.

Söderlind, A. 200 I. Att se det osynliga. En teknisk och ikonografisk analys av tre medeltida hängen från Sigtuna och Uppsala. Unpublished MA thesis in Archaeological Science. Stockholm: Stockholms universitet.

Thiis-Evensen, T. I998. Arkitekturens maktgrammatik. In: Kullberg Christophersen, C. (Ed.). Maktens korridorer. Arkitektur som politikk. Pp 5-I4. Oslo: Norsk Form.

Thomasson, J. 2005. Bybildningen och bönderna. In: Mogren, M.(Ed.). Skånska spår - arkeologi längs Västkustbanan. Byarnas bönder. Medeltida sambällsförändring $i$ Västskåne. Pp.44-I39. Avdelningen för arkeologiska undersökningar UV Syd. Stockholm: Riksantikvarieämbetet. 
Viking, U \& Fors, T. I 995. Ösarp. Vikingatida och tidigmedeltida agrarbebyggelse i södra Halland. RAÄ I 97, Ösarp I:2 I, 2: I 5, Laholms lfs, Halland. Arkeologisk undersökning I993. Unpublished report (Arkivrapport). Uppdragsverksamheten. Halmstad: Stiftelsen Hallands Länsmuseer.

Wienberg, J. I993. Den gotiske labyrint. Middelalderen og kirkerne i Danmark. Lund Studies in Medieval Archaeology I I. Stockholm.

Wranning, P. I999. Sydhalländska Trelleborgshus - lokala variationer av ett senvikingatida byggnadsskick. In: Artelius, T., Englund, E. \& Ersgård, L. (Eds). Kring västsvenska hus - boendets organisation och symbolik i förhistorisk och historisk tid. Gotarc Serie C. Arkeologiska skrifter No 22. Pp. 37-50. Göteborg: Institutionen för arkeologi, Göteborgs universitet.

Wulff Andersen, S. I998. Vikingeborgen Trelleborg. Slagelse: Museet ved Trelleborg. Åqvist, C. I996. Hall och harg - det rituella rummet. In: Engdahl, K. \& Kaliff, A. (Eds). Religion frän stenåldern till medeltid. Artiklar baserade på Religionsarkeologiska nätverksgruppens konferens på Lövstabruk den I-3 december I995. Pp. I05-I 20. Arkeologiska Undersökningar. Skrifter nr. I9. Linköping: Riksantikvarieämbetet.

\section{Personal communication}

Grandin, L. pers. comm. Geoarkeologiskt Laboratorium (GAL), UV Mitt, Riksantikvarieämbetet. Email from 2009-I I-26.

Kling, J. pers. comm. Kyrkoantikvarie, Kulturarvsenheten, Malmö museer. Email from 2009-IO-I 6 . 


\section{THE ART OF VALUATING A HERITAGE:}

\section{From a Swedish management perspective with past and present examples}

Ola W. Jensen

\begin{abstract}
To identify what ought to be protected and why is one of the most important missions of the heritage management. Issues related to values and the act of assessing are, however, seldom scrutinized on a deeper level. The aim of this article is to give a short history of the valuation of the heritage up to the present from a Swedish perspective. Additional aims are to reveal some current and historical trends in order to illustrate the connection between past and present valuation systems, to analyze various issues that have contributed to the current pluralistic approach, and to investigate which theories of values affect our assessments today.
\end{abstract}

Key words: heritage values, value theories, heritage management, history of heritage, history of heritage values, heritage studies, governmentality studies

\section{INTRODUCTION}

Within cultural heritage management we routinely conjure up different values on a daily basis to motivate the preservation of artifacts, monuments, buildings and entire cultural landscapes. Indeed, as archaeologists and antiquarians we are trained and commissioned to select articles of value out of a vast potential heritage. But nothing is static and a closer inspection reveals that the assessment of the heritage has its own shifting history. Different times have emphasized different categories and definitions of values due to changing attitudes as to who has the right to define what should be preserved, but also who the selected 
heritage is supposed to represent and, ultimately, why this is important.

But what is a value and what exactly do we mean by a valuable heritage? Generally questions such as these are seldom articulated and even less so evaluated within a heritage management context (see also Biörnstad I990:4; Almevik \& Fridén I995:92; Mathers et al. (Eds.) 2005; Unnerbäck 2000:30). At times there are exceptions, however, and they tend to coincide with upheaval and major societal (political, ideological and economical) and intellectual transformations. Such a situation has been observed in recent decades: once again the assessment itself has been highlighted both internationally (for recent examples, see Mathers et al. (Eds.) 2005; Smith 2006; Smith et al. (Eds.) 20I0; West (Ed.) 20I0; Harrison (Ed.) 2010) and from a Swedish perspective, which in turn has revealed pluralistic and contradictory opinions on how to define heritage values.

As will become apparent, several interconnected circumstances have given rise to the present situation. In this paper I will study these factors and analyze different attitudes towards heritage values that are expressed today from a Swedish perspective. Predictably, this situation has not appeared out of nowhere, and in order to scrutinize the current state of affairs it is necessary to thoroughly examine how things were in the past. That is my second intention with this text. A third matter that I will address is the various essential theories of values expressed within the heritage context today. Rather surprisingly, this subject is almost notoriously overlooked in the literature covering the assessment of the heritage; this is especially surprising considering that theories of values form the very foundation of our value systems and ideologies of preservation. The point at issue in this text is in what way various theories fundamentally affect our attitudes towards the heritage.

\section{CULTURAL HISTORICAL VALUES}

From a management perspective the heritage is ascribed different categories of values which in turn are ordered in different typologies, and at present several typologies or systems of values expressing more or less different features coexist (e.g. Mason 2008; Lindblad 2009). A joint concept frequently referred to in a Swedish context since the early 20 th century is "cultural historical values" (Sw. kulturhistoriska värden). Its definition has varied and mutated over time and at present it is commonly divided into three main categories: knowledge value, emotive (or experiential) value, and use value (Sw. kunskaps-, upplevelse- and 
brukarvärde, see Kulturmiliön som resurs 2007). In addition each of these categories has several sub-values with their own histories which I will summarize in the following sections.

As the term suggests, emotive value is commonly associated with various visual, emotional and social qualities that are believed to foster a sense of existential and social support in life (see also Beckman I993; Unnerbäck 2000). Among its sub-values we find aesthetic, artistic, symbolic, social, and above all identity aspects. A sub-value with an old aura applied in this context is reverence value (Sw.pietetsvärde) which refers to the veneration for and the sense of connection and kinship to previous generations. Such an attitude towards the heritage was emphasized already in the I 6 th and 17 th centuries and was founded on the Christian ethics fostering a sense of obligation to remember earlier generations by preserving and caring for their remnants. Let me present some examples.

In the mid-I6th century the Catholic archbishop Olaus Magnus claimed that it was necessary to preserve ancient monuments since they had originally been erected with the purpose of immortalizing and hence transmitting the memory of the deceased or an important event (Olaus Magnus 200I:64, 67-68, I26). This ethical value of memorial was later articulated and emphasized in the motivations of the first Ancient Monument Act of I666, as seen in quotations such as, "for the honor of the country and the memorial of our forefathers" and "for our forefathers and our country's immortal fame" (Kongl: Mayst:tz Placat och Påbudh om Gamble Monumenter och Antiquiteter, I666 and in Schück I932:359, 36I, my translation). In line with this attitude several concepts referring to the memory of older generations ( $\mathrm{Sw}$. minnesmärke, fornminne, kulturminne, my italics) were coined in the I 8th and I9th centuries, and as late as in the Ancient Monument Act of 1942 it was explicitly proclaimed that the aim was to "preserve the memory of the native country's early inhabitants" (SFS I942:350, my translation; see also Jensen I998).

A further aspect of the Christian ethic was the condemnation of any disturbance of the dead, including the ancient heathen forefathers. With this in mind it becomes logical that such an approach was expressed in the motivation of the legislation of I 666. In one of its drafts it was regretted that all too few paid their respects to their ancestors and that it was of immense importance to leave "the graves and the bones of our forefathers alone and preserved" ("Ett kort utkast ..." Konceptböcker 
I666-I673, B I:I, Äa I, ATA, my translation). Olaus Magnus, for his part, strongly condemned any intrusions into graves, especially if the purpose was simple greed -i.e. one of the deadly sins - and the search for hidden treasures (Olaus Magnus 2001:759). Expressing a similar attitude, a royal decree of the $\mathrm{I} 63$ os proclaimed that it was forbidden to search for treasures in the mounds at Old Uppsala in Uppland; the reason given was that it was not permissible to disturb the dead (see Jensen 2004). Interestingly enough the same reverence even affected the practice of excavation. In the I66os the holder of the Chair of Antiquarian Studies, Olof Verelius, conducted an extensive exploration of a mound in Ulleråker, Uppland (Jensen 2004). The mound was excavated from the side and not from the top which was the most common strategy at the time. Verelius motivated his approach by stating that it was less laborious but also that he simply did not want to disturb the souls of the dead.

Looking forward in time, the condemnation of encroachments into ancient graves - what we could call an ethical value of grave protection - was later reproduced within the heritage management well into the I9th century. In I 828 a new Ancient Monument Act was ordained which forbade the excavation of mounds without permission from the state authority in charge. In a draft of the legislation this authorization was motivated by the necessity that "our ancestors' remains as far as possible can rest in peace in the free Swedish soil" ("PM den 26 november I 827 ", Vol. 6. GF\&JAA, ATA, my translation). And regarding the then newly ordained Ancient Monument Act of I 867, the archaeologist Herman Hofberg wrote in the same spirit that it was important "to let the dead rest in peace" (Hofberg I 87 I:8f, my translation).

\section{IDENTITY VALUE AND THE SUBJECT OF OWNERSHIP}

By all accounts the most important value appealed to in the motivation for preservation - today often associated with the earlier described category of emotive value - has by tradition been the vital task of the heritage in the construction of collective identities. The previous I 7 thcentury quotations referring to the honoring of Sweden - "for the honor of the country" and for the "country's immortal fame" - are early illustrative examples of the patriotism which has long been associated with heritage management and the care of materialized histories. In those days the patriotism did not concern everyone; in principle it was limited to the learned and to the aristocratic part of society. The leg- 
islation from 1666 was also restricted in the sense that it mainly referred to monuments located on state property. Indeed, it wasn't until the dawn of the modern nationalism in the I9th century and the legislation of 1828 that the heritage discourse became a communal matter on a larger scale and that all monuments were considered worth protecting irrespective of whose property they were situated on (SFS I 828:78). And, as could be expected, the care of the heritage was during the entire I9th century notoriously motivated by its primary role in the strengthening of Swedish nationalism (Jensen 2009:I 6I).

In today's post-national, Europeanized and globalized society, it is often argued that the local and regional perspectives have become all the more important within identity-creating processes, and that this in turn has stimulated a profound interest in the local heritage. That is true, but it is also true that a regionalization can be discerned already in the 18 th century as a result of the end of Sweden as a great power. The process continued in the century to come, partly due to the movement of modernization, i.e. industrialization, urbanization and increasing internationalization. As it turned out, the rising regionalism in the I 9 th century - which can be defined as a provincial form of nationalism - ended in a clash between the official representatives of the heritage management and the private and local stakeholders. The latter were organized in regional heritage associations with a joint center of organization, Svenska fornminnesföreningen, founded in 1869 .

Historical examples clearly indicate that matters of identity and the view of ownership of the heritage are intimately linked. The conflict outlined above revolved around the issues of who owned the heritage, who had the right to explore it, and who was responsible for its care: the individual citizen or the state, whose power and authority increased during the second half of the century (see also Jensen forthcoming; Hillström 2006:I37-I49). Within the central administration it was repeatedly argued that it was the state, and hence the population as a whole, who was the prime owner, not the landowner or the person who happened to find an object listed in the Ancient Monument Act. Accordingly it was primarily the interest of the collective, and not the individual, that ought to be prioritized.

A comparison with Norway and Denmark reveals a somewhat different situation. Private ownership and regional independency were more highly appreciated in both of these countries. This included the ownership of and the practice of private ventures connected to the lo- 
cal heritage (see Lidén 2005:208-2 I 5; Mahler et al. I983:29ff). That is partly why Norway did not ratify its first Ancient Monument Act until I 905 and Denmark as late as I937. In Denmark the preservation of monuments was previously based on the landowner's voluntary protection and on the practice of guarding singular monuments judged as extra valuable (Mahler et al. I983:29ff; Nielsen 200I). In Norway the authorities took Sweden as an example of why they should not pass a legislation at the end of the I9th century - the main argument was that it would inhibit private ownership of both the land and the actual heritage situated on it (Lidén 2005:208-21 5).

\section{KNOWLEDGE AND SCIENTIFIC VALUE AND VALUE CONTROVERSIES}

By knowledge value (or cognitive value, see Beckman I993) is simply meant that the heritage is considered a source of information, through which various kinds of knowledge can be constructed. Already in the I 7 th, I 8th and early I9th centuries, the preservation of monuments was partly motivated by moral, pedagogical and didactical aspects the view that monuments were material witnesses of a past qualitatively superior to the present. However - and even if ancient monuments gained attention as objects of knowledge already in line with the dawning empiricism and the scientific revolution - it was not until the I 9 th century and especially its second half that care of monuments was actually motivated by their scientific value ( $\mathrm{Sw}$. also preparatsvärde). This coincided with the rise of scientism (see Baumer I970:I33ff) and the professionalization of the heritage management along with its integrated fields of knowledge, such as archaeology, ethnology, and the history of art and architecture (Geijer 2004; Gillberg \& Jensen 2007). The process of professionalization and scientification implied that numerous domains of knowledge turned into professions, defined as specialized occupations based on formal, preferably academic, education (see Golinski I 998:66ff; Kärnfelt 2000:I3 8ff). Concurrently it also implied the exclusion and the marginalization of the non-official actors within the heritage movement who had previously been regarded as important local representatives from a national perspective.

The professional practitioners soon claimed that it took a trained eye and years of full-time practice to discern the real values embodied in the heritage (Gillberg \& Jensen 2007). With real values were primarily meant the material, style and aesthetic of the heritage, not in- 
tangible features such as folklore and public views expressed by the locals, information that was formerly appreciated by all parties (see also Zachrisson I997:2I). As a result, scientific values were perceived as superior since they were said to deepen the understanding of, and reveal the authenticity of, the heritage itself - in the Ancient Monument Act of I 867 the concept of science was mentioned no less than three times (SFS I 867:7I). The supremacy of scientific value was also motivated by that it was founded on objectivity and that it therefore was in the interest of the public in general and not of mere isolated and singular interests (Jensen forthcoming; see also Wetterberg I992:98f).

The pre-eminence of the scientific value was underlined in 1922 in a government commission evaluating the reorganization of Swedish heritage management. In line with the I 9 th-century rhetoric of nationalism, the commission concluded that the main aim of the care was to foster love of one's country (SOU I 922:I I-I2). This preservation strategy had previously primarily revolved around the motive of reverence which, according to the commission, had produced a narrow-minded view of the heritage definition. In the same sentence it was stated that recent developments within the field of science (i.e. archaeology and the history of art and architecture) had produced a richer and far more nuanced understanding of monuments and buildings from the past. Indeed, the scientific value had in fact turned out to be the most essential one since it had not only deepened our understanding of the heritage but also stimulated the public's interest. To put it briefly, other values (reverence, national identity, etc.) were in deep need of science to correctly understand the essence of the heritage.

The altered perspective outlined above clearly indicates why the values of knowledge and science came to dominate the ideology of preservation during most of the 2oth century, reaching its peak with the neo-positivism of the I960s and 70s. Consequently, the focus of interest has been on material features (see also Zachrisson 1997:21; Jensen 2006:29). The above perspective also enlightens us as to why the concept of 'authenticity' has had such immense importance in the preservation since it is said to reflect the original intentions behind the construction of the heritage.

As it turned out, this shift of focus did not go unchallenged. Far from everyone perceived the value of reverence and the intangible features of the heritage as outdated, and among the private enthusiasts there was a certain reaction against the professionalization and the increasing state 
authority. An illustrative example of these diverse attitudes is the artist Gunnar Hallström's contribution to a conference held in I92 I called "Arkeologerna och vården av de förhistoriska fornminnena" "Archaeologists and the care of prehistoric monuments") (RIG I922). Several well-known Swedish archaeologists including Sune Lindqvist, Birger Nerman, Oscar Montelius and Hanna Rydh participated. Hallström criticized the increasing number of excavations of monumental prehistoric graves since this threatened to diminish their reverence value. Their monumentality and the knowledge that there were still forefathers resting in the graves had a cultural value, Hallström stressed, a value which in turn was augmented by the colorful myths and legends associated with them (RIG I922:4ff).

In a rather disparaging tone the archaeologist T.J. Arne replied that archaeologists, too, had feelings of reverence for the graves, though not in the same sense as laymen. Instead, the professionals' reverence was performed rather than felt, through their careful explorations and detailed documentation (RIG I 922:9ff). It should be noted, however, that in an earlier stage of the professionalization the expert's right to excavate was not taken for granted. In the first decades of the I 9 th century it was repeatedly argued that only those with scientific training should be allowed to perform excavations (Jensen forthcoming). In his extensive article on monuments and archaeological practice, Johan Haqvin Wallman stressed that even as a scholar, i.e. as an archaeologist, you had to recognize your limits to perform excavations out of respect for the forefathers and the ethical value of grave protection. When selecting objects for excavation, you should consequently concentrate on monuments that were already damaged and disturbed (Wallman I 83 8:5 If).

In time, divided opinions on the assessment of the heritage would split the professionals, too. At the turn of the 2oth century the field of preservation of buildings was represented by both antiquarians and architects. Whereas the former advocated a more materialistic approach emphasizing the value of knowledge, the latter promoted a more artistic one, the visual and the aesthetic, and therefore lay more stress on reverence and emotive values (Wetterberg I992:98f). This split between an objectified historical and an architectural holistic approach had for a long time an immense influence on the debate on the valuation of the cultural heritage in general and on the building heritage in particular (see Krus 2006:34). 


\section{THE VALUATION OF MONUMENTS}

\section{AND CULTURAL LANDSCAPES}

For centuries a monument was valuated according to its monumentality and the degree to which it could be associated with a historical person or an event. The legislation of $\mathrm{I} 828$ comprised a list of all categories of monuments considered worth saving. However, in one of its drafts we learn that the original plan was that the forthcoming law would only concern very specific monuments, and that it was merely to prevent these from being accidentally destroyed that the legislation should also be valid for less remarkable ones ("PM I0.3 I 828 ", vol. 6, serie FId, GF\&JAA, ATA).

Due to its rather uniform definition based on different Ancient Monument Acts ( I666, I 828, I 867 and I942) the selection of monuments that ought to be protected was seen as fairly unproblematic for quite some time. In the I970s, however, things started to change. It was a decade of upheaval in the history of valuation as the very concept of cultural heritage was radically reassessed. The evolving functional, ecological and economical understanding of man and society led to a shift of focus concerning remains from the past. Up until then the key monuments cared for were prehistoric and medieval ones. In line with the dominating scientific perspective they were first and foremost appreciated as sources of information since they represented times with few if any written testimonies (e.g. SOU I922:I I, p. 7; Curman I936:234). The variety of monuments and their chorology were fairly well known thanks to a nationwide inventory that had been carried out since the I930s. Based on decades of experience, and influenced by the ideas of processual archaeology, a decision was made to add functional and economically defined remains used in the sphere of past production and support to the concept of monuments (Selinge 1974; Jensen 2006:40f). To some extent this approach also affected the selection of buildings that were defined as worth saving from a cultural historical perspective (Unnerbäck 1976:26).

A second interacting feature was the alarming state of affairs of the environment and the heritage itself. The immediate and all too obvious threat was the large-scale infrastructural projects, the exploitations of cultural landscapes, and the extensive obliteration of old urban areas. There was a growing awareness that cultural values could easily be replaced by other societal values. And in order to minimise the dam- 
ages and assimilate the care of both the environment and the heritage in long-term societal planning (Sw. fysisk riksplanering), the Swedish National Heritage Board was commissioned to select and list cultural landscapes perceived as extraordinary valuable from a national and a regional perspective (Thor I972).

To realize the plan it was necessary to have a well supported value system covering not only single objects but entire cultural landscapes. A main issue concerned the classification of monuments, buildings and cultural landscapes and their spatial pattern in various parts of the country (see Selinge 1974; Meschke (Ed.) 1973; Hyenstrand 197I). The initial idea was to select landscapes representing different types of use and various cultural expressions (see Hyenstrand I990:29). In his plan for preservation from I97I, Åke Hyenstrand listed three different foundations of value (Sw. värderingsgrunder): a statistical one that referred to the actual objects (preferably monuments); a topographical one that focused on the environment in relation to the monuments; and, lastly, a historical one representing the historical development of buildings (I97I:2f).

This shift of focus - from single monuments to a more holistic perspective in both time and space - implied a redefinition and an extension of the concept of heritage to include entire landscapes. As a sign of the time Klas-Göran Selinge summarized the situation by stating that the prime requirement for a monument to be classified as worth protecting was that it was abandoned, whereas its age was of secondary importance (Selinge I974:I4). The new categories and expressions of values that were introduced - such as "human ecological", "valuable cultural historical environments", "environmental value" and "values in relation to environmental perspectives” (Cullberg I974; Janson I974:2 I I; Forsström I978) - clearly mirror the present stress on ecology and the environment.

\section{THE SOCIAL VALUE AND DEMOCRACY AND THE ASSESSING OF THE ARCHITECTURAL HERITAGE}

The I970s can also be characterized as the decade when democratic motives were introduced into the sector of Swedish heritage management. In line with the welfare strategy and the official cultural policy the heritage was perceived as a democratic and vitalizing force. To have and to make use of the heritage, it was argued, was a vital human right. And instead of being isolated objects that ought to be pro- 
tected from the people, the heritage was valuated as an integrated social force in the everyday life of the citizens (see also Jensen 2006:38; Harding 2007:169).

In line with this shift of perception, emotive values but also use values were upgraded. The values emphasized were the social and (local) identity aspect (see also SOU I965:I0; SOU I97 I:75, p. I 84) and above all the scientific value since the former, it was argued once again, was dependent on the results of the latter (Meschke (Ed.) I973:49; Selinge I972:I I; I974:24). As Axel Unnerbäck put it: "Until as recently as the I970s, the mention of such emotive values as beauty and identity value was virtually taboo in heritage management: only objective, scientific arguments were permissible when pleading for the preservation of a building or part of it" (Unnerbäck 2000:3 I). However, this approach "became impossible at a time when society was beginning to demand that heritage management should safeguard not only the traditional historical monuments but also the overall physical social environment, environments illustrating social conditions and helping to give people a sense of identity and historical belonging in their everyday surroundings", and hence, "at the beginning of the I980s, an approach was manifested whereby the emotive values had to be allotted the same weight in a preservation case as the traditional scientific properties" (Unnerbäck 2000:3 If).

In 1974 Sverker Janson published his thought-provoking book Kulturvaird och sambällsbildning in which he drew attention to the present disturbing situation - the assessment of the heritage. The discussions within the heritage management were, according to Janson, at a minimum. This left much to be desired; the valuations made were often unfounded and since the concept of heritage had changed it was no longer enough to rely on an old value system that focused merely on the monuments and on criteria such as age and rareness. In his summary of the situation, he stated that older norms "no longer meet the requirements as the heritage is placed in a wider context, or when the concept has gained a wider meaning" (I974:206, my translation).

A closer examination disclosed a major difference between the assessments of monuments and those of the architectural heritage. According to the definitions and categories given in the legislation, all monuments were generally protected by the law, and their locations were pretty well known thanks to the nationwide inventory. The legislation concerning buildings was weaker except with regard to an ex- 
clusive and limited selection (Janson I974:2 I Iff). Janson saw the legal protection of monuments as a model and therefore recommended that buildings should be assessed according to a principle based on certain categories of "value groups", representing different classes of buildings. The value groups in question were divided into architecturally, administratively, traditionally and functionally designed buildings. Furthermore he emphasized the importance of listening to the public's views on what ought to be preserved (Janson I974:2I4). In this context it should be noted that Janson was not the first to advocate a standard of protecting buildings founded on a comprehensive inventory and on the same principles as monuments - this was done already in 1902 by the Royal Academy of Fine Arts in their proposal to improve the care of old buildings (Wetterberg I992:69). Their attempts were neglected, however!

Initially, the democratic movement regarding the heritage was fostered by the Second World War and the devastating destruction of monuments and architecture on the Continent. The systematic bombing of urban areas and the later remodelling of the same areas in line with the post-war urban development highlighted the need for adequate protection of old buildings. A year after Janson's book was published, in I975, the issue of preserving buildings was once again emphasized by the European Council which culminated in the European Charter of the Architectural Heritage (see "Byggnadsvårdsåret I975", F 3 b, Kulturhistoriska byrån, ATA). Ten years later, the European Council ratified the Convention for the Protection of the Architectural Heritage of Europe which aimed to endorse the practice and the legislation on the preservation of buildings (Robertsson 2002:30f).

The proclamations in question caused the Swedish National Heritage Board to initiate task groups to evaluate preservation and definitions of cultural historical values in relation to the architectural heritage. One of the task groups performed their work in the I980s and 9os. Their main results were later presented in two highly influential books, one practically orientated, Fem pelare - en vägledning för god byggnadsvård (Robertsson 2002) and one theoretical, Kulturhistorisk värdering av bebyggelse (Unnerbäck 2002). According to their model, values could be divided into two major categories, documentation/ knowledge and emotive, each with several sub-values. Already in 1995 , some of the results were presented in a paper by Axel Unnerbäck and Erik Nordin (Unnerbäck \& Nordin I995). In a critical evaluation pre- 
sented in the same year, however, their model was portrayed as an unfounded mix of subjective and objective theories of values (Almevik \& Fridén 1995). But the question is: does it have to be a paradox to concurrently invoke both objective and subjective values in relation to the heritage? The answer is that it depends on how you define the meaning of values.

\section{VALUE THEORIES AND HERITAGE VALUES IN A MELTING POT}

Opinions on how to perceive the very essence of values are divided. These differences are essentially based on different ontological perspectives and on various views on how to relate values to what are commonly referred to as facts (see Hollinger I 994:59ff; Bergström 2004). To put it simply, from an objective perspective values are perceived as facts and hence something that universally exists - some would even argue that they have empirical features that can be scientifically evaluated (i.e. value naturalism). As could be expected, from a subjectivist stance values are understood as nothing but personal or intersubjective interpretations; they are relative and therefore historically bounded. However, a circumstance that is notoriously overlooked from a heritage perspective is that even though they have diametrically opposed views when it comes to the essence of values, value objectivism and value subjectivism have the same idea when it comes to facts which they both perceive as objective. This is of major importance since categories of values such as knowledge, documentation and science are generally perceived as facts from an objective perspective. The philosopher Henrik von Wright summarizes the value of subjectivism in the following way: "It denies that there are common, objective yardsticks for good and evil, right and wrong, beauty and ugliness. When you disagree about facts you usually can establish what opinion is right and which are false. Not so when there are disagreeing opinions concerning value issues" (von Wright I990:86, my translation).

Now, if we take a closer look at the value system presented by Unnerbäck and Nordin it will be apparent that it is actually based on this particular value theory and not, as was suggested in the critical evaluation, on an illogical mix of subjectivism and objectivism. This should not, however, come as a surprise considering that the most influential value theory in modern time is precisely the subjective one that is generally based on the Cartesian dualistic approach implying that 
values are subjective and facts objective. That is why the value arguments, put forward during the I9th and especially the 2oth century, were generally based on the Cartesian subjectivism. And that is why we so persistently, from a heritage management perspective and especially in the case of monuments, often still refer to the old hierarchical principle of scientific and emotive values respectively: "The two most essential value criteria are slide value, or scientific value, and emotive value, or pedagogical/social value. Of these slide value is considered the prime value base" (see Bilaga I in Blomqvist 2004, my translation; for an identical earlier example, see also Jensen I993:64; for a reverse attitude, see Johansen \& Eklöf 2003:7f).

Hence in some sense it is fair to say that value subjectivism has in itself become an important element of the heritage. This is partly true for value objectivism as well since it has not yet been outdated (but see Almevik \& Fridén 1995:93). The examples in which it is argued that values in general can be evaluated from an objective perspective-since they are thought to be immanent in the heritage itself - are numerous. Indeed, the notion of objectivity is at the very core of the idea that we can discern the right aesthetic, social, symbolic, traditional, societal and historical value and meaning of an artifact, a landscape, a building or a monument, and that there is something that could be distinguished as a national, European or world heritage.

\section{THE LOCATION OF VALUES AND THE INSTRUMENTALIZATION OF HERITAGE}

Already in the early I9th century, Nils Henrik Sjöborg motivated the care of ancient monuments in the landscape with arguments that it was important for the local population and for the satisfaction of travellers in the countryside ("Plan ...", vol. 3, serie FIV, Äa 2, ATA). The latter argument was also emphasized later, in I 859 , by the National Antiquarian Bror Emil Hildebrand (“Motiver ...”, FIV:3, Äa 2, ATA). Much later, in an evaluation of the heritage management from I965, the value of the heritage within the tourism industry and for recreation during leisure time and holidays, defined as social value, was underlined (SOU I965:IO, s. 69ff; see also SOU I972:45, p. 76 - the first Swedish holiday reform was authorized in I938). Since then, especially since the 1980 s and most notably the I990s, areas in which the heritage is perceived as potentially useful have expended radically. More explicitly than ever the heritage is now treated as a resource - it has become se- 
verely instrumentalized - to be used in various contexts, such as in the experience industry, for recreation, and in the economic development on a regional scale (Weissglas et al. (Eds.) 2002; Vestheim 2008; Remmare \& Peronius (Eds.) 2008). Hence, the search for new uses within today's consumerism has enhanced the urge to identify values that can be used within the growing market of attraction and experience. This state of affairs has contributed to the awakening of an old philosophical question: where exactly is the value of the heritage situated; in the heritage itself, in our minds (or, from a discursive perspective, in the language) or somewhere in between?

The concept of intrinsic values (Sw. intrinsikalt, inneboende or egenvärde - some see a difference between intrinsikalt värde and egenvärde while others do not, see Olsson 2002:5 $\mathrm{I}-52$ ) is generally associated with the theory of objectivism since values are believed to be immanent in the heritage itself (Almevik \& Fridén 1995:93). The examples in which intrinsic values are defined in terms of emotive, document, knowledge and use are numerous: But how could it be argued that the heritage has innate values of its own - is the idea based on some kind of animism? A quite common argument for the preservation of the heritage can be exemplified with the following quotation: "The cultural heritage has an intrinsic value [egenvärde] of its own, just by being a cultural heritage" (Vägar till kulturarvet 2004, my translation). There is reason to assume that at the core of this circular argument rests a notion of the heritage having some sort of inner objective force of its own that makes it worth saving; either because it is recognized as a universal phenomenon - a conclusion that has been criticized - or because material features automatically transform into heritage due to a certain age, rareness, etc. Yet another idea often expressed in this context - which I will return to further on - is that the heritage has some sort of undefined innate power that can be used for recreation and emotive purposes (Remmare \& Choulier-Renström 2008:I7). A third and the most commonly cited idea about innate values is the notion that documentation, knowledge and science are objective and therefore intrinsic. As we all know, objectivism has been severely criticized in the last decades, also within a heritage management context (Smith 2006:5 I-57). It could also be argued that the choice of which features and details to document, and how they are perceived, is not settled once and for all but is arbitrary depending on what kind of knowledge is being sought and which epistemological tradition filters our perception. 
In recent years there is a growing tendency to abandon the idea of intrinsic values, or at least to combine it with what is referred to as extrinsic values, or instrumental values which is often taken as a synonym. From this perspective it follows that the heritage has no value of its own. Heritage is rather the means by which values can be achieved and which in turn can stimulate man's intrinsic values such as content, happiness and existential orientation ( $c f$. hedonism). From an extrinsic perspective it could be argued that recreation and experience are not the outcome of some innate value of the heritage, but rather the emotions and feelings brought to life in man as a result of visual contact, experience or mere awareness of the heritage. As could be expected, the notion of extrinsic or instrumental values is often expressed in relation to the utility of the heritage; it is also often associated with a more relativistic approach. In the heritage proposition from I 998 (Regeringens proposition 1998/99:II4) and in an investigation concerning the industrial heritage presented in the following year (SOU I999:I 8), heritage values were defined as socially and historically constructed and therefore relative in character. Hence this perspective was characterized as "instrumental" since the heritage, we are told, is nothing more than the result of our mere desire for it for different purposes (SOU I999: I 8, p. IIf).

\section{VALUE CONSTRUCTIVISM IN LATE MODERN SOCIETY}

More recently, the number of critical evaluations of values related to the heritage has increased dramatically (e.g. Beckman I993; Carlie \& Kretz 1998; Olsson 2003; Krus 2006; Pettersson 2003; Dahlström Rittsél 2005; Westin 2005). This in turn is due to a number of interrelated factors. One of these is the increase in new value systems within the heritage management based on new criteria (such as economy, narratives, etc.). The second is that heritage values are more regularly compared to other societal values such as social welfare, recreation and the market. Both of these situations have stimulated the need to evaluate the very nature of different value systems and their compatibility. Yet other circumstances are the ongoing international debate, the increasing public concern, and the pluralism of identities that has to be considered in the valuation of the heritage. The upgrading of the intangible heritage and the growing amount of new articles drawn into the heritage sphere are additional vital factors. When it comes to the latter, the search for arguments motivating why new features (such as 
the modern, the industrial and the so-called difficult heritage) should or should not be classified as worth saving has automatically led to an explicit assessment of heritage values.

In his article Randall Mason sums up a critical perspective on heritage values in the following generalized way: "The values of heritage are not simply 'found' and fixed and unchanging, as was traditionally theorized in the conservation field (i.e. the notion of heritage being intrinsic). Values are produced out of the interaction of an artifact and its context; they don't emanate from the artifact itself. Values can thus only be understood with reference to social, historical, and even spatial contexts - through the lens of who is defining and articulating the value" (Mason 2008:I00). Values are perceived as something that is socially constructed and negotiated and hence as a performative process of evaluation rather than something static and settled once and for all (Smith 2006). Whereas some argue that this process is entirely subjective, and thus has nothing or little to do with the materiality itself, still others, like Mason, emphasize the nexus between man and materiality - a value is the product of the actual context affected by social, political, economical and intellectual issues (see also Westin 2005:78). The philosopher Ayn Rand presents a similar idea in the following way: "Material objects as such have neither value nor disvalue; they acquire value-significance only in regard to a living being - particularly, in regard to serving or hindering man's goals" (Rand I984:79).

The movement towards a more relativistic approach is often ascribed to the influence of the postmodern theoretical debate that has been going on for the last decades (e.g. Höjer 2005; Roslund 2006 and contributions in Arkeologi - splittring eller maingfald? 2005 and in Verneideologi 2003). Values, it is argued, are now perceived as anything and nothing since the meaning has been disbanded. We currently live in a value-free world due to postmodern nihilism which has deeply affected the discourse of the heritage. Or has it? From a postmodern value-constructivist perspective-influenced by hermeneutics, phenomenology and poststructuralism - neither values nor facts are perceived as objective; "it abandons the dualisms of facts and values, objectivity and subjectivity, descriptions and interpretations, and gives all methodologies a political coloration while contextualizing all claims, methods, and values" (Hollinger I994:63). Now, if it is truly accurate that postmodern epistemology and ontology have had such an influence within today's Swedish heritage management, should we not be able 
to find quite a few examples of discussions based on a constructivist and discursive perspective on values, including trials of the value of knowledge, documentation and science?

As to the present Swedish debate on the assessment of the heritage, a perusal of texts reveals two characteristics. Firstly, when specific heritage features are considered, the focus is mainly on the modern part of the heritage and especially on buildings. The reason for the latter is the seemingly never-ending difficulty in assessing the building heritage, as buildings are often active components in the social sphere of life and used on a daily basis. It follows that you have to consider a vast number of interrelated social, cultural historical, functional and economical circumstances simultaneously in the process of assessing their value, which is seldom the case with monuments. For a building to reach the same status as a monument it has to be proven to be "extremely remarkable" from a cultural historical perspective (SFS I 988:950, 2 chapter I $\mathbb{S}$ ). Hence, while the valuation of monuments mainly concerns the topic of what is to be cared for, the issue at stake with buildings is how to motivate the care by finding the right values - this in turn draws the attention to the very meaning of value itself.

A second characteristic that can be distinguished is that most of the texts deal with emotive and use values whereas reflections on values of knowledge, documentation and science are conspicuously absent (for an exception to both of these features, see Carlie \& Kretz I998). It therefore seems safe to conclude that within today's discourse of heritage, values of knowledge, documentation and science have become black-boxed in the sense that they are taken for granted or perceived as secondary or even unimportant and therefore neglected. On the basis of my evaluation it could be argued, then, that a relativistic approach towards heritage is not so much explicitly based on postmodern theories. It is rather the post- or late modern era and the changing overall (societal) mentality and the consumerism that have influenced the heritage discourse in the sense that we are paying more attention to emotive and use values and to the intangible and instrumental features at the expense of values of knowledge, documentation and science. Finally and consequently, my impression is that even if postmodern epistemology to some extent has indubitably influenced the heritage debate, it is fair to say that the situation should rather be characterized as a radicalization of the Cartesian subjectivism which has already been dominating the field of heritage for centuries! 


\section{CONCLUSIONS AND FINAL REMARKS}

In Sweden, the care of what has been defined as cultural heritage has since the I 7 th century been motivated by the reference to different categories of value. The concept of value has mutated over time due to ontological, epistemological and existential transformations and changing ideas on man, society, identity, utility, and life and death (Jensen I998). In this article I have argued that some of these values have been more persistent and dominating than others. One of the oldest is the ethical value; that is, remembering and caring for the dead, including what was perceived as the heathen forefathers. This value of reverence, however, along with the intangible heritage, was marginalized from a management perspective at the expense of the value of knowledge and science during the course of the I9th and above all the 2 oth century. It is therefore interesting to note that the ethical value of remembrance as well as the intangible heritage has recently been revitalized within the heritage context (see e.g. Jonsson 2007; Convention for the safeguarding of the intangible cultural heritage 2003; cf. also today's issue of repatriation).

Needless to say, the history of heritage values has never been valuefree, but is always colored by the will to represent and to be represented and to manifest certain ideals with the ambition of making them prevail in the future. That is why the value of identity - and its rhetorical use within political discourses - has been the most consistent one throughout history. There are, however, different perspectives on man's role in the process of valuating and on the ontological status of the heritage, and presently we can discern various renderings on the subject that can roughly be divided into an objective, a subjective, and what we could call a constructivist (or a postmodern) perspective. Of these, the Cartesian subjectivism has by far, in fact for centuries, been the most lasting and influential.

The theoretical pluralism within today's heritage management could be perceived as a problem in the sense that it threatens to undermine the credibility of the assessments we make. Another way of looking at it is to simply accept the situation and hence face the fact that it merely mirrors the present variety of opinions, but also to reversely perceive the pluralism as a positive strength as it forces us to more explicitly argue and motivate our assessments. The latter has turned out to be of immense importance because the heritage management, as noted above, has become increasingly involved in other political and social spheres 
- (Sw. aspektpolitik; SOU 2009:I6, pp. 97-234; Regeringens proposition 2009/Io:3, pp. I I $2 \mathrm{ff}$ ) - but also because of the mounting numbers of both public and private stakeholders that want to assess the heritage on more or less the same terms as the official experts. Recent so-called governmentality studies convincingly demonstrate the way in which globalization, glocalization, post-nationalism and neoliberal reforms have altered the role of the state by diluting the traditional hierarchical and centralized political system, most notably in Europe including Sweden (Swyngedouw; Dean 1999; Lidskog et al. 2005). An increasingly influential deliberative democracy (which among other things assumes a pluralism of values), the increasing deregulation and privatization, decentralization and regionalization, but also the knowledge and network society, have all contributed to a reassessment of the relationship between the state and the civil society. Today's "governance beyond the state system" has "implied that non-state configurations [have] become increasingly involved in regulating, governing and organising a series of social, economic and cultural activities" and that "other and often new civil society organizations as well as private actors (stakeholders) [have] become involved in the act of 'governing'" (Swyngedouw, p. 5, 25).

The tendency today is that while the legitimacy of the official experts is weakened (e.g. Lidskog et. al. 2005; Höijer 2006), private actors, organizations and the market have become more influential, even in matters concerning heritage (Thomas 2008). On the one hand this situation can promote democracy in the sense that more people have the opportunity to actively participate in the processes of, as in this case, selecting and valuating the heritage. On the other hand there is also a risk that the same situation will threaten democracy if private, resourceful, marginalizing and even antidemocratic forces take precedence at the expense of public interests and of local as well as ethnic minorities (see also Aronsson 2002:I 82; Dahlstedt 2000; Lidskog et. al. 2005:24). In short, the democratic challenge that we as professionals and experts are facing today is to find a balance between a variety of interests, such as between short-term - often economic - interests and a long-term management perception (i.e. between present and future prospects), between various private and public interests, and between the pluralism of identities that characterizes society today. This requires a heritage management with the ability to critically reflect on current political, economical and social issues. It also requires an abil- 
ity to expose and challenge any discriminatory practices, and a management as well as a cultural policy that has the strength to act in an emancipating way. But to make this happen we must continue to ask relevant questions about how heritage is valuated and to assess interests behind value judgments. My ambition with this article has been to illustrate that this could indeed be facilitated by taking a stance on how things were in the past!

Ola W. Jensen, The Swedish National Heritage Board, Box 5405, SE-I 484 Stockholm, Sweden

\section{Acknowledgement}

This article was written within the frames of my project financed by the Royal Swedish Academy of Letters, History and Antiquities and Riksbankens Jubileumsfond. I also want to thank Åsa Gillberg and Åsa Wall for commenting on the text. 


\section{References}

Almevik, G. \& Fridén, B. 1995. Vad kostar ett kulturarv? Kulturmiljövård. Nr. 5/6. Pp. 92-I00.

Arkeologi - splittring eller mångfald? 2005. Stockholm: Riksantikvarieämbetet. (www.raa.se/publicerat/rapp2006_I.pdf)

Aronsson, P. 2002. Demokrati och upplevelsehistoria. In: Aronsson, P. \& Larsson, E (Eds.). Konsten att lära och viljan att uppleva. Historiebruk och upplevelsepedagogik vid Foteviken, Medeltidsveckan och Jamtli. Rapport nr. I. Pp. I80-I90. Växjö universitet: Centrum för kulturforskning.

Baumer, F. L. I970. Skeptiker och sökare. Fyra århundraden av religiöst tvivel och sökande efter en tro $i$ Västerlandet. Stockholm: Rabén \& Sjögren.

Beckman, S. I993. Om kulturarvets väsen och värde. In: Anshelm, J. (Ed.). Modernisering och kulturarv: Essäer och uppsatser. Pp. 6I-I 24. Stockholm/Stehag: Brutus Östlings Bokförlag Symposion.

Bergström, L. 2004. Grundbok i värdeteori. Stockholm: Bokförlaget Thales.

Biörnstad, M. I990. En verksamhetsidé för 9o-talet. Kulturmiliövård. Nr. 4. Pp. I-6.

Blomqvist, Malin. 2004. Informationssystemet för fornminnen - lista med lämningstyper och antikvarisk praxis. Stockholm: Riksantikvarieämbetet.

Carlie, A. \& Kretz, E. I998. Sätt att se på fornlämningar. En teoretisk och metodisk grund för värdebedömning inom kulturmiljövården. Report series No. 6o. University of Lund: Institute of Archaeology.

Convention for the safeguarding of the intangible cultural heritage. 2003. UNESCO.

Cullberg, K I974. Beskrivning av kulturhistoriskt värdefulla miljöer. Meddelande från Riksantikvarieämbetet. 1974:8. Pp. 2-I3.

Curman, S. I936. Vita fläckar på Sveriges karta. Föredrag i Svenska Sällskapet för antropologi och geografi Vegadagen I936. YMER. Femte årgången. Pp. 23 I-264.

Dahlström Ritssél, E. 2005. Värdering i inventeringar. In: Alzén, A. \& Burell, B. (Eds.). Otydligt. Otympligt. Otaligt. Det industriella kulturarvets utmaningar. Pp. 55-76. Stockholm: Carlsson Bokförlag.

Dahlstedt, M. 2000. Demokrati genom civilt samhälle? Reflektioner kring Demokratiutredningens sanningspolitik. Statsvetenskaplig Tidskrift. Årg I03. Nr 4. Pp. 289-3 го.

Dean, M. 1999. Governmentality: Power and rule in modern society. London: Sage Publications.

Forsström, M. I978. Kulturminnesvården i den fysiska riksplaneringen. Kulturminnesvård Nr. I. Pp. I-I4.

Geijer, M. 2004. Ett nationellt kulturarv. Utvecklingen av en professionell vård och förvaltning av statliga byggnadsminnen. Stockholm: Kungl. Tekniska Högskolan, Institutionen för infrastruktur.

Gillberg, Å. \& Jensen, O. W. 2007. Processes of professionalisation and marginalization. A constructivist study of archaeological field practices in Sweden I870I9IO. In: Bentz, E. \& Rudbeck, E. (Eds.) Arkeologins mainga roller och praktiker. Pp. 9-33. Lund: Lunds universitet, Institutionen för arkeologi och antikens historia.

Golinski, J. I998. Making natural knowledge. Constructivism and the history of science. Cambrige: Cambridge University Press.

Harding, T. 2007. Nationalising culture. The reorganisation of national culture in Swedish cultural policy 1970-2002. Linköping studies in arts and science No. 393. Linköping: Linköping University. 
Harrison, R. (Ed.). 20I0. Understanding the politics of heritage. Manchester and New York: Manchester University Press.

Hillström, M. 2006. Ansvaret för kulturarvet. Studier i det kulturhistoriska museiväsendets formering med särskild inriktning på Nordiska museets etablering I872-1919. Linköping studies in art and science 363. Linköping: Linköping University.

Hofberg, H. I 87 I. Förteckning öfver Nerikes fasta fornlemningar. Jemte en inledande beskrifning, och utdrag af Kongl. Maj:ts nådiga förordning af den 29 nov. I 867, angäende forntida minnesmärkens fredande och bevarande. Örebro.

Hollinger, R. 1994. Postmodernism and the social sciences. A thematic approach. Contemporary social theory. Vol. 4. London \& New Delhi: Sage Publications.

Hyenstrand, Å. I97I. Bevaringsplanering I. Statistik på fornlämningar. Metodförslag med tillämpning på Skaraborgs län. Rapport Dı. Stockholm: Riksantikvarieämbetet.

Hyenstrand, Å. I990. Från fysisk riksplanering till naturresurslagens riksintressen. Kulturmiliövård. Nr. 2. Pp. 26-34.

Höjer, H. 2005. Bråket om kulturarvet. Forskning och framsteg. Nr. I/05.Pp. 24-27.

Höjer, H. 2006. Forskarens auktoritet i gungning. Forskning och framsteg. Nr. 6/o6. Pp. 24-3I.

Janson, S. 1974. Kulturvård och sambällsbildning. Nordiska museets handlingar 83 . Lund: Berling.

Jensen, O. W. 1998. The cultural heritage: Modes of preservation and the longing for eternal life. In: Andersson, A-C et al. (Eds.). The kaleidoscopic past. Proceedings of the 5th Nordic TAG conference Göteborg, 2-5 April 1997. Pp. 99-I I 8. GOTARC serie C, Arkeologiska skrifter no. I6: Göteborg: Department of Archaeology.

Jensen, O. W. 2004. Earthy practice. Towards a history of excavation in Sweden, in the I 7 th and I 8th centuries. Current Swedish Archaeology. Vol. I 2. Pp. 6I-82.

Jensen, O. W. 2006. Fornlämningsbegreppets historia. En exposé över 400 år. Stockholm: Riksantikvarieämbetet.

Jensen, O. W. 2009. "Fornforskning är att vilja uplyfta nationalespriten". Om forntidsuppfattning och minnesvård i I 800 -talets nationalisering av Sverige. In: Edquist, S. et al. (Eds.). Tankar om ursprung. Forntiden och medeltiden i nordisk historieanvändning. Pp. I 59-I78. Stockholm: Statens historiska museum.

Jensen, O. W. (forthcoming). Mellan dilettantism och professionalism: Om konstruktionen av vetenskapliga självbilder inom I 80o-talets svenska minnesvård och arkeologi. In:Hadocs, H \& Federhofer, M-T. Mellom pasjon og profesjonalisme. Dilettantkulturer i skandinavisk kunst og vitenskap mellom I660-I970. Tapir Akademisk Forlag: Trondheim.

Jensen, R. I993. Särskilda arkeologiska utredningar och fornlämningsbegreppets tillämpning. In: Varenius, B. (Ed.). Särskilda arkeologiska utredningar. Metodkonferens i Örebro I992. Rapport RAÄ I993:4. Pp. 59-74. Stockholm: Riksantikvarieämbetet.

Johansen, B. \& Eklöf, I. 2003. Inledning. In: Olsson, R. Fasta Fornlämningar - begrepp och begriplighet. Pp. 5-ı0. Stockholm: Riksantikvarieämbetet.

Jonsson, S. 2007. Rätten till kulturarvet. Riksantikvarieämbetets höstmöte, I3 november 2007. (Stencil).

Krus, A. 2006. Kulturarv - funktion - ekonomi: tre perspektiv på byggnader och deras värden. Göteborg studies in conservation, I7. Göteborg: Chalmers tekniska högskola.

Kongl: Mayst:tz Placat och Påbudh om Gamble Monumenter och Antiquiteter, I 666. 
Kulturmiljön som resurs: Hur kulturmiljöaspekterna på ett ändamålsenligt sätt kan behandlas i miljöbedömningar och miljökonsekvensbeskrivningar. 2007. Stockholm: Riksantikvarieämbetet.

Kärnfelt, J. 2000. Mellan nytta och nöje. Ett bidrag till populärvetenskapens historia $i$ Sverige. Stockholm/Stehag: Brutus Östlings bokförlag Symposion.

Lidén, H-E. 2005 . Nicolay Nicolaysen. Et blad av norsk kulturminneverns historie. Oslo: Abstrakt forlag.

Lidskog, R, Sundqvist, G. \& Uggla, Y. 2005. Risk, expertis och demokrati. Allmänhetens inflytande i sambällets riskhantering. STS Research Reports No Io. Göteborg: Avd. för teknik- och vetenskapsstudier. (http://www.externarelationer. adm.gu.se/digitalAssets/I030/I03039I_sts_report_Io.pdf)

Lindblad, H. 2009. Värderingar och prioriteringar. Etapp 2 av projektet Utvärdering och utveckling av karaktäriseringar och prioriteringar. Svenska kyrkan.

Mahler, D. L., Paludan-Müller, C. \& Stummann Hansen, S. I983. Om arkcologi. Forskning, formidling, forvaltning - for hvem? København: Hans Reitzels Forlag.

Mason, R. 2008. Assessing values in conservation planning. Methodological issues and choices. In: Fairclough, G. et al. (Eds.) The heritage reader. Pp. 99-I24. London and New York: Routledge.

Mathers, C., Darwill, T. \& Little, B. J. (Eds). 2005. Heritage of value, archaeology of renown: Reshaping archaeological assessment and significance. Florida: University Press of Florida.

Meschke, C. (Ed.) I973. Kulturlandskapet i älvdalarna. Rapport D3. Stockholm: Riksantikvarieämbetet.

Nielsen, N. L. 200I. Museer i oprør. Provinsmuseerne og Nationalmuseet i en brydningstid. KUML. Pp. I I I-I 58.

Olaus Magnus 200I [ I 55 ]. Historia om de nordiska folken. Hedemora: Gidlunds förlag.

Olsson, K. 2003. Från bevarande till skapande av värde. Kulturmiljövården i kunskapssambället. Stockholm: Institutionen för infrastruktur, Kgl. Tekniska högskolan.

Pettersson, R. 2003. Den svenska kulturmiljövårdens värdegrunder. En idéhistorisk bakgrund och analys. Landskapet som arena 7. Umeå: Umeå universitet.

Rand, A. I984. Philosophy: Who needs it? New York: Signet.

Regeringens proposition I 998/99: I I 4. Kulturarv - kulturmiljöer och kulturföremål.

Regeringens proposition 2009/IO:3. Tid för kultur.

Remmare, P-O \& Choulier-Renström, A. 2008. Kulturarv och naturarv som lokal och regional utvecklingsfaktor - vad kan det vara? In: Remmare, P-O \& Peronius, E. (Eds.) Kulturarv och entreprenörskap. Dokumentation av konferens i Jönköping IO-I I maj 2007. Pp. I3-2 I. Stockholm: Riksantikvarieämbetet.

Remmare, P-O \& Peronius, E. (Eds.). 2008. Kulturarv och entreprenörskap. Dokumentation av konferens i Jönköping IO-II maj 2007. Stockholm: Riksantikvarieämbetet.

RIG. I922. Arkeologerna och vården av de förhistoriska fornminnena. Bd 4, I92 I. Pp. I-I 8 .

Robertsson, S. 2002. Fem pelare - en vägledning för god byggnadsvård. Stockholm: Riksantikvarieämbetet.

Roslund, M. 2006. Mannaminnet räcker inte till. Om arkeologin som politiskt medel för nutid och framtid. Fornvännen. Nr. Iог. Pp. I98-204. 
Schück, H. I932. Kgl. Vitterhets-, historie- och antikvitetsakademien. Dess förhistoria och historia I. Stockholm.

Selinge, K-G I972. Kulturhistorisk riksplanering - en metodstudie. In: Miljöer och större områden av betydelse för kulturminnesvården. Förarbete för fysisk riksplanering. Underlagsmaterial nr. 23. Pp. I I-39. Stockholm: Civildeparementet. (Stencil).

Selinge, K-G. 1974. Kulturlandskapet - översiktlig dokumentation och planering. Rapport D4 1974. Stockholm: Riksantikvarieämbetet.

SFS I 828:78. Kongl. Maj:ts Nådiga Förordning, angående forntida Minnesmärkens fredande och bewarande: Giffwen Stockholms Slott den I7 april I 828.

SFS I 867:7 I. Kongl. Maj:ts Nådiga Förordning, angående forntida Minnesmärkens fredande och bewarande: Giffwen Stockholms Slott den 29 november I 867.

SFS I942:350. Lag om fornminnen.

SFS I988:950. Lag om kulturminnen m.m.

Smith, L. 2006. Uses of heritage. Abingdon and New York: Routledge.

Smith, G., Messenger, P. M. \& Soderland, H. A. 20Io. Heritage values in contemporary society. Walnut Creek: Left Coast Press.

SOU I922:I I-I 2. Betänkande med förslag till lag angående kulturminnesvård samt organisation av kulturminnesvarden. Stockholm.

SOU 1965:I0. Antikvitetskollegiet. Centralorgan för svensk kulturminnesvård. Betänkande avgivet av antikvarieutredningen. Stockholm.

SOU I971:75. Hushållning med mark och vatten. Stockholm.

SOU I972:45. Kulturminnesvård. Betänkande av 1965 års musei- och utställningssakkunniga. Stockholm.

SOU I999:I 8. Frågor till det industriella sambället. Slutbetänkande av Utredningen om en statlig satsning på det industrihistoriska kulturarvet. Stockholm.

SOU 2009:I6. Betänkande av Kulturutredningen. Förnyelseprogram. Stockholm.

Swyngedouw, E. Let the People Govern? Civil Society, Governmentality and Governance-Beyond-the-State. Paper submitted to: Urban studies (special issue SINGOCOM) (http://socgeo.ruhosting.nl/colloquium/humboldt.pdf)

Thomas, R. M. 2008. Archaeology and authority in the twenty-first century. Pp. I39-I 48. In: Fairclough, G. et al. (Eds) The heritage reader. London and New York: Routledge.

Thor, L. I972. Kulturminnesvårdens deltagande i den fysiska riksplaneringen I96972. In: Miliöer och större områden av betydelse för kulturminnesvården. Förarbete för fysisk riksplanering. Underlagsmaterial nr. 23 (Stencil). Pp. 7-ıо. Stockholm: Civildepartementet.

Unnerbäck, A. 1976. Vägledning för kulturhistorisk bebyggelseinventering. Rapport D I2. Stockholm: Riksantikvarieämbetet.

Unnerbäck, A. 2000. Historico-cultural evaluation - a necessary basis of the selection, care and documentation of historic buildings. In: Ballester, J. M. (Ed.). Sustained care of the cultural heritage against pollution. Cultural heritage No. 40. Pp. 29-37. Strasbourg: Council of Europe Publishing.

Unnerbäck, A. 2002. Kulturhistorisk värdering av bebyggelse. Stockholm: Riksantikvarieämbetet.

Unnerbäck, A. \& Nordin, E. I995. Kulturhistoriskt värde? Kulturmiliövård. Nr. I-2. Pp. II-2I.

Wallman, J. H. г 838. Öfversikt af svenska fornlemningar, med anvisning till deras kännedom och beskrifning. Kongl. Vitterhets Historie och Antiquitets Academiens Handlingar. D. I4. Pp. I-58. 
Weissglas, G., Paju, M., Westin, L. \& Danell, T. 2002. Kulturarvet som resurs för regional utveckling. En kunskapsöversyn. Rapport 2002:I. Stockholm: Riksantikvarieämbetet.

Verneideologi. NIKU-seminar 4. februar og 25. april 2002. 2003. Seip, E. (Ed.). NIKU Tema 5. Oslo: Norsk institutt för kulturminneforskning.

West, S. (Ed.). 20IO. Understanding heritage on practice. Manchester and New York: Manchester University Press.

Vestheim, G. 2008. All kulturpolitik er instrumentell. In: Beckman, S. \& Månsson, S. (Eds.) Kultursverige 2009. Problemanalys och statistik. Pp. 56-63. Linköping: SweCult.

Westin, H. 2005. Värderingsdiskussionen i teori och praktik. In: Alzén, A. \& Burell, B (Eds.) Otydligt. Otympligt. Otaligt. Det industriella kulturarvets utmaningar. Pp. 77-89. Stockholm: Carlsson Bokförlag.

Wetterberg, O. I992. Monument och miljö. Perspektiv på det tidiga I90o-talets byggnadsvård i Sverige. Göteborg: Inst. för arkitekturhistoria, Chalmers tekniska högskola.

Wright von, G. H. I990. Humanismen som livshålning. Stockholm: AB Rabén \& Sjögren Bokförlag.

Vägar till kulturarvet. Agenda kulturarv i Kalmar län. 2004. Länsstyrelsen Kalmar län \& Kalmar läns museum. (http://www.kalmarlansmuseum.se/site/projekt/ img/proj_agenda.pdf. (accessed on 2008-05-27))

Zachrisson, T. I997. Antikvariernas och andras landskap. In: Burström, M. et al. (Eds.) Fornlämningar och folkminnen. Pp. I2-59. Stockholm: Riksantikvarieämbetet.

\section{Unpublished sources}

Antikvarisk-topografiska arkivet (ATA), Riksantikvarieämbetet, Stockholm

"Plan till förnyad författning om Antiquiteter wård", vol. 3, serie FIV, Äa 2.

"PM г0.3 I 828", vol. 6, serie Fid. Götiska förbundets \& Jacob Adlerbeths arkiv (GF\&JAA).

"PM den 26 november I 827", Vol. 6. Götiska förbundets \& Jacob Adlerbeths arkiv.

"Motiver för Kongl. Witterhets. Hist. o. Ant. Akademiens förslag till ny Kongl. Förordning om fornlämningars fredande och bevarande (I 859 )", FIV:3, Äa 2.

"Byggnadsvårdsåret I 975 ", F 3 b, Kulturhistoriska byrån.

"Ett kort utkast om Antiquiteternes upfinnande och Conservation i Rijket", Konceptböcker I666-I673, B I:I, Äa I. 


\section{THE GREAT MASTERPIECE}

\section{The Rök stone and its maker}

Ola Kyhlberg

\begin{abstract}
The author attempts a source critical and semantic revision of the traditional reading of the concluding lines 25 to 28 on the Rök stone in the province of Östergötland (Ög I 36). Guided by the placement of these lines in the text's narrative, the author tests the hypothesis that the writer's signature may be included in this sequence. Indeed, if this is the case, Sibbe is the master of the Rök stone, not Varin, and the giant mentioned in the text presumably alludes to the rune stone itself. The original place of the monument is also discussed in connection with the place-name Jättingstad.
\end{abstract}

Key words: the Rök stone, new interpretations, runemaster, lawspeaker, melodious recital

\section{INTRODUCTION}

The Rök stone (Ög I 36) is undoubtedly a remarkable monument, but above all it is a work of masterly skill. For centuries this rune stone has evoked the curiosity of people and been a scientific challenge to researchers. The inscription's literary content, linguistic form and syntax have all been studied astutely.

Gun Widmark has said that the initiator of the inscription must have been a key cultural personage, but in that case for whom was the stone created? Perhaps Varin did not carve this inscription for any particular reader but saw in the stone a kind of "robot" that could magically take his place and assume the role that had been his own (Widmark I997:I65f). Widmark emphasizes that it is symptomatic that the text's interpreters have reached widely differing conclusions in their respective holistic views of the text. While one scholar has read it as a legal 


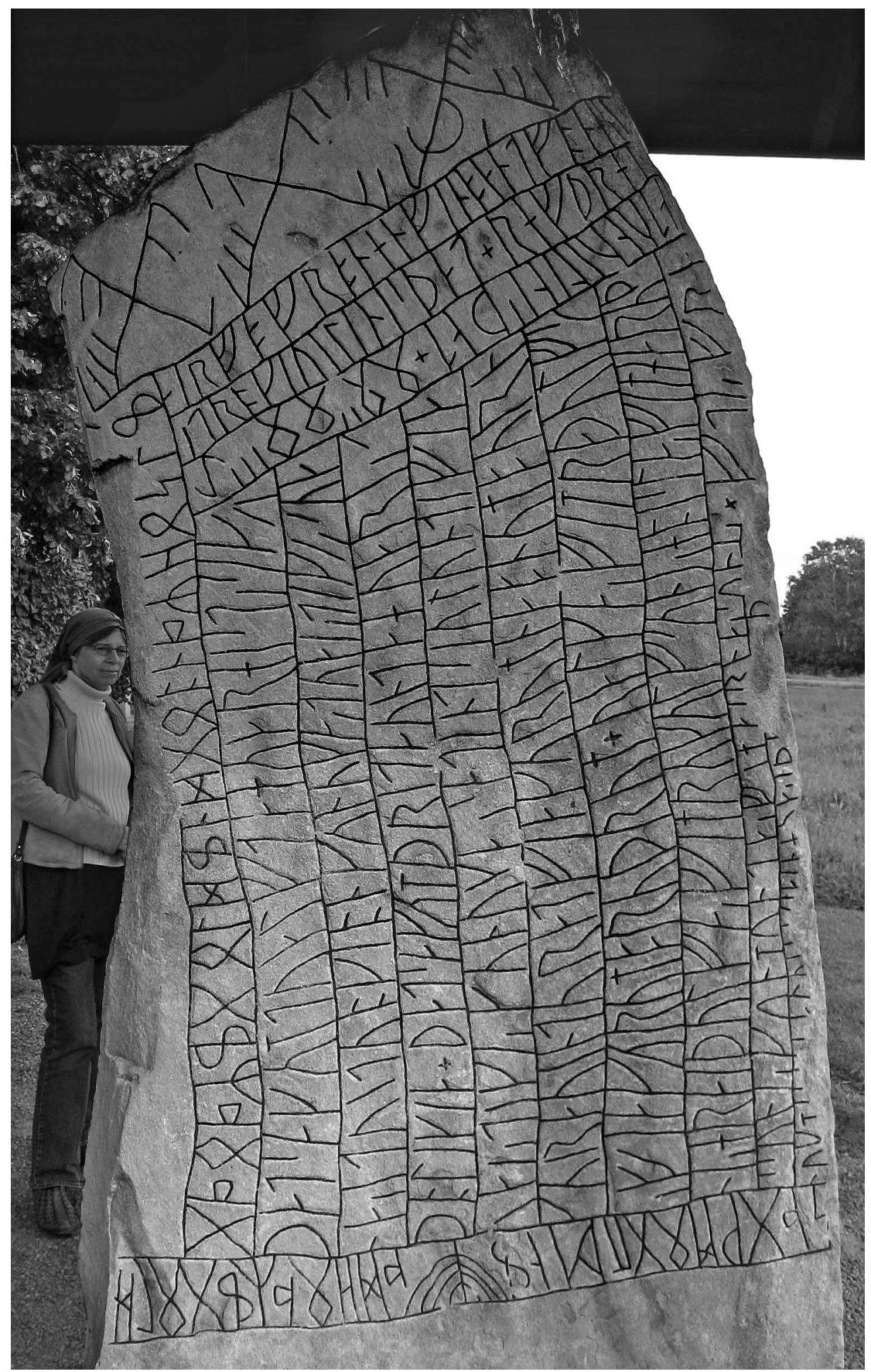

Fig I. The rune stone at Rök Church, Lysing hundred in Östergötland (Ög I 36). Photograph and computer revision by David Bruno. 
document, another has understood it as sprung from a genealogical poem and still others have basically seen it as a so-called greppaminne, constructed as a sequence of questions and answers (von Friesen I907; Wessén 1958; Lönnroth I977:77ff; Gustavson I991; Widmark I993, I997:I70; Grønvik 2003; Arwill-Nordbladh 2007).

A scholar who has recently addressed the complex problem of interpreting the inscription is Bo Ralph. He states that contemporary researchers generally agree on the reading of the individual runic letters and that the main discussion concerns the text's deeper meaning. He points out contradictions, questions elaborate explanations and, on certain points, also the text's wording and meaning (Ralph 2007:I23f, I $34 \mathrm{ff}$ ).

A number of specific problems and questions are discussed in this paper, such as:

- Who was actually the maker of the stone and its inscription?

- Who or what was in fact the giant mentioned in the text?

- What mode of presentation could be imagined for the Rök stone's epic?

- What was the original place of the monument?

\section{THE SCALDS}

In an early article, Otto von Friesen has given the following inspired characterization of the maker of the Rök stone (von Friesen I 907:I 5; Andersson 2006:3):

... with proud self-esteem has shown ... the depth and extensive knowledge he had in ancient and contemporary runic composition ... He has ... wanted to give an overview of the many ancient poems and tales he had in his repertoire. He was a scald, in the original meaning of this word: teller of tales and reciter.

The poem Beowulf includes the characterization of a prominent scald (Beowulf: A Verse Translation, I973: verses 868-874, p. 78):

... whose head was a storehouse of the storied verse, whose tongue gave gold to the language of the treasured repertory, wrought a new lay made in the measure. The man struck up, found the phrase, framed rightly the deed of Beowulf, drove the tale, rang wordchanges 
In early research the Iron Age scald was often seen as a kind of poet of temporary nature, but in the scald's activities lay the task of a historian of considerably higher dignity.

In Olav den heliges saga, Olav Haraldsson ( $\mathrm{d}$. AD I030) tells that a couple of the king's Islandic scalds, his court poets, often sat on a bench across from the king in the great hall and spoke freely but not without respect. This seating was considered the most honorable, above all during drinking ceremonies. That the explanation behind the social self-image of the scalds lay in their task as historian and chronicler can be understood from the story of the Battle of Stiklastad in the same saga (Heimskringla. Transl. with introduction and notes by L.M. Hollander, 1964:496):

... when King Olav had rallied his men, he assigned men to create a protective shield that would surround him during the battle ... He then called for his scalds and said to them ... "You must be here to see what happens ... In that way it will not be others who will tell tales and write poetry about it later."

More advanced scalds possessed a linguistic and literary dexterity whose esthetics can be compared to the high level of metalworking during the period. In his iconographic study of rune stones, Anders Andrén has pointed out that the art historian Sven Söderberg, already a century ago, in reference to Háttatal, argued that poetry and animal art were analogous (Snorre's Edda ... I95 8:22ff; Söderberg I905; Andrén 2000:II, 26):

The similarity between animal art and scaldic poetry instead speaks in favour of some kind of relevance for the different styles. They can be regarded as visual stanzas or visual metres by analogy with the metric forms of scaldic poetry that are described by Snorri in his Háttatal.

It is very clear from Háttatal that it was a literary virtue, formally as well as with respect to syntax and semantics, to create ambiguities and diversities. Háttatal is introduced with a description of the kind of verse known as drottkvatt 'court meter', followed by a description of the scaldic poetic style and of the distinction between stuðningar 'supporting or specifying first element in a true kenning', kenningar 'kennings', sannkenningar 'true kennings', and nygörningar, nýgervingar 'new creations'. 
Thereafter follow the important metrical and other liberties, leyfi, including the following nine (Snorre's Edda ... I95 8:2ff; see Meissner I92I after Ralph 2007:I33):

- enjambment álag

- whole assonance instead of half-assonance in odd lines

- combination of two syllables to one

- change in tense in a half-strophe

- two words with assonance beginning with the same consonant

- repetition of the same expression in both of the strophe halves

- repetition of verses or part of a verse

- repetition of small words in the same half-strophe that can cause obscurity or misunderstanding

- inclusion of parentheses that break up the phrase context

Although researchers have had great respect for the Rök stone's scald, the consequences of this do not seem to have been considered by formulating concrete expectations or hypotheses concerning the possible appearance of literary-poetic artistic tricks. Against the background of the poetic rule of Háttatal, it could be expected that certain choices of words were steered by poetic demands, such as assonance, alliteration, rhythm, intonation and melody, more than by the narrative's demands for semantic clarity (Björn Collinder's introduction to Snorre's Edda ... I 958:23). Poetic elegance may thus have been chosen before semantic clarity, but in research semantics seems to have taken a back seat to accidence and syntax, and semiotics is overshadowed by iconology.

\section{STRUCTURE OF THE TEXT}

The maker of the monument, its gorningisman - a term used in early provincial Swedish laws for craftsman, but appearing in the Icelandic literature as gerningamað $r$ for magician/sorcerer/wizard - was a bearer of literary tradition on the highest level. The "flowing hand" of his work consequently shows that he knew how to use the majority of different literary or poetic rules and artistic tricks (Jansson 1977:32ff; Ralph 2007:I24f and references cited therein; Arwill-Nordbladh 2007:58). Both a 24-rune futhark and a I6-rune futhark, as well as short-twig runes (Sw. kortkvistrunor), numerical ciphers (Sw. talchiffer), cryptic transpositional ciphers (Sw. förskjutningschiffer) and secret runes (Sw. lönnrunor), in addition to riddles and other kinds of illusionism 


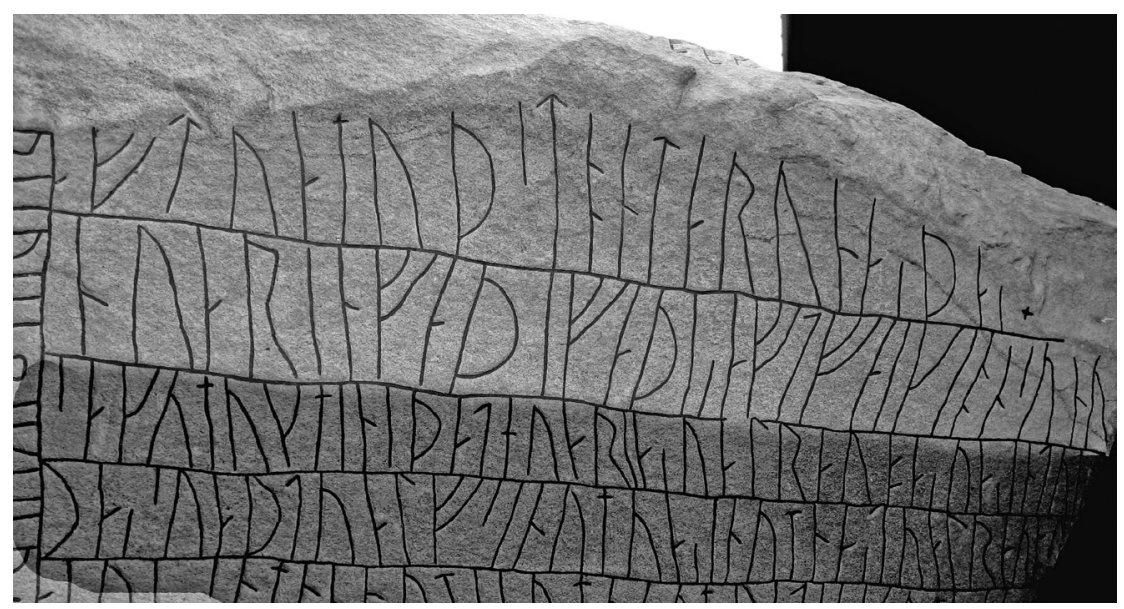

Fig 2. The Rök stone's dedication.

Photograph by David Bruno.

including what is probably an anagram, were all part of his "tool kit".

He excelled in his command of the carved rock faces in an architectural spirit, and he carved the inscription with nearly calligraphic ambition. Nothing seems to have been left to chance, and there are few clear mistakes, if any.

The text can be divided into three, mutually distinctive sections. The first section $(\mathrm{A})$ is the short introductory dedication including lines I and 2. This is followed by the sizeable epic and mystical main section (B) including lines 3 to 25 . The third and closing section $(\mathrm{C})$ includes lines 25 through 28 , beginning with the reference to the poet/rune-master in line 25 (Gustavson I99I:2 Iff). Thorsten Andersson has reflected on the size of the runes in the dedication, where the text band is approximately 25 to $30 \%$ taller/wider than average, something which he deems as linguistically meaningful and comparable to the dominating position of the secret runes on the back face of the stone (Andersson 2006 and below).

\section{Text section A}

Lines I and 2 compose the introductory phrase with the dedication to Vämod, formulated as if it were in the words of Varin, the father (Jansson I987:I32; Gustavson I99I:I4ff):

... Aft Vamod standa runaR paR. Æn Varinn faði, faðiR, aft faigjan sunu ... 
(In memory of Vämod stand these runes. And Varin wrote them, the father, in memory of his dead son)

The dedication has always been interpreted as that Varin was the rune carver. This is probably partly because there has been no evaluation of to what degree the choice of words in these lines can have been steered by poetic demands.

The basic form of the verb faði is fa meaning to paint, write/work/ make, cut. Hávamál mentions runes “... made by mighty gods, known to holy hosts, and dyed deep red by Óthin ... runes and powerful signs ... which that dyed the dread god ..." and "thus I write and the runes I stain ..." (The Poetic Edda. English transl. by L. M. Hollander, I 962:26ff). In these citations the coloring of the runic letters is partly linked to "Óðin", partly to "the dread god" and partly to the "powers". Thus a distinction is made between the verbs dye/stain, make, and write with a powerful reference to the divine aspect of the runes themselves as well as to the knowledge of runes (Den poetiska Eddan ... I972:61, 70, 72; Jansson I977:I 59ff and references cited therein). It probably can be understood that the meaning of the verb fa can not be translated automatically as 'cut', and the coloring of runic letters and signs has had particular magical meaning which is something other than the magic of the cutting and carving itself.

The stem of the word faigjan also appears in Guta Saga in the sentence "Mik witin ir nu faigastan oc fallastan", in which a man tells how he fears for his life, going as a negotiator to the king of the Svear (Holmbäck \& Wessén I979:292, 306; Photo in Kyhlberg I99I:I23).

The new reading and interpretation of the concluding text section $\mathrm{C}$, as presented below, is also indirectly important to the interpretation of these introductory lines.

\section{Text section $B$}

Line 3 through letter 6 of line 24 . Following the introduction, the monument itself takes on the role of narrator in the verb sagu(m) which has the fundamental meaning of saga 'tell' and which semantically is closely related to the concept of saga in such words as domsaga 'judicial circuit' (Wessén 1958:76; Widmark 1997:I67ff and references cited therein).

This form of ingress is probably comparable to the formulation in Voluspá, "I ask for hearing from all", which also appears in the Icelandic sagas when someone wishes to perform a recitation or song (The 
Poetic Edda ... Ed. by Ursula Dronke 1997:7; Gustavson I99I:2 Iff). This is discussed below.

In addition, this text section mainly includes parts of narratives that possibly may be explained as excerpts from an original erfidrápa or erfikvoeði. The scalds' presentations of such elegiac memorial poems seem more or less to have been an institutionalized part of the burial ceremony erfi (Heimskringla. Transl. with introduction and notes by L.M. Hollander, I964:I24f; Hallberg I993:5 If; Sävborg I997:I77, note 2 I 5; Sundqvist 2002a: I 70ff, 276f, note I 22).

\section{Text section $C$}

The part extending from letter 7 of line 24 through line 28 has been deciphered and interpreted in widely diverging ways.

Its traditional reading, characterized by Widmark as speculative and linguistically not particularly convincing, is (Jansson I987:34; Gustavson I991:23; Widmark I997:I68ff):

... uilin is pat. knua knatti/i/atun. uilin is pat. nit. sagu $/ \mathrm{m} / \mathrm{mug}$ minni. porr. sibi uiauari ul nirupr ...

The alliteration, assonance and swaying iambic intonation of the text all throw light on the poetic qualities of the text, but simultaneously somewhat hide its meaning, which was an intentional poetic effect according to Háttatal, see below.

Already in lines 2I-22 in the sequence ... hvar Inguldinga vari guldinn ..., the scald's brilliance is declared (Wessén 1958:25; Andersson 2006:I; Ralph 2007:I25). Regarding assonance and alliteration in the sequence ... knua knatti/i/atun ..., the title of a modern children's film, "Klaga lagom Alfons Å berg" ("Happy Alfie Atkins") by Gunilla Bergström may be offered as an analogy, representing a living poetic practice.

\section{Reading order}

The different categories of letters and signs are principally kept together, with one exception: the last letter of line 25 , a single secret rune (Sw. lönnruna) of the kind found in I9 instances in the following line 26. Since the scald otherwise does not mix short-twig runes, numerical ciphers, cryptic transpositional ciphers and secret runes, this isolated instance undoubtedly must be understood as a practical instruction to the reader! Without this support it would be very difficult to identify 
the continuation of the text on the narrow side of the stone. This single secret rune should most probably be linked to its typologically comparable letters in line 26 on the narrow side of the stone, which thus should be read from the base of the monument upwards.

In consequence the traditional reading order must be changed, and therefore also the reading. This means that the secret runes should be read as III $/ 3 /$ not III/ $/ 2 /, \mathrm{III} / 3$ and III/ $/ 5$, which are the runes $\mathrm{b} \mathbf{p}$ and $\mathrm{R}$, respectively. Combined with ni in line 25 , this seems to become ... nippR (?) This doubling of the runic letter $\mathbf{b}$ may perhaps be explained as the result of some kind of confusion ( $c f$. Lagman I989:33f).

\section{"HE COULD CRUSH A GIANT" (?)}

The traditional interpretation of the sequence ... / uilin is pat/knua $\mathrm{knatti} / \mathrm{i} /$ atun/uilin is pat/... in lines 24 and 25 has become, in romantic spirit, approximately "he could crush/beat a giant /to death/". In contrast Joseph Harris maintained, similarly to Lars Lönnroth, that iatun 'the giant' was the subject and consequently it meant that a giant had killed a man named Vilinn/vélinn. These interpretations are somewhat problematic, as is Widmark's interpretation that the verb knua expresses the giant's sexual activity and not Thor's rough treatment of him with his fists (Widmark 1993:32; Harris 2007:82 after Elmevik 2008:I 7 f).

The word iatun begins line 25 and is written with common runic letters, while ... knua knatti ... at the end of line 24 , the preceding line, is written with transpositional ciphers. This sequence crowns the work, both literally and figuratively, and is situated in a place at the end of the text where it is common in Viking Age runic inscriptions to find the carver's signature.

A key to a new reading of the text could be if one works from the idea that the word iatun should not be understood naturalistically in the sense of referring to just any mystical giant, but instead understood as being a heiti for the monument itself, the giant stone! Besides, in lines I 2-I 3 a heiti also appears in the phrase "where the horse of Gunn (i.e. steed of the Valkyrie, the wolf) sees food on the battlefield" (Jansson I987:33; Gustavson I991:25).

As a consequence of such a reinterpretation there could also be a minor change in the meaning of the verb knua. It still should be understood as firm and powerful, but not to 'crush/beat someone to death', but to 'crush/beat', 'slash out at something'. The verb knua stems from 
the Old West Norse noun knúi, Old Swedish knôe 'knoge', to which the Swedish and Norwegian verb knusa and the Danish knuse 'break apart', 'crush' also belong. In an article from 2008, Lennart Elmevik cites Norrøn ordbok, partly regarding the Old West Norse, Icelandic term knoka 'hit with one's knuckles' and partly concerning the Old West Norse, Icelandic term knosa, etc. (Elmevik 2008:20). Such a meaning of the verb in the Rök stone's text is not possible to establish using any direct parallel, but this suggestion of a new interpretation is supported partly by the close relationship to the modern noun ' $k n o g e$ ' and partly by the fact that mystification, according to Háttatal, had poetic value in its own right.

The overall result of this is that it is not Varin at all who has written the runes and created the monument at Rök, but instead Sibbe!

\section{"VILIN IS PAT" (?)}

Flanking the words ... knua knatti/i/atun ... in lines 24 and 25 is the consequently doubled wording of ... uilin is pat ... Earlier, this has been understood as somewhat disconnected and without clear context, but considering the background of the "craftsman/sorcerer's profile" and with regard to its placement in the concluding text section $\mathrm{C}$ it could be taken as being included in the signature of the writer.

The word uilin traditionally has been interpreted as a heiti for the god Oden, as the name of an unknown (!) son of the god Thor, or as the phrase "Do you wish". Widmark disagrees with Elias Wessén's reading "Vilen it is" and argues instead that it should be read as "Vilen he is", which idiomatically may be expressed as "He is Vilen". It may be noted that Wessén, according to Widmark, probably rejected the last alternative because he had difficulty putting it into a reasonable context (Wessén 1958; Widmark 1997:I68f; Sundqvist 2002a:I64).

Recently, Elmevik published an article where he presented convincing arguments in support of the idea that uilin should be a man's name, identical with the Old Norse adjective vélinn, Old Swedish *velin 'knowledgeable in magic/sorcery' (Elmevik 2008:20). The name therefore may be understood as a nickname '[one who is] knowledgeable in sorcery', which in this context logically could be understood as 'runemagician' and the whole phrase ... uilin is pat ... as a commentary on Sibbe's great literary brilliance.

The formulation by von Frisen, "The deep and extensive knowledge he had in ancient and contemporary rune usage", should have included 


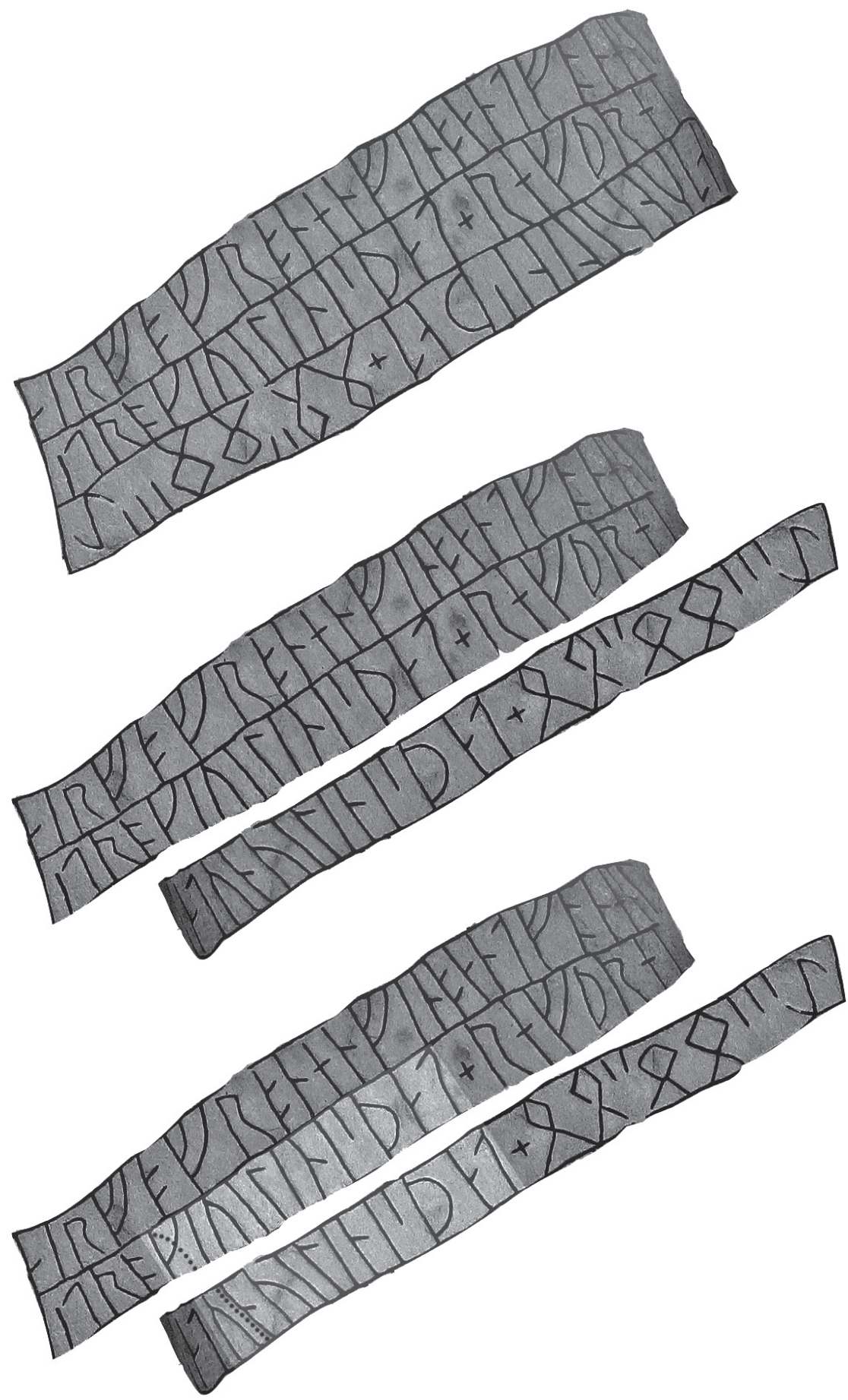

Fig 3 A-C. Lines $23-25$ of the Rök stone along with an analysis and attempt at interpretation. Photograph and computer revision by David Bruno. 
a large measure of magic and sorcery (von Friesen 1907). One may recall the duplicity in the meaning of gerningamadr/gcerningisman which in its earlier form in the Icelandic literature meant 'magician/wizard/ sorcerer' and which in its later form in medieval provincial law had been watered down to mean 'craftsman'. Regarding Sibbe's literary dexterity we may take it that he was seen by his contemporaries as a true 'rune-magician' (Price 2002: I I Iff).

\section{*Vivil (?)}

According to Per Vikstrand the term for cult-functionary, "vivil, may be a diminutive form of the word that forms the basis for the personal name WiwaR. It was not borne by any particular chief or leader, but by someone in this person's sphere. (Hellberg I 979:I6I with note 97; Gustavson I99I:20; Vikstrand 200I:393f; Sundqvist 2002a:I64; Palm 2004:35).

The word uilin in the phrase ... knuaknatti/i/atunuilinispat ... associatively may lead one's thoughts to the term for cult-functionary *vivil, but then how should the missing introductory syllable $v i$ - be understood? The answer may lie in poetical freedom where, according to Háttatal, two syllables could be combined to make one. An example of this kind of illusionism is illustrated in how the main syllable of the words aft and $\boldsymbol{x n}$ in lines I and 2, respectively, coincides with the outer line of the vertical text band (see Fig. 2), and ... knatt/i/iatun ... already shares the letter I. In speculation therefore, the missing syllable could have been an attempt to mystify. If only the $\mathbf{n}$ - rune's secondary sign in the word iatun is neglected (painted?), the main letter may be read as an I-rune. Thus, the word "vivil appears. The same word might be read in the previous line if the k-rune in the word troki 'dräng' (follower?) is changed to a u-rune with the help of an imagined (or painted?) line (von Friesen I920:63f). But this is only speculations.

Elisabeth Arwill-Nordbladh has understood the original surface of the stone as being light and clean (Arwill-Nordbladh 2007:59), but the shade of its present color can definitely be compared to the eroded surface of the often whitish-gray antique marble sculptures and architecture or the natural wood of many medieval church sculptures. All of these objects were originally brightly colored.

\section{*VIAVARI}

In a study from 2006, Thorsten Andersson placed great value on the dominating position of the secret writing on the back face of the stone, 
which in his opinion had not been given enough attention (Andersson 2006:2f):

... it may be a secretive message, about the desire to keep secret, excel, entertain, or test the acumen of the reader or perhaps about magic.

As evidence of this foresight, in 2007 Ralph presented an alternative reading and interpretation of the conclusive phrase ... sibi uiauari ul nirupR ... According to him, this sequence is an anagram (Ralph 2007:I4 I with reference to Grønvik 2003)! In this case Sibbe would have constructed an anagram that included his own name and then placed it where it could literally and figuratively crown the entire work!

Using the linguistic demands of the anagram, Ralph's suggestion actually may be able to explain the problem with the duplicated appearance of two such closely formulated epithet/titles as *vivil and *viavari.

Olof Sundqvist has shown that *viavari is semantically comparable to "vés vq̨ðr, "vqrðr vestals 'protector of the temple's altar' which is nothing less than an epithet for the ruler of the Svear in Ynglingatal, along with *vévorpr which appears in other places including, most likely, on the Sparlösa stone in the province of Västergötland. Gustavson compares this linguistically with a medieval Swedish word for churchwarden: kirkioväriande /appr./ (Sundqvist I998; Gustavson I991:I3;Vikstrand 200I:396). In Scandinavian written sources, Norwegian rulers appear as wardens of sanctuaries or holy-mythological places, and in Hákonarmál it is stated in particular that the king is praised for having watched over holy places (Sundqvist 2002a:200, 28I). Vita Ansgarii mentions how Ansgar met a person who claimed to have participated in the holy-mythological congregation that was seen as ruling over the land, and who had now been sent out to spread a message (Boken om Ansgar ... I 986:52f). This cult functionary ought to have been a *viavari.

The inscription on the Oklundahällen stone in Östra Husby parish, Östergötland, mentions a man who had committed a crime (manslaughter?) and then gone to that $v i$ 'sanctuary' where he obviously effected a reconciliation (gained legal immunity?) which was attested by someone named Vi-Finn. A parallel to this name, in the form of $V i$ Gullela, is inscribed on a bowl from the silver hoard from Old Uppsala, dated at the earliest to the late eleventh century AD (Winkler 2008). The still existing Swedish expression varg i veum 'outlawed criminal' bears 
witness to peace and asylum in the sanctuary, and refers to the harshest form of outlawry for anyone who committed an offense against a sanctuary (Vikstrand 200I:324f).

On the Rök stone, it is Sibbe who is linked to the epithet *viavari. Departing from Sundqvist's explanation of the word it is suggested that this refers not only to a cult leader, but also to a position as lawspeaker or judge (Jansson I977:40; Salberger I980:19; Norr 1998:93, I94; Sundqvist 2002a: I96ff with notes, I 59, I96f; Strid 2005: I 5 of, and literature cited therein, $c f$. Widmark I997:I7 If). This would be a completely acceptable explanation to his unique literary competence and literary education as well as his power of creating characters, and it would give a satisfactory answer to Arwill-Nordbladh's key question of how the scald was able to produce such an exquisite written document without any known prototype (Arwill-Nordbladh 2007:59).

As Anders Andrén has mentioned in a seminar, the question of Varin's and Vämod's respective social positions then arises. Supported by the hypothesis that Sibbe was a lawspeaker or judge, Varin should have been a regional sovereign and the monument been initiated by the legitimacy crisis which occurred with the death of his heir, Vämod.

It is probably such a situation that is reflected in the epic part of the inscription. In text section B, the speaker,pulen (?), turns to the family myths, that is, the forefathers, which ought to be an expression of legitimacy.

\section{"NINETY-YEAR OLD BEGOT" (?)}

The word nirupR 'ninety-year-old' actualizes the question of praxis regarding the designation of age. According to Andreas Nordberg, an inclusive way of calculating was used in ancient times, and Göran Henriksson has opposed the interpretation 'every ninth year' in the expression post novem annos since the first year is reckoned from the first day of the year and not from the last as is done today (Henriksson I995:34I; Nordberg 2006; Sundqvist 2007:I39; note I4O). Consequently, a word such as nirupR should be understood as if, in fact, Sibbe was in his eighties, not his nineties ( $c$ f. Wessén I95 8:54; Andersson 2006: I, 5f; Arwill-Nordbladh 2007:59). A person can be expected to be considerably more vital at 80 than at 90 years of age.

The verb ala /el, ól, alinn/ in ... sibi uiauari ui nirupR ... in line (27-) 28 in text section $\mathrm{C}$ traditionally has been read as avla 'beget'. Some researchers thereby have taken the liberty of supplying the noun 'a son': "Sibbe of Vi, ninety years of age, begot /a son" (Jansson I987:36), a 
speculation which is not reasonable with regard to the narrative's precision in other respects.

A shift in meaning of the verb ala may be the key to a reinterpretation.

In Old West Norse the verb ala meant avla 'beget, father' and föda 'give birth, mother', föda till världen 'bring into the world', föda och uppföda 'give birth and nourish'. In poetic language the verb has the additional meaning of 'being animated or ruled by' (Jónsson, F. (Ed.) I93 I:5; Fritzner I883-96/I954/:26ff). In medieval prose the verb still had similar meanings: avla, föda, föda upp, upprätthålla 'beget, give birth, nourish, maintain' and utöva något över någon 'exercise something over someone' (Ordbog over det norrøne prosasprog I, I 995:spalt 250-252). Judging from the context, the scald's use of the particular verb ala probably should be understood as having been intentionally chosen for its obvious, powerful, fundamental meaning of avla, föda, so as to confidently say that by this action, inscription and narrative he gave life to this giant stone. The hypothetical question then is whether or not the verb's basic meaning could be taken as semantically close to the verb koncipiera, befrukta, fá idé till 'conceive, inspire/ stimulate, have an idea for' (Nationalencyklopedien, Bd I I, I 993:228).

In the framework of the 'craftsman's profile' as sketched above, it would seem to be completely natural that, in his contemporary and social environment, the surely greatly respected and highly esteemed Sibbe wanted to point out, not least to future generations, that despite his considerable age he was able to carve and form this giant block of rock, and in doing so he created this remarkable written monument.

A main result of this study is the following suggestion for a revised reading and idiomatic interpretation of text section C (cf. Gustavson I99I):

\begin{tabular}{|c|c|c|}
\hline Inscription & Prevalent translation & Idiomatic interpretation \\
\hline$\ldots$ uilin is bat & Vilen is it & "The rune-magician" is it \\
\hline knua knatti/i/atun & He could crush a giant & He could carve the giant /stone/ \\
\hline uilin is pat & Vilen is it & "The rune-magician" is it \\
\hline sagu/m/mugminni & $\begin{array}{l}\text { We tell the kinsmen's tale/ } \\
\text { I tell the young ones }\end{array}$ & $\begin{array}{l}\text { I tell the young ones/ } \\
\text { I tell the ancient tale }\end{array}$ \\
\hline (?nip/p/R?) & (TOR. Nit) & \\
\hline sibi uiauari & $\begin{array}{l}\text { Sibbe } \\
\text { watchman of the sanctuary }\end{array}$ & $\begin{array}{l}\text { Sibbe } \\
\text { watchman of the sanctuaries }\end{array}$ \\
\hline ul nirupr ... & $\begin{array}{l}\text { ninety years of age } \\
\text { begot [a son] }\end{array}$ & $\begin{array}{l}\text { eighty years of age } \\
\text { created }\end{array}$ \\
\hline
\end{tabular}




\section{MODE OF PRESENTATION}

What mode of presentation could be imagined for the Rök stone's epic: story-telling, speech or recitation, or something else?

Similarly to Stefan Brink, Sundqvist gives a picture of the scald who recites in the hall, pointing out that the poetry, with respect to the semantics in the word $p u l$, should have been presented in a kind of mumbling voice. Etymologically, Brink combines the word $p u l$ with 'speak', 'ramble' (rhymes), and probably also 'sing' (Brink 2003:79; Sundqvist 2002a:2 Iof; 2007:35f). To a certain extent, such a conclusion may be analogized with Britt Solli's idea about a connection between pulen and the Sami naid 'shaman' since the latter, among other things, is presented as being both a notable story-teller and a speaker-singer (Price 2002:259f; Solli 2004:263,27I).

Widmark and others have pointed out that the narrative tradition clearly needed a person who was responsible for preserving the ancient tales, a minnuga man who was responsible for memorizing and passing along important traditions, narratives and myths. In von Friesen's formulation, above, the Rök stone's scald more than anyone else can be said to be worthy of the title pul, which possibly was the name of a role the scald played in certain ceremonial or traditional contexts (Wessén I958:76; Widmark I997:167ff. and literature cited therein; Arwill-Nordbladh 2007:58).

A number of strophes/verses begin with the repetitive Jag säger 'I speak/say/tell' and a simultaneous varied epic, which is characteristic of, for example, medieval ballads ( $c f$. Jansson I999:2 I 2). Along with the text's rhythmical poetics this gives indications that the Rök stone's epic should not be understood as meant for traditional reading - or for reading aloud - but for the specialized form of interpretation that makes use of linguistic rhythm, intonation and melody: melodious recital.

A formulation in "The Plaint of Oddrún" in The Poetic Edda may be interpreted in this manner (The Poetic Edda. Vol. II. Mythological Poems. Ed. ... by U. Dronke 1997:284):

... his harp I heard ... how the strings he struck, bestead full sore.

An indication of similar kind is given in the Beowulf poem (Beowulf. Transl. by M.Alexander, I973:I I 7; Sundqvist 2002a:I7 I, 2002b:I43): 
... the daring-in-battle would address the harp, the joy-wood, delighting; or deliver a reckoning both true and sad; or he would tell us the story of some wonderful adventure, valiant-hearted king.

Against such a background, the soft-sounding lyres with relatively distinct tones, such as those deposited in the burial boat at Sutton Hoo in the 620 s AD, have their natural explanation: an instrument that would support the pulse or rhythm of the presentation with some kind of ringing "inter-punctuation" consisting of whole or broken chords. Similar lyres were also deposited in the grave at Taplow around AD 600, the grave at Prittlewell in the 6oos AD, in the graves at Bergh Apton, and in Severinus Church in Cologne. They are also represented by the bronze bridge for six strings from Gerete, Fardhem parish, Gotland (SHM 34689), which Martin Rundkvist brought to my attention; the amber bridge for four strings from Broa, Halla parish, Gotland (SHM I0796); and the elk-horn bridge for five strings from Birka (SHM 5208:I634) (Bruce-Mitford I979:44ff; Tegnér I980; Gustafsson \& Vedin 2007:I97ff). The bronze bridge from Gerete is equipped with a thin bronze thread to secure the strings, which shows that the movement from their vibrations must have been very slight. The bridge from Broa was about I $5 \%$ higher and the bridge from Birka almost $70 \%$ higher than the one from Gerete.

Such string instruments definitely were not melodious, but were best used as a chiming support to an oral recitation - a melodrama. Altogether this may be used as a basis for the assumption that $p u l$ was a particular kind of story-teller or singer who used melodious recital as an interpretative form of expression.

\section{*RÖKSTAD (?)}

Where was the original place of the monument? Previous research has seen the earliest evidence for the parish name, de Røskyrc, from the year AD I2O2 as a direct reference to rauken, which means more or less 'the standing/raised stone' (Gustavson I99I:3). In some respects this seems to be a rather far-fetched explanation.

Something that looks intentional is the unidentified place-name with the prefix Rök-found among the oldest lands donated to the monastery Vreta kloster, which like the Rök stone is located in the province of Östergötland. Around the year AD I I70, a woman named Æstrid 
gave her daughter a dowry in the form of lands in Granstad, Tjällmo parish, and in *Rökstad (parish unknown). Other parishes appearing among the early land donations to the monastery are Slaka, close to Linköping, and Kimstad, close to Norrköping. As presented by Alf Ericsson in his cartographic account of donations to the monastery prior to the year I I 70 or so, a certain argument may be made for the location of this "Rökstad in Lysing hundred (Ahnlund I 945:3 I 8f; Gillingstam I948:26f; Ericsson 2007:I07ff; Fig. 38 and Tab.3).

Like Heda and Kumla, Rök has no village connected to the church. However, in the draft of the land surveyor Anders Börjesson's (Gadd) map from I639-4I (Signum Ra Dioa:4 If) a deviating pattern of ownership can be seen in the structure of lands adjacent to the church and vicarage. This partly includes an abandoned field and partly a field belonging to Millingstorp, which is a hint that the church property may be a construction remaining from an earlier settlement unit that disappeared already in the seventeenth century - "Rökstad (?) (Andersson I963; Brink I990b:34f; Johansson I 990:72ff; Kennerstedt I990:I 27f).

Considering the earliest spelling of the parish name from $\mathrm{AD}_{\mathrm{I}} 2 \mathrm{O2}$, de Røskyrc, one should consider that the place-name Rök may be a reductive construction of the Old Swedish *Røk/stadha/kirkia and comparable to the Gotlandic parish name Stenkyrka, which originally could have referred to the village or estate named Stenstugu: *Sten/stugu/kirkia (Kyhlberg I 99I:I I 5). Thus it would be a semantic analogy with, for example, the parish name of Rogsta (about I34 I in Rochstadum) in Hälsingland, which according to Brink can be traced back to an obsolete village name with the terrain-related prefix *rok 'higher ground or hill' (Andersson I 963:95ff; Brink I 990a:326ff and references cited therein; I990b:34; Wahlberg, M. (Ed). 2003:257 and photo 57).

\section{JÄTTINGSTAD}

As a consequence of the above-suggested interpretation of iatun as a heit $i$ for the monument itself, focus shifts to the place-name Jättingstad ( $1399 j$ joetunngsxstadhom), which is mentioned on the rune stone Ög I 32 at Heda Church (Östergötlands runinskrifter I 9 I 5:I 26f, Pl.XLIII).

In reference to von Friesen, Elias Wessén has commented on the derivation of the somewhat problematic first element of the placename (Wessén I958:54 note 2; cf. Jättendal in Hälsingland according to Brink I990a:289f with note 6; Johansson I990:73): 
(... more likely) nickname of a person. But the possibility that a mystical local tale of some giant who thus gave the village its name is perhaps not out of the question.

Except for Kumla, of the churches near Lake Tåkern it is possibly only Heda Church that is surrounded by an area with ancient monuments (Broberg I990:Fig. 2; Brink I990b:34). Five villages are located at the western, southern and eastern peripheries of this area. Heda parish holds a unique position with respect to the distribution of ancient monuments, which shows a strong spatial relationship to the parish territory! This pattern of burial monuments along the east, southeast and south boundaries of the parish, together with the agglomeration of burial monuments and mounds at the site of the church, should therefore be interpreted as an expression of some kind of ownership structure, at the center of which is the site of the church. A similar picture is evident in the distribution of runic inscriptions (Broberg I990:Fig. 2; Palm I990:Fig. 6, App. I). Somewhat less than two kilometers southwest of Heda lies Tuna (I374 in tunum), and east-southeast, at slightly more than one kilometer, lies Disevi/d (Brink I990b:38). About two kilometers south-southwest of Heda and one kilometer farther south from Tuna lies Jättingstad. The village of Tjugby is about two kilometers east-northeast of Heda. The first element in the place-name Tjugby is probably a thiudh (Vikstrand 200I:87f), which possibly signals the place of a local or regional assembly, a thing. Andersson has analyzed the written sources concerning thing places and their spatial situation, and he has suggested that a Tingsmaden ( I 682 Tingzma) under Frösäng $\mathrm{I}^{\mathrm{I}}$ south-southeast of Disevi/d could be related to the fifteenth-century thing place *Haraker (Andersson I965:28 Iff; Gustavson I99I:II). Altogether this indicates that the Tuna-Heda-Jättingstad area has held some form of unique position within the region.

The position of the scald and rune-master Sibbe in the legal society may have been linked (indirectly?) to the stone's supposed spatial connection to thing places. A possible early central place and the primary spot for the Rök stone in the Tuna-Heda-Jättingstad area can perhaps be seen by these contextual indices.

In association with Heda Church, there are peasant stories from more recent time telling of a giant. Perhaps this mythical tale emanated from the large rune stone, which could well have been commonly referred to as "the giant". In such an explanatory context, the place-name 
Jättingstad may be imagined as representing an important location in the Rök stone's creation. According to praxis, the estate or village in this case was given its name after the monument had been removed.

The Rök stone's supposedly prominent position in common tradition could explain why in the Iron Age/Middle Ages it was moved to Rök, perhaps in connection with the establishment of a thing place and/or because of the construction of the church in the first half of the twelfth century.

\section{CONCLUSIONS AND EPILOGUE}

The incentive for the monument ought to have been when Varin, probably a regional sovereign or lord, lost the son who would have been his rightful heir according to the patrilineal legal system of the time.

Varin commissioned an erfidrápa from Sibbe, who bore the exclusive epithet *viavari 'watchman of the sanctuaries' and who probably was a law-man. Sibbe tells us that he succeeded in (the feat of) carving this giant-like piece of rock while in his eighties. He asserts his mastery as scald and rune carver by twice calling himself 'the knowledgeable sorcerer', or in this context most likely the 'rune-magician', and through his narratives addresses future generations.

Varin's commission of an elegiac memorial poem to his deceased son was carried out in such an artistic way that the result is just as much a monument to the rune-master's literary refinement, literary competence and power of creating characters as it is a memorial to Vämod Varinsson.

In his learned introduction to Snorre's Edda, Björn Collinder maintains that Snorre's intentions were to provide future generations with a handbook of ancient mythology, courtly language, and traditional scaldic poetry along with an account of the ancient stylistic metrical verse. The former, says Collinder, became Snorre's testimony (Snorre's Edda ... I958:I9ff). A similar value perspective may be applied to the Rök stone and its maker. From Sibbe and his masterpiece there seems to be - via Snorre and his Edda - a thread of conceptual history and history of ideas that extends to Olof Rudbeck (d. I702), his magnum opus Atlantican, and the grandiose Latin inscription on his gravestone in Uppsala Cathedral, which in free translation says that the gravestone shows his mortality while the Atlantican shows his immortality. 


\section{Acknowledgement}

I am very grateful to Phyllis Anderson Ambrosiani for her exquisite translation and to Pål Andersson, Anders Carlsson, Helmer Gustavson, Lena Johansson, Magnus Källström and Thorgunn Snaedal for advice and assistance. Last, but not least, I want to express my gratitude to David Bruno for producing the photographs. 


\section{References}

Ahnlund, N. 1945. Vreta klosters äldsta donatorer. Historisk tidskrift. Sextiosjätte årgången. Pp. 30I-35I.

Andersson, Th. I963. Sockennamnen Hedheskirkia 'Heda' och Røskirkia 'Rök'. Namn och bygd: tidskrift för Nordisk Ortnamnsforskning. Femtioförsta årgången. Pp. 95-I I9.

- 1965. Svenska häradsnamn. Nomina Germanica - Arkiv för germansk namnforskning I4. Lund: Sahlgren, J. (Ed).

- 2006. Varin och Vamod - och Sibbe. In: Peterson, L., Strandberg, S. \& Williams, H. (Eds). Namn och runor: uppsalastudier i onomastik och runologi till Lennart Elmevik på 70 -årsdagen 2 februari 2006. Namn och samhälle I7. Pp. I-8. Uppsala.

Andrén, A. 2000. Re-reading Embodied Texts - an Interpretation of Rune-stones. In: Burström, M. \& Carlsson, A. (Eds). Current Swedish Archæeology 8. Pp. 7-32. Stockholm: The Swedish Archaeological Society.

Arwill-Nordbladh, E. 2007. Memory and Material Culture - the Rune-stone at Rök. In: Fransson, U. \& Svedin, M. \& Bergerbrant, S. \& Androshchuk, F.(Eds). Cultural interaction between east and west. Archaeology, artefacts and human contacts in northern Europe. Stockholm Studies in Archaeology 44. Pp. 56-60. Stockholm.

Beowulf: A Verse Translation. Alexander, M. (Trans.). Penguin Classics. Great Britain 1973 .

Boken om Ansgar. Rimbert: Ansgars liv. Översatt av Eva Odelman. Med kommentarer av A. Ekenberg, C. F. Hallencreutz, S. Helander, A. Härdelin \& E. Odelman. 1986. Stockholm: Proprius.

Brink, S. I990a. Sockenbildning och sockennamn. Studier i äldre territoriell indelning $i$ Norden. Vol. LVII. Studier till en svensk ortnamnsatlas I4. Andersson, Th. (Ed). Uppsala: Acta Academiæ Regiæ Gustavi Adolphi.

- I990b. Tåkernbygden. En bosättningsonomastisk studie. In: Dahlbäck. G. (Ed). I Heliga Birgittas trakter. Nitton uppsatser om medeltida sambälle och kultur $i$ Östergötland "västanstång". Pp.29-55. HSFR. Stockholm.

-2003 . Den förkristna muntliga kulturen i Norden: till frågan om det kollektiva minnet. Saga och Sed. Kungl. Gustav Adolfs akademiens årsbok. Pp. 7 I-8I. Uppsala.

Broberg, A. I990. Tåkernbygden. En arkeologisk bebyggelseanalys. In: Dahlbäck. G. (Ed.). I Heliga Birgittas trakter. Nitton uppsatser om medeltida sambälle och kultur i Östergötland "västanstång”. Pp. I I-27. HSFR. Stockholm.

Bruce-Mitford, R. 1979. The Sutton Hoo Ship Burial. A Handbook. 3rd ed. London: British Museum.

Den poetiska Eddan. Översättning av Björn Collinder. 3 rd ed. 1972. Uddevalla: Forum.

Elmevik, L. 2008. Runföljden uilinspat på Rökstenen. In: Wahlberg, M. \& Leibring, K. \& Nyström, S. (Eds). Ortnamnssällskapets i Uppsala årsskrift. Pp. I 5-23. Uppsala.

Ericsson, A. 2007. Attungen - ett medeltida fastighetsmått. En agrarhistorisk undersökning baserad på attungsbelägg i SDhk till år 1376 och Folke Dovrings kasuistik. Uppsala, Swedish University of Agricultural Sciences:Licentiate thesis.

von Friesen, O. I907. Rökstenen. Svenska Turistföreningens årsskrift I906. Pp. 42-55. Stockholm. 
- I920. Rökstenen: runstenen vid Röks kyrka Lysings härad Östergötland / läst och tydd av Otto von Friesen. Stockholm.

Fritzner, J. I 883-96. Ordbog over Det gamle norske Sprog. In: Arup S.D. \& Knudsen T. (Eds). Ordbog over Det gamle norske Sprog. Nytt uforandret opptryck av 2. udgave med et bind tillaegg og rettelser 1954 . Oslo: Den norske forlagsforening.

Gillingstam, H. I948. Ett nytt bidrag till kunskapen om Vreta klosters äldsta historia. Historisk tidskrift Sextioåttonde årgången. Pp. 26-29. Stockholm.

Grønvik, O. 2003. Der Rökstein: über die religiöse Bestimmung und das weltliche Shicksal eines Helden aus frühen Wikingerzeit. Osloer Beiträge zur Germanistik 33. Frankfurt am Main: Lang.

Gustafsson, N. B. \& Vedin, E. 2007. Ett strängstall i brons från Gerete i Fardhem sn på Gotland. Fornvännen. Pp. I97-I99. Stockholm: Kungl. Vitterhets historie och antikvitetsakademien.

Gustavson, H. I99I. Rökstenen. In: Richert, A. (Ed). Svenska Kulturminnen 23. Stockholm: Riksantikvarieämbetet.

Hallberg, P. I993. Snorri Sturluson - isländsk storman och historieskrivare. In: Dahlbäck. G. (Ed): Snorre Sturlasson och de isländska källorna till Sveriges historia. Fyra föreläsningar från ett symposium i Stockholm hösten I 988 . Sällskapet Runica et Mediævalia. Opuscula I. Pp. 43-63. Stockholm: Sällskapet Runica et Mediævalia.

Harris, J. 2007. Myth and meaning in the Rök inscription. Viking and Medieval Scandinavia 2. Pp. 45-109. Turnhout: Brepols.

Heimskringla. History of the kings of Norway by Snorre Sturlasson. Translation with introduction and notes by Lee M. Hollander. Austin, Texas, I964.

Hellberg, L.I979. Forn-Kalmar. Ortnamnen och stadens förhistoria. In: Hammarström, I. (Ed.). Kalmar stads historia, I. Kalmarområdets forntid och stadens äldsta utveckling. Tiden intill I 300 -talets mitt. Kalmar: Kulturnämnden.

Henriksson, G. 1995 Riksbloten och Uppsala högar. Tor. Tidskrift för nordisk fornkunskap I. Pp. 337-393. Uppsala universitet.

Holmbäck, Å. \& Wessén, E. 1979. Svenska landskapslagar tolkade och förklarade för nutidens svenskar. Fjärde serien: Skånelagen och Gutalagen. Uppsala: AWE/ Gebers.

Jansson, S.-B. 1999. Den levande balladen. Medeltida ballad i svensk tradition. Falun: Prisma.

Jansson, S.B.F. r977. Runinskrifter i Sverige. 2d ed. Uppsala: Almqvist \& Wiksell.

- I987. Runes in Sweden. Translation: Peter Foote. Photo: Bengt A. Lundberg. Stockholm: Almqvist \& Wiksell.

Johansson, Mats I990. Tåkernbygden. En bebyggelsehistorisk analys. In: Dahlbäck. G. (Ed.). I Heliga Birgittas trakter. Nitton uppsatser om medeltida sambälle och kultur $i$ Östergötland "västanstång". Pp. 57-77. Stockholm. Humanistisk-samhällsvetenskapliga forskningsrådet.

Jónsson, F. (Ed.) I93 I. Lexikon Poeticum Antiquxe Linguxe Septrentionalis. Ordbog over det norsk-islandske skjaldesprog oprindelig forfattet af Sveinbörn Egilsson. København: Det Kongelige Nordiske Oldskriftselskab.

Kennerstedt, L. I990. Östgötaslättens romanska kyrkor. En översikt. In: Dahlbäck. G. (Ed.). I Heliga Birgittas trakter. Nitton uppsatser om medeltida sambälle och kultur i Östergötland "västanstång". Pp.I I I-I32. Stockholm. Humanistisksamhällsvetenskapliga forskningsrådet.

Kyhlberg, O. I99г. Gotland mellan arkeologi och historia. Om det tidiga Gotland. Theses and Papers in Archaeology 4. Stockholm universitet. 
Lagman, S. I989. Till försvar för runristarnas ortografi. Runrön. Runologiska bidrag utgivna av Institutionen för nordiska språk vid Uppsala universitet, I. Projektet de vikingatida runinskrifternas kronologi. En presentation och några forskningsresultat. Pp. 27-37. Uppsala.

Lönnroth, L. I977. The Riddles of the Rök-Stone: a structural approach. Arkiv för nordisk filologi 92. Pp.I-57. Lund: C.W.K. Gleerup.

Meissner, R, I92 I. Die Kenningar der Skalden:ein Beitrag zur skaldischen Poetik. Rheinische Beiträge und Hülfsbücher zur germanischen Philologie und Volkskunde. Bonn \& Leipzig.

Nationalencyklopedien. Ett uppslagverk på vetenskaplig grund utarbetat på initiativ av statens kulturråd. Elfte Bandet I993. Höganäs: Bra Böcker.

Nordberg, A. 2006. Jul, disting och förkyrklig tideräkning: kalendrar och kalendariska riter i det förkristna Norden. Acta Academiae Regiae Gustavi Adolphi XCI. Uppsala: Kungl. Gustav Adolfs Akademien.

Norr, S. I998. To Rede and to Rown. Expressions of early Scandinavian Kingship in Written Sources. Occasional Papers in Archoeology I7. Uppsala universitet.

Degnbol, H. \& Jacobsen, B.C. \& Rode, E. \& Sanders, C. \& Helgadóttir.p. (Eds) I995. Ordbog over det norrøne prosasprog. Vol. I. København: Den arnamagnæanske kommission.

Palm, R. I990. Runinskrifterna i Östergötland "västanstång”. Ålderskriterier och kronologi. In: Dahlbäck. G. (Ed). Heliga Birgittas trakter. Nitton uppsatser om medeltida samhälle och kultur $i$ Östergötland "västanstång”. Pp.79-97. Stockholm. Humanistisk-samhällsvetenskapliga forskningsrådet.

- 2004. Vikingarnas språk 750-I I00. Falun: Norsteds.

The Poetic Edda. Translated by L.M. Hollander with an Introduction and Explanatory Notes. Second ed. University of Texas, Austin I962.

The Poetic Edda. Vol. 2. Mythological Poems/edited with translation, introduction and commentaries by Ursula Dronke I997. Oxford: Clarendon.

Price, N. 2002. The Viking Way. Religion and War in Late Iron Age Scandinavia. AUN. Vol. 3 I. Uppsala university.

Ralph, B. 2007. Rökstenen och språkhistorien. In: Elmevik, L. (Ed). Nya perspektiv inom nordisk språkhistoria. Föredrag hållna vid ett symposium $i$ Uppsala 20-22 januari 2006. Acta Academiae Regiae Gustavi Adolphi XCVII. Pp. I2 I-I 43. Uppsala: Kungl. Gustav Adolfs Akademien.

Salberger, E. I980. Oklunda-hällens runristningar. In: Salberger, E. (Ed). Östgötska runstudier. Scripta runica I. Pp. 3-23. Göteborg.

Snorres Edda. Övers. och inledning av Björn Collinder I958. Oskarshamn: Forum.

Solli, B. 2004. Det norrøne verdensbildet og ethos. Om kompleksitet, kjønn og kontradiksjoner. In: Andrén, A. \& Jennbert, K. \& Raudvere. C. (Eds). Ordning mot kaos - studier av nordisk förkristen kosmologi. Vägar till Midgård, 4. Pp. 253-287. Lund: Nordic Academic Press.

Strid, J.-P. 2005 . Ett forntida kultcentrum utanför Linköping. In: Kaliff. A. \& Tagesson, G. (Eds). Liunga. Kaupinga. Kulturhistoria och arkeologi i Linköpingsbygden. Riksantikvarieämbetet. Arkeologiska undersökningar. Skrifter, 60. Pp. I47I66. Linköping: Riksantikvarieämbetet.

Sundqvist, O. I998. Kultledare och kultfunktionärer i det forntida Skandinavien. In: Westerlund. D. (Ed.) Religioner i norr. Svensk religionshistorisk årsskrift 7. Göteborg: Svenska samfundet för religionshistorisk forskning.

- 2002a. Freyr's offspring. Rulers and religion in ancient Svea society. Acta Universitatis Upsaliensis. Historia Religionum 2 I. Uppsala university. 
- Sundqvist 2002b. Håkon den gode och den ritualiserade makten. In: Stausberg, M. \& Sundqvist; O. \& Svalastog, A.L. (Ed.) Riter och ritteorier. Religionshistoriska diskussioner. Teoretiska ansatser. Religionshistoriska rapporter från Uppsala I8. Uppsala universitet.

- 2007. Kultledare i fornskandinavisk religion. Occasional Papers in Archaeology 4I. Uppsala universitet.

Sävborg, D. I997 Sorg och elegi i Eddans hjältediktning. Stockholm Studies in History of Literature 36. Stockholms universitet.

Söderberg, S. 1905. Om djurornamentiken under folkvandringstiden. Antiqvarisk tidskrift för Sverige XI:3. Stockholm: Kungl. Vitterhets Historie och Antikvitetsakademien.

Tegnér, G. I980. Ljudredskap. Lyra. Musik. Vendeltid. Pp. 323, 326. Stockholm: Statens Historiska Museum.

Wahlberg, M. (Ed). 2003. Svenskt ortnamnslexikon (SOL), Utarbetat inom Språkoch folkminnesinstitutet och Institutionen för nordiska språk vid Uppsala universitet. Uppsala: Språk-och folkminnesinstitutet.

Vikstrand, P. 200I. Gudarnas platser. Förkristna sakrala ortnamn i Mälarlandskapen. In: Andersson, Th. (Ed.) Studier till en svensk ortnamnsatlas I7. Acta Academiæ Regice Gustavi Adolphi LXXVII. Uppsala: Kungl. Gustav Adolfs Akademien.

Wessén, E. 1958. Runstenen vid Röks kyrka. KVHAA Handlingar. Filologiskfilosofiska serien 5. Stockholm: Kungl. Vitterhets Historie och Antikvitets Akademien.

Widmark, G. I993. Varför ristade Varin runor? Tankar kring Rökstenens inskrift. Saga och Sed. Kungl. Gustav Adolfs akademiens arrsbok: annales Academiae Regiae Gustavi Adolphi I992. Pp. 25-44. Uppsala: Kungl. Gustav Adolfs akademien.

- I997. Tolkningen som social konstruktion. Rökstenens inskrift. In: Nyström, S. (Ed.). Runor och ABC. Elva föreläsningar från ett symposium i Stockholm våren 1995. Pp. I65-I75. Sällskapet Runica et Medoevalia. Opuscula 4. Stockholm: Sällskapet Runica et Mediævalia.

Winkler, A.-C. 2008. Silver för nattvard eller blot? - ett depåfynd från tiden mellan asatro och kristendom i Gamla Uppsala. Uppsala Universitet: Seminar Paper.

Östergötlands runinskrifter granskade och tolkade av Erik Brate. Andra häftet I 9 I 6. Stockholm: Stockholm:Almqvist \& Wiksell international. 



\section{FORGING HISTORY}

\section{Spade-shaped currency bars, history and identity in central Norrland}

Marta Lindeberg In central Norrland a large number of spade-shaped currency bars have been recovered. Currency bars have been produced since the introduction of iron technology in the late pre-Roman Iron Age, which roughly coincides with the introduction of agriculture. It is suggested that the shape of the bars is referential to the socketed axe, due to the importance of the latter during this period of change. The currency bars were therefore associated with a mythical history and local identity. The youngest ${ }^{14} \mathrm{C}$-date shows that the bars became part of narratives that remained relevant throughout much of the Iron Age, up until the Viking Age.

Key words: central Norrland, spade-shaped currency bar, socketed axe, mythical history, identity

Currency bars (Sw. ämnesjärn) were produced in great amounts throughout Europe during the Iron Age, in different shapes that were distinctly regional (e.g. Martens I977, I979; Hingley I990, 2005; Lyngstrøm 2008). The purpose of this article is to discuss the spadeshaped currency bars of central Norrland. It has become evident that these bars cannot be interpreted solely in relation to iron technology and trade as has previously been done. In this article it will be argued that they were objects embedded with ideas connected to mythical history, origins and local identity, ideas that also came to influence the choice of place in which to deposit them.

\section{SPADE-SHAPED CURRENCY BARS}

The term "currency bar" was introduced in Britain in the early 20 th century when these bars were thought to form a kind of Iron Age cur- 
Fig. I. Known finds of spade-shaped currency bars in Scandinavia. Both hoards and single finds are included.

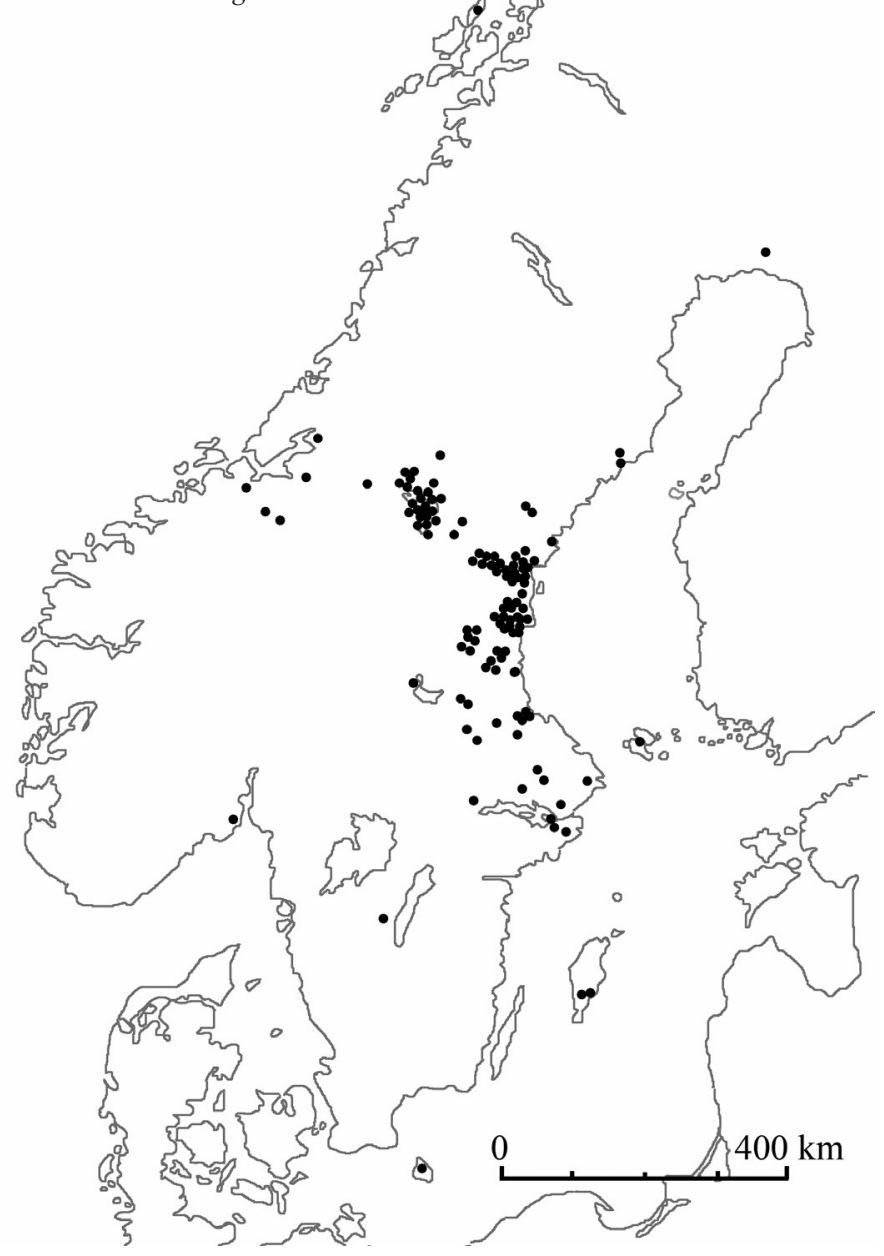

rency (Smith 1905). This interpretation is no longer tenable, which makes the term unfortunate, but it still remains in use.

Currency bars have been defined as iron which has been hammered out into a particular shape but which cannot be interpreted as a utilitarian object (Hallinder \& Haglund I 978:30). Currency bars are semiworked iron from which an object can be formed and as such they represent a technological intermediary between the bloom produced in the smelting furnace and a completed object. The iron produced in a smelting furnace needs to be further refined to become forgeable. By re-smelting and hammering the iron, the amount of slag is reduced and 
the iron is then step by step formed into a standardised shape, that is, a currency bar. The bar is then forged into an iron object.

However, there is nothing to indicate that the spade-shaped currency bars served as raw material for the manufacture of iron objects to any great extent. They are time-consuming to produce and their shape is clearly unsuitable for forging most objects, apart from cauldrons and other objects that require sheet iron (Tholander I97 I; Lindeberg 2009:95ff). Furthermore, spade-shaped bars are notably absent in the archaeological record from sites where iron-working was carried out. Instead they are found in hoards (Lindeberg 2009:63-73). This tradition has without doubt shaped the archaeological record and is the reason that so many complete currency bars have been preserved. Currency bars by definition largely disappear from the archaeological record when they are forged into objects and are commonly recovered as fragments.

Spade-shaped currency bars are primarily a Norrlandic phenomenon, and most have been found in a well-defined core area consisting of Jämtland, Medelpad, Hälsingland and Gästrikland. Hoards of spade-shaped currency bars have a clear connection to the farming districts around Lake Storsjön, along the river valleys and the coast (fig. I). Closer study of the places where spade-shaped bars were buried reveals great similarities between them. This demonstrates that the places were not chosen at random; there were definite ideas about which types of locations were suitable. Generally the hoards are found on the peripheries of the settlement districts, on the outskirts of what seem to be the outermost Early Iron Age farms (Lindeberg 2009: I 3 Iff) (fig. 2). The hoards also show a clear association with natural borders, and specifically to the places where the borders could be crossed (ibid.:I80). A close connection between settlement boundaries and hoards of currency bars is also evident in Britain (e.g. Hingley 2005).

Spade-shaped bars have been notoriously hard to date since they rarely turn up in dateable contexts. Furthermore, the hoards only seldom contain other types of objects. The handful of other objects found in hoards with currency bars suggest that they mainly belong to the period AD 300-600 (Lindeberg 2009:33ff). This assumption is strengthened by the fact that settlements and graves from the Roman Iron Age and Migration period are often found in the vicinity of the hoards. However, there are two available ${ }^{\mathrm{I} 4} \mathrm{C}$-datings that complicate the discussion, one from Torsåker in Gästrikland from 60 BC-AD I 50 cal. 


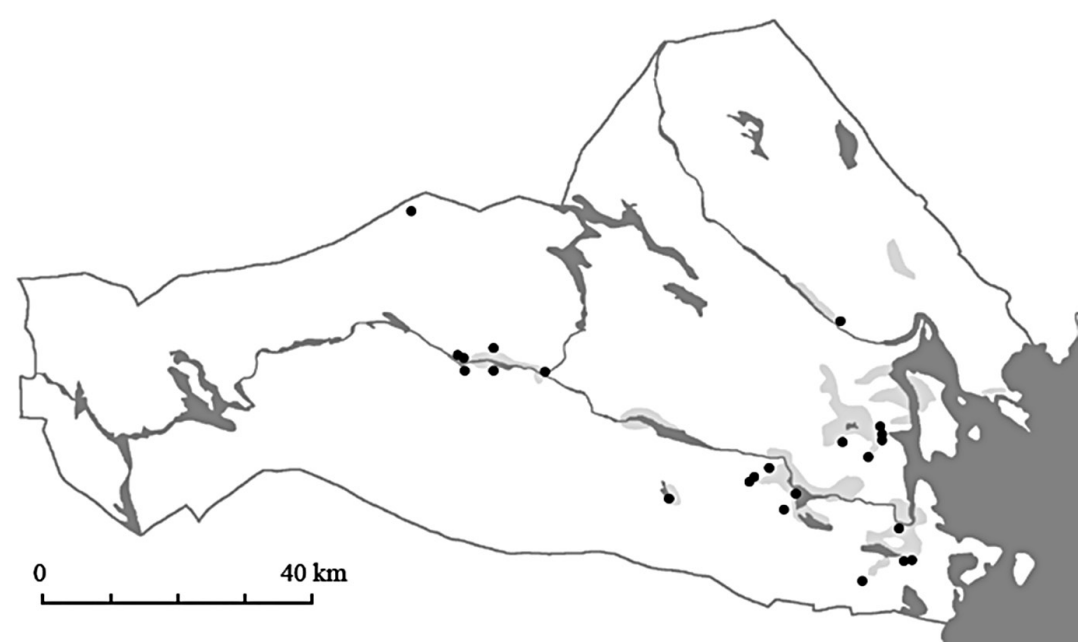

Fig. 2. The spatial relationship between hoards of spade-shaped currency bars (black dots) and Iron Age settlement districts (grey areas) in Medelpad, Sweden.

(Englund et al. 200I) and the other from Hackås in Jämtland from AD 774-94 I cal. (Possnert \& Wetterholm I 995:29). These datings indicate a remarkably long period of use. It is noteworthy that the morphology of the bars is constant over time; there is no way of distinguishing early bars from late bars simply by looking at them. This indicates that the shape was significant, as it was retained for hundreds of years.

In this part of Sweden a large-scale iron production was initiated in the interior around the time of the birth of Christ (Magnusson I986; Eriksson et al. 2008) and the early ${ }^{14} \mathrm{C}$-date from Torsåker suggests that spade-shaped currency bars were being manufactured already at the start of this production. The shape of the bars was then maintained for many centuries, perhaps until the Ioth century, that is, almost until the end of the Iron Age.

\section{A GIFT OF FERTILITY}

The spade-shaped currency bars have previously been interpreted as trade iron and the hoards have therefore been seen as temporary stores or hiding places where bars were deposited for various reasons in transit from producer to consumer (Enqvist I943:72; Thålin I967:3 I 5; Selinge 1977:377; Hallinder 1978:34). This is, however, contradicted by the sheer number of hoards that have been left in the ground and by the regularity of the find contexts, which strongly indicate that the in- 
tention was to bury the bars permanently. There are also circumstances that suggest that the burial of currency bars did not take place in secrecy and that the places where hoards had been buried were known. There are examples of reuse of these places, most obviously in Torsåker where two large blooms had been deposited about four metres from the place where the currency bars had been buried. The result from the ${ }^{\mathrm{r}} \mathrm{C}$-analysis of one of the blooms was $\mathrm{AD} 530-650 \mathrm{cal}$. This indicates that the blooms were buried about 500 years later than the currency bars (Englund et al. 200I). There are no other Iron Age remains in the vicinity, and the direct geographical relationship as well as the close connection between the deposited objects strongly suggests a relationship between the two hoards.

There are reasons to believe that the burial of currency bars should be seen in connection with ritualized activities to promote fertility. Iron production in many parts of Africa and Asia has been viewed metaphorically in terms of reproduction, where the process in the smelting furnace is a pregnancy resulting in the birth of a bloom (e.g. Herbert 1993; Barndon 200I; Haaland, Haaland \& Rijal 2002; Källén 2004:I93f). Smelting furnaces were often decorated with breasts and other female symbols and were regarded as the smelter's wife (Herbert I 993:32ff). The production of iron was thus intimately associated with fertility and procreation. Terje Gansum has interpreted stanza 40 of Voluspá as an indication that a similar symbolism relating the production of iron to birth and death likely prevailed in Iron Age Scandinavia (Gansum 2004). This is also supported by the fact that the Norwegian word for tuyere (Sw. blästermunstycke) is avlstein, or breeding stone (Haaland 2004: I6, note 6).

The placement of hoards of currency bars at what appear to be the outskirts of the outermost farms of the settlement districts is consistent and conveys the impression that the wish was to bury the hoards between the forest and the farm. At present there is very little detailed knowledge of how the landscape around the farm was organised on a micro level. Routinely graves and remains of settlements are found only in one direction from the hoards. The scarcity of these kinds of remains in the other directions suggests that these areas mainly consisted of forest, used at different levels of intensity.

The placement of the hoards on the outskirts of the farms suggests that the offerings were intended to promote fertility in the fields around the farm as well as in the forest. The forest offered a wealth of essential 
resources, including the important iron ore. Over time iron ore forms anew, which means that ore can be collected from the same bog roughly once in every generation. Since there was no conception of the chemical background of how iron ore is formed, people might have equated the process of gathering ore from bogs and lakes with the way in which crops were harvested in the fields. Securing the regeneration of the forest and the continuous formation of the ore was consequently probably steeped in ritual, and this is a possible reason why the currency bars were deposited next to the forest. It is thus consistent that the placement of currency bar hoards at the edges of waterways and bogs - the places where the ore was collected - is more common inland, where the iron production took place, whereas hoards from the coastal areas are located more generally at the edges of the settlement districts.

\section{THE SHAPE OF THE BARS}

Since currency bars have been interpreted as trade iron, the standardised shape of the bars has been seen as a way to demonstrate to a buyer that the iron could be forged, in other words that the iron was of good quality (Magnusson I986:274). Modern smiths are of the opinion that the shape as a form of quality control is well supported, but that the bars are too overworked for the shape merely to be a way to showcase the quality of the iron, as that could be achieved by simply bending the iron. Especially the sockets on the currency bars have been difficult to explain from a functional point of view (Lindeberg 2009:96f).

Historically and in modern times, half-processed trade iron has been turned into billets and flat bars, shapes that work well when forging the iron into any kind of object. The shapes of prehistoric bar iron, on the other hand, were not chosen solely from a technological point of view. Instead the shapes referred to utilitarian objects such as axes, scythes, swords and ploughs - objects which had an important function, as well as symbolism attached to them, at the time.

The object that most resembles the spade-shaped currency bar is the socketed axe, as noted already by Jan Petersen (I9I 8:I 8I) and Gustaf Hallström (1934:74, note 3). There are even instances where spadeshaped bars and socketed axes have been confused in museum inventories. The bar shares all of its constituent elements with the socketed axe, but the shape has been manipulated, a mode of procedure discernible in many types of historic and prehistoric currency bars (e.g. Martens I98I:42; Hingley I990:94; Svane I99I; Dupre I995:88ff). 
That the spade-shaped bars were given a form taken from the socketed axe would also provide an explanation for the socket of the currency bars. It is also worth mentioning that in the few instances where spadeshaped bars have been recovered with other types of objects, these are remarkably often objects with sockets (fig. 3 ).

Petersen (I9I 8:I 8I) assumed that the currency bars had evolved from the socketed axe, whereas Gustaf Hallström (I934:74, note 3) considered it to be the other way around. However, the relationship between the spade-shaped bar and the socketed axe should be understood in a more metaphorical way where the currency bar, by being given a shape referential to the socketed axe, also came to share some of the meanings that the axe held.

The spade-shaped bar is therefore referential to a socially significant object - the socketed axe - and this is doubtlessly also part of the reason why it was meaningful to bury such bars in the ground rather than to use them in the manufacture. I will return to the relationship between the two objects below.

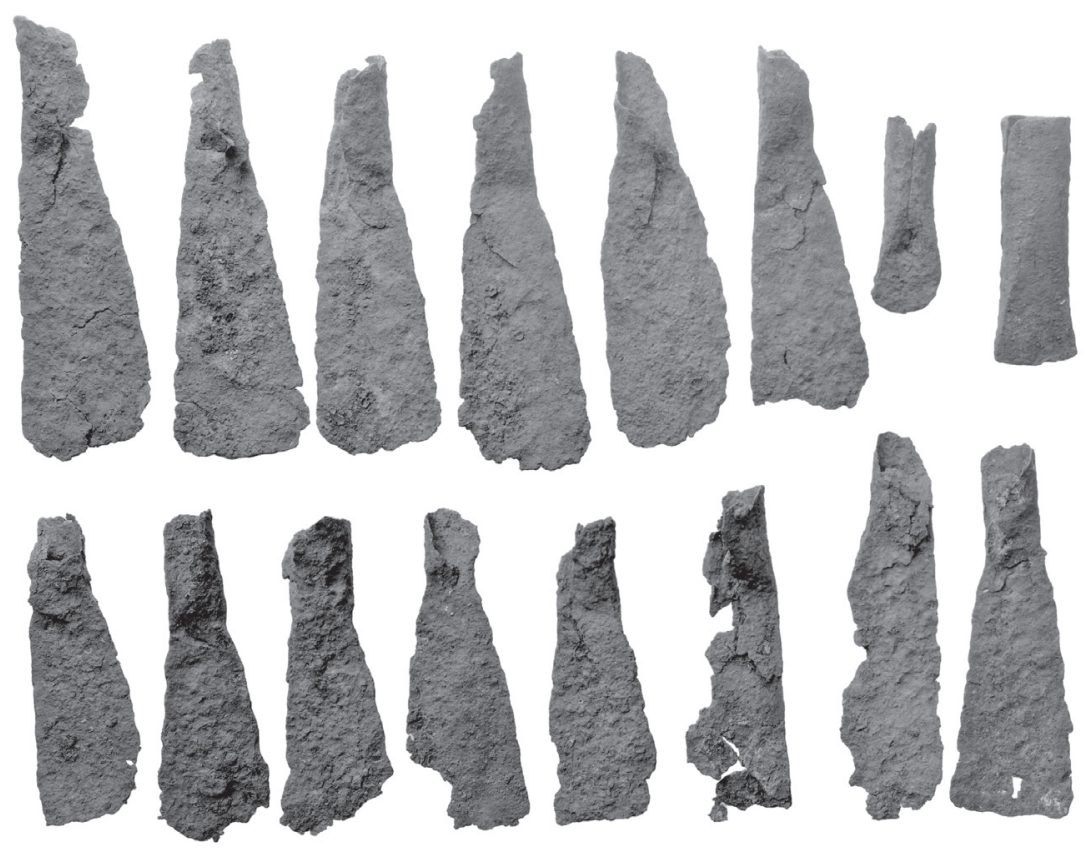

Fig. 3. Hoard from Gåcksäter in Hög parish, Hälsingland, containing spade-shaped currency bars, a socketed axe and a socketed tool (Hvarfner 1952:74). 


\section{STANDARDISATION}

The currency bars are surprisingly standardised and it is important to consider that it may have been unimaginable for smiths to be innovative when manufacturing currency bars. The bars looked the same for centuries, which indicates that the shape itself was important and that changing it was either undesirable or perhaps even impossible. Many theories about currency bars are based on the degree of standardisation they show. Standardisation turns our modern, Western thoughts to mass production and (proto-) industry (Budd \& Taylor I 995:I37ff).

Standardisation as a phenomenon is not uncommon in traditional societies, but is instead related to concepts of tradition and the handing down of knowledge. It can be seen in parallel with oral traditions. Praise and recognition are given to the one who can best tell a wellknown story, not to the creator of a new one (Ong 2003; see also Barley I 994:I I 5). Likewise pottery is extremely standardised in parts of Africa and it is not desirable to change the shape or decoration of a pot. The craft is often passed from mother to daughter according to a strict cultural tradition; and change, or rather deviation from the norm, leads to the pot being thought of as wrong or even unusable (Barley I994:76ff, I I $5 \mathrm{ff})$. Thus youth is subordinate to age and experience, and innovation subordinate to tradition. The pot functions as a model of society and as such it is a concrete manifestation of the transmission of cultural values and knowledge from one generation to the next. Since the technology of potting embodies knowledge about the world, improvisation or innovation is not appropriate and pottery is consequently surprisingly resistant to change (ibid.).

Standardisation is also common in other technological processes. Ethnographic sources from the end of the I9th century reveal that the production of copper ingots in parts of Central Africa was extremely standardised. The technology of casting bronze was handed down from father to son, and it was done in accordance with instructions that originally came from the ancestors. These were followed with the greatest accuracy, and the European officials were struck by the uniformity of the finished products (Herbert I984:190). Materials and the forms given to them thus had to fit the template accepted by that particular society.

Regarding objects that in any sense made a social statement, it is clear that neither material nor form was a random or personal matter, and this has to be taken into consideration when looking at the spade- 
shaped currency bars. There was a tradition to be considered, a definite idea about how a currency bar from central Norrland should look and how it should be used. This tradition was respected and reproduced from generation to generation. The standardisation of the spade-shaped bars should therefore not be confused with mass production or be seen as a sign of centralised or proto-industrial production. It should rather be understood as a way of dealing with tradition and history.

\section{LATER CURRENCY BARS AND ANALOGIES}

It is obvious that the intermediary form that currency bars represented, over wide areas and long periods of time, had significance beyond what could be directly connected to metalworking, and that the bars were socially and symbolically linked to other aspects of society.

Large quantities of iron were previously produced in sub-Saharan Africa. As in prehistoric Europe, there was a multitude of types of currency bars, most of which had a restricted distribution outside their area of production (Guyer I986:587; Dupre I995:83). The iron production dwindled as the 2oth century wore on, as imported iron replaced the local production. This also meant that the local production of currency bars gradually ceased (Herbert I993:I I)

Anthropological studies from large parts of Central Africa have shown that currency bars in these areas were historically often used in social rather than in economic transactions. Because iron production was intimately connected to ideas about procreation and fertility, currency bars were mostly exchanged in transactions related to marriages, mainly as bridewealth (Herbert I993:I I2; Bisson 2000:I33). As a consequence, in some communities more people were involved in the production of iron than in agriculture and hunting (Herbert I 993:I I 2). In some areas the same word was used for currency bars as for wives (Guyer 1986:578; for a more extensive discussion on this topic see Haaland et al. 2000, where hoes are related to the fertility of the field and the fertility of women).

Just as in prehistoric Europe, the shape of the bars was as a rule referential to utility objects, for instance arrow- or spearheads, axes, hoes or knives. However, even very vague shapes were explained as having been fashioned in the shape of a specific tool. The iron-producing subSaharan Africa is a vast area with great variations, but generally each type of currency bar only circulated in a defined geographical region. Both iron-producing groups and groups that did not make their own 
iron manufactured their own types of currency bars and these were only used within the group (Dupre I 995:86). Currency bars were only rarely part of long-distance trade and did not leak out of the regional systems in any significant numbers since they were not culturally acceptable outside the local area (Dupre 1995:83; Webb r999:37f). In fact, it was unusual for most people to even recognize currency bars from other areas (Guyer 1986:593). There was a high level of standardisation of the currency bars from each area, both in terms of iron and shape (Dupre I 995:78). The shapes and qualities of different types of currency bars could be similar, as well as the names of the different types, but they must not be interpreted as "dialects". The names differed because the objects differed (Guyer I986:587).

The currency bars could theoretically be worked into objects, but most remained unchanged within the exchange sphere. To work these types of bars into finished objects was considered either impossible or so highly undesirable as never to happen. When the bars were taken out of circulation around the I930s they were simply thrown away in many areas, suggesting that reforging was not an option (Guyer 1986:589). These anthropological examples can give us some perspectives on the interpretation of the archaeological material from central Norrland.

\section{A CHANGING WORLD}

The dating of the currency bars from Torsaker parish to the period around the birth of Christ suggests that the shape of the bars came into existence at the same time as a local iron production was introduced in Norrland. The dating is surprisingly early and presently this hoard is the only one that can be attributed to this early stage. The find nevertheless indicates that the shape and its significance were then reproduced for an incredibly long time, referring as they did to the introduction of iron itself. Although the chronology is not altogether clear, the introduction of iron production in Norrland coincides roughly in time with the introduction of agriculture and the establishment of permanent settlements prior to the birth of Christ - events that would have deeply changed the lives of the Iron Age people. These profound changes would also have impacted on how people perceived themselves, their mythical history and their place in the world.

Chris Gosden and Gary Lock (1998) make a distinction between two co-existing ways of dealing with the past: genealogical history and mythical history. In genealogical history the past is created through 
links to ancestors, and although forefathers and -mothers occasionally can be named surprisingly far back, the genealogical history rarely goes back further than 500 years. Beyond the genealogical history there is a mythical history that relates to the beginnings of the world, the structure of human society, mythical origins, identity and people's place in the world. I suggest that the profound changes in the period around the beginning of the first millennium required the creation of a new mythical history, and that the spade-shaped currency bars came to be associated with these mythical beginnings.

The pre-Roman Iron Age is still rather badly known in central Norrland and therefore it is uncertain exactly how the transition from a mobile society to a sedentary agricultural society took place. The transition was not synchronic and occurred at different times within the region, and there are big differences between the north and the south and between the coast and the interior. The discussion that follows mainly concerns the coastal areas, the river valleys and the district around Lake Storsjön, areas where agriculture was introduced during the course of the Iron Age and where the majority of the spade-shaped currency bars have been recovered.

There is a general lack of archaeological finds from the pre-Roman Iron Age and the first part of the Roman Iron Age in central Norrland. In early research this was seen as a sign of depopulation caused by a deterioration of the climate (e.g. Hallström I929). Today a few pre-Roman settlement finds have been identified in Tuna and Attmar in Medelpad and in Hög in Hälsingland, that is, in central districts during later parts of the Early Iron Age. Hearths, a longhouse and burnt grains have been recovered which point to the existence of a sedentary agricultural society in these parts of central Norrland before the birth of Christ (Broadbent I985; Lindström \& Olsson I986; Liedgren I988:87ff; Baudou I997). The pre-Roman Iron Age is still unidentified in Gästrikland where the earliest known Iron Age settlement remains date from the Roman Iron Age (Eriksson et al. 2008:27f). However, iron was produced in the area from the time around the birth of Christ and, as mentioned earlier, the spade-shaped currency bars from Torsåker were dated to the same period (Englund et al. 200I; Englund 2002:306).

Pollen analyses from central Norrland offer a fragmentary picture of the process. The earliest signs of localized permanent agriculture are found along the coast, in the central parts of Hälsingland from about $400 \mathrm{BC}$ and in Medelpad from around AD I (Engelmark I997:50). In 
the interior the pollen analyses indicate a long period of forest grazing, starting from the time around the birth of Christ in Medelpad (Engelmark 1978). There are some indications of cereal cultivation in the Storsjö area in Jämtland during the early Iron Age, but it is not until the Vendel period that a marked agricultural expansion is visible in the pollen diagrams (Påhlsson I989; Wallin \& Oskarsson 2002). Animal husbandry and forest grazing were most likely the foremost mode of subsistence in large parts of the interior up until the Late Iron Age or Early Middle Ages (Wallin \& Oskarsson 2002; von Stedingk \& Baudou 2006; Magnusson \& Segerström 2009). In Jämtland, however, as in Gästrikland, there are a great number of prehistoric iron production sites and the ${ }^{\mathrm{I}} \mathrm{C}$-datings show that this production was introduced during the later parts of the pre-Roman Iron Age (Magnusson I986: fig. 96).

The haziness of the period before and after the birth of Christ differs strikingly from the subsequent period. By about $\mathrm{AD} 200$ the transition was completed in the coastal areas, and there was a strong emphasis on cultivation and a settled lifestyle as manifested in the landscape through numerous mounds and houses with stone foundations. The course of events that led up to this is still not altogether established, but it was sometime during the later parts of the pre-Roman Iron Age - when forests were cleared to give way to plots and fields in the coastal areas and when a local iron production was introduced in the interior - that the socketed axe became symbolically associated with this new way of life. This coincides with the emergence of the spade-shaped currency bars. Ideas connected to history and origins were invested in the spadeshaped bars and were preserved through mythological narratives.

\section{THE SOCKETED AXE}

The socketed axe was of paramount importance in the new way of life that came into existence around the time of the birth of Christ in central Norrland, and I suggest that this is why that shape was chosen for the currency bars. The currency bars, through the axe, came to be associated with what was considered the origins of the society: iron working and the clearing of the forest to create agricultural land.

The socketed axe originated in Bronze Age axes and generally belongs to the early Iron Age (Welinder et al. 1998:335). The chronology of these axes is not conclusive, mainly because the majority of axes are stray finds (Hvarfner 1952:7) but also because dating based on ty- 
pology is unreliable for socketed axes (Serning I966:1 5). On the European mainland the socketed axes were replaced by axes with shaftholes before the birth of Christ, and from then on the socketed axe was a strictly Scandinavian phenomenon. Whereas it was replaced in southern Scandinavia during earlier parts of the first millennium, it was kept for a much longer time in Norrland, where it is occasionally found even in medieval contexts (Hvarfner I952:83ff, I I $3 \mathrm{ff}$ ). In Norrland the socketed axe was predominant up until the Vendel period, with the exception of a few axes with shaft-holes recovered in Migration period contexts (Hvarfner I952:I I3 ff, I 22ff; Liedgren I992). It is thus established that the socketed axe was used significantly longer in the areas where spade-shaped currency bars are found, and it disappears from the archaeological record at what seems to be roughly the same time as the currency bars. There is thus a strong spatial and temporal association between socketed axes and spade-shaped currency bars.

The spade-shaped bars have not spread into Norway to any great extent, but most of the Norwegian finds have been recovered in the neighbouring counties of Trøndelag and Møre (Martens I98 I:4If) (fig. I).
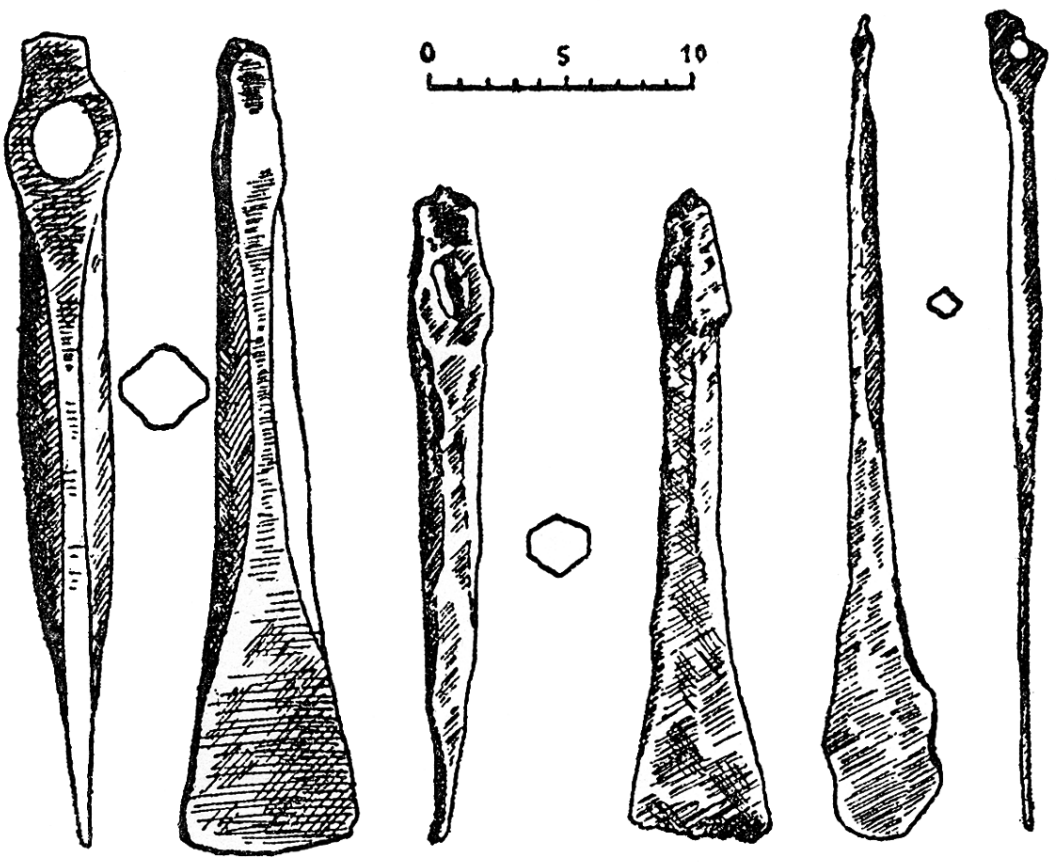

Fig. 4. The relationship between Norwegian axes and currency bars of type R438 (Nihlén I939: I08). 
As in Norrland, the socketed axe is prevalent in this area throughout most of the Iron Age. In Norway the common type of currency bar is the axiform bar of type $\mathrm{R} 438$ which is referential to the octagonal axe (No. bleggøkse) (Martens I98I; Svane I99I) (fig. 4). This type of bar has a distinct distribution area in the eastern parts of Norway, centred around Oppland, Hedmark and Buskerud, consistent with the east Norwegian distribution of the octagonal axe (Resi I995:136). The same decided geographical compliance between spade-shaped bars and socketed axes as in Sweden can thus be recognized in Norway too, and this also applies to the $\mathrm{R} 438$ bars and the octagonal axes.

The socketed axe was an all-round axe primarily used for felling trees and other kinds of woodwork. As other types of axes became more common the function of the socketed axe became more specialized, and it was used primarily as a barking spud (Sw. barkspade) (Hvarfner I952:I09ff; Myrdal I982:88f). The socketed axe could also be shafted differently and thus be turned into a hoe. Hoes were primarily used when uncultivated land was prepared for farming (Welinder, Pedersen \& Widgren I998:349ff). Finds of socketed axes in almost every metalwork hoard from Norrland also suggest that they were used in connection with smithing. This has also been put forward by Birgit Arrhenius in her discussion on grave 39 from Hovgårdsberg, Vendel parish (Arrhenius I979:4 I I). Furthermore, this type of axe can also indirectly be connected to the production of iron since it was used to fell trees for the production of charcoal needed for fuel in the smelting furnaces.

The longevity of the socketed axe in Norrland indicates that it also acquired special significance which may have created a resistance against accepting new forms of axes. Furthermore, it is likely that the outstanding practical importance of this type of axe was the reason why the spade-shaped bars were fashioned in a shape derived from it. The considerable changes that occurred at the end of the pre-Roman Iron Age were made possible because of the socketed axe; and by giving the spade-shaped bars a shape that alluded to this axe, ideas about mythical beginnings and identity became embedded in the spade-shaped bars.

\section{HISTORY AND MYTHICAL BEGINNINGS}

Mythical narratives are often intimately entwined with the landscape, and it is not unlikely that the places where hoards of currency bars have been found were important nodes in the socially constructed landscape. The concentration of currency bars to the areas where they 
were produced, in conjunction with the places chosen to deposit them, indicates that they were related to and significant for the local history and identity. The individual places where hoards have been found are not identical but there are obvious similarities between them. This is a clear indication that the placement of the hoards in the landscape was meaningful and that the currency bars and the surrounding environment should be seen as parts forming a totality.

Hoards of spade-shaped currency bars occur over large parts of central Norrland. As mentioned earlier, central Norrland is a large area with great differences, primarily between the coastal areas and the densely forested interior. Spade-shaped bars, on the other hand, have been found both in the interior and along the coast.

In the coastal areas there are numerous burial mounds and houses, manifestations of an identity firmly based on agriculture. These types of constructions are more or less absent in the interior during the Early Iron Age. There are graves in the interior, too, but in smaller numbers and in specific settings; often they are found on narrow headlands in lakes. This lack of graves has sometimes been taken to mean there were no settlements in the interior. However, the large number of iron production sites, and other traces of activities connected to iron production, clearly demonstrates that the interior was inhabited, but by people who expressed their presence in other ways than through burial mounds and houses with stone foundations (Sandqvist 2004:22). Instead it is more than likely that the identity of the people of the interior was somehow connected to their roles as iron producers.

During the Migration period there was a marked settlement expansion, and agricultural areas similar to the ones along the coast were for the first time visible in parts of the interior areas, primarily in the Storsjö area and along the river valleys. It is probable that the majority of the hoards of currency bars can be seen in conjunction with this stage when new farms were established over larger areas than before. Although there were still differences between the coastal and inland areas, the same kinds of constructions were now found in both areas although in fewer numbers in the interior. During the course of the Iron Age, iron production sites also appeared in the coastal areas, a few in Hälsingland and in greater numbers in Gästrikland. It is at this point that the symbolic importance of the spade-shaped currency bars emerged and it became expedient to deposit them. The social meanings held by the currency bars, coupled with ideas about the origins of so- 
ciety - opening up the landscape, clearing forests for farming and iron production - were so broad as to appeal to people in different parts of central Norrland. It was possible, through the lens of the currency bar, to conciliate these different activities and ways of life to a narrative of origins and identity. The currency bars spoke to the worldviews of coastal dwellers and their inland counterparts, and could therefore bind them together, just as they bound together the forest and the farm.

\section{CONCLUSION}

The spade-shaped currency bars were socially significant objects, which, when buried in the ground, firmly fixed history to the present in the landscape at the same time as they offered assurance of a good future. Through the shape, referential to the socketed axe, the currency bars were associated with narratives about the origins of the society and local identity, and the forging of currency bars, as well as the deposition of them, probably constituted important ways to pass down this knowledge over the generations. When spade-shaped currency bars were forged, in effect history and a local identity were forged, providing a constant in a changing world. The hoards were probably deposited by people from the nearby farms and were subsequently incorporated into the social memory of the society. Although the hoards were invisible above ground, their tendency to cluster in close proximity to each other is evidence of just how active and long-lasting this tradition was, not least at a place like Kråknäset in Torsåker where 500 years separate the two depositions. The spade-shaped currency bars offer a glimpse of a worldview different from our own, one in which the intermediary form that the bars represented bestowed on them a much fuller significance than did their place in the production process.

Marta Lindeberg, Department of Archaeology and Classical Studies, Stockholm University, I06 9I Stockholm, Sweden 


\section{REFERENCES}

Arrhenius, B. 1979. Ein Goldschmiedegrab von Hovgårdsberg, Vendel, Uppland, Schweden. Frübmittelalterliche Studien. Bd I3. Pp. 393-4I 4. Münster.

Barndon, R. 200I. Masters of metallurgy - Masters of metaphors. Iron working among the Fipa and the Pangwa of SW-Tanzania. Department of Archaeology. Bergen: University of Bergen.

Barley, N. 1994. Smashing Pots. Feats of Clay from Africa. London: British Museum Press.

Baudou, E. I997. Om uppkomsten av järnålders jordbruksbygd i Mellannorrland och boplatsen vid Tuna kyrka. Arkeologi i Mittnorden. Ett symposium kring nya arkeologiska forskningsrön. Acta Antiqua Ostrobotniensia. No. 4. Pp. I I43.Vasa.

Bisson, M. S. 2000. Precolonial copper metallurgy: Socio-political context. In: Vogel, J.O. (Ed.). Ancient African metallurgy: the sociocultural context. Pp. 83-I45. Walnut Creek: AltaMira Press.

Broadbent, N. I985. New Knowledge of Early Iron Age Settlement in Northern Sweden. Cooperation between the University of Umeå and the Västernorrland County Museum. In: Honorem Evert Baudou. Archaeology and Environment. No. 4. Pp. 387-393. Umeå.

Budd, P \& Taylor, T. 1995. The faerie smith meets the bronze industry: magic versus science in the interpretation of prehistoric metal-making. World Archaeology. Vol. 27. No. I. Pp. I33-I 43.

Dupre, G.I995. The History and Adventures of a Monetary Object of the Kwélé of the Congo: Mezong, Mondjos and Mandjong. In: Guyer, J. I. (Ed.). Money Matters. Instability, Values and Social Payments in the Modern History of West African Communities. Pp. 77-97. Portsmouth: Heinemann.

Engelmark, R. 1978. The Comparative Vegetational History of Inland and Coastal Sites in Medelpad, N Sweden, during the Iron Age. Early Norrland I I. Pp. 2562. Stockholm.

Engelmark, R. 1997. Övergången bronsålder/järnålder i Mellannorrland. Arkeologi i Mittnorden. Ett Symposium kring nya arkeologiska forskningsrön. Acta Antiqua Ostrobotniensia. No 4. Pp. 45-52. Vasa.

Englund, L-E. 2002. Blästbruk. Myrjärnshanteringens förändringar i ett långtidsperspektiv. Jernkontorets bergshistoriska skriftserie nr 40. Stockholm: Jernkontoret.

Englund, L-E, Grandin, L \& Hjärthner-Holdar, E. 200I. Datering av spadformat ämnesjärn och smälta. Kråknäset, Fors 27:3, Torsåker socken, Gästrikland. Geoarkeologiskt Laboratorium. Analysrapport nr I3-200I. Stockholm: RAÄ UV GAL.

Enqvist, A. I943. Ett förhistoriskt depåfynd i Sundsvall. Årsbok för Sundsvalls gille. Pp. 65-74. Sundsvall.

Eriksson, K, Persson, M \& Ulfhielm, B. 2008. Arkeologisk forskningshistorik över Gävleborgs län 2007. Rapport 2008:05. Gävle: Länsmuseet Gävleborg.

Gansum, T. 2004. Jernets fødsel og dødens stål. Rituell bruk av bein. In: Berggren, Å, Arvidsson, S \& Hållans. (Eds.). Minne och myt. Konsten att skapa det förflutna. Vägar till Midgård 5. Pp. I2 I-I 5 5. Lund: Nordic Academic Press.

Gosden, C \& Lock, G. I998. Prehistoric histories. World Archaeology. Vol. 30. No. I. Pp. 2-I 2.

Guyer, J. I. I986. Indigenous Currencies and the History of Marriage Payments. Cahiers d'Etudes africaines. Vol. 26. No.104. Pp. 577-610. 
Haaland, R. 2004. Technology, Transformation and Symbolism: Ethnographic Perspectives on European Iron Working. Norwegian Archaeological Review. Vol. 37. No. I. Pp. I-I9.

Haaland, G, Haaland, R \& Rijal, S. 2002. The Social Life of Iron. A Cross-Cultural Study of Technological, Symbolic, and Social Aspects of Iron Making. Anthropos. Vol. 97. No. I. Pp. 35-54.

Hallinder,P. 1978 . Spade-shaped currency bars. In: Lamm, K \& Lundström,A.(Eds.). Excavations at Helgö V:I. Pp. 30-37. Stockholm: KVHAA.

Hallinder, P \& Haglund, K. I978. Iron currency bars in Sweden. In: Lamm, K \& Lundström, A. (Eds.). Excavations at Helgö V:I. P. 30 . Stockholm: KVHAA.

Hallström, G. I929. Kan lapparnas invandringstid fixeras? En arkeologisk studie. Norrlands försvar. Pp. 39-92.

Hallström, G. I934. Segersta och Hanebo socknars förhistoria. Två Hälsingesocknar. Pp. 2 I-94. Landafors.

Herbert, E. W. 1984. Red Gold of Africa. Copper in Precolonial History and Culture. Madison: University of Wisconsin Press.

Herbert, E. I993. Iron, Gender and Power. Rituals of Transformation in African Societies. Bloomington: Indiana University Press.

Hingley, R. 1990. The Iron Age ‘Currency Bars’: The Archaeological and Social Context. The Archaeological Journal. Vol. I47. Pp. 9I-I I7.

Hingley, R. 2005. Iron Age 'currency bars' in Britain: items of exchange in liminal contexts? In: Haselgrove, C \& Wigg-Wolf, D. (Eds.). Iron Age Coinage and Ritual Practices. Studien zu Fundmünzen der Antike (SFMA). Band 20. Pp. I $83-205$.

Hvarfner, H. I952. Yxor av järn. Unpubl. Diss (Lic). Nordiska museets arkiv.

Jones, A. 2007. Memory and Material Culture. Cambridge: Cambridge University Press.

Källén, A. 2004. And through flows the river. Archaeology and the pasts of Lao Pako. Studies in Global Archaeology 6. Uppsala: Uppsala University.

Liedgren, L. I 988 . Synpunkter på den sedentära bebyggelsens etablering i Norrland. Bebyggelsehistorisk tidskrift. Vol. I4, I987. Pp. 83-I04.

Liedgren, L. 1992. Hus och gård i Hälsingland. En studie av agrar bebyggelse och bebyggelseutveckling i norra Hälsingland Kr.f.-60o e.Kr. Studia Archaeologica Universitatis Umensis 2. Umeå: Umeå University.

Lindeberg, M. 2009. Järn i jorden. Spadformiga ämnesjärn i Mellannorrlands järnålder. Stockholm Studies in Archaeology 49. Stockholm: Stockholm University.

Lindström, M \& Olsson, R. 1986. Förundersökning vid Bällsta, Matfors, Tuna sn, Västernorrlands län. Rapport Länsmuseet Murberget. Härnösand: Länsmuseet Murberget.

Lyngstrøm, H. 2008. Dansk Jern. En kulturbistorisk analyse af fremstilling, fordelning og forbrug. Det kongelige nordiske oldskriftselskab. Köpenhamn: Lynge \& Søn.

Magnusson, G. I986. Lågteknisk järnhantering i Jämtlands län. Jernkontorets bergshistoriska Skriftserie 22. Stockholm: Jernkontoret.

Magnusson, G \& Segerström, U. 2009. Leva i skogsbygd. När blev människan bofast i södra Norrland? Bebyggelsehistorisk tidskrift. No 57. Pp. 7-25.

Martens, I. I977. De norske jerndepoterne fra folkevandringstid-middelalder. Bergshistoriska utskottets höstmöte I976. Jernkontorets forskning H I3. Bilaga 4. Pp. I-5. Stockholm: Jernkontoret. 
Martens, I. I979. Jerndepoterne - noen aktuelle problemstillinger. In: Løken, T.(Ed.). Jern og jernvinne som kulturhistorisk faktor i jernalder og middelalder $i$ Norge. AmS-Varia 4. Pp. 59-64. Stavanger: Arkeologisk museum.

Martens, I. I98г. Noen synspunkter på produksjon og distribusjon av jern i Norge i yngre jernalder. Universitetets Oldsaksamling Årbok I980/I98I. Pp. 97-IO2.

Myrdal, J. I982. Jordbruksredskap av järn före år ıooo. Fornvännen. Pp. 8 I-I04.

Nihlén, J. I939. Äldre järntillverkning i Sydsverige. Studier rörande den primitiva järnhanteringen $i$ Halland och Skåne. Jernkontorets bergshistoriska skriftserie 9. Stockholm: Nordisk bokh.

Ong, W. J. 2003 [1982]. Muntlig och skriftlig kultur. Teknologisering av ordet. Göteborg: Anthropos.

Petersen, J. I9I 8. Jernbarrer. Oldtiden. Bind VII. Pp. I7 I-I 86.

Possnert, G \& Wetterholm, A. I995. Radiocarbon Dating of Iron. Norwegian Archaeological Review. Vol. 28. No. I. Pp. 19-30.

Påhlsson, I. I989. Ändsjön, en nyckel till forntiden. Arkeologi i fjäll, skog och bygd. No. I. Pp. I35-I43. Östersund: Heimbygdas förlag.

Resi, H. G. I995. The Norwegian iron bar deposits: have they most to tell about production, distribution or consumption? In: Resi, H. G. (Ed.). Produksjon og samfunn. Beretning fra 2. Nordiske jernaldersymposium på Granavolden 7.-IO. mai I 992. Varia 30. Universitetets oldsaksamling. Pp. I3 I-I 46. Oslo.

Sandqvist, E. 2004. Identiteter i Hälsingland under den yngre järnåldern - när järnframställning, runstenar och gravar talar olika språk. Föredrag vid seminarium Vikingar från alla håll på Historiska museet i Stockholm tisdagen den 3 december 2002. Pp. 20-23.

Selinge, K-G. I977. Järnålderns bondekultur i Västernorrland. In: Baudou, E \& Selinge, K-G. Västernorrlands förhistoria. Härnösand: Akademilitteratur.

Serning, I. 1966. Dalarnas järnålder. KVHAA Monografier. Stockholm: Almqvist \& Wiksell International.

Smith, R. 1905. The ancient British iron currency. Proceedings of the Society of Antiquaries. Vol. 20. Pp. I79-I95.

von Stedingk, H \& Baudou, E. 2006. Capitalism in Central Norrland, Sweden, during the Iron Age. Current Swedish Archaeology. Vol. I4. Pp. I77-I98.

Svane, H. I99I. Rhombic iron axes and axiform currency bars from Norway. Materiaty Archeologiczne. Vol. XXVI. Pp. 3 I-33.

Tholander, E. I97I. En teknikers funderingar om Norrlandsjärn och Tröndelagssalt i förhistoriskt handelsutbyte. Fornvännen. Pp.I-I7.

Thålin, L. I967. Svenskt förhistoriskt järn - ett forskningsprojekt. Jernkontorets Annaler. Vol. I 5 I. Pp. 305-324.

Wallin, J-E \& Oskarsson, B. 2002. Odlingslandskapets framväxt i Storsjöbygden. En miljöhistorisk studie i järnåldersbygd, baserad på pollenanalyser och GISbaserade kartanalyser. Kulturhistorisk utredning 50 . Östersund: Jämtlands läns museum.

Webb, J. L. A, Jr. I999. On Currency and Credit in the Western Sahel, I700-I 850. In: Stiansen, E \& Guyer, J. I. (Eds.). Credit, Currencies and Culture. African Financial Institutions in Historical Perspective. Pp. 38-55. Uppsala: Nordiska Afrikainstitutet.

Welinder, S, Pedersen, E. A, Widgren, M. I998. Jordbrukets första femtusen år. 4000 $f . K r$.-I00o e.Kr. Det svenska jordbrukets historia. Stockholm: Natur och kultur. 



\section{VEITSTU HVÉ BLÓTA SKAL?}

\section{The Old Norse blót in the light of osteological remains from Frösö Church, Jämtland, Sweden}

Ola Magnell \&

Elisabeth Iregren

\begin{abstract}
The osteological remains from Frösö Church, Jämtland, have been re-analysed in order to understand the Viking Age rituals at the site and to study the blót, the Old Norse sacrifice and feast. Radiocarbon analyses of animal and human bones date the rituals to the late Viking Age. A taphonomic study shows that especially brown bear and pig were of importance in the rituals. Butchering marks reveal the processing of the carcasses as well as feasting. Further, bones and not whole carcasses seem to have been deposited on the ground. Human remains have been treated differently from the animal bones and may represent disturbed burials rather than sacrifices. Seasonal analysis indicates that the rituals took place in late autumn, early spring, and possibly around the summer solstice. The results of the osteological analyses are also discussed in relation to the written sources about the Old Norse blót.
\end{abstract}

Key words: Old Norse, Frösö, animal sacrifice, blót, taphonomy, seasonality

\section{INTRODUCTION}

Excavations in the choir of Frösö Church in 1984 revealed bones scattered around the mouldering remains of a birch tree. The abundance of bones from wild animals, the body part frequency, and the unique find context of bones and tree remains here on the island of Freyr (Frösö) showed that the find most likely represents the remains of the blót, the Old Norse sacrifice and feasting (Iregren I989).

The Old Norse word blót means sacrifice (Palm 2004:483). In this study blót refers to the public sacrifices of animals and the ceremonial feasts at sacred places, which are described in the written sources 
(Näsström 200I). The archaeological evidence of the blót and animal sacrifice is rather scanty. This can be explained by taphonomic factors and the problem of distinguishing between bones from ritual feasts and those from ordinary meals.

The bones from Frösö Church are one of the most important archaeological sources of information on Old Norse animal sacrifices, and have also been used as an example of this ritual practice (Näsström I996:80; 200I:II 2ff; Jennbert 2002:III). Animal bones in graves are another important and relatively common source material, but they represent specific mortuary rituals (Iregren I997). Another relatively common ritual practice during the Iron Age is depositions of animal bones in house structures (Paulsson-Holmberg 1997; Carlie 2004). However, these rituals are closely related to the construction or abandonment of houses, and in some cases the interpretations of the bone finds in postholes as ritual depositions can be questioned. Bones of animals and humans in bogs are further evidence of pre-Christian ritual sacrifices, but this type of deposition is part of an older tradition which diminishes during the

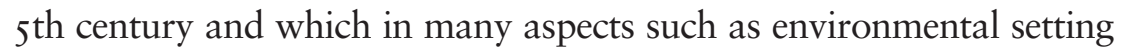
differs from the religious ceremonies and sacrifices that took place at settlements during the Late Iron Age (Fabech I99 I:97; Nilsson 2009:95ff).

There are few other finds of Old Norse cult places with animal bones in Sweden. Borg in Östergötland and Uppåkra in Scania are examples of other cult places with probable remains of sacrificed animals (Lindeblad \& Nielsen I997; Magnell, in press). These sites are also more problematic to interpret, with less clear evidence of animal sacrifices and ritual depositions than the bones from Frösö Church. Other examples of Viking Age bone finds, from Tibble in Uppland and Järrestad in Scania, are interpreted as ritual depositions, but the interpretations of these bone depositions as sacrificed animals can be questioned (Andersson I 998:252; Nilsson 2003).

The osteological remains from the site have earlier been analysed and published by Elisabeth Iregren (I989). The development of osteological methods as well as new detailed analyses has made it possible to obtain new information from the material. An additional purpose of the study has been to sort out misconceptions of the find in connection with its presentation in other publications.

The descriptions of the blót in the written sources can also be questioned since they are usually not eyewitness accounts of the rituals but instead were written down several generations after the pre-Christian 
religious practice had been abandoned. The descriptions were also written down by Christians for specific purposes and it is likely that the descriptions have been exaggerated and distorted (Clunies Ross 2002; Sundqvist 2007:II). The most cited and important written source is the account of the blót in Gamla (Old) Uppsala by Adam of Bremen. Its validity and the extent to which it actually describes Old Norse rituals have been debated (Hultgård I997; Janson I998:I7ff). There are many aspects of the blót that at present are uncertain and questionable. Which animals were sacrificed? Were humans sacrificed? During what time of year did the blót take place? These are examples of questions that will be discussed in this study.

This paper deals with three main issues. Firstly, radiocarbon dating has been done in order to establish the chronology. Secondly, a detailed analysis has been performed in order to reconstruct the taphonomic history of the bones - from the selection of animals for sacrifice, to the slaughter, to the deposition of bones at the site. Thirdly, a detailed age assessment of the animal remains has been done in order to try to estimate during which part of the year the rituals took place.

The aim of the study has been to better understand the rituals that took place at Frösö in the Viking Age, but also to compare the archaeological and osteological evidence with the written sources and generally accepted view of the Old Norse ritual practice at the blót. In short, we will try to answer the question posed by Odin himself in Havamál: veitstu hvé blóta skal? "Do you know how to sacrifice?"

\section{LANDSCAPE AND SITE DESCRIPTION}

During the Viking Age Frösö was most likely the social, political and religious centre in the Lake Storsjö region in the province of Jämtland, Sweden. That the site where Frösö Church now stands was important in the Late Iron Age society is indicated by burial mounds in the churchyard and by the name of the village near the church - Hov (Hemmendorff 20IO). The exact meaning of the Old Norse word hov (hof) is unclear, but it usually refers to a building with a sacred function (Vikstrand 200I:253ff; Sundqvist 2007: I 59; Jakobsson I997).

The area around Frösö can be described as a sacred landscape with several place names linked to the Old Norse religion (Fig. I). The gods Freyr, Odin, Njord and Ull can be associated to the places Frösö, Odensala, Norderön and Ullvi, while Vi and Hov in five different places refer to cult sites (Brink I990; Vikstrand I993). 

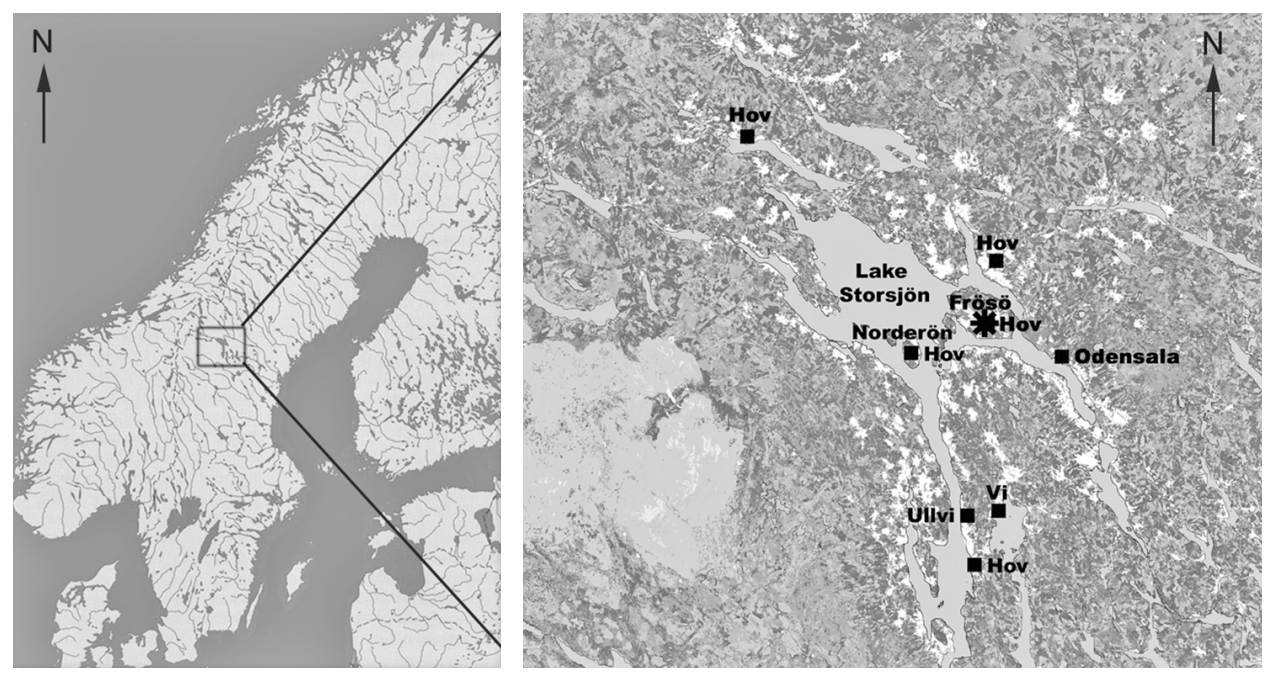

Fig. I. Scandinavia and the Lake Storsjö area (left), Frösö Church ("*) and Old Norse place names in the Lake Storsjö area (right).

The setting of the site in the landscape, with a wonderful view on one of the highest summits of the island Frösö I $30 \mathrm{~m}$ above Lake Storsjön, was most likely chosen carefully. The site may have had a cosmological meaning, even though strategic and social factors could explain why this place became the centre of the cult. When standing on the site gazing westward one gets the impression that one is in the middle of the cultural landscape by the lake; further away lie the forests, and in the distance are the mountains that surround the landscape. It is difficult not to avoid parallels with the Old Norse spatial cosmology where Midgaird (Middle World), the settled and ordered world of the humans, was surrounded by Utgaird, the home of the giants and chaos. Frösö and the area by Lake Storsjön may have represented Midgård, while the mountains in the distance represented Utgard. That people during the Viking Age actually had this simple dualistic worldview of the spatial mythology has been criticized (Brink 2004:292ff). However, that the concept of Midgård was important is not doubted (Clunies Ross I 996:60). It has also been suggested that other cult sites, such as Gamla Uppsala, reflected a mythical landscape (Sundqvist 2007: I I 4ff).

The argument that the site of Frösö Church really was a cult centre from a cosmological perspective is further confirmed by remains of the birch tree below the choir. The tree is interpreted to represent the world tree, Yggdrasil (Iregren I989: I 3 of; Näsström I996:79f). Accord- 
ing to the Old Norse mythology Yggdrasil was standing in the middle of the cosmos, connecting the different worlds (Andrén 2004:390f; Näsström 2006:27ff).

Due to renovation an excavation by Jämtlands läns museum took place in Frösö Church in I984. Below the floor in the choir was a thin layer of pulverized wood, which most likely represents the remains of an earlier floor in the church, and beneath the latter was found a black cultural layer with bones, fire-cracked stones and charcoal covering an area of $3 \times 3 \mathrm{~m}$. The remains of a stump and roots of a birch tree were found in the middle of the choir. Bones were found on top of the roots and not beneath or on the tree stump. No other finds apart from bones, an iron pin from a buckle, and an iron crook were recovered. The cultural layer was missing in the western part due to the construction of graves during the I 8 th century and a sepulchral chamber. The eastern and southern walls of the choir also cut the cultural layer. It is not known whether the layer with bones continues outside the church. Consequently the original extension of the layer with bones is most uncertain (Hildebrandt I989:I62f).

\section{MATERIAL}

The osteological material of $5 \mathrm{~kg}$ has earlier been analysed and published by Elisabeth Iregren (1989). A new quantification of the frequency of different animals has been done (Table I). The reason for this is a misprinting in the publication from I989, and in the earlier analysis ribs and bones of the vertebral column were not determined as to species (Iregren I989). The identification of loose teeth and assessments of age have also resulted in new estimates of the minimal number of individuals.

The new quantification of NISP (number of identified specimens) has resulted in a slightly higher frequency $(4 \%)$ of wild game in relation to domestic animals. The frequency of brown bear (Ursus arctos) has increased by $5 \%$, while sheep and goat (Ovis/Capra) have decreased by $6 \%$. Other species have about I $\%$ or less difference between the earlier and the new quantification. The new estimation of MNI has resulted in a higher number of individuals, but the relationship between the species is more or less the same.

In this study, bones of bat (Chiroptera), rodents (Rodentia), jackdaw (Corvus monedula), passerines (Passeriformes) and whitefish (Coregonus) have been excluded, since these bones either are from a younger 


\begin{tabular}{|c|c|c|c|c|c|c|c|c|c|c|c|c|c|c|}
\hline Cranium & 9 & & & & & 7 & & & 3 & 3 & & & & 1 \\
\hline Teeth (maxilla) & 7 & 1 & 3 & & & 10 & & & 3 & 7 & & & & \\
\hline Mandible & 12 & 16 & & & & & & 5 & 2 & 72 & & & & \\
\hline Teeth (mandible) & 35 & 60 & 11 & & & 9 & 1 & & 9 & 36 & 1 & 1 & & \\
\hline Teeth & 1 & & & & & & & & 4 & & & & & \\
\hline Atlas & & & & & & 1 & & & & & & & & \\
\hline Axis & 1 & & & & & 1 & & & & & & & & \\
\hline Cervical vert. & 4 & & & & & & & & & 1 & & & & \\
\hline Thoracic vert. & 12 & & & & & & & & 2 & & & & & 4 \\
\hline Ribs & 6 & & & & & 1 & & & & & & & & 7 \\
\hline Sternum & 4 & & & & & & & & & & & & & \\
\hline Lumbar vert. & 2 & & & & & & & & & & & & & \\
\hline Sacrum & & & & & & & & & & & & & & \\
\hline Caudal vert. & 2 & & & & & & & & & & & & & \\
\hline Scapula & & & & & & & & & & & & & 1 & 2 \\
\hline Humerus & 3 & & & & & 1 & & & 2 & 1 & & & & \\
\hline Radius & 5 & & & & & & & & 1 & & & & & \\
\hline Ulna & 3 & & & & 2 & & & & & 1 & & & & \\
\hline Carpals & 12 & & & & & 1 & & & & & & & & 3 \\
\hline Metacarpals & 11 & & & & & & & & & & & & & 1 \\
\hline Pelvis & & & & & & 2 & & & & & & & & 1 \\
\hline Femur & 2 & & & & & & & & 1 & & & & & \\
\hline Tibia & 4 & & & & 1 & 1 & & & 1 & & & & & 1 \\
\hline Fibula & 2 & & & & & & & & & & & & & \\
\hline Tarsals & 14 & & & & & & & & 3 & & & & & 1 \\
\hline Metatarsals & 11 & & & 4 & & & & & 1 & & & & & 2 \\
\hline Metapodia & 16 & & & & & & & & 1 & & & & & \\
\hline Sesamoideum & 22 & & & & & 1 & & & & & & & & \\
\hline Phalanx 1 & 34 & & & 2 & & & & & & & & & & 6 \\
\hline Phalanx 2 & 22 & & & & & 1 & & & & & & & & \\
\hline \multicolumn{15}{|l|}{ Phalanx 3} \\
\hline NISP & 256 & 77 & 14 & 6 & 3 & 36 & 1 & 5 & 33 & 121 & 1 & 1 & 1 & 29 \\
\hline MNI & 7 & 7 & 2 & 1 & 1 & 4 & 1 & 4 & 1 & 14 & 1 & 1 & 1 & 4 \\
\hline
\end{tabular}

Table r. Osteological remains of mammals and birds from Frösö Church (layer RL 6). Additionally two bones of pike and one of salmon have not been included in the table. NISP = Number of Identified Specimens. MNI = Minimal Number of Individuals. 
layer in the nave or most likely are later intrusions in the Viking Age cultural layer (Iregren I989:I 20). Nine bones from cattle, sheep and pigs differ significantly from the other bones by being white-grey and showing no signs of weathering in contrast to the otherwise brown-red and weathered bones. These bones are from a limited area in the northern part of the choir and are assumed to be of a younger date, probably from the time of the construction of the church. Because of this, these bones have also been excluded from the quantification.

\section{METHODS}

The development of methods for age estimation of pigs, sheep and European elk has occurred since the earlier analysis was made. This has made it worthwhile to re-access mandibles and teeth with the aim of finding further evidence of the seasonality.

The age estimation is based on development and wear of teeth of pig, cattle, sheep and elk (Brown et al. 1960; Jones 2006; Carter \& Magnell 2007; Magnell, manuscript). Additional radiographs of mandibles of recent newborn calves and lambs of known age at death have been taken and used by the authors to verify the age assessments.

It has been assumed that tooth development in Viking Age animals is generally similar to that of animals of today. However, since the modern improved pig breeds develop faster than primitive breeds of the past, tooth development in wild boar and in crossbreeds between wild and domestic pigs has been used as reference material for the Viking Age pigs (Carter \& Magnell 2007).

In order to assess the seasonality one has to combine the age estimation with an assumed breeding period. The breeding of wild animals like brown bear and elk is today restricted to short periods in January/ February and late May/early June, respectively (Ekman et al. I992:68; Sandegren \& Swenson I 997:2I). There is no reason to assume that the situation was different during the Viking Age. Sheep in Sweden today usually lamb in the spring, in April/May (Insulander 1956:88f). Since the onset of the rut and lambing in sheep is affected by decreasing daylight in the autumn, there is no reason to assume different conditions in the past (Sjödin I980:124).

It is more problematic to evaluate the animals that do not have limited breeding seasons, like pigs, cattle and goats. However, in areas with great seasonal differences in climate and food supply, like Jämtland, the breeding of livestock is often more restricted to the spring in order 
to increase the chance of offspring surviving their first winter, and this was also the case with their wild ancestors.

As an example, wild boar can and does breed in different seasons, but in Sweden about $90 \%$ of the farrows are in the spring (Lemel I999:33). In this study it has been assumed that reproduction in pigs during the Viking Age was similar to that of wild boar, with most piglets born in early spring. However, it cannot be excluded that the pigs had two farrows a year, one main breeding period in spring and occasionally one in late summer, just as wild boar has in years of good food supply and according to historical sources on pig breeding (Lauwerier I983). The results of the analysis and clustering of the piglets in two limited age groups, 2-4 months and 7-9 months respectively (see results), thus indicate seasonality in the breeding of pigs. If reproduction in pigs had not been tied to specific periods it is unlikely that the age of the slaughtered piglets would be found in restricted age groups, but instead randomly spread out over the year.

Sources on reproduction in goat from the I 9 th and early 20 th centuries reveal that the kids were born in spring (Dahlander 1916:72; Fägerborg I986:I 26). The natural reproduction in horse is a rut in late spring/early summer, resulting in the foal being born in spring (Rossdale I996:66). Since calving in spring is natural for cattle and was preferred by farmers in the past, this has been assumed in our study as well (Richter I982:258; Berg I986:I I2). Historical sources on reproduction in cattle in Sweden also show that calving in northern Sweden and Småland was concentrated to spring (Nathorst I877:I6I; Larsson 2009:I25).

Identification of sheep and goat has been based on criteria for mandible according to Boessneck et al. (1964) and dentition after Payne (1985). In a recent publication by Zeder and Pilaar (2010) several of the criteria described by Payne (I985) have been criticized. Since the analysis of the osteological material from Frösö Church was performed before the publication by Zeder and Pilaar (20I0), the identification of goat can be questioned. However, this does not have any influence on the seasonal analysis.

The presence of butchering marks on bones was noticed in the earlier analysis, but no systematic and detailed study of bone modifications was performed. Since the taphonomic history of the bones is of interest in this study, bones have been examined with a stereo-microscope in order to identify bone modifications. Weathering has been recorded according 


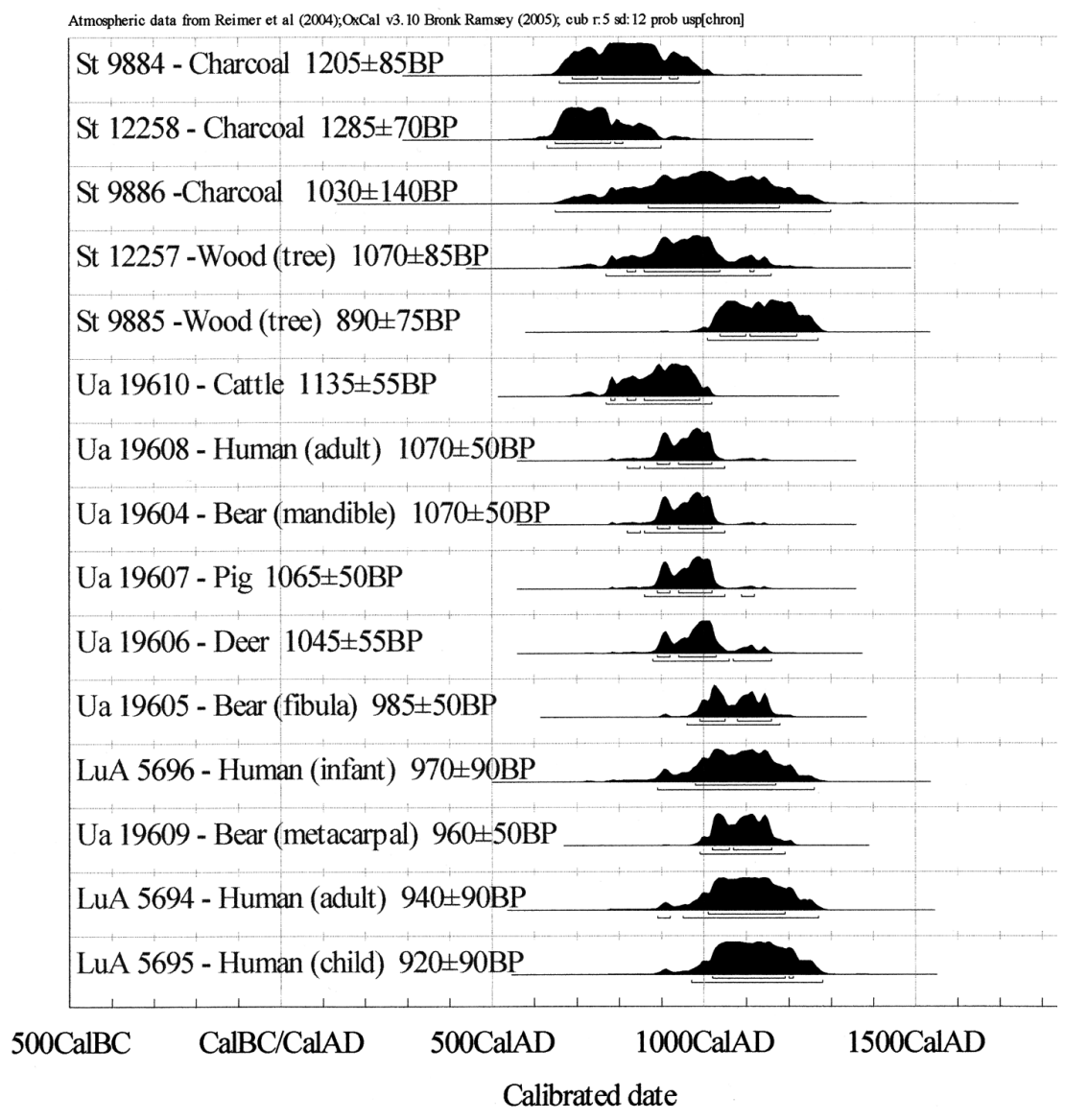

Fig. 2. Radiocarbon dating of charcoal: wood from birch tree and bones from the choir in Frösö Church.

to Behrensmeyer (I978), identification of trampling follows Olsen and Shipman (I988), and gnawing and butchering marks have been identified based on characteristics described in Blumenschine et al. (I996).

\section{RESULTS}

\section{The chronology}

Radiocarbon dating of the animal bones indicates that the sacrifices and depositions took place during the late Viking Age (end of Ioth to early I I th century) (Fig. 2). Based on the radiocarbon dating it cannot be excluded that depositions of animals started already in the early 9th century and continued until the I 2 th century, but this is not likely. 
Rather, the overlap and distribution of dates, together with the homogeneity of the finds in regard to body part distribution, colour and texture of bones, and anatomic refitting of bones, indicate a shorter period. An analysis of the radiocarbon dates of the bones, done by combining all the dates obtained and assuming that they represent a short event using Oxcal 3.I (Bronk Ramsey 2005), gives the result that the bones were deposited between $\mathrm{AD} 980$ and $\mathrm{I0} 25$ with a $95.4 \%$ probability.

Further, the dating of the tree remains shows that the birch tree was still standing when the rituals took place. Two samples of charcoal dated to the 8th and the 9th century indicate earlier activities at the site. Radiocarbon analyses of four bones show that human remains are contemporaneous with the animal bones and not intrusions from later burials in the church. However, three of the radiocarbon dates from human bones have large errors and might be later, from the I 2 th century (Fig. 2). It is also possible that the dates from the human bones are too old due to reservoir effects caused by consumption of freshwater fish from lakes with hard water. This problem has earlier been suggested to be associated with radiocarbon dating of human remains from Västerhus, Frösö (Holm 2006:I I 4f).

\section{Animal remains}

Studies of the taphonomic history are a useful approach in analysing and understanding ritual bone depositions. The aim is to try to reconstruct the chain of events - from the selection of animals for sacrifice, to how the carcasses were processed, to the deposition of the bones including the type of setting and circumstances (Magnell in press).

What is most striking about the find from Frösö Church is the high proportion of bones of wild animals, especially brown bear, as noted earlier (Iregren 1989). At other sites on the island of Frösö that date from the Late Iron Age to the Early Middle Ages, wild animals make up $3 \%$ or less of all bone fragments (Wallin \& Martinsson-Wallin I990; Thilderqvist 2005; Magnell 2004). However, at the settlement of Kyrklägdan, situated on the mainland around Lake Storsjön, $25 \%$ of all bones are from wild animals, mainly elk (Holmgren I985). This shows that hunting was fairly important for the settlements around Lake Storsjön, in contrast to settlements in southern Scandinavia where bones of wild game make up only a small percentage of the NISP.

Since brown bear is a predator with low population density, the species is never frequently found in bone assemblages from settlements of 


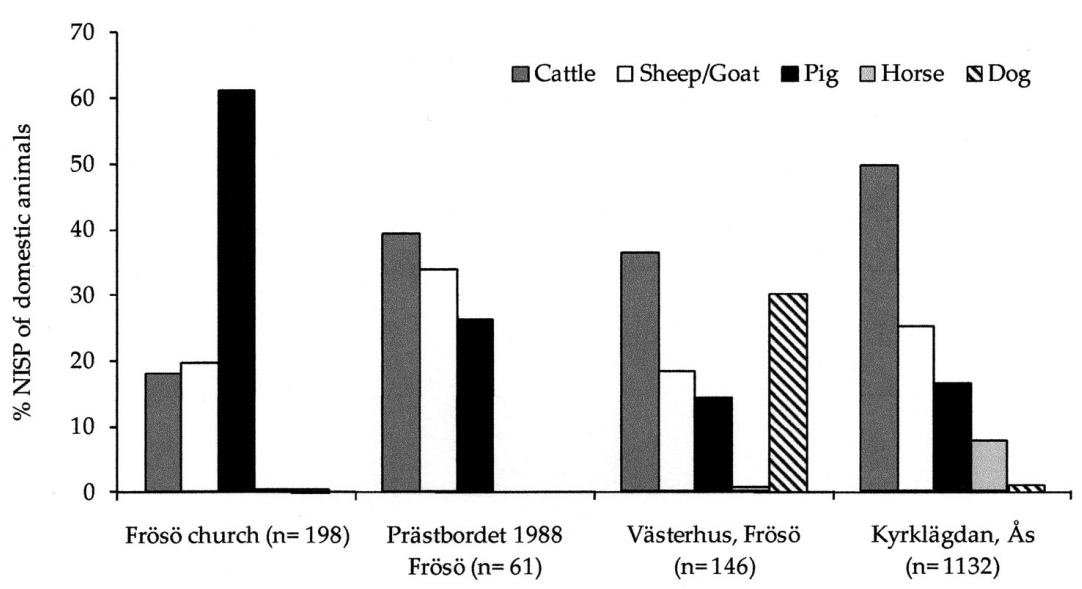

Fig. 3. Frequency of bones (NISP) of domestic animals from Frösö Church in comparison with other sites on or near Frösö: Kyrklägdan, Ås, Migration Period - Middle Ages (Holmgren I98 5 ); Västerhus, Frösö, Early Middle Ages (Thilderqvist 2005); and Prästbordet I988, Frösö, Viking Age (Magnell 2004).

any period (Ekman \& Iregren I984). Thus, there is no doubt that the bear bones from Frösö Church are the result of a selection and that they were brought to the site for a specific purpose.

The relatively high frequency of elk does not reflect the local conditions on Frösö, where the species does not seem to have been hunted frequently, but in a larger regional perspective the abundance of elk bones is not unexpected. The finds of red deer, however, are remarkable. This species is not found at other sites in the region and is not found today in the area around Lake Storsjön. The nearest find of red deer is from Krankmårtenhögen in Härjedalen, but this is dated to the pre-Roman and Roman Iron Age (Ambrosiani et al. 1984:69).

The osteological remains of brown bear and elk include juveniles, but are mainly from adults. Thus, the bones indicate no intentional selection of a specific age group and instead reflect the age composition of the hunted animals.

The occurrence and frequency of the domestic animals are also of interest. It is striking that horse and dog are almost absent, represented only by a single tooth each (Fig. 3). It is clear that the sacrificed domestic animals were the livestock commonly held and slaughtered for meat.

The expected relationship between livestock in a typical Iron Age settlement in middle Sweden would be cattle as the most common livestock followed by sheep/goats and then pigs. An excavation at the site known as Prästbordet 1988 revealed a Viking Age cultural layer only 
I0० m north-east of the choir of Frösö Church, and even though the osteological sample is small it represents the expected frequency of domestic animals in ordinary refuse from the local settlement by the church (Magnell 2004).

The high frequency of pig indicates a clear selection of and preference for pigs as sacrificial animals (Fig. 3). The quantification of the number of individuals accentuates even more the importance of pigs in the rituals at the site (Table I). Pigs had a special importance on Frösö, which is further indicated by finds from the Viking Age cultural layer just outside the churchyard, excavated in I988. A tooth pendant, made from a lower incisor, shows that pigs probably had a symbolic meaning.

Another interesting aspect of the pigs from Frösö is the large tooth size. Two lower third molars from Prästbordet I 988 measured 36.5 and $38.2 \mathrm{~mm}$, which is larger than any pig teeth from Birka or early medieval Lund (Ekman I973; Wigh 200I). In southern Scandinavia, finds of pig teeth of this size from the Viking Age would usually be ascribed to wild boar or rather crossbreeds between wild and domestic pigs. The large teeth cannot be explained as wild boar, since the distribution of that animal in the past has not reached as far north as Jämtland (Ekman \& Iregren 1984). Either the Iron Age pig breeds of middle Sweden were unusually large or the teeth represent imports of crossbreeds used as breeders. Another interesting feature of the molars is lesions of caries, indicating that the pigs had been given an unnatural diet. Interestingly, isotope data of pigs from early medieval Västerhus confirm a diet unusually rich in protein ( $\delta^{13} C_{22} .9 ; \delta^{15} N_{10}$.9) (Iregren et al. 2009: table 5).

All pig bones from Frösö Church, except for a single tooth, come from piglets. Piglets are not uncommon in bone material from Iron Age settlements, but the most frequent age group is almost without exception animals of about I.5-3 years of age. This indicates that piglets (i.e. pigs less than $\mathrm{I} 2$ months) were typically selected to be sacrificed at the blót on Frösö.

The second most common domestic animal is the category sheep/ goat. The bones with morphological characteristics enabling separation of the two species show that sheep were more frequently represented, just as in most Iron Age settlements in Sweden (Table I). The bones of sheep are mainly from lambs, but also adults. Goat is only represented by teeth from a newborn kid. The teeth of dog and horse derive from juvenile animals. Cattle, on the other hand, are represented by osteological remains of newborn calves, subadults, adults, as well 
as old animals. Unfortunately, no bones permitting sexing have been found, and for this reason it is impossible to know whether males or females were preferred as sacrificial animals.

The body part frequency of brown bear, with relatively more postcranial bones than other species, shows that this animal was treated differently (Table I). However, quantification based on MNI (minimum number of individuals) shows that mandibles represent at least seven individuals, bones from the paws four individuals, and bones from the trunk and long bones only two individuals. Anatomical refitting of bones, spatial distribution and ageing further indicate that most of the postcranial bones may originate from two bears, one adult and one subadult (I 8-24 months). Not only body part frequency but also butchering marks prove that single bones or body parts, not complete carcasses of animals, were deposited at the site (Tables I, 2). No animals have been hung in the tree, in contrast to Adam of Bremen's description of the blót at Gamla Uppsala (Adam av Bremen, in Swedish translation I984).

Skinning marks on mandibles, metapodials and phalanges of bear together with missing distal phalanges (the claws) demonstrate that the bear skin has been taken care of (Table I). Butchering marks on mandibles from brown bear, elk and pig show that the lower jaw has been cut from the head. Blackening and cracks on the enamel of teeth from mandibles of pig, sheep and elk indicate exposure to fire, probably from the roasting of the mandible and tongue over fire.

\begin{tabular}{|c|c|c|c|c|c|}
\hline & Gnawing & Trampling & Cut/chop & Burning & Weathering score \\
\hline $\begin{array}{l}\text { Human } \\
\text { (Homo sapiens) }\end{array}$ & & 5 & & & 0.4 \\
\hline $\begin{array}{l}\text { Cattle } \\
\text { (Bos taurus) }\end{array}$ & 3 & & 3 & & 1.6 \\
\hline $\begin{array}{l}\text { Sheep/goat } \\
\text { (Ovis/Capra) }\end{array}$ & 2 & & 2 & 2 & 1.9 \\
\hline $\begin{array}{l}\text { Pig } \\
\text { (Sus domesticus) }\end{array}$ & & & 2 & 3 & 2.2 \\
\hline $\begin{array}{l}\text { Elk } \\
\text { (Alces alces) }\end{array}$ & & & 1 & 1 & 1.9 \\
\hline $\begin{array}{l}\text { Brown bear } \\
\text { (Ursus arctos) }\end{array}$ & 5 & 2 & 61 & & 1.5 \\
\hline
\end{tabular}

Table 2. Number of bones from Frösö Church with evidence of burning and marks from cutting, chopping, trampling, and gnawing by carnivores. Evidence of burning is limited to cracks and blackening of teeth and no bones are calcinated. Weathering score mean of weathering category according to Behrensmeyer (I978). 
The high occurrence of cut and chop marks on bear bones shows that the animals were dismembered in most major joints and that meat was filleted from the bones. Chop marks and breakage patterns on mandibles of bear indicate marrow fracturing (Fig. 4). It is interesting to notice that several of the long bones of bear are unbroken unlike the few postcranial bones of the domestic animals, which all are fragmented.

Three skull bones and two mandibles have chop marks by the alveoli of the canines showing that the fangs have been extracted, probably to be used as tooth pendants or ritual objects. Only bones from the nose part of the skull (premaxilla, maxilla, os palatinum) have been identified and none of the robust bones of the neurocranium. An explanation to this pattern could be that after the extraction of the canines, the bear skulls were removed from the area beneath the birch tree. Interestingly, also no scapula of bear has been found. In the Saami bear graves the skull, mandible and scapula are usually the only bones that are not marrow fractured and damaged. Further, the canines are also in many cases missing in the bear burials (Zachrisson $\&$ Iregren I974:50ff). Maybe the bear skulls and scapulae have been used as ceremonial trophies.

Gnawing marks from carnivores occur on a few bones and show that the bones to a small extent have been exposed to scavengers (Table 2). The low frequency of bones with gnawing marks could be interpreted as an indication of some kind of prevention, such as an enclosure to make the bones less accessible to scavengers.

Weathering on the animal bones indicates that the bones had been exposed for a time before they became covered with soil. Bones embedded in the soil are also affected by weathering, but in this case many bones have one more exposed side with longitudinal cracks, which is typical of bones exposed to weathering while lying on the ground. The higher degree of weathering on bones from pig in comparison with bear can most likely be explained by the fact that the pig bones come from juvenile animals with a more porous bone surface, which is more sensitive to weathering (Table 2). Since weathering is dependent on different factors like exposure to sunlight, moisture and temperature, as well as the morphology of the bones, it is difficult to determine how long a time the bones had been exposed. It usually takes a few years before any traces of weathering appear, and bones do not start to fall apart from weathering before at least a decade of exposure (Lyman I994:365). This means that the bones most likely had been lying be- 

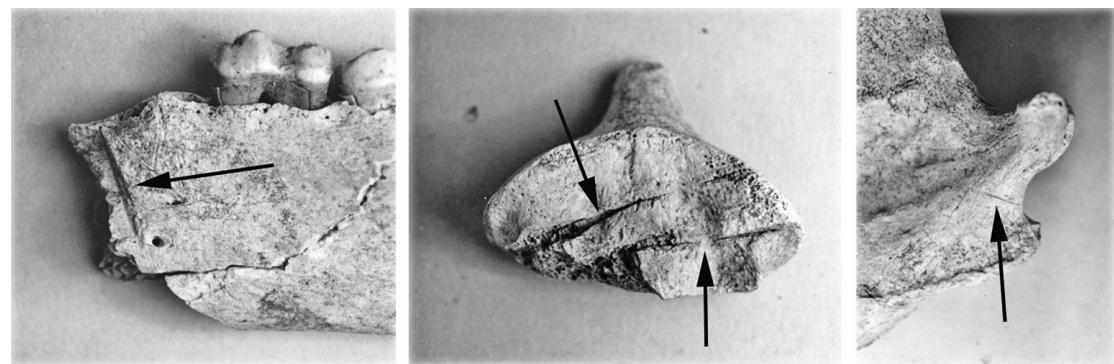

Fig. 4. Chop and cut marks on bones of brown bear from dismembering. Left: chop mark on corpus mandibulae. Middle: chop marks on ventral axis. Right: cut mark by processus articularis on mandibula.

neath the birch tree for several years before being covered by humus from decomposing leaves and organic refuse.

The construction of a church over the layers with bones most likely protected the remains and resulted in the preservation of the tree and bones. If this had not happened the tree would not be preserved at all and the bones would be more fragmented and less well preserved, making the material more difficult to interpret.

\section{Human sacrifice?}

The radiocarbon dating shows that the human bones are more or less contemporaneous with the animal bones (Fig. 2). The 29 human bones originate from at least two adults, one child aged about $3-5$ years, and one infant aged $0-6$ months. The adults are represented by four ribs and $\mathrm{I}_{3}$ bones from the hands and feet, while only nine bones from the trunk of the child have been found (thoracic vertebrates, ribs, pelvis and scapula). The infant is represented by parts of the skull (os occipitale), scapula and tibia (Table I, Fig. 5).

On the human remains there are no traces of burning, cut marks or gnawing marks to indicate how the corpses had been treated and whether the individuals had been killed or mutilated. The human bones show distinctly less weathering in comparison with the animal bones, indicating different treatment of the human bones (Table 2). Most likely the human bones had been deposited in the ground relatively quickly. Further, the human bones were found in a limited area in the north-eastern part of the choir, an area with only a few animal bones. These animal bones are also less weathered and have a different yellowwhite colour. They have been interpreted as later than the other animal bones, perhaps from the time of the construction of the stone church. 

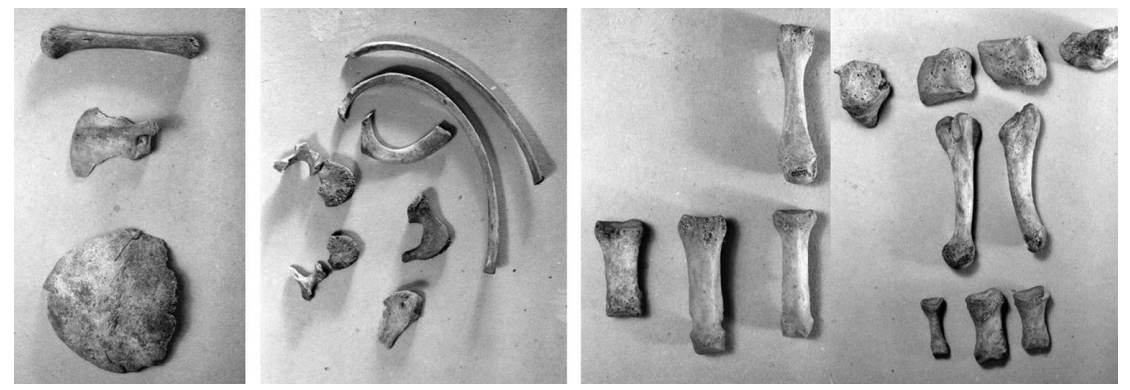

Fig. 5. Human remains in the choir of Frösö Church.

Left: infant. Middle: child 3-5 years. Right: adults.

It cannot be excluded that the human bones originate from sacrificed humans, but there is nothing to indicate this apart from their occurrence in the same layer as the animal bones. The low degree of weathering makes it unlikely that the remains represent bones falling from decomposing bodies hung in the tree; rather, the bones had been deposited in the ground. The exceptionally well-preserved bones of the infant and child also indicate that the human remains had been deposited.

An alternative interpretation is that the bones represent graves, perhaps from the time just after the sacrifices ended. Later, possibly during the construction of the church, the graves were found and exhumed so that the individuals could be buried elsewhere. Phalanges, carpal and tarsal bones are often missing among human remains, even in archaeological excavations. Bones of infants and children may have been mistaken for animal bones, which often happens when people are not trained in human anatomy.

To summarize, the human bones could be the remains of human sacrifice, but it cannot be excluded that the bones originate from graves disturbed during the construction of the church.

\section{The seasons of sacrifice}

In the earlier study, the seasonality of the find was found to be from October to December (Iregren I989:I2I). The new analysis, aided by the development of ageing methodology in recent years, indicates a more complicated picture. Seasonal analysis is in most cases also a matter of interpretation. It is possible from figure 6 to argue that animals were killed throughout the entire year, but the grouping of the seasonal indicators rather suggests that the slaughter was restricted to shorter periods. In seasonal analysis of settlements, the usual proce- 


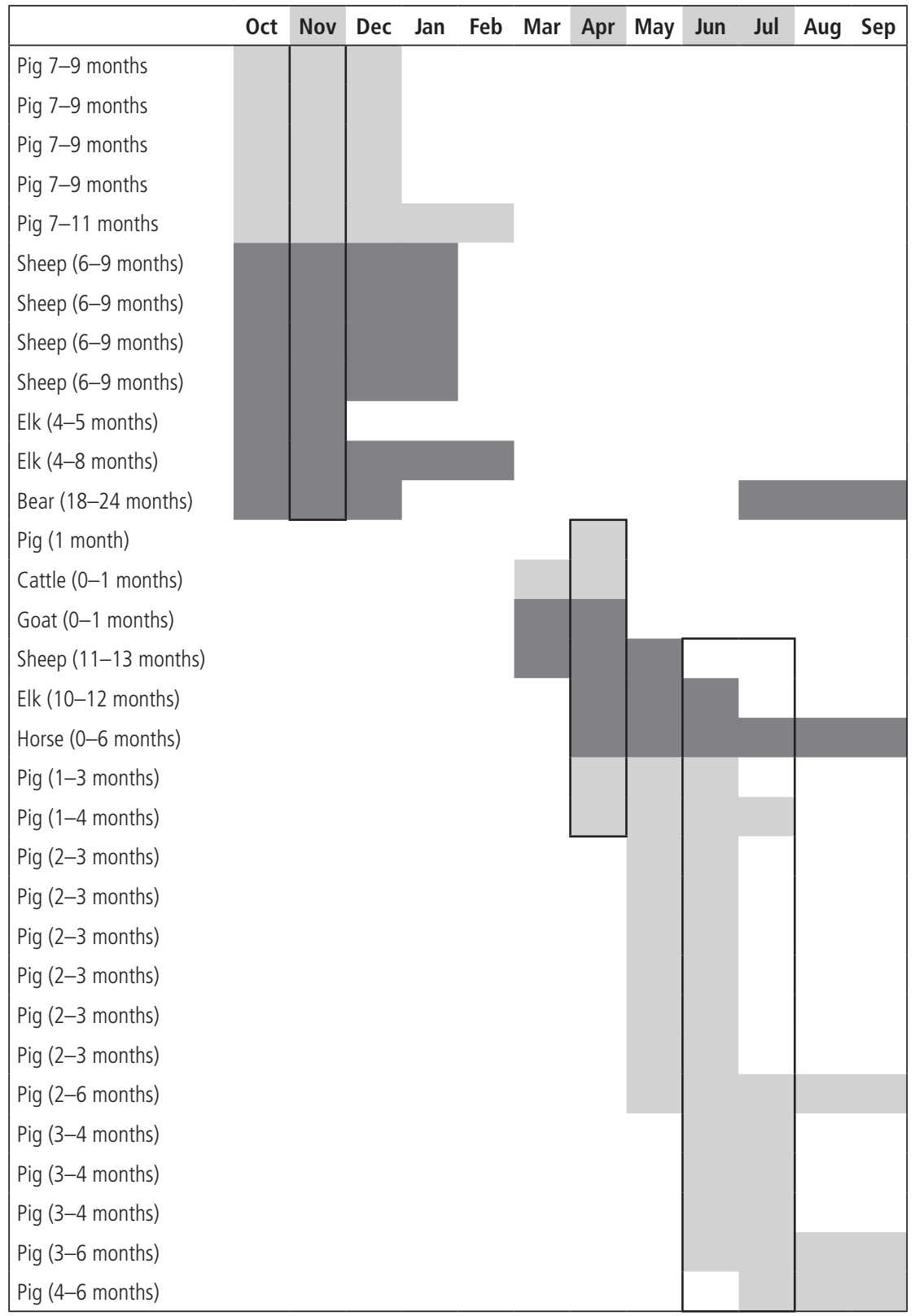

Fig. 6. Seasonality of killing of animals deposited in Frösö Church. Black rectangles indicate the three shortest possible periods of killing. Dark grey shows certain seasonal indicators of animals with limited breeding periods, while light grey shows less certain indicators of animals with unrestricted breeding, but most plausibly with births in spring. 
dure is to determine the shortest possible season that the data indicate.

The occurrence of juvenile pigs and sheep indicates slaughtering in the autumn and early winter, while elk have been killed in autumn and bear in summer/autumn (Fig. 6). The clustering of the seasonal indicators suggests that the slaughter of the different species overlapped during a limited period. The shortest possible period would be October or November. Further, newborn cattle, pig and goat together with indicators of juvenile horse and sheep indicate that killing was done in spring, around April (Fig. 6).

Several of the piglets were killed at the age of about three months, which with a presumed birth in early spring would indicate sacrifices during summer, in June or July around the summer solstice (Fig. 6). However, killing in summer is only indicated by pigs, which as mentioned earlier is an uncertain seasonal indicator. If one assumes that pigs during the Viking Age had two litters each year, the first most likely took place in early spring and the next in late summer. If the piglets aged about three months were from the second litter in late summer, the animals would have been killed around November, which is in accordance with the other seasonal indicators of a sacrifice at the beginning of the winter nights.

As a conclusion of the seasonal analysis, it can be said that animals were killed during at least two periods but possibly even three - in autumn, in spring, and possibly around midsummer.

\section{DISCUSSION}

There are reasons to assume that the place of the blót at Frösö was not randomly chosen and that the area of Frösö Church was a sacred site in a mythical landscape. Finds of a deposition of burned bones of mainly juvenile sheep or goat in a pit about Ioo m north of Frösö Church indicate that the place may have been used for ritual activities at least since the 7 th century (Hemmendorff 20I0). The occurrence of fire-cracked stones in the layer beneath the animal bones and the radiocarbon dating of charcoal to the 7 th-9th centuries show early activities at the site.

The radiocarbon dating of the bones suggests that the longest possible period of deposition of animal bones was between c. AD 900 and I050. However, an analysis of the radiocarbon results indicates that the blót probably took place in a relatively short period of 50 years between $\mathrm{c}$. AD 980 and 1030 . The end of the sacrifices around this period is in good accordance with other evidence of the Christianization 
of Jämtland. The end of depositions of bones at the site corresponds with the last pre-Christian graves in the area from I020-IO3O and with the erection of the rune stone at Frösö in 1060-90 on which it can be read that Jämtland was Christianized by Östman, the son of Gudfast (Gräslund I996:22; Welinder 2003:5 I3). The church was most likely built during the second half of the I 2 th century (Holm 2006:I32). This indicates that at least a century passed between the end of the depositions of animal bones and the construction of the stone church.

It is not possible to tell whether the blót took place every year or every ninth year in an eight-year cycle as in the description of the blót in Lejre and Gamla Uppsala (Nordberg 2006:82ff). That the sacrifices only took place at specific times such as during years of crop failure or unusually successful hunting seasons or good harvests is also possible, but most likely the bones originate from recurrent rituals.

If animals were sacrificed three times a year in a period of fifty years, should not the amount of bones from the site have been more extensive? Not necessarily. First, only a limited area has been excavated and the taphonomic loss of bones must have been great. The recovered bones most likely represent only a small sample of all animals sacrificed and deposited at the site.

According to the written sources a blót and sacrifice of animals took place in autumn around the 2oth of October (chronology according to Gregorian calendar) at the beginning of "the winter nights". This was one of the four periods into which the year was divided according to the pre-Christian calendar, and it possibly also marked the beginning of a new year. The blót in "the winter nights" is the pre-Christian ceremonial feast that is best known from the written sources. This blót was also called disablot and was dedicated to diser, female fertility deities. There are also sources that tell of blót dedicated to Freyr in "the winter nights" (Nordberg 2006:77).

The seasonal indicators of autumn are piglets, lambs and elk, and these animals possibly were killed at the disablot at the beginning of the winter nights. The blót was probably a celebration of a past prosperous year or alternatively a way to ensure that the coming year would be good, and was dedicated to Freyr and other fertility deities. The fact that the feast coincided with what was considered, at least since the Middle Ages, as the month of slaughter is probably not a coincidence but instead a fusion of cult and farming practice.

The deposition of bones of elk and possibly also bear killed in late 
autumn could be the result of rituals using the remains of the firstkilled animals of the hunting season, in order to ensure good hunting. Whether the hunting during the Viking Age was controlled by rules and traditions is not certain, but it is likely. In the later medieval provincial laws, such as Dalalagen, it is mentioned that the hunting season starts with the winter nights and ends with the summer nights (Nordberg 2006:39). According to the Old Norse calendar the summer nights start at the end of April, and interestingly a seasonal indicator of elk points toward killing in late spring/early summer. Possibly this deposition is the result of offerings at the end of the hunting season.

The seasonal analysis indicates no evidence of killing of animals in January and around midwinter night, which according to the Old Norse calendar occurred one month after the winter solstice. The midwinter blót is the pre-Christian sacrifice that is most well known among the general public, and the Uppsala blót has earlier been described as being held at midwinter, but this is most likely incorrect. It rather took place at the vernal equinox at the end of March (Nordberg 2006:I 56 ).

The seasonal indictors of animals killed in spring, from March to April, possibly represent a disablot like the famous sacrifices in Uppsala, performed in order to ensure good crops and good reproduction in livestock. The newborn animals in spring were possibly specifically selected animals, such as the first-born animals of the season, sacrificed in order to ensure that the coming season would be good.

Pigs killed in summer indicate sacrifices around the summer solstice. A blót at midsummer is described in the written sources, but less frequently and less specifically than the sacrifices in the winter nights or the disablót in early spring (Nordberg 2006).

A large variety of both typical farm animals and wild game seem to have been involved in the rituals, but pig and brown bear clearly have had special importance. Pigs may have been specifically selected on account of the fertility symbolism as well as the association between pigs and fertility deities like Freyr, as mentioned in the written sources (Näsström 200I:I6I).

There is no evidence to show how the animals were killed. It is reasonable to assume that domestic animals were slaughtered near the birch tree, while wild animals most likely were killed at a distance from the site. Frösö is too small an area to have a local population of brown bear, and bones of this species must have been transported to the site from hunting grounds around Lake Storsjön. Elk, on the other hand, 
may originate from animals hunted on the island as well as in areas farther away from Frösö. The high frequency of mandibles of bear and especially elk might be explained by the circumstance that often only parts of the animals were transported to the site for deposition (Table I). But since domestic animals are also foremost represented by mandibles and a few postcranial bones, the selection of jawbones must depend on other factors as well. The mandible with its characteristic morphology may have served as a suitable symbol for the sacrificed animal. Depositions of mandibles are a well-known phenomenon from the Mesolithic, Neolithic and Iron Age in Scandinavia (Ekman I974:2 I4f; Noe-Nygaard \& Richter I988; Rudebeck 20IO:I 58 ; Magnell in press).

The blót was not only a religious and sacred act, but also an important social event. Butchering marks show that the carcasses of the animals have been utilized and consumed in a feast. The intense utilization of the carcasses indicates that large groups of people participated in the feast and all should have their share of the sacred meals.

The cult leaders and custodians of the blót were probably closely connected to the local elite on Frösö, and the blót served as an occasion to invite allies and to host a ceremonial feast for the public. To offer meat of bear and piglet to the guests could be a way for the cult leaders of the blót to show generosity. Due to ecological factors, pig breeding was less extensive in the northern parts of Scandinavia than in the southern parts and pork was probably a coveted delicacy.

The bones of wild game and especially bear together with the birch tree have been interpreted as a Saami influence or a creolization, a fusion of Old Norse and Saami ritual practices (Näsström I996:77; Welinder 2008: 90ff). Bear was considered sacred by the Saami, and rituals such as bear burials are examples of this (Zachrisson \& Iregren 1974). In Saami cosmology the world tree that connected the different worlds was also a birch tree (Hultcrantz I996).

It is clear that the bear has been treated differently from the other animals as there are body parts from all body regions, while other species are almost only represented by mandibles. However, the treatment of the bear bones from Frösö differs in many ways from the Saami bear burials, since the bones were mixed with other species and also were not arranged in a pile with the skull and scapula in anatomic positions. Further, the mandibles are marrow fractured (Iregren I989: I30). Large parts of the skulls and the scapulae are missing from the Frösö find, which could be the result of some kind of special treatment of these 
body parts, which are important in the Saami bear rituals.

Bear may also have had a prominent position due to the fact that bear skin most likely was an important status commodity for the elite in Jämtland in the trade and contact with other regions where the supply of bear skins was limited. Cut marks and missing distal phalanges show that the bear skins were taken care of and not deposited by the tree.

Further, ritual consumption of bear meat in order to acquire the power of the animal is also a possibility in regard to the Viking Age warrior culture. In Saxo Grammaticus' chronicle Gesta Danorum, stories about heroes killing bears occur and also a custom of drinking bear blood in order to transmit the power of the animal (Nordenram 200I). The consumption of blood and other body parts of the felled prey can be considered to be an almost universal behavior among hunters in various cultures (Magnell 2006:83).

The birch tree has probably played an important role in the rituals. Mandibles were used in the rituals and probably represented the sacrificed animals and were deposited on the ground by the tree as the gods' share. It is only possible to speculate whether blood and cooked food were used in the rituals. The tree probably functioned as a mediator or threshold between the world of humans and the divine worlds. The occurrence of bones of animals from the mythology of the world tree Yggdrasil, like deer and squirrel, could have been used in ritual staging of the mythology in a symbolic transformation of the tree into the world tree (Iregren I989:I30).

Human remains are more or less contemporaneous with the sacrificed animals, but they are still not clear evidence of human sacrifices. The taphonomic analysis indicates different treatment of the human remains in relation to the animal bones. After the blót had ceased at the site it is possible that the area was used for burials in a transition phase between its use as a pre-Christian cult place and the erection of the church. The human bones could represent missed remains of exhumed graves found during the construction of the stone church.

\section{CONCLUSIONS}

The find from Frösö Church is a unique source for the understanding of the Old Norse blót, not only because of the preservation of osteological material and tree remains. The find is also special in the sense that it reflects specific environmental conditions and rituals in Viking Age 
Jämtland that cannot be directly transferred to other regions in Scandinavia. It is important to consider that the Old Norse ritual practices most likely varied among places and regions due to local conditions and traditions, but also over time.

The bones from Frösö Church both verify and refute written sources about the blót. The seasonal analysis seems to confirm different aspects of the annual festival cycle with blót at the start of the winter nights in the autumn and a disablot in spring.

According to the written sources horse had a prominent role as a sacrificial animal, but horses did not seem to be important in the blót on Frösö. Further, the analysis also shows no evidence of carcasses hung in the tree as in the description of the blót in Gamla Uppsala. This does not mean that horse in other rituals, at other places, was not important and that sacrificed animals were not hung in trees in Gamla Uppsala, but rather it shows that one should be careful about using the written sources as a model of how blót was performed. Blót was probably a highly diversified and complex event.

The animal bones from Frösö Church give us unique knowledge of how the Old Norse blót was practiced and also exemplify how useful osteological remains can be in studies of ritual practice. This study also emphasizes the importance of detailed taphonomic analysis in order to understand and interpret ritual depositions of bones.

Ola Magnell, University of Lund, Department of Archaeology and Ancient History, Box II 7, 22 I oo Lund, Sweden 


\section{ACKNOWLEDGEMENTS}

We would like to thank Ove Hemmendorff, Jamtli, for practical issues and discussions, and Olof Holm for comments on the manuscript. Financial support from Landsprosten Erik Anderssons minnesfond and the Swedish Research Council have made the study possible.

\section{REFERENCES}

Adam av Bremen. Historien om Hamburgstiftet och dess biskopar. Translation to Swedish by Svenberg, E. I984. Stockholm: Samfundet Pro fide et christianismo.

Ambrosiani, B., Iregren, E. \& Lahtiperä, P. I984. Gravfält i fångstmarken. Undersökningar av gravfälten på Smalnäset och Krankmårtenhögen, Härjedalen. Stockholm: Riksantikvarieämbetet och Statens Historiska Museer.

Andersson, K. I998. Sakralt eller profant - ett tolkningsförslag till det osteologiska materialet från Tibble, Litslena sn. In: Andersson, K. (Ed.). Suionum Hinc Civitates. Nya undersökningar kring norra Mälardalens äldre järnålder. Pp. 239-262. Uppsala: Department of Archaeology and Ancient History, Uppsala University.

Andrén, A. 2004. I skuggan av Yggdrasil. Trädet mellan idé och realitet i nordisk tradition. In: Andrén, A., Jennbert, K. \& Raudvere, C. (Eds). Ordning mot kaos. Studier av nordisk förkristen kosmologi. Pp. 389-430. Lund: Nordic Academic Press.

Behrensmeyer, A. K. I978. Taphonomic and ecologic information from bone weathering. Paleobiology. Vol. I46. Pp. 473-578.

Berg, J. I986. Kohållning i bondemiljö. Ur några tidiga mjölkningsjournaler. In: Biörnstad, A. (Ed). Husdjuren och vi. Fataburen I986. Pp. I I I-I I 8. Stockholm: Nordiska museet.

Blumenschine, R. J., Marean, C. W. \& Capaldo, D. C. I996. Blind Tests of Interanalyst Correspondence Accuracy in the Identification of Cut Marks, Percussion Marks and Carnivore Tooth Marks on Bone Surfaces. Journal of Archaeological Science. Vol. 23. Pp. 493-507.

Boessneck, J., Muller, H-H. \& Teichert, M. I964. Osteologische Unterscheidungsmerkmale zwischen Schaf (Ovis aries Linné) und Ziege (Capra hircus Linné). Kühn-Archiv. Vol. 78. Pp. I-I 29.

Brink, S. I990. Cult sites in Northern Sweden. In: Ahlbäck, T. (Ed.). Old Norse and Finnish Religions and Cultic Place-Names. Pp. 458-489. Åbo: The Donner Institute for Research in Religious and Cultural History.

Brink, S. 2004. Mytologiska rum och eskatologiska föreställningar i det vikingatida Norden. In: Andrén, A., Jennbert, K. \& Raudvere, C. (Eds). Ordning mot kaos. Studier av nordisk förkristen kosmologi. Pp. 29I-3 I 6. Lund: Nordic Academic Press.

Bronk Ramsey, C. 2005. OxCal Program v.3.I. Oxford: Oxford Radiocarbon Accelerator Unit.

Brown, W. A. B., Christofferson, P. V., Massler, M. \& Weiss, M. B. I960. Postnatal tooth development in cattle. American Journal of Veterinary Research. Vol $2 \mathrm{I}$. Pp. 7-34.

Carlie, A. 2004. Forntida byggnadskult. Traditioner och regionalitet i södra Skandinavien. Stockholm: Riksantikvarieämbetet. 
Carter, R. \& Magnell, O. 2007. Age estimation of wild boar (Sus scrofa) based on molariform mandibular tooth development and its application to seasonality at the Mesolithic site of Ringkloster. In: Albarella, U., Dobney, K., Ervynck, A. \& Rowley-Conwy, P. (Eds). Pigs and Humans. I0,00o Years of Interaction. Pp. I97-2 17. Oxford: Oxford University Press.

Clunies Ross, M. I996. Hedniska ekon. Myt och sambälle i fornnordisk litteratur. Gråbo: Anthropos.

Clunies Ross, M. 2002. Närvaron och frånvaron av ritual i norröna medeltida texter. In: Jennbert, K., Andrén, A. \& Raudvere, C. (Eds). Plats och praxis -studier av nordisk förkristen ritual. Vägar till Midgård 2. Pp. I3-30. Lund: Nordic Academic Press.

Dahlander, G. I916. Handbok i smådjursskötsel. D. 2, Getskötsel. Stockholm: Norstedts.

Ekman, J. I973.Early Mediaeval Lund - the fauna and the landscape. Archaeologica Lundensia V. Lund: Kulturen.

Ekman, J. I974. Djurbensmaterialet från stenålderslokalen Ire, Hangvar sn, Gotland. In: Janzon, G. O. Gotlands mellanneolitiska gravar. Pp. 2 I 2-246. Stockholm: Stockholm University.

Ekman, H., Hermansson, N., Pettersson J O., Rulcker, J., Stéen, M. \& Stålfeldt, F. 1992. Älgen. Djuret, skötseln och jakten. Spånga: Svenska jägareförbundet.

Ekman, J. \& Iregren, E. I984. Archaeo-zoological Investigations in Northern Sweden. Early Norrland 8. Stockholm: Kungl. vitterhets historie och antikvitets akademien.

Fabech, C. I991. Booty sacrifices in southern Scandinavia: A reassessment. In: Garwood, P., Jennings, D., Skeates, R. \& Toms, J. (Eds). Sacred and Profane. Proceedings of a Conference on Archaeology, Ritual and Religion. Pp. 88-99. Oxford: Oxbow Books.

Fägerborg, E. I986. Husdjurens Bellman. Om getter och getskötsel. In: Biörnstad, A. (Ed). Husdjuren och vi. Fataburen I986. Pp. I23-I32. Stockholm: Nordiska museet.

Gräslund, A.-S. I996. Kristna inslag i Jämtlands vikingatid. In: Brink, S. (Ed). Jämtlands kristnande. Pp. 2 I-44. Uppsala: Lunne böcker.

Hemmendorff, O. 20I0. Långsiktigt hållbara lokaliseringar. Platser för kult och makt på Frösön. Arkeologi i Norr. Vol. I 2.

Hildebrandt, M. 1989. Frösö kyrka på hednisk grund. In: Hemmendorff, O. (Ed). Arkeologi i fjäll, skog och bygd 2. Järnålder-medeltid. Pp. I 53-166. Östersund: Jämtlands läns museum.

Holm, O. 2006. The dating of Västerhus cemetery. A contribution to the study of Christianization of Jämtland. Current Swedish Archaeology. Vol. I 4. Pp. Io9I42.

Holmgren, Å. I 985 . Analys av benmaterialet från fornlämning 45 Ås sn, Jämtland. Appendix C. In: Olausson, M. (Ed.). Kyrklägdan $i$ Ås. Arkeologisk undersökning av en boplats från folkvandringstid till medeltid. Appendix C. Östersund: Jämtlands läns museum.

Hultgård, A. I997. Från ögonvittnesskildring till retorik. Adam av Bremens notiser om Uppsalakulten i religionshistorisk belysning. In: Hultgård, A. (Ed.). Uppsala och Adam av Bremen. Pp. 9-50. Nora: Nya Doxa.

Hultcrantz, A. I996. A new look at the world pillar in Arctic and sub-Arctic religions. In: Pentikäinen, J. Y. (Ed). Shamanism and Northern Ecology. Pp. 3 I-49. Berlin: Mouton de Gruyter.

Insulander, N. 1956. Svensk fårskötsel. Stockholm: LTs förlag. 
Iregren, E. I989. Under Frösö kyrka - ben från en vikingatida offerlund. In: Larsson, L. \& Wyszomirska, B. (Eds). Arkeologi och religion. Pp. I I9-I33. Lund: Arkeologiska institutionen, Lunds universitet.

Iregren, E. I997. Why animal bones in human graves. An attempt to interpret animals present in Iron Age cremations in Sweden. In: Smits, E., Iregren, E. \& Drusini, A. D. (Eds). Cremation Stuides in Archaeology. Pp. 9-32. Padova: Logos Edizioni.

Iregren, E., Alexandersen, V. \& Redin, L. 2009. Västerhus. Kapell, kyrkogård och befolkning. Stockholm: Kungl. Vitterhets Historie och Antikvitets Akademien.

Jakobsson, M. I997. Burial layout, society and sacred geography. A Viking Age example from Jämtland. Current Swedish Archaeology. Vol. 5. Pp. 79-98.

Janson, H. I998. Templum nobilissimum.Adam av Bremen, Uppsalatemplet och konfliktlinjerna i Europa kring år I075. Göteborg: Historiska institutionen, Göteborgs universitet.

Jennbert, K. 2002. Djuren i nordisk förkristen ritual och myt. In: Jennbert, K., Andrén, A. \& Raudvere, C. (Eds). Plats och praxis-studier av nordisk förkristen ritual. Vägar till Midgård 2. Pp. I05-I33. Lund Nordic Academic Press.

Jones, G. G. 2006. Tooth eruption and wear observed in live sheep from Butser Hill, the Cotswold Farm Park and Five Farms in the Pentland Hills, UK. In: Ruscillo, D. (Ed). Recent Advances in Ageing and Sexing Animal Bones. Proceedings of the 9th ICAZ Conference, Durham 2002. Pp. I 88-202. Oxford: Oxbow Books.

Lauwerier, R. C. G. M. I983. Pigs, piglets and determining the season of slaughtering. Journal of Archaeological Science. Vol. Io. Pp. 483-488.

Larsson, J. 2009. Fäbodväsendet I 550-I920. Ett centralt element $i$ Nordsveriges jordbrukssystem. Östersund: Jamtli förlag.

Lemel, J. I 999. Populationstillväxt, dynamik och spridning hos vildsvinet, Sus scrofa, i mellersta Sverige. Slutrapport. Uppsala: Forskningsavdelningen, Svenska jägareförbundet.

Lindeblad, K. \& Nielsen, A-L. I997. Kungens gods i Borg. Om utgräuningarna vid Borgs säteri: arkeologisk slutundersökning, Borgs säteri 6702, RAÄ 276, Borgs socken, Norrköpings kommun, Östergötland. Lindköping: Riksantikvarieämbetet.

Lyman, R. L. I994. Vertebrate Taphonomy. Cambridge: Cambridge University Press.

Magnell, O. 2004. Djurben från vikingatida lager nordväst om Frösö kyrka. Unpublished osteological report.

Magnell, O. 2006. Tracking wild boar and hunters. Osteology of wild boar in Mesolithic South Scandinavia. Lund: Department of Archaeology and Ancient History, Lund University.

Magnell, O. Submitted. "Age assessment of moose based on mandibular molariform tooth development. Alces.

Magnell, O. In press. Sacred Cows or Old Beasts? A taphonomic approach to studying ritual killing with an example from Iron Age Uppåkra, Sweden. Pluskowski, A. (Ed.). Animal Ritual Killing: European Perspectives. Oxford: Oxbow Books.

Nathorst, H. I877. Nötboskapsskötsel, efter dess nuvarande ståndpunkt. Stockholm: F \& G Beijers förlag.

Nilsson, L. 2003. Blóta, Sóa, Senda. Analys av djurben. In: Söderberg, B. (Ed.). Järrestad. Huvudgård i centralbygd. Pp. 287-308. Stockholm: Riksantikvarieämbetet.

Nilsson, L. 2009. Häst och hund i fruktbarhetskult och blot. Carlie, A. (Ed.). Järnålderns rituella platser. Pp. 8 I-99. Halmstad: Kulturmiljö Halland. 
Noe-Nygaard, N. \& Richter, J. I990. Seventeen wild boar mandibles from Sludegårds Sömosse - Offal or sacrifice? In: Robinson, D. E. (Ed.). Experimentation and Reconstruction in Environmental Archaeology. Symposia of the Association for Environmental Archaeology No. 9. Pp. I75-187. Oxford: Oxbow Books.

Nordberg, A. 2006. Jul, disting och förkyrklig tideräkning. Kalendrar och kalendriska riter i det förkristna Norden. Uppsala: Kungl. Gustav Adolfs Akademien för svensk folkkultur.

Nordenram, A. 200I. Svenska jaktens historia från forntid till nutid. Örkelljunga: Bokförlaget Settern.

Näsström, B-M. I996. Offerlunden under Frösö kyrka. In: Brink, S. (Ed). Jämtlands kristnande. Projekten Sveriges kristnande. Pp. 65-85. Uppsala: Lunne böcker.

Näsström, B-M. 200I. Blot. Tro och offer i det förkristna Norden. Stockholm: Norstedts.

Näsström, B-M. 2006. Fornskandinavisk religion. Lund: Studentlitteratur.

Olsen, S. L. \& Shipman, P. I988. Surface Modification on Bone; Trampling Versus Butchery. Journal of Archaeological Science. Vol. I 5. Pp. 535-553.

Palm, R. 2004. Vikingarnas språk 750-I I00. Stockholm: Norstedts.

Paulsson-Holmberg, T. I997. Iron Age building offerings. A contribution to the analysis of a die-hard phenomenon in Swedish preindustrial agrarian society. Fornvännen. Vol. 92. Pp. I63-I75.

Payne, S. I98 5 . Morphological distinctions between the mandibular teeth of young sheep, Ovis, and goat, Capra. Journal of Archaeological Science. Vol. I2. Pp. I 39-I 47 .

Richter, J. I982. Adult and juvenile aurochs, Bos primigenius Boj. From the Maglemosian site of Ulkestrup Lyng Öst, Denmark. Journal of Archaeological Science. Vol. 9. Pp. 247-259.

Rossdale, P. 1996. Hästavel. Dräktighet, fölning, unga föl. Halmstad: Bokförlaget Spektra AB.

Rudebeck, E. 20IO. I trästodernas skugga. Monumentala möten i neolitiseringens tid. In: Nilsson, B. \& Rudebeck, E. (Eds). Arkeologiska och förhistoriska världar. Fält, erfarenheter och stenåldersplatser i sydvästra Skåne. Pp. 83-25 I. Malmö: Malmö Museer.

Sandegren, F. \& Swenson, J. I997. Björnen. Viltet, ekologin och människan. Spånga: Svenska jägareförbundet.

Sjödin, E. r980. Får. Stockholm: LTs förlag.

Sundqvist, O. 2007. Kultledare i fornskandinavisk religion. Uppsala: Department of Archaeology and Ancient History, Uppsala University.

Thilderqvist, J. 2005. Analys av det osteologiska materialet från den arkeologiska undersökningen vid Västerhus på Frösön 2005. In: Oskarsson, B. Arkeologisk undersökning RAÄ 33 mfl, Västerhus kapell, Frösö sn, Östersunds kn, Jämtlands län. Pp I-23. Östersund: Jämtlands läns museum.

Vikstrand, P. I993. Förkristna sakrala ortnamn i Jämtland. Namn och bygd. Vol. 8I. Pp. 49-84.

Vikstrand, P. 200I. Gudarnas platser. Förkristna sakrala ortnamn i Mälarlandskapen. Uppsala: Institutionen för nordiska språk, Uppsala universitet.

Wallin, P. \& Martinsson-Wallin, H. I990. Osteologisk analys av brända och obrända ben från Frösö kyrkogård, Frösö sn. Östersunds kn. i Jämtland. In: Pagoldh, M. Rapport över arkeologisk undersökning inom Prästbordet I:I, Frösö socken, Östersunds kommun, Jämtlands län. Arkeologiska undersökningar utförda av Jämtlands läns museum 436. Östersund: Jämtlands läns museum. 
Welinder, S. 2003. Christianity, Politics and Ethnicity in Early Medieval Jämtland, Mid Sweden. In: Carver, M. (Ed.). The Cross Goes North. Process of Conversion in Northern Europe AD 300-I300. Pp. 509-530. York: York Medieval Press.

Welinder, S. 2008. Jämtarna och samerna kom först. Östersund: Jamtli.

Wigh, B. 200I. Animal Husbandry in the Viking Age Town of Birka and its Hinterland. Stockholm: Department of Archaeology and Ancient History, Stockholm University.

Zachrisson, I. \& Iregen, E. 1974. Lappish bear graves in Northern Sweden. Early Norrland 5. Stockholm: Kungl. vitterhets historie och antikvitets akademien.

Zeder, M. A. \& Pilaar, S. E. 20IO. Assessing the reliability of criteria used to identify mandibles and mandibular teeth in sheep, Ovis, and goats, Capra. Journal of Archaeological Science. Vol. 37. Pp. 225-242. 


\title{
PRODUCT OR PRODUCTION
}

\section{On the accumulative aspect of rock art at Nämforsen, northern Sweden}

Ylva Sjöstrand

\begin{abstract}
In this article the accumulative aspect of rock art is discussed. In light of the simple fact that we are seeing rock art panels in their final form, questions concerning the interrelation between figures deriving from different time periods are addressed. The author's aim is to draw attention to the long continuity of rock art sites and show how greater awareness of this aspect will affect the way we comprehend this material in general. The continuity of rock art sites is exemplified by means of a case study of Nämforsen, located in the province of Ångermanland, northern Sweden.
\end{abstract}

Key words: accumulation, archaizing, chronology, elk motif, Nämforsen, rock art, sequence analysis, symbol theory

\section{INTRODUCTION}

Since the very beginning of rock art research, these prehistoric images have been seen as the archaeological source material par excellence. The marvellous and aesthetic compositions that we encounter today appear to bear witness to mundane or sacral activities performed in the past. Rock art compositions have consequently been understood as depictions of rituals, cosmologic narratives, hunting methods, or binary oppositions (Hultkrantz I989; Malmer I992; Tilley I99I; Lindqvist I994; 1999; Fandén 1995; Lindgren 200I). In short, the images are often seen as capable of giving detailed information on several different aspects of the prehistoric life-world.

Without denying the significance of rock art, or questioning the im- 
portance of studying this material, I would like to bring up an aspect that puts these interpretations in another light. I am referring to the fact that the beautiful and thought-provoking rock art compositions that $w e$ are seeing did not exist until the last figure was added to the picture. The rock art site, consequently, did not acquire the form we encounter today until the very last figure was carved into the panel. This moment was more or less synchronic with the end of the carving practice, and in this respect the rock carving panels visible today are not showing us what was worshipped so much as what was once abandoned. The prehistoric images that are reproduced in our encyclopaedias of art, in our archaeological theses, or even in the documentation of the sites were thus not visible until the carving practice was over. This remark is possibly regarded as banal, but nevertheless it constitutes a rarely discussed fact within the field of rock art research (for exceptions, see Nordbladh I980; Kaleas I990; Helskog 2000; Hauptman Wahlgren 2002:I 82f; Wriggelsworth 2006). In the way the panels are documented, described and interpreted, it is clear that they usually are seen as coherent pictures.

In this article I will take the fact that rock art is an accumulative phenomenon as my point of departure for an empirical study and a theoretical discussion. My aim is to put attention on the long continuity of rock art sites and show how greater awareness of this aspect will affect the way we comprehend and interpret this material in general. I will exemplify the continuity of rock art by a case study of the carvings at Nämforsen, located in the province of Ångermanland in northern Sweden. Since elk depictions constitute the most frequently explored motif group, I will focus mainly on these images. After having made several visits to the site, I have chosen to base my study on Gustav Hallström's documentation, which still is the only one available. Taking the compositions defined by Hallström (I960) as well as the chronology outlined by Lars Forsberg (1993) as premises, I will examine the process of producing engravings at Nämforsen. The questions addressed in the article are to what extent different phases occur within the same context and whether any patterns can be distinguished in regard to the interference between figures from different time periods.

\section{NÄMFORSEN}

Nämforsen is located in Ådals-Liden parish in the province of Ångermanland, and is one of the largest rock art sites in northern Europe. The 
site has been frequently explored since $\mathrm{I} 705$, and several scholars have documented the panels (Hallström I928; Hallström I960; Lindqvist I994; Baudou 1993; Wennstedt Edvinger 1993; Helskog I999). The most ambitious work is, however, Gustav Hallström's publication from I960, in which the results of more than 50 years of research are presented (Hallström I960; Hallström I967; Baudou I997). Nowadays, Hallström's calculations of figures and motifs have been modified, and today the site is considered to hold more than two thousand figures (Larsson \& Engelmark 2005). The figures are spread out over three islands and over the cliffs of the south river shore, and are, according to Hallström's documentation, placed in 264 different compositions or "subgroups" (Hallström I960:I39). The leading motifs consist of elks, boats and humans, but there are also footprints, birds and fishes at the site.

The age of the rock carvings is of course difficult to establish, and chronology is a topic that never loses actuality. A good indication of the starting point of the carving practice is given by the earliest radiocarbon dates from the settlement "Ställverket", which lies in direct connection to the rock art site. According to these dates, the first carvings may have been made approximately $4200 \mathrm{BC}$. This date correlates with the shoreline displacement datings carried out by Christian Lindqvist and also with the chronology for the carvings at Alta in northern Norway (Helskog I988; Lindqvist I994; Käck 2009; Sjöstrand 20IO). Most scholars agree that the rock carving practice at Nämforsen began at the transition from the fourth to the third millennium BC (Bakka I 976; Hagen I 976; Helskog I988, I 999; Ramqvist I992; Baudou I993; Forsberg 1993; Lindqvist I994; for exceptions, see Malmer I98I; Burenhult I999). Concerning the end of the practice, different hypotheses have been presented. Most of them, however, suggest that the practice of carving phased out slowly and ended at some point during the first millennium BC (see discussion in Hallström 1960; Hagen I976; Baudou I993; Forsberg I993; Ramqvist 1992; Lindqvist I994; Lindgren 200I).

To establish solid and precise dates for both the initial and the final carving may not be possible. All chronological results show, however, that the latest figure on the site was added about three millennia after the first one was carved. The time between the first and the last carving is thus almost the same as the time between the last carving and our present time. Keeping this in mind, it is not surprising that the motifs 
at Nämforsen have changed several times during this extremely long period. In fact, the possibility to see the accumulative aspect of rock art is related to the constant repetition and variation of the leading motifs. If every engraving were unique in motif and style, it would be very difficult - if not impossible - to establish a chronology. The fact that elks are depicted in different styles thus makes it possible to ascertain the span of time at Nämforsen.

What chronologically oriented publications seldom explore, however, is the reason for the stylistic changes in motifs. Time itself does not cause changes to the material culture; it merely makes them visible. Consequently, differences in style can not be explained, only studied, with the help of chronology. When we try to understand the time overlapping the accumulation of rock art at the sites, it is necessary to reflect on the purpose for the stylistic changes. We must also think about the reason for depicting the same motif in different ways, and seek to understand why these different styles appear side by side.

\section{ACCUMULATION, REPETITION, VARIATION}

A good way to explain the stylistic variations in motifs, which accumulated during a long period, is to see them as an indication of differences in significance. This is based on the assumption that a certain motif will receive a modified appearance when new connotations or meanings are ascribed to it (Ortner I979). Just as standardization of logotypes is done when the brand has become well known and consequently associated with altered values and aspects, motifs at Nämforsen were given different attributes or executed in a new carving technique when the concept to which they referred was modified. In order for a new concept to gain significance, a stylistic change, as in the elk, was required to manifest it.

If the supposition outlined above is accepted, the so-called mimetic approach starts to become inadequate (Rosengren 200I, 2002; Sjöstrand in press a; in press b). According to this approach, the meaning of an image is regarded as synonymous with what is being depicted. A figure clearly identifiable as an elk is considered to refer to nothing but this animal. Yet, if the only ambition was to draw an elk, why was this motif altered to such a great degree? Further, why was the same locality used, with the result that this variation became exposed in its clearest light? If these paradigmatic alterations in style had involved a change in carving locality, both the accumulative and multi-stylistic 
aspects would be absent. But since figures depicting the same motif in different ways have been mixed and have interacted with each other at Nämforsen, their differences have been highlighted and exposed in a manner that must be seen as well considered.

The most reasonable theory to explain the combined phenomena of accumulation, repetition and variation at Nämforsen is to admit that the same motif is able to hold various meanings. The different ways of depicting elks thus made them refer to different things. According to this notion, the elk motif is in fact a range of symbols, and intricate meanings could be expressed by relating the different elks to each other. When carving a figure next to another that had been made hundreds of years earlier, a complex symbolic interaction was manifested. Therefore, by studying the accumulative aspect we might be able to reveal how the elk motif was used in this symbolic interplay.

\section{CHRONOLOGICAL PHASES}

Before studying the accumulative aspect of rock art and discussing the symbol-theoretical consequences that come with it, the internal chronology of Nämforsen has to be presented. I have chosen to base my study on the phases outlined by Lars Forsberg, since he studied the differences between elk figures in order to find out if there were stylistic changes related to chronology (Forsberg I 993:202). Forsberg's latent assumptions are therefore similar to mine: the accumulation of rock carvings is a process parallel to the variation and repetition of leading motifs.

By using cluster analyses Forsberg was able to show the existence of four stylistic variations within the elk motif (Forsberg I 993:205ff). To find out if these contained a gradient (an even transition between the styles that can have chronological reasons) he applied multidimensional scalar analysis (MDS) to a selected number of figures. From this statistical operation he could confirm that four types of elk figures could be clearly identified and also that the carving technique must be seen as a chronological gradient (Forsberg I993:222). The results of the statistical analyses confirmed what Christian Lindquist had already suggested, namely that the surface-pecked motifs are older than the ones outlined by contours (Lindqvist I994:2 I 3f). Since only one of Forsberg's four elk types is surface pecked, this must be the earliest. This fact is also important for constructing a relative chronology for the boat motif. Forsberg argued that the surface-pecked boats were older than the contour-pecked ones (Forsberg I 993:2 I 9ff). 


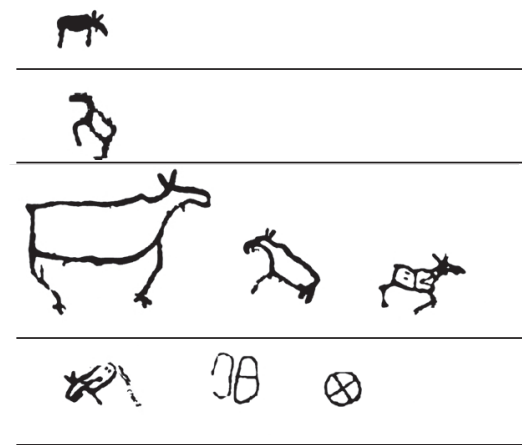

Figure ıa. Forsberg's chronology over the elk motif at Nämforsen. The earliest phase, consisting of surface-pecked elks with straight legs, is shown at the top (examples taken from Hallström's documentation I960).

\section{Terluels}

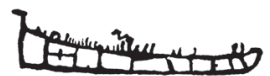

Figure $\mathrm{s}$ b. Examples of the earlier (left) and the later (right) boat type (taken from Hallström's documentation I960).

After establishing that the surface-pecked elks were the oldest type, Forsberg's next question to solve was how the three other types distinguished by the MDS analysis were related to each other in terms of age. This problem was handled by using analogies, further statistical analyses, and studies of carvings that overlapped (Forsberg I 993:2 I9-23I). By using analogies Forsberg was able to show that the chronological sequence at Nämforsen ends with the type of elks that are contour pecked, have short straight legs and body marks. The most important analogy used to verify this was made with the carvings at Norrfors, Umeå parish, Västerbotten. At this locality all the elk figures are executed in this particular contour-pecked style. Norrfors is one of few rock art sites in northern Sweden that can be dated accurately through the study of shoreline displacement (Ramqvist et al. 1985; Ramqvist I988; I992; Forsberg I992). As local curves of shoreline regression indicate that the panels would have been underwater until $2200 \mathrm{BC}$, the initial carving activities must have taken place after this date (Segerström I98I). According to Forsberg, it is plausible that the carvings were made around $2 \mathrm{I} 00 \mathrm{BC}$ and that this date can be used as a guideline for determining the change between phase three and phase four (Forsberg I 993:2 I6). After establishing that the surface-pecked elks are the oldest, while the ones of "Norrfors type" were added at the end, Forsberg's concern was to place the two middle groups chronologically. He did so by study- 
ing how carvings overlap. Since elks belonging to one of the statistical types are overlapping figures of the other types, Forsberg was able to determine the chronological relation between them. As a result of these studies, Forsberg could establish a typology regarding the elk motif at Nämforsen. The first phase is represented by the surface-pecked style. This kind of elk figure has straight legs and is usually surrounded by humans in large compositions (Sjöstrand 20I0). The second phase consists of contour-pecked elks with rectangular bodies, angled legs, and surface-pecked heads. The angled legs continue into phase three, but the elks are then a little larger and also are provided with more details such as mouth markings, body marks, and beards. In the last phase, the elks once again have straight legs. They are very similar to the figures at Norrfors and are extremely stylized and schematic. In this phase, there are also south Scandinavian motifs such as footprints and wheel crosses. The characteristic human figures with triangular bodies (socalled athlete type) are also linked to this phase.

\section{PICTURES IN THE PICTURE - SEQUENCE ANALYSIS}

Now that the chronological background has been outlined, it is time to study how figures from different phases are related to each other. By using Forsberg's chronology it is possible to deconstruct the panels visible today. The definitions of the four phases give us a tool with which to study how new carvings were incorporated in the already existing picture. It can also help us reveal possible patterns regarding the different phases' relation to the pre-existing ones.

In order to exemplify how I use the chronology, and at the same time illustrate the accumulative process that constitutes the object of interest in this article, I have tried to visualize how one of the compositions at Nämforsen possibly appeared before the last figure was added. Figure 2 shows the famous panel "Brådöhällan" as it might have looked during the time of each of Forsberg's four phases. The sequence was created by using an image processing program in which figures were removed according to the phase in which they belonged. It is important to emphasize that these four images were created by removing all of the figures from a certain phase at the same time. They therefore contain the underlying assumption that the panel was only carved at four separate occasions. When looking at the sequence, one must remember that the motifs were added one by one, which means that there exist as many "pictures in the picture" as there are figures 

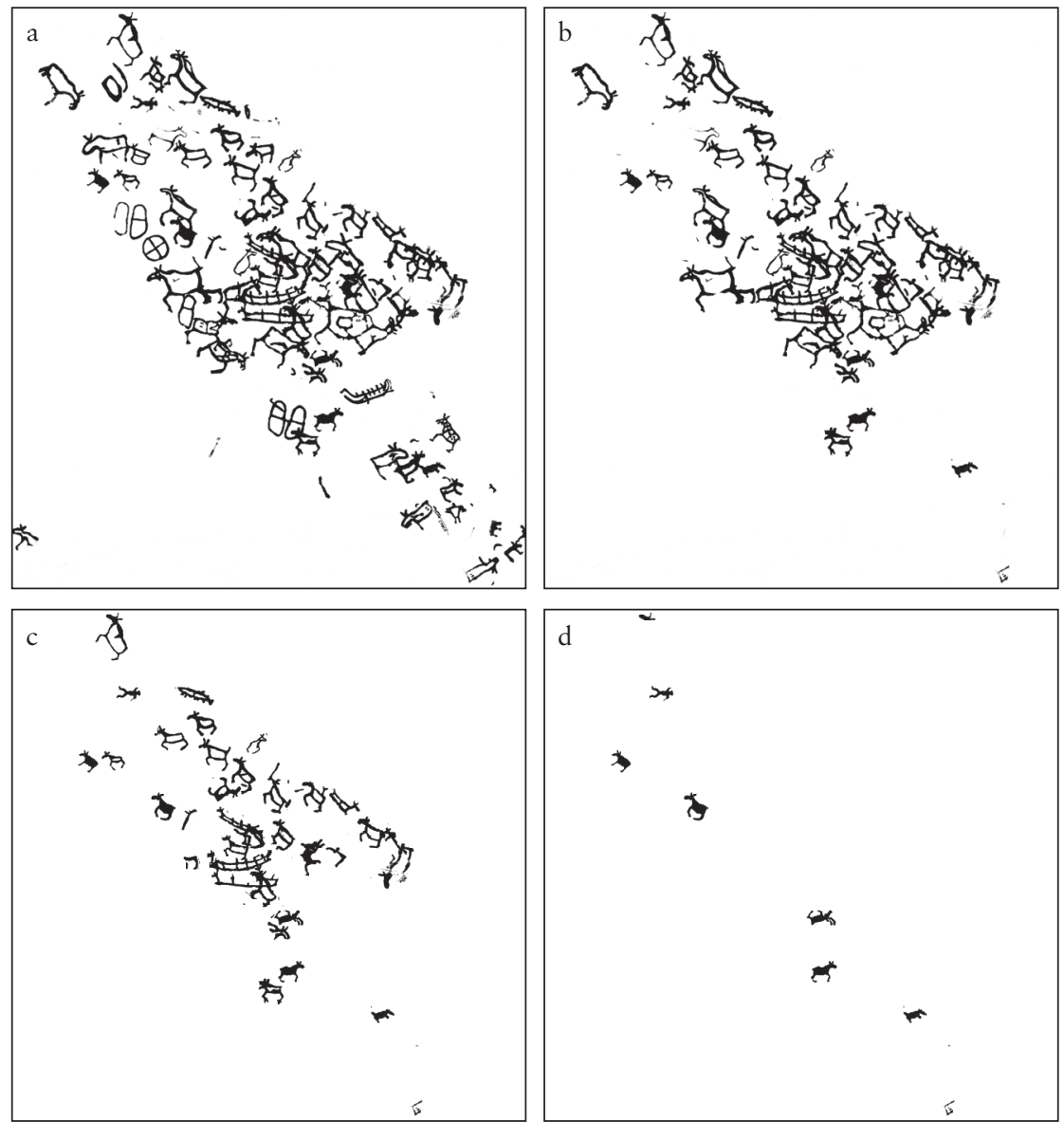

Figure 2. Brådöhällan during a) phase 4 / the appearance it has today, b) phase 3 ,c) phase 2, and d) phase I (based on Hallström I962).

on the panels. As long as this crucial remark is kept in mind, sequence analysis constitutes a useful tool to visualise rock art sites. It helps us realise the fact that the final appearance of the rock art site is just one of countless others, and makes it easier to understand rock art sites as productions rather than products.

Sequence analyses like the one shown in figure 2 have been made statistically for 93 of the 264 compositions defined by Hallström. The studied compositions were selected on the basis of two criteria: that they contained more than one figure, and that they could be clearly identified using Forsberg's chronology. Of the compositions left out of the study, I I 2 contained just one figure and 59 were too fragmented to be chronologically definable. The chosen compositions were carefully 
studied, and the figures occurring in the different phases were registered in a database. The recording of phases was based on an "absence/ presence" criterion. This means that a single occurrence of a figure in a certain phase was enough to regard that phase as being represented in the composition.

The result of this compilation was that $5 \mathrm{I}$ of the 93 compositions $(55 \%)$ contain figures deriving from different periods (fig. $3 \mathrm{a}$ ). This means that the majority of the compositions have changed their visual appearance during the time of the rock carving practice at Nämforsen. Bearing in mind that the limitations that define a certain composition will affect the result, this quantity is probably larger. As I soon came to realise, Hallström had limited his compositions according to similarity and dissimilarity between figures, and had therefore - possibly unwittingly - made them represent only one phase. One example can be seen in the compositions P: I and P: 2 which are found at the south-west edge of Notön. The figures of P: I and P: 2 are located just decimetres apart from each other, but documented as separate compositions (Hallström I960:Pl XIX).

When putting the data together, it became clear that establishing new limitations for the compositions at Nämforsen would benefit the study of an accumulative process at the site. For example, one could define them by using the viewshed tool in a GIS program and thereafter comprehend compositions as "the entire amount of figures visible from a certain point". As many scholars already have pointed out, the materiality of the stone itself is part of the rock art composition, and the figures' placement is greatly dependent on the micro landscape on the panel (Helskog I999; 2004; Bradley 2000; Sognnes I999; 200I; Coles 2004; Goldhahn 2002; Lahelma 2008; Gjerde 2010). To take this important aspect into account when defining compositions would be a possible topic for future research. Unfortunately, the amount of data required for such a task makes it impossible to carry out in this study.

In order to address, at least briefly, the problem of composition limitations I did a sequence analysis based on the three "natural" compositions in which the carvings are placed (fig 3 b). In other words, I looked to see how figures from the different phases were distributed over the three islands of Laxön, Brådön and Notön. The result of this analysis shows that none of these islands is exclusive for one phase only. All these carving spaces have therefore been changed over time.

Studying the accumulative process which has shaped the panels, it 


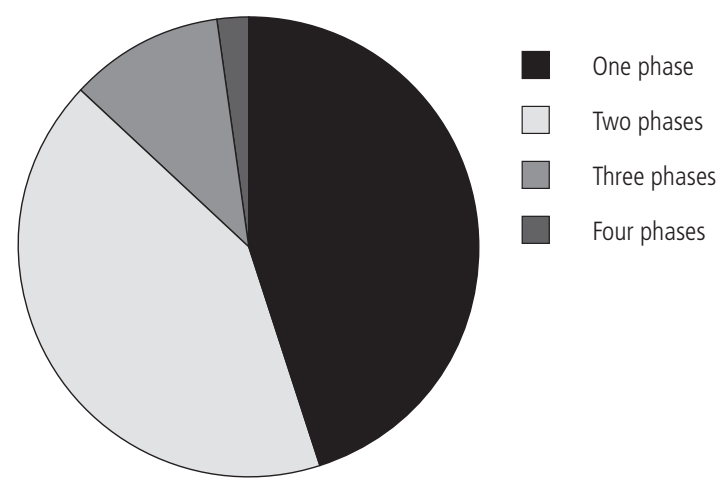

Figure $3 a$. The distribution over compositions containing different numbers of phases at Nämforsen.

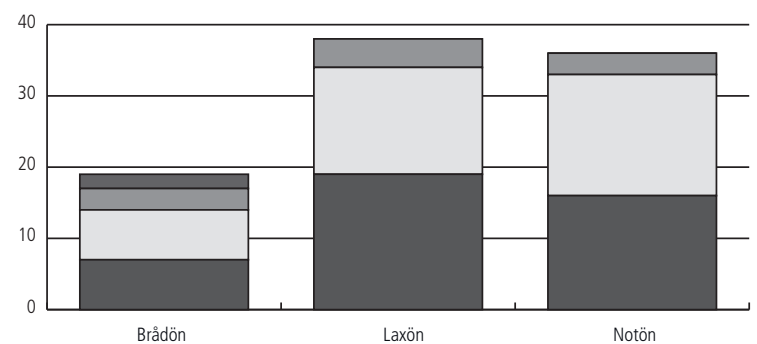

Figure $3 \mathrm{~b}$. The distribution over compositions containing different numbers of phases in the three carving spaces at Nämforsen.

is clear that the motifs are secondary to the process of creating them. This can be supported by a qualitative result of the study of how the phases interact. I have detected plenty of examples of how one motif has been transformed into another by carvings of a later phase, which shows that continuity of rock art sites has affected the motifs themselves (see Myhre 2004 for a similar study). One of these motif modifications is demonstrated in figure $4 \mathrm{a}$, where an early type of boat has been made into elk antlers. The phenomenon of transforming boats into elk antlers is discussed in detail by Antti Lahelma who has observed the same transformative process in the Finnish rock paintings (Lahelma 2008:I I 7). This fact is interesting indeed since antlers are remarkably unusual on elk figures in Fennoscandia (Wennstedt Edvinger 1993).

The body marks of the elks in phase two constitute another interesting example of possible motif modification (fig 4 b). Through this attribute, the elks acquire a shape that makes them look like "footprints on legs". In my opinion it is plausible that these body marks were added at the same time as footprints began to appear within the motif fauna of Nämforsen. A careful study of overlapping carving-lines might be able to confirm or dismiss this hypothesis, but unfortunately I have not been able to carry out such.

When discussing motif transformations related to the accumulative 

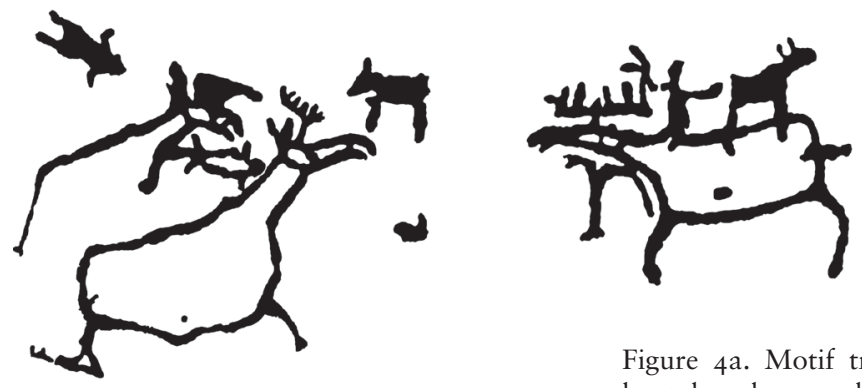

Figure 4a. Motif transformations: the boats have been made to look like elk antlers (after Hallström I960).
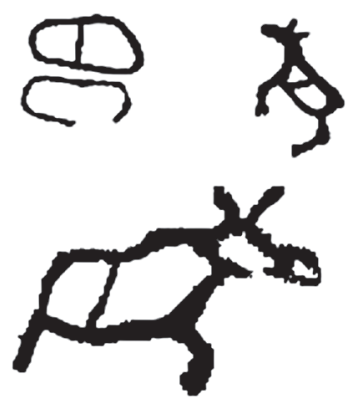

Figure 4 b. Possible motif transformations: elks from the middle phases may have been equipped with ody marks in order to look like footprints (after Hallström I960).

use of rock art sites, the question of visibility needs to be brought up. It is hard to estimate to what extent the old carvings were discernible for those who made figures on the same panels hundreds of years later. Still, the fact that we are able to see them today makes it hard to claim that the prehistoric people were unaware of the fact that they placed their figures over older ones. In my opinion, we have to assume that overlapping and motif transformations were intentional acts, and not reject this important aspect of rock art production as something accidental. However, as Katty Hauptman Wahlgren has suggested, carvings might have been more or less visible depending on how recently they were made (Hauptman Wahlgren 2002:I82-2I6). Since newly engraved figures are shiny and white, it is plausible that compositions were made by re-carving a selected number of figures.

\section{SYMBOLIC INTERACTION - RELATING NEW FIGURES TO OLDER ONES}

As the examples of motif transformations show, the addition of new figures to a pre-existing composition has a huge effect on its visual context. The interaction between phases must consequently be seen as the result of a meaningful action, and the placement of new motifs can not be re- 
Phase two

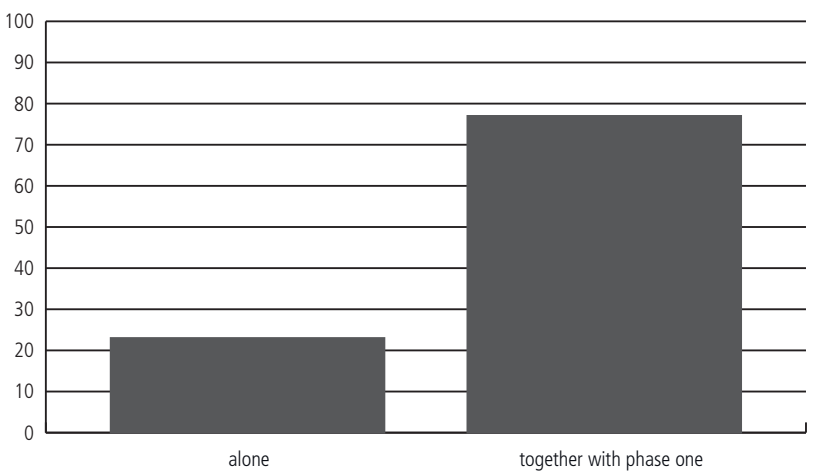

Phase three

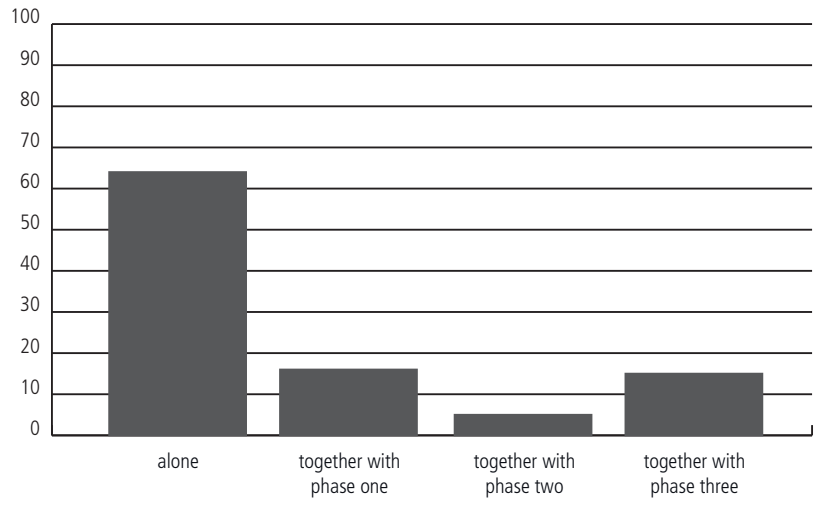

Phase four

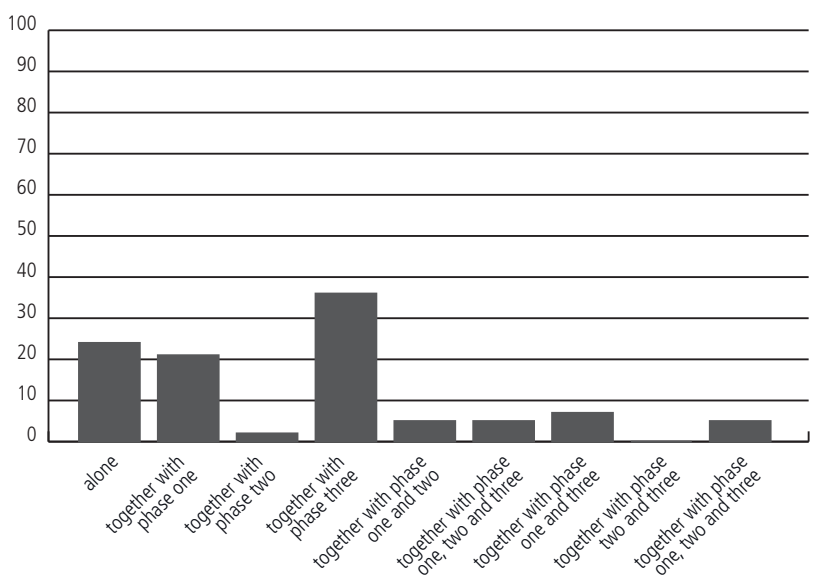

Figure 5. Diagrams showing the combinations of interaction in the four phases at Nämforsen. The values are displayed in percent. 
garded as accidental. To further understand how this symbolic interaction has been carried out, I have studied the particular phases one by one with the aim of discovering which other phases they tend to be involved with. I have also examined to what degree they appear alone (fig. 5).

Since the rock carvers of the first phase at Nämforsen could not relate their figures to any older phase, the first phase was excluded from this study. The compilations revealed, however, that phase two was related to the single earlier phase to a great extent. This is interesting, and definitely must be seen as an indication that connecting new figures with those made previously was part of the carving practice at the time. Important to note is that figures of these two phases tend to gather within large compositions where one of the types usually dominates over the other. Since my study is based on the absence/presence criterion, I can not reach or study the fact that a two-phased composition might hold twenty-five elks belonging to phase one but only one elk from phase two. When it comes to the first two phases of Nämforsen, these kinds of distributions are common, and this needs to be kept in mind (see Sjöstrand 20I0).

If phase two is mainly integrated, phase three shows almost the opposite tendency. The figures belonging to this phase are carved autonomously to $64 \%$. This means that compositions containing just one phase are more common during this period than any other. In cases where the figures do appear in multiphase compositions, it is usually together with phase one.

Another interesting result comes from the study of phase four. In this phase, the elks are related to earlier compositions to a great degree $(74 \%)$. They do appear alone, but in many cases this independence is a result of the composition's limitations. There are no big panels containing just elks from phase four. Instead, they are scattered over the entire island with no particular concentration. As I interpret the statistical results, phase four is the most integrated of all. Of course, one could claim that the reason for the large quota of integrated figures is a lack of space in the last phase. In my opinion, however, this argument is fairly weak. There is still plenty of room for new carvings at Nämforsen, and the figures of phase four could have been placed somewhere else if so desired.

\section{METAPHORICAL CONTENTS OF THE ELK MOTIF}

The result of the interaction study can be discussed from many viewpoints, and raises lots of questions. What is being focused on in this 
paper, however, is the connection between the earliest and the latest phase of Nämforsen. These two types occur together to a large extent and also have visual similarities concerning the short straight legs and the angle of the neck. Even more striking is the resemblance between the elks of phase four and the Mesolithic grounded elks in so-called Nordland style which are found at the sites of Landverk and Gärde not far from Nämforsen (fig. 6). Together with the statistical results, these observations can show that there was a nostalgic or archaizing element connected to the latest phase. As Kjel Knutsson has pointed out, there are also data from the lithic material that support the existence of such a process within the Norrlandic region during the Late Stone Age (Knutson 2005, 2010; Knutson \& Knutson 2009; Glørstad 2002).

The archaizing aspect of the elk motif from phase four is of great symbol-theoretical importance. As these figures come to reveal, the motif being depicted is not necessarily equivalent to what is being mediated through appearance. This is because the elks of phase four are not referring to the actual animals in the landscape so much as they are making associations to the very tradition of depicting such animals. With a subtle formulation one can say that they are images of images, that is, standardized symbols that refer to connotations of the initial image rather than to what this might have represented. The figures from phase four thus remind us about the incompleteness of the mimetic perspective. They let us know that elk figures have metaphorical potential.

Since the elk figures carved in phase four are referring to something other than what they are portraying, they are to be understood as metaphors. A metaphor can be described as a tool for thought, a cognitive implement that makes it possible to express one phenomenon by referring to another (Tilley I 999; Lødøen 2003). As the philosopher Susan Langer has pointed out, a metaphoric mind operates by thinking with, rather than of elements in the life-world. In order to concretise concepts of a non-conceivable nature, we use something visual and material as a tool for thought. By thinking "with" fire we can comprehend the concept of passion, and by thinking "with" clocks and calendars we can manage the abstract concept of time (Langer I954:I30). Hence, the elk motif's metaphorical potential makes it accurate to see it as something that man in prehistory was thinking with in order to grasp conceptual and immaterial aspects that were brought to the fore. This idea would be suitable to explain the huge variation within the motif group. If the elk motif has a metaphorical content, it becomes reasonable to claim 

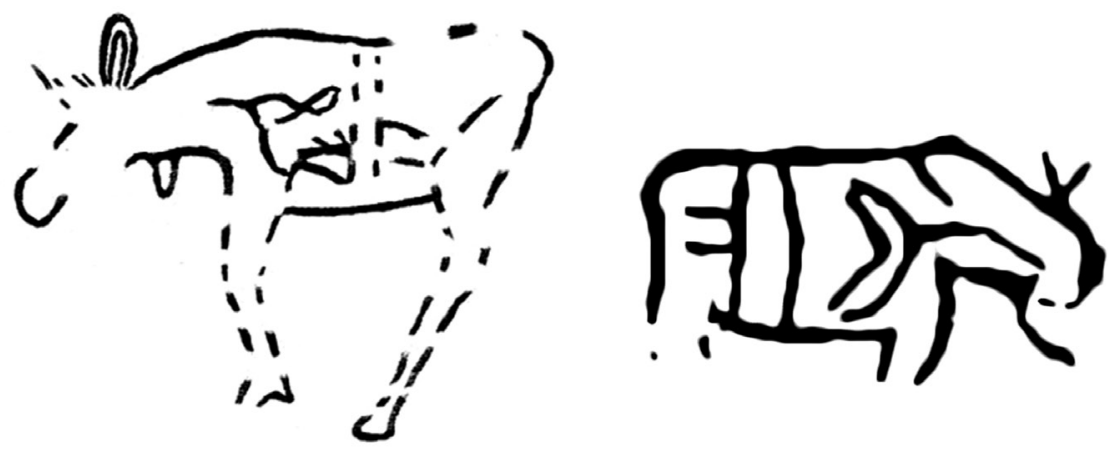

Figure 6. Archaizing? Grounded elk figure from Landverk executed in typical Nordland style and elk figure from Nämforsen deriving from the latest phase. The figure from Landverk is almost in natural size whereas the one from Nämforsen is about $40 \mathrm{~cm}$ high (examples taken from Hallström's documentation I960).

that the variations are significant for different types of concepts. In other words, if the elk is something used to think with, these thoughts are expressed through the alteration of the motif.

If the variations between the elks are held to be significant for different concepts, the interaction between the phases takes on an interesting dimension indeed. When the elks of phase four are placed in close connection to the earliest types, a metaphorical interaction occurs. By relating a new elk to one belonging to the oldest phase, the conceptual dichotomy between convention and improvement might have been manifested. It is, however, important to note that an elk from phase one becomes a metaphor for the abstract concept of "something very old" first when the standardized and archaized elk from phase four is carved next to it. The elk from phase one was made with the intention of mediating one concept, but the symbolic interaction that comes with the accumulative aspect made it mean something else. The elk motif at Nämforsen can therefore be seen as a motif that embodies a lot of concepts which change according to the variations that become visible through the accumulative process.

By studying how figures were placed in relation to others, we can see how the elk motif was used. After that, it might be interesting to investigate if the time for a particular symbolic interaction between the phases corresponds to changes within the material culture. When this approach is carried out, we need to reverse our understanding of the elk motif. Instead of seeing the elk figures as representations, we 
need to see them as metaphors. We must admit their ability to mediate a range of non-conceivable concepts, and also understand that these are supplied through the stylistic diversities as well as the context that comes from the symbolic interaction. Consequently the elk has to be seen as something that man in prehistoric society was thinking with, rather than thinking of. When studying the accumulative aspect of rock art we may be able to reveal how these thoughts were manifested.

\section{CONCLUSION}

In this paper, the accumulative processes of rock art have been analysed. Through a case study of the compositions at Nämforsen in northern Sweden, I discussed the fact that rock art panels contain "pictures in the picture" and accordingly must be studied as productions rather than products. The accumulative aspect of rock art is visible to us by the fact that the same motif has been depicted in different styles. From the position that the images at Nämforsen are metaphors rather than portrayals of reality, I suggested that differences within the motif group reflect differences in meaning. In short, the same motif has been used for expressing a variety of concepts.

The result of the sequence analysis showed that a majority of the compositions defined by Hallström contained figures deriving from more than one phase. This in turn shows that phases have integrated with each other to a large extent. Through statistical studies some patterns concerning the different phases' relation to each other have become apparent. An important result is that the latest phase is connected to the first one, while the third one is carved more autonomously. Based on this information, I claimed that an archaizing process is reflected through the elk motif. The striking similarities between the elks of phase four and the earliest type of elk figures in the Nordland tradition can also support such an explanation.

Taking this archaizing interpretation as a point of departure, the metaphorical aspect of the elk motif could be shown. By pointing out that the elks of phase four are images of the tradition of depicting elks rather than representations of this animal, I claimed that this motif has metaphorical status.

Ylva Sjöstrand, Department of Archaeology and Classical Studies, Stockholm University, I06 9I Stockholm, Sweden 


\section{References}

Bakka, E. I976. Geologically dated rock carvings at hammer near Steinkjaer in Nord Trøndelag. Arkeologiska skrifter Historiskt Museum, Universitetet i Bergen. Vol. 2. Pp. 7-48.

Baudou, E. I993. Hällristningarna vid Nämforsen - datering och kulturmiljö. In: Forsberg, Lars. \& Larsson, Thomas. B. (Eds.) Ekonomi och näringsformer $i$ nordisk bronsålder: rapport från det 6:e nordiska bronsålderssymposiet, Nämforsen I990. Pp. 247-26I. Studia Archaeologica Universitatis Umensis. Vol. 3. Umeå: Umeå University

Baudou, E. 1997. Gustaf Hallström: arkeolog i världskrigens epok. Stockholm: Natur och kultur.

Bradley, R. 2000. An archaeology of natural places. New York: Routledge.

Burenhult, G. 1999. Arkeologi i Norden. Del I. Stockholm: Natur och kultur.

Coles, J. 2004. Illuminations and reflections, looking at Scandinavian rock carvings. In: Heydt, T \& Clegg, J. (Eds). Aesthetics and Rock art and changing stages of consciousness. Pp. I59-I77. Hampshire: Ashgate.

Fandén, A. I995. Den norrländska hällmålningstraditionen. Tolkning av funktion och symbolisk betydelse. Unpublished MA thesis. Department of Archaeology. Stockholm: Stockholm University.

Forsberg, L. I992. De norrländska hällristningarnas sociala kontext: alternativa tolkningar. Arkeologi i norr, Vol. 3. Pp. 5 5-69.

Forsberg, L. 1993. En kronologisk analys av ristningarna vid Nämforsen. In: Forsberg, L. \& Larsson, T. B. (Eds). Ekonomi och näringsformer i nordisk bronsålder: rapport från det 6:e nordiska bronsålderssymposiet, Nämforsen I990. Studia Archaeologica Universitatis Umensis. Vol. 3: Pp I95-246. Umeå: Umeå Universitet.

Gjerde, Jan Magne. 20Io. Rock art and Landscapes. Studies of Stone Age rock art from Northern Fennoscandia. Tromsø: Universitetet i Tromsø

Glørstad, H. 2002. Neolittisk renessanse: hypoarkeologiske tekster om neolitikum i Sørnorge. Acta humaniora, I43. Oslo: Oslo universitete.

Goldhahn, J. 2002. Roaring Rocks: An Audio-Visual Perspective on Hunter-Gatherer Engravings in Northern Sweden and Scandinavia. Norwegian Archaeological Review Vol. 35:I. Pp. 29-6I.

Hagen, A. 1976. Bergkunst: jegerfolkets helleristninger og malninger i norsk steinalder. Oslo: Cappelen.

Hallström, G. I928. N. J. Ekdabls norrländska resor och samlingar I827-I 830 . Härnösand: Arkiv för norrländsk hembygdsforskning I928-ı 929.

Hallström, G. I960. Monumental art of northern Sweden from the stone age: Nämforsen and other localities. Stockholm: Almqvist \& Wiksell.

Hallström, G. 1967. Hällristningarna vid Nämforsen. Svenska fornminnesplatser $\mathrm{Nr} 5$ o. Stockholm: Almqvist \& Wiksell.

Hauptman Wahlgren, K. 2002. Bilder av betydelse. Hällristningar och bronsålderslandskap i nordöstra Östergötland. Göteborg: Bricoleur Press.

Helskog, K. I988. Helleristningene i Alta: spor etter ritualer og dagligliv i Finnmarks forhistorie. Alta: Alta Museum.

Helskog, K. I999. On the shore connection. Cognitive landscape and communication with rock carvings in northernmost Europe. Norwegian Archaeological Review, Vol 32:2. Pp. 73-94. 
Helskog, K. 2000. Changing rock carvings - changing societies? A case from arctic Norway, Adoranten. Vol 2000:I. Pp. 5-I6.

Helskog, K. 2004. Landscapes in rock-art: rock-carving and ritual in the old European North, pp.. In: Chippindale, C. and Nash, G., (eds.). The figured landscape of rock art. 265-288. Cambridge: Cambridge University Press.

Hultkrantz, Å. I989. Hällristningsreligion. In: Jansson, S. Lundberg, E. B. \& Bertilsson, U. (Eds.). Hällristningar och hällmålningar i Sverige. Stockholm: Forum.

Kaleas, L. I990. Rapport från hällristningssymposium. Fornvännen. Vol 85. Pp. I99-20I.

Knutsson, K. 2005 . Bridging the abyss of time. Material culture, cultural reproduction and the sacred time of origin. In: Knutsson, H. (Ed.). Pioneer settlements and colonization processes in the Barents region. Vuollerim Papers in hunter gatherer archaeology Vol I. Pp. I I 7-I 4 I. Vuollerim: Vuollerim 6000 år.

Knutsson, K. 20I0. Arkaisering i norra Fennoskandien under stenålder. Unpublished abstract for the higher seminar in archaeology at Stockholm University the 20 th of January 2010.

Knutsson, H. \& Knutsson, K. 2009. Neolithization as if history mattered in Central Scandinavia. In: Håkon Glørstad. (Ed.). Neolithization as if history mattered. Proceedings of the EAA Annual Meeting in Krakow I9-24 September 2006.

Käck, J. 2009. Samlingsboplatser? En diskussion om människors möten i norr 7000 f. $k r-k r f$ med särskild utgångspunkt $i$ data från Ställverksboplatsen vid Nämforsen. Studia Archaeologica Universitatis Umensis 24. Umeå: Umeå University.

Lahelma, A. 2008. A touch of red: archaeological and ethnographic approaches to interpreting Finnish rock paintings. Dissertation. Iskos I 5. Helsingfors: Suomen muinaismuistoyhdistys.

Langer, S. I957. Philosophy in a new key: a study in the symbolism of reason, rite, and art. Harvard University Press: Cambridge.

Larsson, T. \& Engelmark, R. 2005. Nämforsens ristningar är nu fler än tvåtusen. Populär arkeologi. Vol 2004:4. Pp.I2-I3.

Lindgren, B. 200I. Hällbilder : kosmogoni \& verklighet. In: Bergvall, M. \& George, O. (Eds). Tidsspår: forntidsvärld och gränslöst kulturarv.Pp.43-83. Härnösand: Ångermanlands och Medelpads hembygdsförbund.

Lindqvist, C. I994. Fångstfolkets bilder: en studie av de nordfennoskandiska kustanknutna jägarhällristningarna. Theses and Papers in Archaeology 5. Stockholm: Stockholm University

Lindqvist, C. I999. Nämforsenristningarna: en återspegling av jägarnas liv och världsbild. In: Bergvall, M. \& George, O. (Eds). Tidsspår: forntidsvärld och gränslöst kulturarv. Pp. I05-I I9. Härnösand: Ångermanlands och Medelpads hembygdsförbund.

Lødøen, T. 2003. Late Mesolithic rock art and expressions of ideology. In: Larson, L., H. Kindgren, K. Knutsson, D. Loeffler and A. Åkerlund. (Eds.). Mesolithic on the Move. Pp. 499-507. Oxford: Oxbow Books.

Malmer, M. I98I. A chorological study of North European rock art. Vitterhetshistorie- och antikvitetsakademiens Handlingar 32. Stockholm: Almqvist \& Wiksell International.

Malmer, M. I992. Har nordlig och sydlig hällristningstradition påverkat varandra - och i så fall hur, och varför? Arkeologi i norr. Vol. 3. Pp 7-ı 8.

Myhre, L. 2004. Trialectic archaeology: monuments and space in southwest Norway I700-500 BC. Stavanger: Arkeologisk museum.

Nordbladh, J. I980. Glyfer och rum. Kring hällristningarna i Kville. Gothenburg: Gothenburg University. 
Ortner, S. I973. On key symbols. American Anthropologist. Vol 75:5. Pp. I338I 346 .

Ramqvist, P, Forsberg, L \& Backe, M I98 5. “... and here was an elk too ...” A preliminary report of new petroglyphs at Stornorrfors, Ume River. In: Backe, M. et al. (Eds). In honorem of Evert Baudou. Pp. 3 13-337. Archaeology and Environment 4. Umeå: Umeå University

Ramqvist, P. I988. Boplats och hällristningar i Norrfors, Umeälven. Arkeologi $i$ norr. Vol I. Pp. 29-49.

Ramqvist, P. I992. Hällbilder som utgångspunkt vid tolkningar av jägarsamhället. Arkeologi i norr. Vol 3. Pp. $3 \mathrm{I}-54$.

Rosengren, M. 200I. Grottbilder. Res publica. Vol 53. Pp. I04-I I 5.

Rosengren, M. 2002. Doxologi: en essä om kunskap. Åstorp: Rhetor.

Segerström, U. I98 I. Pollendepositionsanalys i varviga sediment. In: Baudou, E \& Nejati, M. (eds.). Luleälvssymposiet I-3 juni I98I. Pp I3 I-I 36.

Sognnes, K. I999. Det levende berget. Trondheim: Tapir.

Sognnes, K. 200 I. Prehistoricric imagery and landscapes: rock art in Stjørdal, Trøndelag, Norway. Oxford: Archaeopress.

Sjöstrand, Y. 20 Io Should I stay or should I go? On the meaning of variations among mobile and stable elk motifs at Nämforsen, Sweden. In: Goldhahn, J., Jones, A. \& Fuglestvedt. I (Eds). Changing pictures. Rock Art Traditions and Visions in Northern Europe. Pp I39-I 54. Oxford: Oxbow.

Sjöstrand, Y. In press a. Samma motiv - Samma mening? Symbolteoretiska reflektioner angående älgmotivet i den ångermanländska hällkonsten. Article submitted to the anthology from Rödockrarummet conference 25-26 september, Näsåker Sweden.

Sjöstrand, Y. In press b. When seeing is out of sight. On mimetic within rock art research. Article submitted to the anthology from the Nordic TAG Conference 26-29 May 2009, Trondheim, Norway.

Tilley, C. I99 I. Material Culture and Text. The Art of Ambiguity. London: Routledge.

Tilley, C. I999. Metaphor and material culture. Oxford: Blackwell.

Wennstedt Edvinger, B. I993. Genus och djursymbolik: om den norrländska fångstkulturens organisation med avseende på kön. Umeå: Umeå University.

Wriggelsworth, M. 2006. Explorations in social memory - rock art, landscape and the reuse of place. In: Barndon, R. Innselset, S. Kristoffersen, K. \& Lodoen, T. (Eds). Samfunn, symboler og identitet - Festskrift till Gro Mandt på 70 års dagen. UBAS 3 . Bergen: Bergen University. 
REVIEWS \& NOTICES 
Åsa M. Larsson

Breaking and Making Bodies and Pots: Material and Ritual Practices in Sweden in the Third Millennium BC

Aun 40

Uppsala: Uppsala University 2009

493 pages

ISBN 978-91-506-2092-4

Kim von Hackwitz

Längs med Hjälmarens stränder och förbi - relationen mellan den gropkeramiska kulturen och båtyxekulturen

Stockholm Studies in Archaeology 51

Stockholm: Stockholm University 2009.

275 pages

ISBN 978-91-978257-3-3

Review by Björn Nilsson

During 2009 not less than three doctoral dissertations explored the Swedish Middle Neolithic. Two of these research efforts are reviewed in the following. Åsa M. Larsson's and Kim von Hackwitz's books encompass the same theme: the relationship between the so-called Pitted Ware culture and the Battle (or Boat) Axe culture. The two projects are very different in their premises, their research methods, and their conclusions.

Larsson's dissertation is a large and great work. The approach is both theoretical and empirical, and might be a bit demanding even for an archaeologist whose main focus lies outside the Scandinavian archaeology of the Middle Neolithic. Since the work is a dissertation this should not be considered a problem. And since the writing style is very 
good, sometimes in a journalistic manner, even the most elaborate technical discussions are quite easy to follow. In order to understand - or explain - the relationship between the Pitted Ware and the Battle Axe culture, the thesis deals with several archaeological and anthropological super-themes: technical change and (material) cultural diversity, the relationship between the social and the technical, between nature and culture, body and being, everyday practices and occasional rituals. The field is vast, but since Larsson focuses on pottery and mortuary practices, the scope becomes sustainable throughout the book, which is divided into five parts.

Part I positions the work and its premises, and after a short introduction to archaeological and anthropological theories of culture and change Larsson outlines a socio-technological theoretical approach that is focused on embodied experience and cognition, and influenced by both phenomenology and practice theory. Furthermore, Larsson reclaims an anthropological archaeology as a study of the "real everyday life". Part II presents the late Middle Neolithic (MNB) in Scandinavia and its research history. Larsson concentrates mainly on pottery traditions, and offers insights into the archaeological use of style and typology. Part III is entitled "Living Bodies" and spotlights the actual making of material culture. Craft and tradition are viewed through both anthropological and archaeological lenses. The outline is straightforward, down-to-earth and empirically distinct. Larsson reveals differences between Pitted Ware pottery and Battle Axe beakers. Regarding the latter Larsson stipulates that the Battle Axe pottery is novel and suggests that the new elements must be due to a relocation of potters. By means of style and technique Larsson proposes that the Battle Axe pottery was introduced into eastern middle Sweden by a group of Middle Neolithic people from the area of south-east Finland. Larsson defies the conclusion that a completely new population would have settled in eastern Sweden. The local continuity in stone craft, certain uses of raw material, and patterns in the use and re-use of the landscape all suggest that the pottery tradition descends from a small and distinct relocated group of people, most likely a result of interregional exogamic relations. The argument for cultural distinction between the Pitted Ware and the Battle Axe culture is reinforced in the following part which is devoted to the "Dead Bodies". Here Larsson's osteo-archaeological skill is evident, and through the examination of the Bollbacken (Pitted Ware) 
and Turinge (Battle Axe) mortuary houses, and the bodily remains on the two sites, more arguments for a cultural-dualistic interpretation of the Middle Neolithic of Sweden are put forth. The last and fifth part synthesizes everything: the reader is almost forced to be convinced by Larsson's logical reasoning, the detailed yet universal study and empirical penetrations, and the writings of a truly devoted researcher.

von Hackwitz's study is not as large as Larsson's, which by no means should be seen as a disadvantage. On the contrary, von Hackwitz's dissertation is quite exemplary in extent and scope. The focus is on the relationship between the Pitted Ware culture and the Boat Axe culture. The approach is somewhat more local; the geographical research area is $6800 \mathrm{~km}^{2}$ and covers the prehistoric Lake Hjälmaren and part of the Littorina coast and sea. von Hackwitz declares in the first sentence that her thesis is about "humans and landscape, history and interactions, material culture and change". Pretentious keywords, of course, but I think von Hackwitz is serious - and interesting - in the sense that she enters the Pitted Ware/Battle Axe minefield with the intentions of writing landscape and settlement archaeology, rather than getting stuck in revisions of archeological ordering of the Middle Neolithic material culture. It is brave, and already after some 20 pages von Hackwitz announces that her main goal is to fight down Middle Neolithic cultural dualism. Throughout the thesis von Hackwitz uses the concepts of Pitted Ware and Battle Axe as two different sets of material culture, proactively used by the Middle Neolithic people in the Hjälmaren area. She comes to the conclusion that the Pitted Ware sites are of a ritual character, anchored in their past. The Battle Axe sites are found on Early Neolithic settlements and along landscape routes. The Battle Axe material culture is thus interpreted as the remains of an internally emerging social group, formed by travels and long-distance alliances. Von Hackwitz's study uses data predominately extracted from site and stray-find registers in the archives of the Museum of National Antiquities (SHM), and digital data from the national survey of heritage sites (FMIS). Basic GIS-operations are made, such as viewshed analyses and coastline manipulations. Accordingly, the approach in the three main case studies is rather distanced from the material. This detachment is not a problem per se; rather, it is unavoidable in general landscape or settlement studies. The problem arises if the researcher treats the national data from the FMIS databases or SHM collections as a true pre- 
historic representation, instead of as the complex and messy antiquarian record it really is. von Hackwitz's study suffers from this, which has led to an incoherent dataset with a handful of minor and some major errors. Even though the main results withstand these faults, it is annoying. The data could easily be corrected and published in an abbreviated version. Until then it is a bit difficult to use the thesis. And that is a disappointment, since the ideas - and results - are of great interest.

The two books are dissimilar in many ways. Larsson's work is a major effort and is meticulously done. Her interest in the making and altering of material culture, in technological practices, and detailed empirical studies of archaeological objects provides a basis for her to prove that the dissimilarities between the Pitted Ware and the Battle Axe culture are a result of internal change and contact between other people. von Hackwitz's work is a bit clunky, yet tantalizing. In her Middle Neolithic landscape another cultural history is told. Here the different material cultures were actively used to mark differences internally. On the other hand both studies are similar. Each connects the Pitted Ware culture with tradition, and the Battle Axe culture with the new and the geographically distant. They both use the conventional definitions or categorizations of Middle Neolithic archaeology. I suppose that is necessary in this vast field of research, but as times goes by, archeological suggestions have grown into prehistoric facts. After a while it is hard to detect circular reasoning. One must not forget that the relation between the Pitted Ware and the Battle Axe culture during the Middle Neolithic is something totally anachronistic - a complex archeological composition of scientific aims and wishes, and some inviting material remains. 
Magnus Alkarp

Det gamla Uppsala. Berättelser \& metamorfoser kring en alldeles särskild plats.

OPIA 49

Uppsala: Uppsala University 2009

ISBN 978-91-506-2095-5

Review by Anna Lihammer

Old Uppsala is not just an important ancient heritage site. It is also a place that has had central importance in myths and legends of more recent times - in research and local history as well as in darker contexts such as nationalism and Nazism. For centuries it was the national monument of Sweden and the ancient Swedes, thereby constituting a national symbol. But like many other national monuments, the site of Old Uppsala has also become somewhat of a monolith where archaeological research and knowledge are concerned. The image of Old Uppsala has in many ways existed outside and parallel to other research. For example, although archaeological research of the last 50 years clearly contradicts early formation of the kingdom of Sweden and the existence of powerful "Svea" kings in the Iron Age, there are no signs that the general image of Old Uppsala has changed profoundly.

Magnus Alkarp's PhD thesis, Det Gamla Uppsala. Berättelser \& Metamorfoser kring en alldeles särskild plats ("The Old Uppsala. Narratives and metamorphoses concerning a very special place", my translation) tries to reach behind all the myths, legends, theories and practices that have concerned and affected the image of Old Uppsala. The purpose of the thesis is to investigate how this image has been formed and changed during different eras, to follow the theories and discussions about Old Uppsala and place them within their historical and contemporary contexts. Deconstructions and the identification of er- 
rors are therefore not the focus, but rather a quest to understand how different ideas have originated and developed and exactly what in the archaeological material has given them legitimacy. In short, why does the present image of Old Uppsala look as it does?

Alkarp's investigation focuses on two periods, one that starts with the I 7 th century and lasts until the beginning of the I 8 th century, and the other a period from the beginning of the I 9 th century and into the middle of the 2oth century. The thesis consists of 457 pages and is divided into an introductory part, a number of chapters on Old Uppsala arranged chronologically, and a concluding part. The book is well composed, but some additional orientation at the start would have helped.

The changing image of Old Uppsala is followed through an impressive amount of written sources, the making of history, detailed biographies of its interpreters, and occasionally also the development of the archaeological material from the site. It is an interesting and intriguing approach, and one that should be applied to many other monumental heritage sites. The vivid language and detailed descriptions of individuals make the thesis easy and pleasurable to read, but occasionally also create question marks in the mind of the academic reader. Sometimes it is hard to find the references for Alkarp's descriptions of what these people really thought and felt. I have no doubt that Alkarp knows his sources and has evidence for what he has written, but the scientific reader who would like to evaluate this material sometimes finds this difficult.

One of the studied eras includes the decades before and during the Second World War and the clearly nationalistic approach to Old Uppsala (and a number of other monuments) that developed during those years. During the last two decades, a debate has been going on concerning the relations between Swedish archaeological scientists and Nazi Germany before and during the war. One side has claimed that most of the famous Swedish archaeologists (and Swedish archaeology at large) were Nazi friendly or even convinced Nazis during these years, and another side has taken a completely opposite approach claiming there was almost no Nazism at all in Swedish archaeology, but a nationalism that can be explained by the wartime context rather than by Nazism or racism (cf. Welinder I990, 1994; Werbart I999, 2000; Baudou 2000, 2001).

Though Alkarp's thesis concerns Old Uppsala rather than the wider Swedish context in general, the part in it that analyses the 2oth century obviously relates to this debate and most clearly since Alkarp dis- 
cusses the role and actions of Sune Lindqvist, a central figure in the debate, in more detail than anyone else before. Alkarp's admirable research on Lindqvist, drawing on a range of previously more or less unknown sources, is a centerpiece of the part of the thesis that concerns the 2oth century and seems to prove beyond doubt that Lindqvist was not inclined to co-operate with the Nazis but rather the opposite. While presenting a lot of new evidence and while proving Lindqvist was not a Nazi, the book still leaves some questions unanswered. For example, if he had no sympathies for Nazism, why did Lindqvist lecture in the Manhem organization and write in the Germanen-Erbe periodical? As always, a profound analysis such as Alkarp's opens up for further questions.

The overall Swedish debate on the I930s and I940s has hitherto focused on what relations Swedish archaeologists had or did not have with Nazi Germany, but this question should rather be seen against a much wider background of nationalism and racism in archaeology during the period from around $\mathrm{I} 900$ and up to the war, which still lacks a profound overall treatment. Swedish archaeology in general was deeply infested with these ideologies, which started long before the Nazi party came to power, and as the case of Lindqvist exemplifies it was not directly related to Nazism at all. That wider context should be the central object of study and debate, rather than the interesting but non-central questions of whether specific individuals had Nazi sympathies or not. Alkarp does a good job clarifying the situation concerning many of the brown connections, and could not have done more within his frame of study. But there are still many blanks to fill in concerning the bigger picture.

To conclude, Alkarp has made an important, profound and very interesting contribution to the understanding of Old Uppsala and a large number of its interpreters and their wider contexts. More national monuments should be treated in this way. The new information on early 2oth-century archaeology, and on Sune Lindqvist and the I930s and 4 os Uppsala seminar more specifically, is important and will be of great value for future research and debates. Many questions remain and Alkarp's work raises new ones, which is a very positive thing to say about a dissertation. 


\section{References}

Baudou, E. 2000. Nationalismen i den svenska arkeologin under I900-talet. Fornvännen 95 . Pp. 35-42.

Baudou, E. 200I. Svar till Bozena Werbart angående nationalismen i den svenska arkeologin under I900-talet. Fornvännen 96. Pp. 35-38.

Welinder, S. I994. Svensk arkeologis protorasistiska föreställningssediment. Tor 26. Uppsala: Uppsala universitet.

Werbart, B. I999. Archaeology yesterday and today: Sweden I930-1945. In: Gustafsson, A. \& Karlsson, H. (Eds). Glyfer och arkeologiska rum - en vänbok till Jarl Nordbladh. Gotarc, serie A, Vol. 3. Göteborg: Institutionen för arkeologi, Göteborgs universitet.

Werbart, B. 2000. Svar till Evert Baudou angående nationalismen i den svenska arkeologin under I900-talet. Fornvännen 95. Pp. 25 I-255. 
Stig Welinder

Sveriges historia 13000 f $\mathrm{Kr}-600$ e $\mathrm{Kr}$

Stockholm: Norstedts 2009

502 pages

ISBN 978-91-1-302376-2

\section{Dick Harrison}

Sveriges historia 600-1350

Stockholm: Norstedts 2009

502 pages

ISBN 978-91-1-302377-9

Review by Susanne Thedéen

Almost 50 years have passed since the prehistory and history of Sweden were last written and presented for the public. Last autumn the first two of a total of eight volumes of a new edition of the history of Sweden were published. The main editor is Professor Dick Harrison who is also the author of the second volume covering the period from AD 600 to I3 50 . The author of the first volume is Professor Stig Welinder who has taken on the challenge of writing the history of Sweden from the very beginning around $\mathrm{I} 3000 \mathrm{BC}$ to $\mathrm{AD} 600$. Both volumes are ambitious and impressive works written within very limited time frames. Crucial issues within humanities debated over the last 50 years are covered. The main focus in both volumes is social perspectives including questions related to cultural identity and social structure. Further, issues of significance in our contemporary society such as war and conflict, the important role of food, the relation between humans and animals, ritual aspects of the life and death of humans, and contacts and travels are covered.

Readers are introduced to two very different tales. Welinder con- 
structs his narrative with a bottom-up approach using small tales, often very detailed ones. Readers are served several explanations and interpretations of prehistoric life and death, but syntheses are to a large extent absent. Welinder has written a history of his own, emphasizing issues of interest to him, perhaps provocative in some parts but overall delivered with enthusiasm. He discusses his thoughts, doubts and problems in a personal way and maintains a constant dialogue with readers. In contrast, Harrison uses a top-down approach that emphasizes broad perspectives such as the formation of the state, the struggle for power between leading families, and the growth of the church as a major impetus for societal change. Harrison is the great storyteller, presenting the big picture clearly and arguing as an experienced scholar and a professor of deep knowledge.

The disposition in Volume II is straightforward, quite pedagogical and easy to follow. On the other hand Welinder, in Volume I, moves between various time periods, although there is an underlying chronology. This may very likely confuse readers especially as he has chosen not to use the traditional chronological framework. Unfortunately the headings do not provide much help. Instead they sometimes appear to be cynical, for example "The light people with the light metal" and "Aryans", which take into account the significant discussions of cultural identity in the text. Both volumes are richly illustrated. The beginning of Volume II suffers, however, from a narrow choice of illustrations where rune stones and churches are heavily over-represented. A greater number and wider variety of illustrations of archaeological sites, architecture and material culture in general would have been a contribution to Volume II.

An additional remark on Volume II is that only I 30 out of 500 pages are devoted to the period $\mathrm{AD} 600-\mathrm{I000}$, and moreover the entire period $\mathrm{AD} 600-\mathrm{I000}$ is in general discussed with written source material as the point of departure and main source. Archaeological sources only serve as backgrounds and are foremost used to confirm the written sources. This becomes clear when Harrison uses a patronizing tone and choice of words to imply that archaeology is of less value than historical sources. On several occasions he returns to the use of the word "guesses" in relation to archaeological interpretations. A disappointment with Volume II is that it does not take advantage of all the archaeological excavations of the last 40 years. Consequently, important results of foremost settlement archaeology but also burial practices as well as 
ritual and symbolic approaches are overlooked and neglected. Readers are provided with the obvious archaeological sites such as Birka and Uppåkra as well as famous burial grounds such as Valsgärde and Old Uppsala. In Volume I, Welinder clearly shows that archaeology has a great deal to tell about people and societies and worldviews in prehistory. Therefore it is strange that Harrison in Volume II has so little to say about a time that is so much closer to ours than the very remote past in Volume I. This reflects weak knowledge of and lack of concern for the archaeology of the Iron Age. Overall it was not the best choice to make $\mathrm{AD} 600$ the break point between the two volumes. Welinder and Harrison are two very qualified writers but their main interest and knowledge is not in a narrative of the Scandinavian Iron Age and Viking Age. A better solution would have been to have a further volume covering the first millennia $\mathrm{AD}$, preferably written by someone with archaeological knowledge of the period.

Welinder is known to have initiated gender issues within archaeology in Sweden. It is therefore a surprise that we are told such a traditional story of gender roles in Volume I. Even when there are good occasions for it, the opportunity is not taken to suggest interesting gender interpretations. This is most obvious in relation to discussions of women and female gender roles. However, the author has all the more to tell about children in the past, which is an important contribution. Children are present on as many as 50 pages. In Volume II the lives and roles of children in society are invisible. Already the headings are very worrying and revealing for a reader who is interested in gender perspectives throughout history. The headings comprise to a large extent identities and phenomena with associations to male words and worlds such as chieftain, ruler, lords, kings, war and plundering, monks, knights and crusaders. Women appear occasionally but more as "addand-stir" or stereotypes. The possibility of third genders or queer perspectives does not appear in the main texts but is touched upon in an article by a historian of religion.

All in all Welinder has succeeded in writing many small, non-linked, but new narratives of Swedish prehistory, while Harrison has written an impressive synthesis in which power is the main explanation for various phenomena but which is surprisingly conventional and has few new interpretations. Of course both volumes should be read by anyone interested in the history of Sweden, but if you have to choose only one I would certainly recommend Volume I. 
History of Sweden

Thursday 27 May 20 Io marked the occasion of the opening of the exhibition "History of Sweden" by H.M. King Carl XVI Gustaf in the presence of H.M. Queen Silvia at the National Historical Museum in Stockholm.

The exhibition covers rooo years of Sweden's history, from around $\mathrm{AD}$ I 000 to the present time. It is one of the largest and most ambitious exhibition-projects undertaken at the museum in modern times. Chronologically structured and covering some $600 \mathrm{~m}^{2}$, the exhibition starts with a prologue and is divided into ten "scenes", each representing a century. It ends with an epilogue reflecting on present-time developments and on history as a continuous process.

On a meta-level "History of Sweden" tells the story of the "realm", which becomes the "state", which becomes the "nation", which is now part of a "union". A fluorescent time-line in the floor projects the flow of time throughout the exhibition and gives information on Sweden's rulers. It also connects Sweden's history to important international events. The selection of objects in the exhibition has been strict, resulting in a selection of about 350 carefully curated objects. With a few notable exceptions, most objects are from the collections of the $\mathrm{Na}$ tional Historical Museum.

The main purpose of the exhibition is to give an informative, coherent, accessible and exciting introduction to Sweden's history for a wide audience of domestic and international visitors. Due to the fact that Sweden's various National Museums to a significant extent are founded and structured around the traditional academic disciplines (i.e. art history, ethnology, archaeology, etc.) such an exposition has been lacking in modern times, and has frequently been requested by many visitors to the National Historical Museum.

In the production of the exhibition, special attention has been given to developing interactivity and to providing an experience for all senses. 
An additional aim has been to present an updated view on Sweden's history from a scholarly perspective, thus incorporating gender and class as well as devoting attention to what is sometimes referred to as marginalized groups. Addressing difficult issues and events in Swedish history has also been an integral part of the project.

Building on the need for positive visitor-experiences, dramaturgy is a key element of the exhibition, allowing for intense and dramatic narratives as well as quieter presentations in a thought-out manner.

Communicating the exhibition, the National Historical Museum has co-operated with the media corporation $\mathrm{TV}_{4}$-Gruppen and with the publishing house Norstedts Förlag, the former viewing a series of I I television programs called "Sveriges historia" (History of Sweden) during 2OIO-I I and the latter producing a series of eight volumes with the same name: "Sveriges historia" (History of Sweden). The co-operation has mainly had a communication and marketing focus with a view to reaching new audiences and to collectively support each other to penetrate through the "media buzz".

An exhibition like "History of Sweden" should be considered a process rather than a product. The idea is that the exhibition will function as a platform onto which programming activities, guided tours, special events, written material, etc. will be added.

The use of new social media has been built into the concept from the outset with the double aim of increasing awareness and creating a dialogue with visitors and potential visitors. Thus, an exhibition blog http://blogg.historiska.se/sverigeshistoria (only in Swedish) has been set up, accessible through the website www.historiska.se of the National Historical Museum. A twitter-feed (\#svehist) has also been set up, where questions and comments may be posted and which the staff at the Museum (@Historiska), including myself (@LarsAmreus), regularly follow. Communication also takes place through Facebook accounts such as "Historiska Museet", "The National Historical Museum” and "Kvinnan Från Bäckaskog”. 
A comment on recent trends in the prerequisites for Swedish development-led archaeology

In sports there is a firmly rooted saying that you do not change the organization of a winning team. In my view Swedish development-led archaeology - for many years organized in mutual understanding and collaboration among the National Heritage Board, county museums, county administrative boards, university departments, and foundations and private corporations - can be described as such a winning team. This is in the sense that open and creative attitudes towards collegial collaboration and a consequent testing and application of new theoretical perspectives and excavation methods steadily improved our knowledge about the past. During the years I $985-2005$ approximately $70 \%$ of the doctoral dissertations published by archaeological departments at Swedish universities dealt in some way with the presentation and further analysis of material that was produced within development-led archaeology. More than $65 \%$ of the dissertations were actually produced by the excavating archaeologists themselves. During this period the archaeological research arena in the traditional university environment was expanded to include archaeologists at museums and the $\mathrm{Na}-$ tional Heritage Board. The expansion was fruitful, and in retrospect we can conclude that it largely improved not only our knowledge but also the quality of Swedish archaeology as a discipline. Academic borders between archaeologists employed at museums and in universities were slowly erased. The number of research projects grew steadily, and hence the awareness of the importance of archaeology increased in the surrounding society. A variety of theoretical approaches were used and projects were often multidisciplinary both in perspective and organization. At the same time an older and in many ways national perspective that long had governed Swedish archaeology became of less importance. Projects were implemented and carried out, fundamentally changing our knowledge of everything from past settlement patterns 
to burial traditions and human living conditions in different periods as well as regions. The increased international collaboration made the Swedish region part of European prehistory in a wider sense. Far-reaching collaborative projects between scientists at museums, the National Heritage Board and university departments ensured the survival of a creative and innovative scientific milieu for research.

During the last five or six years the possibility to maintain high scientific quality in development-led archaeology has, in my view, altered drastically in Sweden. The recent changes in this archaeology have nothing to do with the establishment of any new theoretical paradigms or excavation techniques. The way in which the legislation concerning development-led archaeology is now being applied and regulated, mainly through the formulation of new formal guidelines from the National Heritage Board concerning the conditions for this archaeology, has resulted in a situation where ancient monuments are more and more being regarded as commercial commodities rather than as potential sources of new knowledge. Instead of a further natural increase in collaboration, archaeological institutions that deal with development-led archaeology are now expected to compete with each other in order to be assigned a certain developer-funded excavation project. A natural consequence of this competition is, of course, that almost all collaborations between institutions, and hence also between scientists, has ceased to exist. The new situation has ultimately created a fundamental paradox; of course it is reasonable to assume that the purpose of these far-reaching changes in the application of the legislation concerning development-led archaeology was to increase archaeological knowledge and to decrease the archaeological costs for the developers and for society at large. But at least in retrospect of the last five years, it is clear that the situation has instead become the opposite, which is quite alarming. Archaeologists at museums, in private corporations, and at the National Heritage Board no longer collaborate. Instead we compete with each other for the assignment to carry out a certain excavation project, and though the new regulations have been in "operation" for only a couple of years, it is reasonable to conclude that this development will result in a very distinct decrease and fragmentation in the production of archaeological research and ultimately in the general knowledge about the past. In several geographical regions the competition has led to a concrete decrease in costs for 
archaeological excavation; this is definitely true. But one can seriously doubt that a "cheaper archaeology" will prove to be economical in a longer perspective from any other perspective than the developers'. It is quite obvious that the economical competition has created a situation where less and less time and funds are spent on the analysis of the results from the development-led archaeological excavations. It is also clear that the time and costs spent on the actual field excavations have decreased in many aspects and regions. As a consequence of the competition, the number of multidisciplinary projects and collaborations between institutions has naturally decreased as well.

Since 2005 , approximately 2I \% of the archaeologists that held positions at county museums and the National Heritage Board's department for excavation have lost their jobs. Presumably for economic reasons, steady employment has been transformed into project- or seasonal employment, thus creating a feeling of social uncertainty within the group of archaeologists and scientists. A direct effect of this social uncertainty is that much important research can no longer be produced. It is already evident that the new policy, where archaeologists are supposed to move around in the country in search for jobs, is quite fatal in relation to a more qualitative goal when it comes to the production of vital archaeological knowledge. I can also conclude that the possibility to carry out research within the institutions that deal with development-led archaeology has become limited in the academic and analytical sense as well as the economical. This negative development will, of course, in the end lead to a situation where the universities find there is no flow of new archaeological material and archaeologists from the museums into their departments. The employment possibilities will become rare. Ultimately I fear that this will lead to a situation where archaeology as an academic discipline will attract young students to a much lesser extent than before.

Tore Artelius Chairman of the Swedish Archaeological Society (2006-20I0) 
MARK, the professional association of museum archaeologists, and a little about contract archaeology in company form

January 2009 saw the establishment of MARK, the first professional Swedish organization in development-led archaeology. Unlike the Swedish Archaeological Society or MUSARK, membership is open only to organizations, not individuals. In this respect MARK is a pioneer not just in archaeology but also in Swedish heritage management as a whole.

The museums have a special responsibility for ensuring the provision of local and regional knowledge and communicating the results to the community. Through their public archives and collections, the museums have openness, continuity, and a genuinely long-term perspective that is usually lacking in commercial operations. At the same time, the link to a municipality, a county, or a region involves a limitation of the market that other actors do not suffer from. The conditions for the museums' development-led archaeology, and the underlying ideology, therefore differ from that of other actors.

The aim of MARK is to stimulate interaction and cooperation, thereby creating the conditions for long-term sustainability and development in operations. Through cooperation MARK seeks to further the development of the contract archaeology that is pursued in or close to local and regional museum institutions in Sweden. This cooperation can comprise, for example, research, education, public work, and strategic analysis.

A concrete effect of the network that has been built up between the members of MARK is that it is more common now to bring in subconsultants or experts from other museums in connection with major excavation projects. Another trend that is steadily increasing is that the museums' contract activities are being done in company form. In 20I0, for example, the Regional Museum in Kristianstad started a wholly owned subsidiary, Sydsvensk Arkeologi AB, at the same time 
as it took over Malmö Museums' development-led archaeology. In a time of increasing competition and a shrinking market, there will be more amalgamations, and we will see constellations that no one could have envisaged.

Erik Rosengren Member of MARK Executive Board www.m-ark.se 